\title{
ANÁLISE DE GESTÃO LOCAL E ESTADUAL \\ DOS SERVIÇOS DE ÁGUA E ESGOTO \\ NO ESTADO DE SÃO PAULO, 1996 - 2000
}

Rita de Cássia Ogera

Tese apresentada ao Departamento de Saúde Ambiental da Faculdade de Saúde Pública da Universidade de São Paulo para obtenção do Título de Doutor em Saúde Pública.

Área de Concentração: Saúde Ambiental

Orientador: Prof. Dr. Arlindo Philippi Jr 
Autorizo, exclusivamente para fins acadêmicos e científicos, a reprodução total ou parcial desta tese, por processos fotocopiadores.

Assinatura:

Data: 
Meus sinceros agradecimentos,

Ao Profo Dr. Arlindo Philippi Jr, pelos ensinamentos, paciência e a confiança em mim depositada para o desenvolvimento deste trabalho.

Aos Professores Dr. Marcelo de Andrade Roméro, Dra Maria Cecília Focesi Pelicioni e à Dra Gilda Collet Bruna, que colaboraram profundamente para a consecução deste trabalho.

Ao Profo Dr. Antônio Carlos Gil e ao Dr. Herval Pina Ribeiro, que com tanta simpatia colaboraram com seus ensinamentos e reflexões.

Aos membros da banca examinadora, Professores Arlindo Philippi Jr, Nelson Nucci, Bruno Coraucci Filho, Pedro Caetano Mancuso, Marcelo de Andrade Romero, Sabetai Calderoni e Tadeu Fabrício Malheiros, que contribuíram com sugestões importantes para a melhoria deste trabalho.

Aos profissionais da SEMASA, da SANASA, das Prefeituras de Santos, São José dos Campos, Santo André e Campinas, da SABESP de São Paulo, Santos e São José dos Campos, que contribuíram com informações imprescindíveis para a realização da tese.

À Secretaria Municipal do Meio Ambiente, na pessoa de Stela Goldenstein, pela oportunidade que me foi dada de concluir a pesquisa na Faculdade de Saúde Pública.

Ao Profo Dr. Carlos Celso do Amaral e Silva, pelo pronto apoio ao desenvolvimento deste projeto e pela receptividade no Departamento de Saúde Ambiental.

As bibliotecárias da Faculdade de Saúde Pública, Sueli Campos e Vanda Gabin, que sempre estiveram prontas para o auxílio à pesquisa.

Ao Núcleo de Informações em Saúde Ambiental - NISAM, pelo apoio prestado para a consecução deste trabalho.

À psicóloga Silvia Deschamps, que me auxiliou em muitas horas difíceis desta jornada. 
Ao Professor José de Ávila Coimbra, pelas suas sábias palavras e pela pessoa encantadora, marcando presença em horas tão oportunas.

À Suely Gêiser, Áurea Okuma, Claudia Kohler e Vera Petillo, que foram meu porto seguro na reta final desta largada, momento tão delicado!!.

Aos amigos que, de forma direta ou indireta, contribuíram para a realização deste trabalho, em especial: Ivan Maglio, Regina Luisa de Barros, Solange Redolfi, Cintia Philippi Salles, Mary Lobas, Karla Cardoso de Mello, André Alcântara, Domingos Leôncio, Antônio Mário Reis, Valeska Zenga, Virgínia Tristão, Maria Cristina Hadad, Ana Maria Hoffman, Giuliano Marcon, Katia Simões Parente, Tamy Kato, Lisardo Osório e Marcelene Evangelista.

Agradeço,

Acima de tudo, a Deus, que sempre esteve presente em minha vida, Aos meus pais e irmãos, a quem amo muito. 


\section{Resumo}

Ogera RC. Análise de gestão local e estadual dos serviços de água e esgoto no Estado de São Paulo, 1996-2000. São Paulo; 2002. [Tese de Doutorado - Faculdade de Saúde Pública da USP].

A deficiência de saneamento básico no Brasil está entre os seus cinco maiores problemas de poluição. Tais problemas concentram-se principalmente nas regiões Norte, Nordeste e Centro-Oeste. Embora as regiões Sul e Sudeste do Brasil apresentem melhores condições em relação ao abastecimento de água e ao esgotamento sanitário, o índice de tratamento de esgotos é baixo em vários municípios. Desde a extinção do PLANASA, o Brasil não conta com políticas públicas nacionais para o saneamento básico, o que leva estados e municípios a políticas públicas próprias. Daí o desafio em analisar a gestão dos serviços de água e esgoto em alguns municípios de grande porte do Estado de São Paulo, no período de 1996 a 2000. Os municípios selecionados foram: Campinas, Santo André, São José dos Campos e Santos. Nos Municípios de Campinas e Santo André, a gestão desses serviços encontra-se na esfera de governo municipal. Já nos Municípios de São José dos Campos e Santos, a gestão encontra-se na esfera de governo estadual. Parte-se da hipótese de que há diferenças na eficiência e na eficácia da gestão desses serviços, no que se refere a esferas de governo, estadual ou municipal e, na existência de políticas públicas e de governo. Os métodos adotados para comprovar a hipótese desta tese foram: pesquisa bibliográfica, documental, aplicação de questionários, investigação explicativa fundamentada pela teoria, seguida de análise dos resultados. Políticas públicas e políticas de governo foram tomadas como parâmetros para analisar as diferenças na eficiência e na eficácia da gestão desses serviços. Entre as diferenças na eficiência e na eficácia da gestão municipal e estadual têm-se que: a gestão municipal mostrou-se eficiente nos aspectos analisados em relação a água e esgoto. Essa mesma gestão municipal mostrou-se eficaz nos aspectos analisados em relação a água porém, ineficaz no aspecto esgoto no que se refere ao índice de tratamento. A gestão estadual mostrou-se eficiente nos aspectos analisados em relação a água e esgoto, à medida em que, os partidos políticos do órgão gestor do município e do órgão gestor desses serviços compartilham com as mesmas questões ideológicas.

Descritores: Gestão do Saneamento básico. Gestão pública. Gestão públicaprivada. Políticas públicas. Políticas de governo. 


\section{Summary}

OGERA, R.C. Análise de gestão local e estadual dos serviços de água e esgoto no Estado de São Paulo, 1996-2000. [Analysis of city and state management of water and sewage services in São Paulo State, 1996-2000. São Paulo, (BR); 2002. [Tese de Doutorado - Faculdade de Saúde Pública da Universidade de São Paulo].

Deficiencies in basic public sanitation in Brazil count as one of the nation's major five pollution problems. They concentrate mainly in North, Northeast and Center-West areas. Though South and Southeast areas live under better conditions regarding water supply and sewage sanitation, the sewage treatment index is still poor in many cities. Since PLANASA's extinction, Brazil has been deprived from public national policies for basic sanitation. This forces States and cities to define their own policies. Therefore, the challenge of analyzing water and sewage management services in some big cities from São Paulo State, for the 1996-2000 period. To this end Campinas, Santo André, São José dos Campos, and Santos were the chosen cities. In Campinas and Santo André, the services management is local. As for São José dos Campos and Santos, the administration belongs to State level. Differences in efficiency and effectiveness of the administration of these services are supposed to happen when State or local government levels are compared, as well as when public and government policies are proposed. To probe this hypothesis a few methods were employed, namely, bibliographic and documental researches, question forms to be filled, investigation and explanatory based on theory, followed by a results analysis. Public policies and government policies were taken as parameters to analyze differences in the efficiency and effectiveness of the services management. Regarding the differences in efficiency and effectiveness between local and State managements, it can be said that the city approach to water and sewage treatments administration showed to be efficient as far as the analyzed aspects are concerned. The same city administration showed to be effective regarding the water aspects analyzed, although it proved to be ineffective as far as the sewage treatment index was concerned. The State management proved to be efficient about the water and sewage aspects analyzed, since the political parties of the local administration agency and of the administration agency of the water and sewage services share the same ideological views.

Key terms: Basic sanitation management. Public management. Public-private management. Public policies. Government policies. 


\section{Lista de Abreviaturas}

ABS - ASFA-Aquatic Science \& Fisheries

AGEM - Agência Metropolitana da Baixada Santista

APM - Área de Proteção Ambiental

ASSEMAE - Associação Nacional dos Serviços Municipais de Saneamento

BNDES - Banco Nacional de Desenvolvimento Social

BNH - Banco Nacional de Habitação

BOOT - Build, Operate, Own, Transfer

BOT - Build, Operate, Transfer

CASAN - Companhia Catarinense de Águas e Saneamento

CEF - Caixa Econômica Federal

CEPAM - Fundação Prefeito Faria Lima

CESB - Companhias Estaduais de Saneamento Básico

CETESB - Companhia de Tecnologia de Saneamento Ambiental

CNS - Conferência Nacional de Saneamento

COMASP -Companhia Metropolitana de Água de São Paulo

CONDESB - Conselho de Desenvolvimento da Baixada Santista

CONESAN - Conselho Estadual de Saneamento

CRESAN - Comissões Regionais de Saneamento Ambiental

DAE - Departamento de Água e Esgoto

DOM - Diário Oficial do Município

EMBASA - Empresa Baiana de Saneamento

EMPLASA - Empresa Metropolitana de Planejamento da Grande São Paulo

ETA - Estação de Tratamento de Água

ETE - Estação de Tratamento de Esgoto

FAU - Faculdade de Arquitetura e Urbanismo

FESAN - Fundo Estadual de Saneamento

FGTS - Fundo de Garantia por Tempo de Serviço

FGV - Fundação Getúlio Vargas

FSP - Faculdade de Saúde Pública

FUNASA - Fundação Nacional de Saúde 
FUNDAP - Fundação de Desenvolvimento Administrativo

IBAM - Instituto Brasileiro de Administração Municipal

IBAMA - Instituto Brasileiro de Meio Ambiente e dos Recursos Naturais Renováveis

IBGE - Instituto Brasileiro de Geografia e Estatística

ISA - Indicador de Salubridade Ambiental

MPO - Ministério do Planejamento e Orçamento

OMS - Organização Mundial da Saúde

OPAS - Organização Panamericana de Saúde

PERH - Plano Estadual de Recursos Hídricos

PIB- Produto Interno Bruto

PLANASA - Plano Nacional de Saneamento

PLC - Projeto de Lei da Câmara do Deputados

PLS - Projeto de Lei do Senado

PMC - Prefeitura Municipal de Campinas

PMMA - Plano Municipal de Abastecimento de Água

PMSA - Prefeitura Municipal de Santo André

PMSJC - Prefeitura Municipal de São José dos Campos

PMSS - Projeto de Modernização do Setor de Saneamento

PNQS - Prêmio Nacional de Qualidade em Saneamento

PNSB - Pesquisa Nacional de Saneamento Básico

PNUD - Programa das Nações Unidas para o Desenvolvimento no Brasil

PUCCAMP - Pontifícia Universidade Católica de Campinas

RAE - Repartição de Águas e Esgotos

SABESP - Companhia de Saneamento Básico do Estado de São Paulo

SANASA - Sociedade de Abastecimento de Água e Saneamento S/A

SANEPAR Companhia de Saneamento do Paraná

SANESP - Companhia Metropolitana de Esgoto

SANESUL - Empresa de Saneamento do Mato Grosso do Sul

SEADE - Fundação Sistema Estadual de Análise de Dados

SEMASA - Serviço Municipal de Saneamento Ambiental

SESAN - Sistema Estadual de Saneamento 
SFH - Sistema Financeiro da Habitação

SFS - Sistema Financeiro do Saneamento

SNIS - Sistema Nacional de Informações em Saneamento

SUS - Sistema Único da Saúde

UN - Unidade de Negócios

UNICAMP - Universidade Estadual de Campinas

UNIP - Universidade Paulista

USP - Universidade de São Paulo

WHO - World Health Organization 


\section{Sumário}

$\begin{array}{ll}\text { 1.Introdução } & 01\end{array}$

2. Objetivos 30

2.1. Geral 30

2.2. Específicos 30

3. Método 31

3.1.Critérios e procedimentos para seleção dos municípios 34

3.2. Pesquisa bibliográfica 38

3.3. Pesquisa documental 42

3.4. Aplicação dos questionários 46

3.5. Indicadores para avaliação dos serviços de água e esgoto no âmbito nacional e no âmbito do Estado (São Paulo)

3.6. Investigação explicativa

3.7. Forma de análise dos resultados da pesquisa 52

4. Resultados da Pesquisa 54

4.1. Políticas públicas 56

4.2.Políticas de governo $\quad 82$

4.2.1. Campinas - gestão dos serviços de água e esgoto no âmbito do Município $\quad 82$

4.2.2. Santo André - gestão dos serviços de água e esgoto no âmbito $\begin{array}{ll}\text { do Município } & 97\end{array}$

4.2.3. São José dos Campos e Santos - gestão dos serviços de água e esgoto no âmbito do Estado 
4.2.3.1. Órgão gestor dos serviços de água e esgoto do Estado de

São Paulo - SABESP

4.2.3.2. São José dos Campos - gestão dos serviços de água e esgoto

no âmbito do Estado

4.2.3.3. Santos - gestão dos serviços de água e esgoto no âmbito do Estado

5. Discussão dos Resultados

6. Conclusão

7. Referências

7.1 Citadas

7.2 Consultadas 


\section{Introdução}

Esta tese analisa a gestão dos serviços de água e esgoto em alguns municípios de grande porte do Estado de São Paulo, Brasil, no período de 1996 a 2000. Para tanto, parte da hipótese de que há diferenças na eficiência e na eficácia da gestão desses serviços, no que se refere às esferas de governo estadual ou municipal e também quanto à existência de políticas públicas e políticas de governo.

Procurando demonstrar esta tese, inicia-se este trabalho focalizando a estruturação dos serviços de água e esgoto no Brasil, os quais começaram a ser estruturados na segunda metade do século XIX, juntamente com outras infra-estruturas, como energia e transportes, concedidos inicialmente a empresas estrangeiras. O governo retomou suas responsabilidades sobre esses serviços na década de 1930, passando então a gerir os recursos hídricos nacionais. Foram criados as empresas públicas e os sistemas de saneamento urbano, destacando-se, em 1971, a política pública nacional de saneamento básico, com a implantação do PLANASA.

Daí a importância de a gestão fundamentar-se, não só em políticas de governo, mas também em políticas públicas. Como política de governo entende-se aquela elaborada por e para determinada gestão governamental. E como política pública entende-se aquela definida por lei, promulgada pelo poder legislativo e sancionada pelo executivo. Por sua vez, a gestão, enquanto ato de gerir e administrar, precisa integrar, tanto as políticas aqui mencionadas, como a eficiência e a eficácia programadas.

Assim, esta hipótese, sob um aspecto, depende da eficiência da administração no que concerne à aplicação de recursos em planos, projetos e atividades que permitam levar água de boa qualidade e em quantidade suficiente à população, bem como coletar e tratar os efluentes, minimizando a poluição dos recursos hídricos e aumentando a qualidade de vida urbana. Esta hipótese depende também da eficácia dos resultados sociais, ou seja, se a população usufrui da água e dos serviços de esgoto, com nítida conseqüência 
em termos de abrangência dos serviços, incluindo um número cada vez maior de habitantes, tanto em relação à cobertura de água, como de esgoto.

Frente a estas considerações, o objetivo desta tese é demonstrar que, ao contar com políticas públicas e políticas de governo referentes aos serviços de água e esgoto, têm-se diferenças na eficiência e na eficácia da gestão municipal e estadual. No caso de esses serviços estarem sob o comando estadual, questões político-partidárias entre governador e prefeitos podem ter interferência direta na cobertura dos serviços para a população, nos índices de esgoto tratado e investimentos nos sistemas. Quando esses serviços estão sob comando do município, em geral há maior cobertura dos serviços para a população.

Para demostrar esta tese, desenvolve-se neste item o referencial teórico, fazendo uma revisão da literatura pertinente e estruturando o quadro do estado-da-arte em relação aos serviços de água e esgoto no Brasil, em especial no Estado de São Paulo, além de casos internacionais com relação a política pública, política de governo e sistemas de gestão. Foram tomados para análise e discussão indicadores como população atendida com água e esgoto, índice de tratamento de esgoto e investimento nos sistemas. Deste modo, a literatura revista é tomada como referencial teórico ALVES-MAZZOTTI E GEWANDSZNAJDE (1999), para se efetuar comparações e desenvolver interpretações, debater as principais questões e demonstrar a tese acima enunciada.

A necessidade de compreender a cadeia de relações que se estabelece por trás das aparências, fatos ou fenômenos, como menciona KÖCHE (1999, p. 29), é que move o interesse em desenvolver esta tese. Outros fatores corroboraram também este interesse, como a atuação da pesquisadora na área ambiental na Prefeitura de São Paulo, vivenciando problemas decorrentes da inexistência, até então, da inserção da gestão dos serviços de água e esgoto nas políticas públicas do município.

No Brasil, há muito tempo se percebe, em relação ao saneamento básico, e principalmente ao esgotamento sanitário, que se tem priorizado o 
abastecimento de água. Por que será que essa prioridade vem sendo adotada? Como se deu a formação dos sistemas de serviços de água e de esgoto?

Será devido à necessidade de contar com água potável distribuída a cada população? Ou será, como dizem TEIXEIRA e HELLER (2001), que o Brasil vem seguindo uma política de saneamento, desde a década de 1970, que não leva em consideração o perfil epidemiológico para a definição de prioridades, perfil este que poderia auxiliar na tomada de decisões, apontando onde investir, quanto investir e quando investir?

Há que se destacar o baixo índice de tratamento de esgoto existente na maioria dos municípios brasileiros, bem como o baixo índice de atendimento à coleta de esgoto para a totalidade da população dos municípios.

Segundo o BANCO MUNDIAL (1998), os cinco maiores problemas de poluição no Brasil são: saneamento básico inadequado, poluição do ar nas áreas metropolitanas, poluição das águas nas áreas urbanas, gestão precária de resíduos sólidos e poluição localizada, como em usinas industriais, mineração e queimadas. Observa-se que a deficiência de saneamento básico está entre esses cinco maiores problemas de poluição; que, por sua vez, concentra-se principalmente nas regiões Norte, Nordeste e Centro-Oeste e vêm causando anualmente milhares de casos de mortalidade infantil.

Embora as regiões Sul e Sudeste do Brasil apresentem melhores condições em relação ao abastecimento de água e ao esgotamento sanitário, o índice de tratamento dos esgotos é muito baixo em vários municípios, incluindo-se os de médio e grande porte.

Apresenta-se na tabela 1 a distribuição em termos percentuais das condições de coleta e tratamento de esgoto nas várias regiões brasileiras. 0 que pode ser observado é que $47,8 \%$ dos municípios não têm coleta de esgoto, sendo seus principais receptores os rios e o mar; dos restantes $52,2 \%$ que coletam os esgotos, apenas 20,2 \% têm tratamento (PNSB 2000). 
Tabela 1.Coleta e Tratamento de Esgoto nos Municípios Brasileiros.

\begin{tabular}{|l|c|c|c|}
\hline \multirow{2}{*}{ Região } & \multicolumn{3}{|c|}{ Percentual de Municípios (\%) } \\
\cline { 2 - 4 } & $\begin{array}{c}\text { Com coleta e } \\
\text { tratamento de Esgoto }\end{array}$ & $\begin{array}{c}\text { Com Coleta e sem } \\
\text { tratamento de Esgoto }\end{array}$ & Sem coleta de Esgoto \\
\hline Norte & 3,6 & 3,5 & 92,9 \\
\hline Nordeste & 13,3 & 29,6 & 57,1 \\
\hline Sudeste & 33,1 & 59,8 & 7,1 \\
\hline Sul & 21,7 & 17,2 & 61,1 \\
\hline Centro-Oeste & 12,3 & 5,6 & 82,1 \\
\hline Brasil (total) & $\mathbf{2 0 , 2}$ & $\mathbf{3 2 , 0}$ & $\mathbf{4 7 , 8}$ \\
\hline
\end{tabular}

Fonte: PNSB 2000.

Comparando-se com outros países do mesmo nível de renda, o Brasil está num patamar razoável de atendimento de água e esgoto. No entanto, em relação ao atendimento à população de baixa renda, o índice ainda é inadequado, e alcançar uma cobertura mais ampla nesse atendimento é o grande desafio. Quanto ao tratamento, este situa-se em nível limitado (BANCO MUNDIAL 1998).

Observando o panorama nos países de mesmo nível de renda, vê-se que os serviços de esgoto, na Bolívia e Venezuela, por exemplo, encontram-se em situação mais crítica: $66 \%$ e $74 \%$, respectivamente, como se vê na tabela 2.

Tabela 2. População Atendida com Serviços de Esgoto.

\begin{tabular}{|l|c|c|}
\hline \multicolumn{1}{|c|}{ País } & $\begin{array}{c}\text { População } \\
\text { (Habitantes) }\end{array}$ & $\begin{array}{c}\text { Esgotamento } \\
\text { sanitário (\%) }\end{array}$ \\
\hline Brasil & $\mathbf{1 7 0 . 1 1 5}$ & $\mathbf{7 7}$ \\
\hline México & 98.881 & 73 \\
\hline Argentina & 37.032 & 85 \\
\hline Colômbia & 42.322 & 85 \\
\hline Venezuela & 24.170 & 74 \\
\hline Bolívia & 8.329 & 66 \\
\hline Paraguai & 5.497 & 95 \\
\hline Uruguai & 3.337 & 95 \\
\hline China & 1.277 .558 & 38 \\
\hline Índia & 1.013 .662 & 31 \\
\hline Nigéria & 111.506 & 63 \\
\hline Etiópia & 62.565 & 15 \\
\hline
\end{tabular}

Fonte: WHO 2000.

Em relação à estruturação dos serviços de água e esgoto e intervenções de saneamento ocorridas no Brasil, vários pesquisadores, como JORGE (1987) e CAVALCANTI (1987) e SINGER (1974) apud JORGE (1987), discutiram 
amplamente o assunto, cabendo aqui apenas relembrar os principais fatos que nortearam a discussão destes trabalhos.

Três grandes períodos podem ser destacados na história do saneamento brasileiro. O primeiro, a partir da segunda metade do século XIX, quando estava em andamento o processo de industrialização e seus reflexos no país, e em que a implantação dos sistemas de saneamento ocorreu, juntamente com outros sistemas de infra-estrutura, como estradas de ferro, geração de energia, iluminação pública e transportes urbanos de um modo geral, dentre outros. Nessa época, houve favorecimento do Estado, com o incentivo à formação de empresas privadas, visando garantir o modus capitalista e adotando, para tanto, a política de concessão de serviços públicos a empresas privadas estrangeiras. Esse período extingui-se em 1927, em decorrência da crise mundial da economia capitalista (JORGE 1987; MPO 1995, v. 7).

O segundo período teve início na década de 1930, marcada pela transformação do Estado brasileiro, que abandonou a oligarquia das terras e iniciou, em 1937, um período de centralização do governo, que levou a uma ditadura. Nesse tempo as obras públicas foram implementadas basicamente com recursos públicos a fundo perdido. O Estado assumiu a execução e a gestão dos sistemas de serviços urbanos por meio desses investimentos públicos. As primeiras intervenções do governo federal em saneamento foram iniciadas com a edição do Código das Águas, em 1934, o qual lhe dava o poder de fixar as tarifas. O Código das Águas, apesar de sua ótica voltada para uma política de produção de hidroeletricidade, foi de fundamental importância para a gestão pública do setor de saneamento, pois estabeleceu os primeiros instrumentos de controle do uso dos recursos hídricos. Ao longo desse período, as empresas concessionárias estrangeiras foram nacionalizadas e estatizadas e os serviços de água e esgoto foram assumidos pelas prefeituras dos municípios. Para a implantação desses serviços em regiões menos desenvolvidas do país, o governo criou a Fundação de Serviços de Saúde 
Pública. Essa política em relação ao saneamento se estendeu até meados da década de 1960 (JORGE 1987; MPO 1995, v. 7).

Já o terceiro período, pós-1964, é marcado pela criação do Banco Nacional de Habitação - BNH, responsável pelo Sistema Financeiro da Habitação, que passou, em 1968, a se responsabilizar também pelo o Sistema Financeiro do Saneamento - SFS, instituindo então, em 1971, o Plano Nacional de Saneamento - PLANASA. O Plano foi um instrumento que o governo federal criou para que os Estados brasileiros implementassem, em suas cidades, sistemas de abastecimento de água e de esgoto. Foram criadas, assim, as empresas públicas, como a Companhia de Saneamento Básico do Estado de São Paulo - SABESP, e a Companhia de Saneamento do Paraná SANEPAR, dentre outras, às quais foram concedidos os sistemas de saneamento urbano. Com esta nova forma de gestão, os investimentos por parte do governo puderam ter condições de retorno, pois foram feitos a título de empréstimo.

O PLANASA exigia dos Estados a criação de companhias estaduais de saneamento, condição básica para a viabilização do Plano, sem o que os municípios não receberiam recursos financeiros do governo federal. Muitos municípios aderiram, outros não, pois decidiram manter a forma de gestão municipal dos serviços de saneamento básico, apesar das fortes pressões políticas para aderirem ao plano (FUNASA 1996).

Em conseqüência do PLANASA, àquela época, 27 companhias estaduais foram criadas no país e os municípios concederam a gestão do saneamento aos Estados, por meio de contratos de concessão, com prazos de 20 a 25 anos. O Estudo de Viabilidade Global do Plano estabelecia uma programação, segundo a qual os municípios deveriam integrar-se ao plano por meio de companhias estaduais de saneamento, mesmo aqueles em que os serviços de água e de esgotos estivessem sob a assistência de órgão federal, como a FUNASA, em municípios das regiões Norte e Nordeste do Brasil, ou municipais, como Campinas - SP, Santo André - SP, dentre outros. Esta 
exigência tinha por objetivo a consolidação, o fortalecimento e a viabilização das metas do PLANASA no Estado (BNH 1975).

Anteriormente à criação do PLANASA, apesar de já existirem municípios em que a responsabilidade pela operação dos serviços ficava a cargo do Estado, estes eram em sua maioria executados pela administração municipal. Os municípios que já tinham seus sistemas de água e de esgoto eficientes não eram favoráveis à adesão ao PLANASA. Assim, Campinas - SP e Santo André - SP, pela influência que exerciam nos demais devido a seu porte e presença econômica, eram bastante visados pelo governo federal, que os queria participando do Plano Nacional. Por outro lado, municípios como esses, de médio e grande portes, eram os mais visados por parte do governo federal (FUNASA 1996).

Segundo Relatório do BNH 1975, o objetivo básico do PLANASA era a eliminação do déficit do setor de saneamento básico, através de programação adequada que permitisse atingir o equilíbrio entre a demanda e a oferta de serviços, no menor tempo possível, com mínimo custo. Além disso, objetivava a manutenção, em caráter permanente, do equilíbrio atingido entre a demanda e a oferta de serviços de saneamento básico. O plano previa também um atendimento extensivo a todas as cidades brasileiras, mesmo àquelas constituídas por núcleos urbanos mais pobres. Já no que tange à instituição de política tarifária, esta deveria estar de acordo com as possibilidades de pagamento dos consumidores, com a demanda de recursos e com os serviços oferecidos, de forma a estabelecer um equilíbrio permanente entre receita e despesa. Havia ainda uma política de redução de custos operacionais, em função da economia de escala, prevendo reflexos diretos no esquema tarifário. Finalmente, o plano previa o desenvolvimento de programas de pesquisas, treinamento e assistência técnica.

Por sua vez, o Sistema Financeiro do Saneamento, através do Banco Nacional da Habitação, era o responsável pelo suporte financeiro, administrativo, técnico e operacional, para que as metas do Plano fossem atingidas. Neste âmbito, observa-se que, até o início dos anos de 1980, os 
investimentos do PLANASA (mais de US\$ 6 bilhões) foram aplicados em obras de saneamento. Estes recursos eram provenientes principalmente do Fundo de Garantia por Tempo de Serviço - FGTS (BNH 1975).

“O FGTS foi criado pela Lei No 5.107, de 13 de setembro de 1966, com o objetivo de proteger o trabalhador regido pela Consolidação das Leis do Trabalho-CLT, contra despedidas sem justa causa, mediante a formação de um pecúlio a ser recebido quando da demissão. O Fundo possibilita, ainda, a arrecadação de recursos para aplicação em programas sociais, tais como: habitação popular, saneamento básico e infra-estrutura urbana (ex. construção de casas populares, calçamento de ruas, rede de esgotos sanitários etc.)" (grifo meu). Formado por depósitos mensais, efetuados pelas empresas em nome de seus empregados, no valor equivalente a $8 \%$ (oito por cento) das remunerações que Ihes são pagas ou devidas; em se tratando de contrato temporário de trabalho com prazo determinado, o percentual é de $2 \%$ (dois por cento), conforme dispõe o inciso II, do art. $2^{\circ}$, da Lei $n^{\circ}$ 9.601, de 21.01.98. Atualmente, a Lei que dispõe sobre o FGTS é a de $n^{\circ}$ 8.036, de 11.05.90." (MTE 2002).

Mas será que o PLANASA teve sucesso? Segundo Relatório da Conferência Nacional de Saneamento - CNS (1999), apesar de contradições contidas no PLANASA, este pode ser considerado um dos planos mais bem sucedidos da administração pública brasileira, pois, "em pouco mais de 20 anos foi possível estender os serviços de abastecimento de água e esgotos sanitários para cerca de 70 milhões de pessoas" (CNS 1999, p.17), como pode ser observado na tabela 3.

Tabela 3. Evolução da Cobertura de Água e Esgoto no Brasil, 1970-1991.

\begin{tabular}{|l|c|c|}
\hline \multicolumn{1}{|c|}{ Ano } & $\mathbf{1 9 7 0}$ & $\mathbf{1 9 9 1}$ \\
\hline População Total & 93.139 .100 & 146.917 .600 \\
\hline População Urbana & 52.085 .000 & 110.876 .100 \\
İ́dice de Cobertura de Água & $45,7 \%$ & $81,2 \%$ \\
Índice de Cobertura de Esgoto & $44,2 \%$ & $64,3 \%$ \\
\hline População Rural & 41.054 .100 & 36.041 .700 \\
Índice de Cobertura de Água & $3,2 \%$ & $6,8 \%$ \\
Índice de Cobertura de Esgoto & $2,0 \%$ & $9,0 \%$ \\
\hline
\end{tabular}

Percebe-se nesse período, 1970-1991, a intensa urbanização brasileira. Por outro lado, houve um aumento significativo em termos de cobertura de 
água e, de forma mais tímida, da cobertura de esgoto, pois, quanto à evolução do nível de cobertura de abastecimento de água na área urbana, passou-se de $45,7 \%$ (1970) para 81,2\% (1991). Já na área rural passou de 3,2\% (1970) para 6,8\% (1991). Em relação ao esgotamento sanitário, a evolução aconteceu de forma muito mais lenta pois, em 1970, o nível de atendimento na área urbana era de $44,2 \%$ e passou para $64,3 \%$. Quanto à área rural, o atendimento era de $2,0 \%$, em 1970, e passou para 9,0\%, em 1991. No entanto, observam-se disparidades gritantes quando se compara o índice geral brasileiro de cobertura dos serviços de água e esgoto com os índices regionais: como exemplo tem-se que, daqueles $64,3 \%$ do nível de atendimento de esgoto que o Brasil apresentava em 1991, o destaque era para as regiões Sudeste $(80,9 \%)$ e Sul $(64,7 \%)$, sendo que, por sua vez, a região Norte apresentava $36,4 \%$, a Nordeste $35,8 \%$ e a Centro-Oeste 41,8\% (CNS 1999; MPO 1995, v.7).

A falta de adesão ao PLANASA por parte dos municípios de médio e grande porte, como também outros fatores, como o desemprego e consequentemente a queda salarial, levaram à extinção, em 1986, do BNH, executor do PLANASA, e a responsabilidade quanto ao financiamento do saneamento ficou a cargo da Caixa Econômica Federal.

Durante o processo de implantação do PLANASA, as prefeituras dos municípios que não aderiram ao plano criaram a Associação Nacional dos Serviços Municipais de Água e de Esgoto - ASSEMAE e, em meados da década de 80, por reivindicação dessa Associação, os órgãos municipais autônomos passaram a participar do PLANASA. Embora alguns autores, ao analisarem esse período de desenvolvimento nacional, tenham observado que as receitas tarifárias dos serviços municipais de saneamento, de forma geral, não cobriam custos de investimento, manutenção e operação dos sistemas, o déficit gerado era coberto por dotações orçamentárias. A ausência de uma política de saneamento, a partir da deterioração do PLANASA, resultou em ações públicas desordenadas e desarticuladas, por isto mesmo, incapazes de promover o adequado equacionamento dos problemas relacionados ao 
abastecimento de água e ao esgotamento sanitário no Brasil (FUNASA 1996; JORGE 1987; MPO 1995, v.7).

Depois da extinção do PLANASA, ocorreram reformas administrativas e os recursos financeiros foram repassados para as prefeituras e companhias estaduais, através de programas instituídos pelo governo federal. A fragilidade das políticas públicas e a precariedade dos serviços de saneamento no país, somadas ao significativo crescimento populacional, principalmente nas grandes cidades, levou o governo brasileiro a conceber, em 1992, o Projeto de Modernização do Setor de Saneamento - PMSS.

"O PMSS é composto de duas linhas de ação complementares e interdependentes. A primeira é o componente institucional e visa, principalmente, desenvolver estudos aplicados para a reestruturação do setor. A segunda contempla um componente de investimentos e modernização em três Companhias Estaduais de Saneamento Básico (CESB's) - a Companhia Catarinense de Águas e Saneamento (CASAN), a Empresa Baiana de Saneamento (EMBASA) e a Empresa de Saneamento do Mato Grosso do Sul (SANESUL), no prazo máximo de cinco anos, de condições técnicofinanceiras que assegurem uma política saudável de financiamento dos investimentos. Os resultados deste componente deverão, também, complementar o componente institucional do PMSS e proporcionar um efeito demonstração para as demais CESB's." (MPO 1995, v.1, p.27-28).

O PMSS foi dividido em 2 fases, o PMSS-I e o PMSS-II. O PMSS-I iniciou no ano de 1993 e foi finalizado no ano de 2000. Já o PMSS-Il está em andamento, tendo iniciado neste ano de 2002. Ainda em relação ao PMSS-I, foi executado o componente institucional, previsto na primeira linha de ação do Projeto, com a elaboração de proposta de legislação federal sobre a prestação dos serviços de saneamento e apoio aos Estados do Espírito Santo, Mato Grosso, Rio de Janeiro e São Paulo, entre outros, sobre proposição de instrumentos de regulação e controle. Já em relação à segunda linha de ação do Projeto - componente investimentos - foi executado pelas companhias EMBASA, SANESUL e CASAN. O PMSS-I contou com recursos do Banco Mundial da ordem de US\$250 milhões e a mesma quantia de contrapartida nacional (SNIS 2002). 
Quanto ao PMSS-II, os recursos são da ordem de US\$150 milhões do Banco Mundial, US\$ 93,5 milhões do Japan Bank for International Cooperation - JBIC e US\$ 56,5 milhões de contrapartida dos prestadores de serviços. Esta fase do PMSS visa dar continuidade ao reordenamento institucional do saneamento, bem como ampliar a cobertura dos serviços de água e esgotamento sanitário em Estados das regiões Norte, Nordeste e CentroOeste, dentre outros (SNIS 2002).

Por outro lado, projetos de lei foram elaborados na tentativa de estabelecer políticas públicas nacionais para o saneamento, tais como, o Projeto de Lei da Câmara do Deputados $n^{\circ} 199$, de 1991 (PLC 199), e o Projeto de Lei do Senado $n^{\circ} 266$, de 1996 (PLS 266). O primeiro, de autoria de Irma Passoni, foi elaborado por entidades e sindicatos de trabalhadores do setor de saneamento. Dispunha sobre a Política Nacional de Saneamento, estabelecendo, em seu artigo $4^{\circ}$, que cabia aos municípios a organização e prestação, diretamente ou mediante regime de concessão ou permissão, dos serviços públicos de saneamento e, em seu parágrafo único, estabelecia que os serviços de saneamento deveriam integrar-se com as demais funções essenciais de competência municipal, de modo a assegurar prioridade para a segurança sanitária e o bem-estar ambiental de seus habitantes. O PLS 266, de 1996, de autoria do então senador José Serra, estabelecia diretrizes para o exercício do poder concedente e para o inter-relacionamento entre União, Estados e Municípios. Trazia também, segundo alguns autores que participaram da Conferência Nacional de Saneamento de 1999, colocações relativas a uma ação privatizante do governo federal, que definia como estaduais os poderes concedentes dos serviços de água e de esgotos das regiões metropolitanas, aglomerações urbanas e microrregiões. O objetivo principal dessa iniciativa, conclui-se, seria facilitar o processo de privatização das empresas estaduais de saneamento (SÃO PAULO 1990; CNS 1999).

O PLC 199, de 1991, que tinha sido aprovado pelo Congresso em 1994, foi vetado na íntegra pelo executivo federal. Dado o avanço que este projeto proporcionaria para o estabelecimento das políticas nacionais de saneamento 
no país, destaca-se aqui os motivos que levaram o Presidente da República a vetá-lo, expressos na mensagem n 4/95:

Senhor Presidente do Senado Federal, Comunico a Vossa Excelência que, nos termos do parágrafo $1^{\circ}$ do artigo da Constituição Federal, decidi vetar integralmente o Projeto de Lei $n^{\circ} 199$, de 1993 (n $n^{\circ}$ 53/91 na Câmara dos Deputados), que "Dispõe sobre a Política Nacional de Saneamento, seus instrumentos e dá outras providencias".

O Ministério da Fazenda assim se manifestou:

"Em que pese o louvável propósito da ilustre parlamentar, há que registrar, sob o enfoque econômico, as seguintes observações:

a) saneamento é atribuição do governo local, cabendo à União instituir as diretrizes para o saneamento básico;

b) a criação do Sistema Nacional de Saneamento, do Conselho Nacional de Saneamento e sua Secretaria Executiva, a instituição de planos qüinqüenais e a exigência de elaboração de relatórios anuais sobre a situação de salubridade ambiental no Brasil contribuirão não só para burocratizar, como para onerar a ação governamental no setor; (grifo meu)

c) a constituição do Fundo Nacional de Saneamento - Fusan, por sua vez, apresenta inconvenientes tais como: i) possibilidade de transferir indiretamente à União gastos próprios de Estados e Municípios; ii) dificuldades operacionais na administração do Fundo, vez que o projeto de lei prevê recursos orçamentários de diferentes esferas (grifo meu) (federal, estadual e municipal); iii) conflitos de objetivos com o FGTS e a Seguridade Social, que têm políticas e administrações próprias.

d) A proposição, portanto, é contrária ao interesse público.

Estas, Senhor Presidente, as razões que me levaram a vetar totalmente o projeto em causa (....)" (BRASIL 1995, p..274).

Percebe-se nessa mensagem que o veto foi de cunho altamente políticopartidário e que mais uma vez os reflexos de tal comportamento comprometem com o avanço do saneamento e da qualidade de vida do cidadão.

Em relação à tramitação do PLS 266, de 1996, este encontra-se desde 10/04/2002 na Comissão de Serviços de Infra-estrutura, conforme diz no portal legislativo do Senado Federal (SENADO 2002).

Desde então, o Brasil não conta com políticas públicas nacionais para o saneamento básico, o que leva Estados e municípios a definições próprias de suas políticas públicas, podendo provavelmente estar desarticuladas, tanto em âmbito de governo como entre setores de planejamento. 
A questão é sumamente importante, tanto que, em 2001, foi elaborado o Projeto de Lei 4147, que trata das diretrizes nacionais para a prestação dos serviços de saneamento básico e define a política de saneamento. Atualmente encontra-se em tramitação no congresso nacional. A discussão está centrada, principalmente, na definição sobre a titularidade desses serviços quando ultrapassam os limites de um município e quando estes encontram-se em regiões metropolitanas.

No que tange à forma de gestão dos serviços de abastecimento de água e esgotamento sanitário no Brasil, estes vêm sendo administrados pelos Estados por meio de companhias, mediante concessões municipais, e pelos municípios, por meio de administração municipal direta, ou autarquias, ou empresas públicas ou ainda assistidos pela Fundação Nacional de Saúde. Das 27 companhias estaduais existentes, a do Estado do Acre transformou-se em autarquia e passou a administrar os serviços da antiga companhia, com exceção dos serviços da capital do estado, que se tornou um serviço local.

Conforme mostra a tabela 4, dos 4.491 municípios brasileiros existentes em 1995, 652 tinham os serviços administrados pelos municípios, 267 eram administrados pela Fundação Nacional de Saúde, 3.191 pelas companhias estaduais e sobre 381 não havia informações. Em termos de população total, os municípios operados pela Fundação Nacional de Saúde contemplavam $5,3 \%$ do total da população brasileira, os operados diretamente pelas municipalidades somavam $15,3 \%$ e as companhias estaduais administravam serviços em municípios que abrigavam, no conjunto, $76,3 \%$ dos brasileiros. Para os restantes $3,1 \%$ da população, foram registrado pela FUNASA como municípios cuja gestão dos serviços de saneamento básico não é identificada (FUNASA 1996). 
Tabela 4. Número de Municípios, Segundo a Esfera Administrativa do Órgão Gestor do Serviço de Abastecimento de Água, por Região.

\begin{tabular}{|c|c|c|c|c|}
\hline Região & Municipal & $\begin{array}{c}\text { Fundação } \\
\text { Nacional de } \\
\text { Saúde }\end{array}$ & Estadual & $\begin{array}{c}\text { I.N.D. } \\
\text { (informação } \\
\text { não } \\
\text { identificada) }\end{array}$ \\
\hline Centro-Oeste & 0 & 14 & 328 & 37 \\
\hline Norte & 13 & 37 & 202 & 46 \\
\hline Nordeste & 25 & 117 & 1149 & 218 \\
\hline Sudeste & 555 & 73 & 792 & 12 \\
\hline Sul & 59 & 26 & 720 & 68 \\
\hline Brasil & 652 & $\mathbf{2 6 7}$ & 3191 & 381 \\
\hline
\end{tabular}

Fonte: FUNASA 1996.

Dos 24 municípios brasileiros com mais de 500.000 habitantes, existentes até 1995, 6 eram operados por serviços municipais: Porto Alegre, Campinas, Santo André, São Bernardo do Campo, Guarulhos e Osasco. Entre os 18 grandes municípios operados por companhias estaduais, apenas 3 não eram capitais de estado: Nova Iguaçu, Duque de Caxias e São Gonçalo, todos no Rio de Janeiro (FUNASA 1996).

Em todas as regiões do Brasil, as companhias estaduais têm presença marcante. Entretanto, muitas delas ainda não conseguiram superar a crise econômica que se iniciou nos anos de 1980, principalmente devido às dificuldades em adequar os seus custos à arrecadação tarifária.

Em relação aos 5.507 municípios brasileiros (IBGE* 2000), tem-se a comentar que, conforme dados da ASSEMAE (2000a, 2000b), 1.700 administram de forma local seus serviços de água e esgoto, sendo que a sua maioria pertence aos Estados de São Paulo e Minas Gerais e os 3.807 municípios restantes são administrados pelas companhias estaduais.

$\mathrm{Na}$ maioria dos municípios, os contratos de concessão ainda estão em vigor. No entanto, uma parcela significativa dos municípios está sem contrato ou com a concessão vencida. Destaque-se que alguns desses serviços sem

\footnotetext{
* O Brasil passa a contar a partir de 2001 com 5.561 municípios (IBGE 2002). Nesta tese foi tomado como referencial - 5.507 municípios - existentes até 2000 (IBGE 2000).
} 
concessão formalizada correspondem a capital de estado e municípios de grande porte, como São Paulo e Santos (SNIS 1999).

Há que se mencionar que "os contratos de concessão dos serviços de saneamento, por não terem nascido de negociações $e$ interesses administrativos recíprocos, mas por terem sido impostos chantagiosa e autoritariamente pela burocracia ditatorial do governo federal e seus pressupostos, então nomeados para os estados, não obedecem claramente às formas e regras jurídicas e não contêm e nem definem inteiramente as obrigações das concessionárias e os direitos do poder concedente, especialmente no que se refere às obrigações da concessionária de prestar contas e informações (....). Estas têm-se negado sistemática e acintosamente a fornecer as informações técnicas e econômicas solicitadas pelos municípios e a discutir cláusulas contratuais, impedindo de forma autoritária e ilegal a fiscalização do contrato de concessão (....)" (Peixoto 1994, p. 10 - 11).

Pela literatura específica, observa-se que muitas companhias estaduais têm-se mostrado ineficientes quanto à prestação de serviços, levando diversas municipalidades a discussões sobre a possibilidade de retomarem a administração desses serviços. Alguns municípios do Estado de São Paulo têm retomado esses serviços de água e esgoto das concessionárias, dentre eles: Mauá, Diadema e Jundiaí. O Município de Mauá criou em 1996 uma autarquia para tratar do saneamento básico, portanto, esses serviços deixaram de ser prestados pela SABESP. Quanto ao Município de Diadema, este retomou em 1995 os serviços de fornecimento de água e de esgotamento sanitário, que atualmente estão sendo prestados por meio de Companhia Municipal de Economia Mista, tendo o município como acionista majoritário. Recentemente, 1999, o Município de Jundiaí também criou um departamento de água e esgotos na forma de empresa de sociedade anônima.

Observa-se, no entanto, que criar órgãos ambientais oficiais não é o suficiente. Imprescindível é a articulação e integração inter e intra-setoriais da dimensão ambiental entre órgãos governamentais e agentes privados, como mostra NEDER (1996). 
Mas ainda, verifica-se que "A situação financeira de muitas empresas estaduais de abastecimento de água é difícil. Elas têm recorrido a práticas de contabilidade inflacionárias para preservar seus balanços, de forma que o saldo entre as receitas operacionais recentes e as despesas mal permite o uso dos recursos limitados para servir sua dívida, sem contar o financiamento de novos investimentos. Os estados não estão em melhor situação de crédito. Em virtude disso, tanto os estados, quanto suas empresas dependem principalmente da disponibilidade de fundos de investimentos subsidiados do governo federal ou de instituições multilaterais de crédito a fim de financiar novos investimentos (....)" (BANCO MUNDIAL 1998, p.31).

Essa vulnerabilidade financeira, tanto em relação ao Estado quanto às empresas estaduais, tem contribuído cada vez mais para a discussão do tema concessões de serviços públicos à iniciativa privada, o que é bastante recente no Brasil. Some-se a isso ainda a abertura de financiamentos por parte da Caixa Econômica Federal a programas de saneamento básico com a participação da iniciativa privada, o que vem corroborando esse tipo de política adotada pelo governo federal de criar financiamento para essa forma de gestão desses serviços.

Cabe ainda comentar que, no Brasil, para o setor de saneamento básico, a legislação não permite a transferência definitiva dos ativos para a iniciativa privada, portanto o termo privatização não cabe para o saneamento, mas, sim, concessão dos serviços.

Em se tratando de parceria pública - privada de serviços de saneamento, é importante saber que no mundo há dois tipos de modelos: o francês, que prevê uma gestão delegada ou contratual, e o modelo inglês, que se volta para a privatização. No modelo francês, os ativos permanecem com o setor público, enquanto que, no modelo inglês, o operador privado compra os ativos.

Por isto é que, como mostra a publicação Análise Setorial, editada pela Gazeta Mercantil em 1998, quando os ativos permanecem com o setor público, 
os contratos existentes podem ser classificados como contrato de prestação de serviços, contrato de gerenciamento, contrato de arrendamento e contrato de concessão.

No contrato de prestação de serviços ou de operação, também conhecido por terceirização, o poder concedente contrata uma empresa privada para administrar, operar $\mathrm{e}(\mathrm{ou})$ manter os serviços, sendo que os investimentos e o estabelecimento de objetivos, metas e padrões de desempenho ficam por conta do poder concedente. No contrato de gerenciamento, o poder concedente delega a uma empresa privada a responsabilidade parcial ou total pela gestão dos serviços, ficando esta obrigada a prestar contas quanto aos resultados dos serviços, receitas, dentre outros. Por outro lado, o poder concedente fica responsável pelo estabelecimento dos objetivos, metas, padrão dos serviços, manutenção e ampliação do sistema. Quanto ao contrato de arrendamento, o poder concedente faz os investimentos por meio de um fundo, que é constituído por parcela da arrecadação tarifária, e o operador faz a manutenção e a operação do sistema. Já no contrato de concessão, o poder concedente passa à empresa privada a responsabilidade para a realização da gestão da manutenção e da operação dos serviços. Os investimentos e os riscos são de responsabilidade da concessionária. Os ativos são cedidos pelo poder concedente à concessionária por um prazo entre 20 e 30 anos. Neste caso, a concessão pode ser plena ou parcial. A concessão plena se refere aos serviços de água e esgoto, e a concessão parcial se refere ou à água ou ao esgoto. Quando a concessão é parcial e se refere ao esgoto, esta pode ser para o sistema completo ou apenas para o tratamento. Concessão plena é aquela onde a empresa privada tem responsabilidade total sobre a operação, manutenção, administração e investimentos de capital para a expansão dos serviços de água e esgoto. Já na concessão parcial, o operador constrói, uma nova instalação e se responsabiliza pela operação e administração (BNDES 1998).

Quando os ativos permanecem temporariamente ou definitivamente com o setor privado, os contratos podem ser dos seguintes tipos: Build, Operate, 
Own, Transfer (BOOT) ou Build Operate Transfer (BOT), ou empresas de economia mista ou ainda do tipo aquisição total dos ativos também conhecido como modelo inglês. Este último tipo não é utilizado no Brasil, pois a Constituição Federal não permite No tipo BOOT, proveniente das palavras, Build, Operate, Own e Transfer, o operador constrói, opera, administra como proprietário sistemas de água e esgotos, completos ou algumas instalações e, ao final do contrato, transfere a patrimônio e os ativos para o poder concedente. Geralmente este tipo de contrato tem duração entre 20 e 30 anos e é utilizado, de maneira geral, para a construção de novas estações de tratamento de água e esgotos. O setor público paga uma tarifa à concessionária, para cobrir os custos de operação e manutenção e assegurar o retorno do investimento ao final do prazo de concessão. A concessionária é responsável pelo risco total do investimento. Já no tipo BOT, também proveniente das palavras Build, Operate e Transfer, o operador constrói e opera uma parte do sistema e, ao final do contrato, transfere o patrimônio e os ativos ao poder concedente. A gestão dos recursos financeiros e os mecanismos de arrecadação e cobrança são de responsabilidade do poder concedente. No caso das empresas de economia mista, o poder concedente estabelece a concessão por meio de uma empresa pública de saneamento e compartilha com a iniciativa privada ações de uma sociedade anônima (LIMA 2000; GAZETA 1998).

PETRY (1997) enfatiza que as companhias privadas são chamadas geralmente para atividades operacionais, tais como, construção de instalações de tratamento de água e de esgoto, sob controle da administração. Assim sendo, a gestão fica por conta da administração pública. Um número limitado de países tem desenvolvido uma tradição contínua de companhias privadas para o gerenciamento de instalações públicas de distribuição, entre eles, França, Estados Unidos e Espanha.

Quanto à gestão do saneamento básico na Comunidade Européia, vêm sendo adotadas cinco categorias: gestão pública municipal, gestão pública municipal com estruturas intermunicipais ou regionais, gestão delegada pública 
e gestão delegada mista ou privada. Desse modo destaca-se que, na Alemanha, Grécia, Dinamarca, Holanda, Irlanda, Itália, Luxemburgo, Escócia, Irlanda do Norte e Portugal, o modelo da gestão do saneamento básico é predominantemente público e municipal. Já na Bélgica, pequena parcela da gestão é privada, porém a maioria é pública e municipal, enquanto que, na Espanha, é parcialmente privado e municipal. Já na França, a predominância é da iniciativa privada, enquanto que, na Inglaterra, é privatizado e regional. Nota-se que o modelo de gestão do saneamento básico na Europa é geralmente público e municipal, exceto na França e Inglaterra. O modelo inglês é objeto de controvérsia na própria Inglaterra e o modelo Francês é consensual e funciona (BAU 1996a; 1996b ).

Em relação à gestão do saneamento na França, pode-se dizer que existem dois tipos de gerenciamento do sistema de água: as Agências de Bacias e o Sistema delegado para o setor privado. As Agências de Bacias foram criadas em 1964. Têm estrutura pública com um corpo administrativo responsável por um Comitê de Bacia. Os membros do Comitê são eleitos pelas municipalidades locais, regionais, representantes dos usuários de água, indústria, pescadores, ecologistas, organização dos consumidores (LESOUËF 1996). Já o modelo do tipo gestão delegada nasceu no final do século XIX. Cerca de $30 \%$ dos municípios têm seus serviços de água operados pelo setor público e $70 \%$ pelo setor privado. Estes serviços também podem ser realizados isoladamente ou por consórcios com outras unidades locais de governo. Por muitos anos esses municípios vizinhos vêm tentando solucionar seus problemas de infra-estrutura por meio de parcerias, tais como, as associações intermunicipais, para o que têm delegado suas responsabilidades. As municipalidades podem operar seus próprios sistemas, ou delegar a operação e gerenciamento a empresas privadas, tanto para sistemas de água, quanto para sistemas de esgoto. A regulação do setor de saneamento na França é de competência do Ministério da Saúde, sendo as normas de gerenciamento de recursos hídricos e de saneamento ambiental de responsabilidade do Ministério do Meio Ambiente (PETRY 1997; GAZETA 1998). 
A França tem 4 níveis políticos de organização institucional: o Estado, a Região (22 regiões), o Departamento (96 departamentos) e a Municipalidade (36.000 municipalidades). O Estado estabelece normas gerais, tais como, as obrigações e direitos legais das Municipalidades, os padrões da água potável e as medidas de controle de poluição. As responsabilidades básicas no campo da água e esgoto, bem como a coleta de resíduos e iluminação pública são da Municipalidade. O Departamento pode trazer alguns recursos financeiros, especialmente para pequenas municipalidades rurais, enquanto que a Região tem uma função de planejamento. Já o Estado tem uma função importante, que é a de ser um órgão financiador (PETRY 1997).

Quanto à Inglaterra, as entidades gestoras dos serviços de água e esgoto foram privatizadas em 1989, com o governo Thacher, resultando num total de 10 empresas operadoras dos serviços. Salienta-se o fato de que, mesmo antes do período Thacher, já existiam empresas privadas operando o setor, o que mostra que a privatização já estava em andamento antes desse período. O sistema de regulação foi construído em 1989, quando da edição do Water Act, sendo o Office of Water Services o órgão responsável. A regulação das tarifas foi definida pelo Office of Water Services, pois na Inglaterra não existe medição de consumo (BAU 1996a, 1996b; GAZETA 1998).

Destaca-se, também, como de igual importância para o conhecimento, a gestão do saneamento básico nos Estados Unidos da América e na América Latina, em países como Colômbia e Argentina.

Nos Estados Unidos da América, os serviços de água e esgoto são operados basicamente pelo Estado, de forma descentralizada e sob a responsabilidade dos municípios. A partir dos anos de 1990, alguns municípios começaram a ter seus serviços operados pela iniciativa privada. A regulação desses serviços de saneamento básico dá-se por meio de comissões de serviços públicos e entidades estatais. As tarifas são estipuladas conforme características da região em relação à escassez ou abundância de água, entre outros (GAZETA 1998) 
Na América Latina cabe destacar o caso da Colômbia onde, segundo FERNANDÉZ-GIRALDO (1998), a intervenção do Estado subsidiando, tanto os investimentos, como a operação e manutenção, aumentou o acesso da população aos serviços. Os principais beneficiados foram as populações das camadas médias e altas, enquanto os usuários mais pobres continuaram mantendo um acesso formal muito baixo, ou quase nulo, à infra-estrutura. $A$ cobertura limitada dos custos, por meio das tarifas, e o acelerado crescimento das cidades latino americanas fez com que os recursos dos governos fossem direcionados mais para a operação do que para a manutenção dos sistemas, muito pouco para a reposição e, de maneira ocasional, para programas de ampliação. A falta de investimentos para uma manutenção adequada, frente à urgência na reposição dos sistemas de água e esgoto, fez com que o Estado delegasse a responsabilidade da operação e da manutenção dos serviços aos governos locais. Apesar da maior governabilidade esperada de uma administração direta por meio dos governos locais, os sistemas políticos em muitos países da América Latina não permitem, a longo prazo, maior compromisso entre o governo e grupos sociais com objetivos de estender os serviços a toda a população.

A legislação Colombiana define de forma precisa as responsabilidades de cada um dos níveis de governo, atribuindo ao nível local assegurar a prestação do serviço, direta ou indiretamente, e ao nível nacional a regulação, o controle e a fiscalização. As funções de regulação são exercidas por comissões, enquanto $\mathrm{o}$ controle $\mathrm{e}$ fiscalização são exercidos pela Superintendência de serviços públicos. A regulação é uma função do Estado, exercida por meio de comissões de regulação. As principais funções das Comissões são: regular os monopólios naturais para evitar abusos de poder, tanto em respeito ao mercado quanto aos usuários; promover a competitividade econômica na oferta dos serviços, a partir dos custos; definir o regime tarifário para a prestação dos serviços, a partir de custos economicamente eficientes e fixar as regras para outorgar subsídios; estabelecer o marco regulatório que permita avaliar a gestão das empresas; buscar incrementos progressivos da qualidade dos serviços e promover a formação e o desenvolvimento adequado 
das empresas reguladas. A separação de funções entre aquele que regula e aquele que controla e fiscaliza é bastante particular e, pouco utilizada internacionalmente, tendo como objetivos evitar abusos de posição dominante por parte do controlador. A Lei Colombiana define, ainda, os níveis máximos de subsídio e sobre taxa a ser cobrada nas tarifas dos serviços públicos e deixa por conta dos administradores locais a opção de aportar recursos, quando querem estabelecer tarifas mais baixas para os usuários de menor poder aquisitivo, permitindo assim o sistema de subsídios cruzados. Neste novo marco, a regulação é uma das principais ferramentas para criar condições de extensão dos serviços públicos. Desse modo, o objetivo principal da regulação é criar e preservar as condições que se obteriam em mercados competitivos, assegurando uma eficiente prestação dos serviços, em benefício dos usuários. A regulação nacional é necessária onde os governos locais podem afetar as políticas nacionais, que vão desde a estabilização macroeconômica, à diminuição da pobreza e à proteção de meio ambiente (FERNANDÉZGIRALDO 1998).

Na Argentina, o governo recebeu em 1990 auxílio e apoio do Banco Mundial para promover uma grande entrada do capital privado nos serviços de água e esgoto. Este processo resultou, em 1993, na transferência dos serviços da área da Região Metropolitana de Buenos Aires, para operadores estrangeiros privados $\mathrm{e}$ investidores locais. $\mathrm{O}$ modelo adotado foi o de concessão por 30 anos, sendo o concessionário responsável pela operação, manutenção e administração dos sistemas, investindo e expandindo os serviços (GAZETA 1998).

Analisando as diferentes formas de gestão dos serviços, conforme relatos do Banco Mundial observa-se que, por um lado, que a entrada da iniciativa privada tem o potencial de aumentar significativamente a cobertura de serviço para as populações de baixa renda das zonas urbanas, por meio de maiores investimentos, o que torna esses serviços mais fáceis de pagar. Por outro lado, é preciso ter cuidado para evitar uma situação em que as áreas mais lucrativas sejam melhor servidas por concessões privadas, enquanto que 
as áreas mais pobres são deixadas com as empresas estaduais, financeiramente ainda mais fracas, e que por isso não têm condições de investir e expandir o sistema (BANCO MUNDIAL 1998, p.33). Procurando soluções para esses problemas o Banco Mundial preconiza algumas medidas, como:

\begin{abstract}
"As tarifas para os clientes atuais devem cobrir o custo total dos serviços proporcionados. Isto assegurará que os lucros dos investimentos existentes contribuam para a geração interna de recursos que podem ser investidos, a fim de ampliar a cobertura para áreas que atualmente não contam com serviços. Os contratos de concessão precisam ser claros quanto às metas da ampliação da cobertura dos serviços, inclusive cobertura das populações mais pobres. A inclusão de alternativas de baixo custo e de participação pública na elaboração dos planos e opções de investimento pode reduzir o custo e dessa forma permitir que os pobres possam pagar por esses serviços" (BANCO MUNDIAL 1998, p.33).
\end{abstract}

Na opinião de IDELOVITCH (1995), em países em desenvolvimento, uma séries de problemas têm levado à baixa produtividade e ao baixo desempenho dos serviços de água em companhias públicas. Destaca dentre estes problemas a ineficiência de práticas operacionais; falta de manutenção nos serviços, tanto preventiva quanto corretiva; carência na medição de consumo, muitas vezes inexistente, ocorrendo também em muitos casos onde as contas de água são baseadas no tamanho e valor da propriedade, desconsiderando a quantidade de água consumida; destaca também a ausência de responsabilidade na regulação dos serviços por parte das instituições.

$\mathrm{Na}$ reflexão aqui efetivada, destaca-se que muitas autoridades têm procurado caminhos alternativos para proporcionar serviços mais eficientes de água e esgoto. $\mathrm{E}$, por parte de alguns governantes, tem crescido a opinião de que algumas ou todas as funções relacionadas com os serviços de água e esgoto devem ficar na incumbência da iniciativa privada.

Por isso mesmo é preciso que a regulamentação do saneamento seja estabelecida em âmbito nacional, para não ficar à mercê de regulamentos aleatórios em que cada empresa faz o seu regulamento. Primeiro, é necessário 
e mesmo urgente que a população receba serviços de qualidade. Segundo, antes de um eventual predomínio da iniciativa privada na gestão e execução destes serviços, é importante ter uma regulamentação nacional.

Em termos de gestão dos serviços de saneamento, segundo BAU (1996a;1996b), o modelo é bom se ele serve à política que está definida no momento e é ruim se ele não serve a essa política. Portanto, o ponto central da discussão não é o modelo, mas sim os aspectos que são considerados numa política de saneamento, tais como: necessidade de recursos financeiros para investimentos, necessidade de pessoal devidamente capacitado e treinado, tecnologias apropriadas, dentre outros.

A discussão aprofunda também as questões de qualidade de vida, como registrado na Conferência Nacional de Saneamento em 1999, destacando: "Não há dúvida de que é possível melhorar a qualidade de vida da população com mais autonomia financeira do município em relação aos demais entes da federação, mesmo porque torna-se maior a visibilidade dos projetos urbanos e mais consistente o planejamento" (CNS 1999, p.33).

Debates em conferências, congressos e experiências práticas têm colocado que o caminho para solucionar os problemas que afligem os grandes centros urbanos e cidades de médio porte tem sido a descentralização da gestão, em que o poder local deve assumir cada vez mais suas ações nessa área. No entanto, LEVY (1993) destaca que se deve tomar algumas medidas para que esse processo de descentralização ocorra com sucesso. Assim, por exemplo, diz que é importante que ocorra a transferência de alguns poderes com clareza de responsabilidades, pois, se isso não ocorrer, haverá conflitos de atuação, emperrando a implementação de programas e projetos. No caso de terceirização, essa responsabilidade deve ficar bem estipulada, pois também ocorre mudança no perfil do funcionalismo, na medida em que funções relacionadas à produção de serviços são remetidas para o mercado de trabalho. 
SERVA (1993) salienta o fato de que as empresas prestadoras de serviços públicos controladas pelos governos estaduais são geralmente desconectadas dos órgãos das administrações municipais. Isto leva a intervenções bastante desordenadas.

Focalizando o poder local que recebe essa descentralização, observa-se que "A implantação de projetos locais, pelo contato direto com as demandas populares, fomenta uma relação direta com os cidadãos, valorizando a organização e o controle social. Permite, assim, a construção do poder popular, possibilidade do sonho de uma sociedade justa, democrática e feliz" (SABESP 2000, p.8).

Por outro lado, há autores como FISCHER (1993, p.10) que mostram que "A noção do local contém duas idéias complementares em um sentido e antagônicas em outro. Se o local refere-se a um âmbito espacial delimitado e pode ser identificado como base, território, macrorregião e outras designações que sugerem constância a uma certa inércia, contém igualmente o sentido de espaço abstrato de relações sociais que se quer privilegiar e, portanto, indica movimento e interação de grupos sociais que se articulam e se opõem em torno de interesses comuns".

Quanto ao fenômeno do poder em si, este é definido como a capacidade ou a possibilidade de agir, de produzir efeitos. Analisado no sentido das relações sociais, o poder pode ser entendido, tanto como a capacidade geral de agir, quanto como a capacidade de produzir comportamentos específicos (FISCHER apud STOPPINO 1987). Por isso, pode-se dizer que "O poder tem, portanto, um caráter relacional recíproco, mas há atores que exercem o poder enquanto outros a ele se submetem" (FISCHER 1993 p.12).

Embora a Constituição Federativa do Brasil de 1988 estabeleça, em seu artigo 30, que "compete aos municípios legislar sobre assuntos de interesse local", bem como "organizar e prestar, diretamente ou sob regime de concessão ou permissão, os serviços públicos de interesse local (....)" (BRASIL 1999), há uma lacuna a respeito da titularidade da competência para a 
prestação desses serviços e nesse aspecto é que o processo de discussão sobre a gestão dos serviços de saneamento está em pleno vapor, através do Projeto de Lei 4147, de 2001. Esse Projeto de Lei institui as Diretrizes Básicas Nacionais para a Prestação dos Serviços Públicos de Saneamento Básico. O foco de atenção está voltado para os municípios de médio e grande porte, pois não houve ainda consenso sobre alguns aspectos importantes de que trata 0 Projeto, como a questão da titularidade dos serviços para os casos de Regiões Metropolitanas ou de aglomerações de municípios com peculiaridades de suas regiões. O que tem sido apontado nas discussões desse Projeto de Lei é que os municípios poderão perder a autonomia e perder o poder de concessão sobre o saneamento, atribuições conferidas pela Constituição Federal de 1988. Os municípios, por sua vez, não querem perder a titularidade sob esses serviço. A discussão atinge o seu ápice.

Assim é que há outras opiniões. Segundo WALD (2000), a Constituição Brasileira não atribui expressamente a nenhum ente federativo a competência para a prestação dos serviços públicos de saneamento básico, nem define quem é o poder concedente. Estes serviços, afirma o jurista, são tidos como de interesse local e, nesse sentido, estão inseridos no âmbito da competência local.

Como se vê, os conflitos em torno dessa discussão do Projeto de Lei 4147/2001 por vezes traduzem opiniões antagônicas. Há aqueles que defendem a questão municipalista e há aqueles que defendem a questão estadista.

Ampliando essa visão, observa-se que há autores que entendem que o poder do município está limitado por questões financeiras, como diz CARNEIRO (1994) "um dos maiores desafios para o exercício da autonomia municipal é adquirir a plena capacidade para tomar empréstimos sem qualquer aval da União e dos Estados e sem qualquer intermediação".

O que se depreende é que não se trata do fato de não se dispor de recursos financeiros, mas sim de se priorizar critérios para obtê-los e aonde 
aplicá-los. No Brasil, os recursos financeiros para o setor de saneamento são provenientes principalmente do Orçamento da União e do Fundo de Garantia por Tempo de Serviço. Isto leva a crer que o problema das deficiências existentes no setor não está na falta de recursos, mas na forma de administrálo e nos critérios para o estabelecimento de prioridades de sua aplicação. Vivese um cenário bastante nebuloso por isto mesmo, que impede os municípios de obterem verbas para saneamento básico (ANONYMUS 1999).

REZENDE (1994, p.15-17) chama a atenção quando diz que "a distribuição de recursos públicos per capita no Brasil não guarda relação com a pobreza regional e nem com a pobreza dos municípios em si”. Sabe-se também que a dinâmica econômica e demográfica, caminha em direção oposta, pois concentra as demandas, principalmente as de saneamento básico, nas áreas metropolitanas e cidades de porte médio, locais esses que, pelo número de população não atendida em suas periferias, tendem a um perfil epidemiológico preocupante. Essa é uma grande contradição ao pensamento de Rezende.

Desse modo, tanto municípios pobres, como ricas regiões metropolitanas ou cidades de porte médio e grande com extensas periferias pobres, têm perfil epidemiológico problemático. Daí a importância de analisar a gestão dos serviços de água e esgoto em municípios de grande porte do Estado de São Paulo. Mas, ainda no contexto brasileiro, as populações pobres vêm migrando intensamente para os grandes centros urbanos à procura de meios de sobrevivência. Por outro lado, áreas metropolitanas que passaram pelo forte processo de urbanização, no período de 1970 - 1980, hoje estão passando por uma forte desconcentração de atividades como a industrial, especialmente nos Estados do Rio de Janeiro e São Paulo. Conforme explica HOGAN (2000), as metrópoles desses Estados tiveram forte concentração populacional, no contexto estadual, ao longo dos últimos cinqüenta anos. $E$ para onde estão migrando essas populações? Estão migrando para os municípios vizinhos a essas regiões metropolitanas. No caso da Região Metropolitana de São Paulo, os municípios do interior paulista é que estão 
recebendo, provavelmente, essas populações, pois a taxa de crescimento populacional da Região Metropolitana de São Paulo passou de 4,5\% a.a. no período 1970 - 1980, para 1,9 \% a.a. nos anos de 1980, enquanto o interior paulista cresceu, no período 1980 - 1991 à taxa de 2,4 \% a.a., portanto a índices mais elevados que a Região Metropolitana de São Paulo. (HOGAN 2000). Esse processo naturalmente demanda novas áreas para absorver essas populações e, consequentemente, infra-estruturas que permitam um desenvolvimento dentro de uma condição básica de qualidade de vida.

Assim sendo, muitas vezes, as cidades não estão preparadas para receber de maneira emergencial as populações migrantes e nem têm infraestruturas que suportem tal processo.

Daí o desafio desta tese em analisar a gestão dos serviços de água e esgoto em quatro municípios de grande porte do Estado de São Paulo. Os municípios selecionados foram: Campinas, Santo André, São José dos Campos e Santos. Nos Municípios de Campinas e Santo André, a gestão desses serviços encontra-se na esfera de governo municipal. Já nos Municípios de São José dos Campos e Santos, a gestão encontra-se na esfera de governo estadual.

Uma vez selecionados os municípios, o passo seguinte foi refletir sobre a hipótese: se há diferenças na eficiência e na eficácia da gestão desses serviços, quando se trata de esfera de governo estadual ou municipal; e na existência, ou não, de políticas públicas e políticas de governo que contemplem esses serviços. Nesse sentido as perguntas elaboradas para demonstrar essa hipótese foram:

a) Há diferenças em termos de eficácia e de eficiência entre a gestão dos serviços de água e esgoto nos municípios estudados, quando estes estão sob responsabilidade do governo estadual ou do governo municipal?

b) Em caso positivo, em que aspectos e em que âmbito de governo estas diferenças se apresentam? Em relação a esses aspectos, entenda-se os aferidos por indicadores, tais como, população atendida por água, população atendida por esgotamento sanitário e aumento no tratamento de 
esgoto. Em relação ao âmbito desses serviços, procura-se focalizar a responsabilidade estadual e a municipal na gestão desses serviços.

c) Existe correspondência entre o que é declarado nas leis com o que é efetivamente praticado pelos governantes e(ou) gestores desses serviços?

Para responder a essas questões e demonstrar a hipótese desta tese, o caminho percorrido foi, primeiro, conhecer a gestão dos serviços de água e esgoto em cada um dos quatro municípios e as relações entre as esferas de governo estadual e municipais, levantando indicadores que permitissem analisar a gestão municipal e estadual desses serviços naqueles municípios. Em seguida, passou-se a analisar as políticas públicas relacionadas ao saneamento e as políticas públicas de desenvolvimento correlacionadas, de âmbito nacional, estadual e municipal. Finalmente, foram analisadas as políticas de governo de cada município, no período 1996 - 2000. Os passos referentes a esse caminho percorrido estão descritos no item 3 Método. Já os resultados, bem como as análises, estão apresentados no item 4 Resultados da Pesquisa.

Assim sendo, foi possível discutir as diferenças na eficiência e na eficácia da gestão dos serviços de água e esgoto em relação ao comando municipal e estadual, que estão apresentadas no item 5 Discussão dos Resultados. Assim é que, dando sequêencia aos procedimentos metodológicos, apresentam-se os objetivos que nortearam este trabalho. 


\section{Objetivos}

\subsection{Objetivo geral}

Analisar a gestão dos serviços de água e esgoto nos municípios de Campinas, Santo André, São José dos Campos e Santos, no período de 1996 a 2000, visando demonstrar diferenças na eficiência e na eficácia das gestões estadual e municipal.

\subsection{Objetivos específicos}

- Conhecer formas de administração dos serviços de água e esgoto no Brasil.

- Identificar e analisar políticas públicas no âmbito nacional, do Estado de São Paulo e dos municípios, relacionadas ao saneamento básico - água e esgoto.

- Conhecer a gestão dos serviços de água e esgoto nos municípios de Campinas, Santo André, São José dos Campos e Santos.

- Identificar e analisar políticas de governo, voltadas ao saneamento básico água e esgoto -, desses municípios no período 1996 a 2000. 


\section{Método}

Os métodos adotados para comprovar a hipótese desta tese foram: seleção dos municípios, pesquisa bibliográfica, documental, aplicação de questionários, investigação explicativa fundamentada pela teoria, seguida de análise dos resultados.

Optou-se por esses métodos após conhecer alguns autores que tratam de questões metodológicas, como GIL (1994 e 1995), RUDIO (1999), VERGARA (1990), SEVERINO (1999), THIOLLENT (1994) ALVES-MAZZOTTI e GEWANDSZNAJDER (1999) e KOCHE (1999), adotando como referencial para a escolha do tipo de pesquisa os ensinamentos de VERGARA (1990). Essa autora expõe dois critérios básicos para a escolha de pesquisa que são: quanto aos fins e quanto aos meios. A pesquisa quanto aos fins pode ser do tipo: exploratória; descritiva; explicativa; metodológica; aplicada e intervencionista. Já em relação aos meios de investigação, a pesquisa pode ser do tipo: pesquisa de campo, pesquisa de laboratório, documental, bibliográfica, experimental, ex post facto, participante, pesquisa - ação e estudo de caso.

Após o conhecimento de cada um desses tipos de pesquisa, a bibliográfica e documental, quanto aos meios, foram os que mais se identificaram com a natureza desta tese e, quanto aos fins, foi a pesquisa explicativa.

A opção pela pesquisa bibliográfica deveu-se ao fato de possibilitar o conhecimento do estado da arte, o referencial teórico para construir a lógica da pesquisa e a discussão das principais questões. Conforme diz ALVESMAZZOTTI E GEWANDSZNAJDER (1999), "o esforço de elaboração teórica é essencial, pois o quadro referencial clarifica a lógica de construção do objeto da pesquisa, orienta a definição de categorias e constructos relevantes e dá suporte às relações antecipadas nas hipóteses, além de constituir o principal instrumento para interpretações dos resultados da pesquisa". Portanto, a literatura revista, apresentada no item 1 , foi tomada como referencial teórico. 
Em relação à opção pela pesquisa documental, esta deveu-se à natureza do tema pesquisado, no qual a maioria dos documentos encontra-se no interior dos órgãos gestores, nas Câmaras Municipais e nas prefeituras.

No que tange à opção pela aplicação de questionários, esta deveu-se à busca por informações quantitativas e qualitativas que na maioria das vezes não está disponibilizada, na literatura, numa série histórica condizente com a da pesquisa.

Finalmente, a pesquisa explicativa foi escolhida, no sentido de justificar diferenças na eficiência e na eficácia da gestão municipal e estadual dos serviços de água e esgoto, após conhecimentos teóricos obtidos pela pesquisa bibliográfica, documental, informações dos questionários e análise dos resultados. A investigação explicativa pressupõe pesquisa descritiva, pois visa descobrir e observar fenômenos e então classificá-los, descrevê-los e interpretá-los (RUDIO 1999).

Assim sendo, esses métodos ora apresentados foram julgados os mais apropriados para o desenvolvimento deste trabalho. Antes de adentrar os métodos propriamente ditos, fez-se necessário conhecer e conceituar os termos eficiência e eficácia para esta tese. Assim, o que é eficiência e eficácia?

Eficiência é "ação, capacidade de produzir um efeito" e Eficácia é "qualidade daquilo que produz o resultado esperado" (MICHAELIS 2002).

TENÓRIO (1997), quando discute que gerenciar é estabelecer objetivos e alocar recursos para atingir finalidades determinadas, coloca que esta gerência deve ser avaliada a partir de medidas de eficiência e eficácia e define que eficiência "é a melhor forma de fazer algo com os recursos disponíveis" e eficácia "é fazer o que deve ser feito, isto é, cumprir o objetivo determinado."

Já para LIMA (2000), eficiência "tem a ver com os processos, procedimentos, rotinas, a forma de fazer bem as coisas, a utilização do tempo e dos recursos e a eficácia é o resultado da decisão acertada, a orientação das ações, planos e programas na consecução dos objetivos (....) diz respeito ou 
depende da estratégia a ser seguida quanto ao uso do tempo, alocação de recursos (....)".

Aplicando conceitos desses diferentes autores e conceituando-os para o desenvolvimento dessa tese, adotou-se que a eficiência da gestão dos serviços de água e esgoto se dá quando o responsável por esses serviços e(ou) os governantes dos municípios estabelecem programas, projetos, obras e atividades, para que recursos sejam aplicados no sentido de levar água de boa qualidade e em quantidade suficiente à população, e coletar e tratar os efluentes, minimizando a poluição dos recursos hídricos e aumentando a qualidade de vida urbana.

Quanto à eficácia da gestão dos serviços de água e esgoto, ela ocorre quando se tem resultados sociais, ou seja, quando a população usufrui da água e dos serviços de esgoto, com nítida conseqüência em termos de abrangência dos serviços, incluindo um número cada vez maior de habitantes, tanto em termos de cobertura de água, como de coleta e tratamento de esgoto.

Definidos os termos, passa-se a apresentar os procedimentos metodológicos para a seleção dos municípios, pesquisa bibliográfica, documental, explicativa, bem como os procedimentos adotados para a realização das análises, comparações e interpretações voltadas a demonstrar a hipótese anteriormente citada. Assim, destacam-se os tópicos que serão apresentados na seqüência.

- Critérios e procedimentos para a seleção dos municípios estudados, ou seja, Campinas, Santo André, São José dos Campos e Santos. Para tanto, são apresentadas neste item a classificação para o porte de municípios e formas de administração dos serviços públicos no Brasil, as quais nortearam a seleção desses municípios e também a justificativa em relação ao recorte temporal para o desenvolvimento desta tese;

- Procedimentos adotados para a pesquisa bibliográfica; procedimentos adotados para a identificação das políticas públicas nacionais, do Estado de São Paulo e dos municípios de Campinas, Santo André, São José dos 
Campos e Santos, correlacionadas com a gestão dos serviços de água e esgoto;

- Procedimentos adotados para a realização da pesquisa documental; procedimentos adotados para a identificação de políticas de governo estadual e municipais de Campinas, Santo André, São José dos Campos e Santos, voltadas ao saneamento básico no período de 1996-2000;

- Procedimentos para a aplicação dos questionários;

- Levantamento de indicadores de avaliação da gestão dos serviços de água e esgoto no âmbito nacional e no âmbito do Estado de São Paulo;

- Procedimentos para a realização da investigação explicativa, e

- Procedimentos para a forma de análise dos resultados da pesquisa que possibilitaram demonstrar a eficiência e eficácia da gestão estadual e municipal dos serviços de água e esgoto.

\subsection{Critérios e procedimentos para seleção dos municípios}

Para selecionar os municípios de grande porte do Estado de São Paulo, buscou-se conhecer como o Instituto Brasileiro de Geografia e Estatística IBGE os classificava, ou seja, quando os municípios são considerados de grande porte? Verificou-se que o IBGE não possuía uma classificação específica que agrupasse os municípios segundo seu porte. $\mathrm{Na}$ literatura encontra-se a definição de BARROS (1999), que apresenta, porém, as seguintes faixas de município, conforme sua população:

localidades urbanas com até 20.000 habitantes - pequeno porte; localidades urbanas de 20.001 a 100.000 habitantes - porte intermediário; localidades urbanas de 100.001 a 500.000 habitantes - médio porte; e, localidades urbanas com mais de 500.001 - grande porte.

Analisando esta classificação, observa-se que o município de pequeno porte se iguala àquele considerado pela Constituição Federal de 1988, que obriga somente municípios com população superior a 20.000 habitantes a terem Planos Diretores. As faixas seguintes, até 100.000 habitantes e 500.000, foram consideradas de porte médio. Desse modo, de acordo com os objetivos 
desta tese, acolheu-se a última faixa, constituída por municípios com população ao redor de 500.000 habitantes ou superior. Assim, os municípios selecionados foram considerados de grande porte, e dentre esses os que atingem este porte pela contabilização também da população flutuante, como o município de Santos.

Dando continuidade aos procedimentos metodológicos, buscou-se conhecer formas de administração dos serviços públicos no Brasil, visando o entendimento sobre as questões de subordinação da gestão dos serviços de água e esgoto. Portanto, no que se refere a esfera de governo sob a qual está o comando da gestão dos serviços de água e esgoto, foram priorizados os aspectos administrativos. Por isto consultou-se o IBAM (1967), que distingue de duas formas os serviços públicos: via direta, através dos próprios órgãos da administração pública, ou indiretamente, por meio de autarquias e entidades paraestatais, como sociedades de economia mista, empresas públicas e fundações.

As autarquias são órgãos da administração, criados por lei para a realização de objetivos determinados, com personalidade jurídica de direito público, patrimônio próprio, autonomia administrativa e financeira pois, ainda que como órgãos autônomos, sujeitam-se à supervisão do poder público que controla seus atos também por meio dos tribunais de contas.

As entidades paraestatais têm também sua criação autorizada por lei, visando a realização de serviços específicos, de interesse público, como a SANASA e a SABESP. No entanto, como entidades de direito privado, recebem atribuições estatais por delegação. Já as fundações, criadas pelo Estado, podem estar submetidas a um ou outro sistema, direto ou indireto, de administração, conforme dispuser a lei que autoriza sua instituição (IBAM 1967).

Ressalta-se então que somente por lei específica poderá ser criada a autarquia e autorizada a instituição de empresa pública, de sociedade de economia mista e de fundação, cabendo à lei complementar, neste último caso, 
definir as áreas de sua atuação, conforme Constituição Federativa de 1988 art.37 inciso XIX (Brasil 1999).

Assim, de acordo com estas considerações, optou-se por distinguir:

(a) municípios que exercem a gestão local;

(b) municípios que são subordinados à gestão estadual.

Desse modo, no caso (a), cujo comando da gestão está no âmbito local, foram adotados ainda os seguintes critérios:

- o município deve pertencer ao Estado de São Paulo;

- o município deve ter gestão dos serviços de água e de esgoto no âmbito municipal;

- o município deve ser cadastrado na ASSEMAE - Associação Nacional dos Serviços Municipais de Saneamento; e

- o município deve ter população maior que 500.000 habitantes.

Segundo esses critérios, os municípios selecionados para a pesquisa foram Campinas e Santo André, conforme estudos efetuados e apresentados a seguir.

O Brasil têm 1.700 municípios cuja gestão dos serviços de água e esgoto é realizada no âmbito municipal, ou seja, local. Desses 1.700 municípios, 963 são cadastrados na ASSEMAE, e destes foram selecionados aqueles pertencentes ao Estado de São Paulo, tendo-se encontrado 273 municípios. Finalmente, destes 273 municípios paulistas cadastrados na ASSEMAE, foram selecionados aqueles com população superior a 500.000 habitantes, tendo-se encontrado 5 municípios: Campinas, Guarulhos, São Bernardo do Campo, Santo André e Osasco. Destes 5, por motivos de tempo e recursos, optou-se por selecionar o mais antigo exemplo de gestão municipal Campinas - e o pioneiro em gestão integrada dos serviços municipais (água, esgoto, drenagem, resíduos sólidos, meio ambiente), vide item 4.2.2 - Santo André. 
A gestão dos serviços de água e esgoto do município de Campinas é de responsabilidade da SANASA - Sociedade de Abastecimento de Água e Saneamento S.A. - Sociedade de economia mista de capital aberto e direito privado, sendo seu principal acionista a Prefeitura de Campinas. Quanto ao município de Santo André, a responsabilidade da gestão desses serviços é do SEMASA - Serviço Municipal de Saneamento Ambiental - autarquia de direito público.

A seleção dos municípios cujo comando da gestão está no âmbito estadual, caso (b), foi feita observando os seguintes critérios:

- o município deve pertencer ao Estado de São Paulo;

- o município deve ter a gestão dos serviços de água e de esgoto sob responsabilidade do Estado; e

- o município deve ter população maior que 500.000 habitantes, incluindo a população flutuante.

Nestas condições foram encontrados dois municípios. São José dos Campos e Santos, conforme estudos efetuados e apresentados a seguir.

O Estado de São Paulo tem 645 municípios. Destes, 366 têm a gestão dos serviços de água e esgoto administrada no âmbito estadual. Dos 366 municípios, foram selecionados aqueles com população acima de 500.000 habitantes, considerada a população flutuante. Desse modo, foram encontrados três municípios: São Paulo, São José dos Campos e Santos. O município de São Paulo foi descartado pois apresenta população maior que 10 milhões de habitantes, muito acima dos demais municípios selecionados, não servindo como parâmetro de análise para o estudo. Assim, os dois municípios selecionados para a pesquisa foram São José dos Campos e Santos. A gestão dos serviços de água e esgoto nos municípios de São José dos Campos e Santos é de responsabilidade da SABESP - Companhia de Saneamento Básico do Estado de São Paulo - empresa de economia mista de capital aberto e direito público, sendo seu principal acionista o governo do Estado de São Paulo. 
Observa-se, assim, que os municípios selecionados para a análise da eficiência e eficácia da gestão municipal e estadual dos serviços de água e esgoto são: Campinas, Santo André, São José dos Campos e Santos. E em que período está centrada a análise?

A análise está centrada no período de 1996-2000, ou seja, em um período de 5 anos. Escolheu-se esse período, visando contemplar 2 gestões administrativas de governo, tanto municipal quanto estadual. Por outro lado, esse período foi o mais recente para a pesquisadora, uma vez que a aplicação dos questionários de cada município iniciou-se no ano de 2001. Portanto, após a seleção dos municípios e da definição do recorte temporal, partiu-se para a pesquisa bibliográfica, conforme segue.

\subsection{Pesquisa bibliográfica}

Buscou-se, inicialmente, conhecer o estado da arte em relação à gestão do saneamento básico no Brasil, tais como, a estruturação do saneamento desde a década de 1930 até a década de 2000; formas de administração existentes para os serviços públicos; e o panorama sobre o saneamento básico nas regiões brasileiras. Buscou-se, ainda, estudar outras literaturas necessárias ao entendimento do tema, como, poder local, participação pública, gestão pública, políticas públicas, políticas de governo, eficiência, eficácia, entre numerosas outras listadas no item 7 Bibliografia.

Necessário se fez conhecer, também na literatura internacional, a gestão do saneamento em alguns países como Estados Unidos da América, Portugal, França, Inglaterra, Argentina e Colômbia.

Assim sendo, para a pesquisa bibliográfica, realizou-se uma busca minuciosa sobre a produção de pesquisas anteriores, sobre o tema gestão do saneamento ambiental e os temas correlatos como, meio ambiente, saúde, recursos hídricos, poder local, desenvolvimento urbano, políticas públicas, participação da sociedade e outros necessários aos desdobramentos do assunto. Esta investigação foi efetuada em teses de doutorado, dissertações 
de mestrado, artigos de revistas técnicas e científicas nacionais e internacionais, livros, anais de congressos e jornais técnicos da área. Além disso, realizou-se investigações nas bibliotecas da Faculdade de Saúde Pública - FSP da USP, CETESB, SABESP, SANASA, SEMASA, Faculdade de Arquitetura e Urbanismo - FAU da USP, Fundação Getúlio Vargas, Universidade Estadual de Campinas - UNICAMP, Prefeitura de Campinas, Câmara de Vereadores do Município de Santo André, em acervo técnico do orientador, acervo de profissionais da área de meio ambiente e de governos locais, bem como por meio de intercâmbio com profissionais e pesquisadores em congressos nacionais e internacionais, que aconteceram durante 0 desenvolvimento desta tese. Na biblioteca da FSP/USP, foi utilizada a base Dedalus, Banco de Dados Bibliográficos da USP, que reúne informações sobre os acervos das bibliotecas do Sistema Integrado de Bibliotecas da USP. Foram utilizadas, também, as bases de dados da Repidisca - Rede de Informações em Saúde Ambiental, LILACS e PAHO. Em relação à pesquisa bibliográfica internacional sobre gestão de serviços de saneamento, foram adquiridas diversas publicações por meio de pesquisa nas bases de dados Repidisca, Bireme/OPAS/OMS (Centro Latino Americano e do Caribe de Informações em Ciências da Saúde) e ASFA-Aquatic Science \& Fisheries ABS, as quais recuperam trabalhos na América Latina, Caribe, USA, Europa e Ásia, dentre outros.

Ainda em relação à literatura pesquisada, destacam-se legislações de saneamento e correlatas ao tema. Essas legislações foram analisadas no sentido de identificar políticas públicas voltadas à gestão dos serviços de água e esgoto, no âmbito nacional, estadual e para os municípios de Campinas, Santo André, São José dos Campos e Santos.

Mas o que são políticas públicas? Segundo PHILIPPI Jr e BRUNA 2002, política pública é o "conjunto de diretrizes estabelecido pela sociedade, por meio de sua representação política, em forma de lei, visando a melhoria de condições de vida dessa sociedade. A iniciativa da implementação de uma política pública tanto pode partir do governo quanto da sociedade". 
A partir disso, depreende-se que a política pública é aquela promulgada pelo legislativo e sancionada pelo executivo, em seus respectivos âmbitos de governo, seja pela Câmara de Vereadores, pela Assembléia Legislativa, ou pelo Congresso Nacional. Está apresentada em forma de leis as quais devem ser cumpridas pela gestão de governo, independente do partido político a qual pertença. Portanto, para a identificação das políticas públicas voltadas ou correlacionadas ao saneamento básico, foram escolhidas legislações federal, do Estado de São Paulo e dos municípios de Campinas, Santo André, São José dos Campos e de Santos.

No caso da Legislação Federal, foram estudadas a Constituição Federal, a Política Nacional de Meio Ambiente, a Política Nacional de Saúde e a Política Nacional de Recursos Hídricos.

Já para a legislação do Estado de São Paulo, foram estudadas a Constituição do Estado, a Política Estadual de Saneamento e a Política Estadual de Recursos Hídricos.

A escolha dessas legislações foi, num primeiro momento, pela relação com o saneamento básico e, num segundo momento, pela relação mais estreita com os serviços de água e esgoto. A partir disto, buscou-se identificar os artigos que remetem responsabilidades aos estados e aos municípios, no sentido de promover a autonomia em relação ao saneamento básico e, buscouse principalmente identificar nessas legislações os artigos relacionados ao saneamento básico. Quanto à legislação municipal, para a identificação das políticas públicas, voltadas ao saneamento básico, foram utilizados os seguintes instrumentos: leis orgânicas, planos diretores e algumas políticas públicas municipais voltadas ao saneamento básico. Nesses instrumentos, buscou-se identificar os artigos com estreita relação com o saneamento básico - água e esgoto. Esses procedimentos possibilitaram destacar diretrizes estabelecidas nos artigos dessas leis, as quais foram tomadas como parâmetros qualitativos na análise da eficiência e eficácia da gestão estadual e municipal desses serviços. 
Em relação à escolha pelas leis orgânicas, planos diretores, têm-se que:

> A lei orgânica foi escolhida como instrumento de análise, pois estabelece princípios e diretrizes da organização do município, sendo de caráter obrigatório, instituída pela Constituição Federal de 1988, em seu artigo 29. Assim, buscou-se identificar as diretrizes de cada município em relação ao saneamento básico.

Já a escolha do Plano Diretor, deveu-se ao fato de ser um instrumento básico da política de desenvolvimento e expansão urbana, além de obrigatório para municípios com mais de 20.000 habitantes, de acordo a Constituição Federal de 1988, em seu artigo 182, possibilitando verificar desse modo as diretrizes estabelecidas para o saneamento básico em cada município.

Quanto ao levantamento das demais leis municipais, escolheram-se aquelas com estreita relação aos serviços de água e esgoto, encontrando, dessa maneira, somente para o município de Santo André, a Política Municipal de Gestão e Saneamento Ambiental.

Dessa forma, esse conjunto de leis foi julgado o mais pertinente para o desenvolvimento desse trabalho do ponto de vista da pesquisadora.

Esses documentos foram encontrados na internet em sites, tais como, dos Ministérios do Meio Ambiente, da Saúde, do Planejamento, das Secretarias de Meio Ambiente, da Saúde, de Recursos Hídricos e de Planejamento do Estado de São Paulo, da EMPLASA e da SABESP, bem como nos sites da prefeituras, secretarias municipais e órgãos responsáveis pelos serviços de água e esgoto nos respectivos municípios. Com relação aos planos diretores, no município de Santos, este foi obtido na Secretaria Municipal do Planejamento. Para o município de Campinas, no Centro de Documentação da SANASA. Para o Município de São José dos Campos, foi obtido por meio da Secretaria de Planejamento e, em Santo André, via internet. 


\subsection{Pesquisa documental}

De acordo com VERGARA (1990), a investigação documental é "realizada em documentos conservados no interior de órgãos públicos e privados de qualquer natureza ou pessoas". Nesse sentido e, como dito anteriormente, esta forma de pesquisa possibilitou o conhecimento da maioria dos documentos nos órgãos gestores dos serviços e daqueles da administração municipal e estadual, muitas vezes não disponibilizados em bibliotecas públicas e outras formas como internet e publicações de grande circulação. Assim, essa pesquisa documental buscou conhecer a gestão de cada um dos quatro municípios e demais aspectos necessários para o desenvolvimento da pesquisa, como informações gerenciais, operacionais e técnicas encontradas nos documentos pesquisados.

Desse modo, foram estudados os documentos existentes nas bibliotecas dos órgãos responsáveis pelos serviços de água e esgoto dos municípios de Santo André e Campinas, visando conhecer a história da gestão dos serviços de água esgoto de cada um deles. Para os municípios de Santos e São José dos Campos, a pesquisa documental foi realizada na biblioteca da SABESP de São Paulo, uma vez que esses municípios, operados pela a SABESP, não possuem bibliotecas descentralizadas. Nessa biblioteca, não foram encontrados documentos que contemplassem a história da gestão dos serviços de água e esgoto anterior à administração da SABESP para as cidades de Santos e de São José dos Campos. Neste caso, para obter o histórico da gestão desses serviços na cidade de Santos, foram consultados técnicos da SABESP - Santos e, na cidade de São José dos Campos, recorreu-se à Fundação Ricardo Cassiano, cujo acesso demandava tempo não disponível.

A pesquisa documental possibilitou também a identificação de políticas dos governos estadual e municipais, relacionadas à gestão dos serviços de água e esgoto, para os municípios de Campinas, Santo André, São José dos Campos e Santos, no período de 1996-2000. 
Mas o que são políticas de governo? Segundo PHILIPPI Jr e BRUNA (2002), política de governo é o conjunto de diretrizes estabelecido pela administração pública, sendo que os planos, programas e projetos de cada gestão administrativa, na maioria das vezes representa os anseios do partido político. Portanto, para a identificação das políticas de governo dos municípios de Campinas, Santo André, São José dos Campos, Santos e do Estado de São Paulo, voltadas ao saneamento básico, para o período de 1996-2000, foram escolhidos os seguintes instrumentos: os Planos Plurianuais, Leis de Diretrizes Orçamentárias e as Leis Orçamentárias Anuais. Esses instrumentos foram instituídos pela Constituição Paulista de 1989 e leis orgânicas com base na Constituição Federal de 1988.

Além desses instrumentos, buscou-se analisar também o planejamento estratégico dos operadores do sistema de água e esgoto para os 4 municípios, no intuito de identificar de forma mais detalhada, do ponto de vista da organização, as diretrizes estratégicas, metas e resultados para o saneamento básico que foram tomados como parâmetros de políticas de governo para a análise dos resultados. Ainda em relação aos operadores dos sistemas de água e esgoto, foram analisados os orçamentos anuais da SANASA Campinas e SEMASA - Santo André. Já para São José dos Campos e Santos, os Planos Plurianuais de Investimentos da SABESP não foram disponibilizados.

Escolheu se o Plano Plurianual pois este estabelece diretrizes, objetivos e metas da administração municipal, onde as prioridades do governo são estabelecidas por um período de quatro anos. Nesse sentido, buscou-se identificar nesse instrumento metas e prioridades estabelecidas para 0 saneamento básico em cada um dos quatro municípios, servindo de indicadores de políticas de governo. Uma vez que o Plano Plurianual é estabelecido para quatro anos, contemplando sempre o segundo ano de uma gestão administrativa e o primeiro ano da gestão seguinte e, que esse trabalho abrange cinco anos, foi necessário estudar dois planos para cada município, ou seja, o quadriênio 1994-1997 e o quadriênio 1998-2001. 
A opção pela Lei de Diretrizes Orçamentárias se deve ao fato de que esta dispõe sobre as diretrizes gerais que visam orientar a elaboração do orçamento do município e estabelece as metas e prioridades para o exercício financeiro do ano subsequente do município. Assim, buscou-se identificar nessa Lei as diretrizes estabelecidas anualmente para o saneamento básico para cada um dos quatro municípios, tomados como parâmetros de políticas de governo. Essa lei retrata na maioria dos casos o que está estabelecido nos planos plurianuais.

Já a escolha da Lei Orçamentária Anual se deu por compreender o orçamento fiscal referente aos poderes do município, seus fundos, órgãos e entidades da administração direta e indireta a qual identificará os projetos e atividades, segundo a sua localização, dimensão, características principais, e custo. Nesse instrumento, buscou-se identificar para os quatro municípios o volume de recursos direcionado para o saneamento básico - água e esgoto, que também foram tomados como indicador de políticas de governo.

Finalmente, a escolha dos orçamentos anuais da SANASA, SEMASA e SABESP foi feita por possibilitar conhecimentos das diretrizes, metas, objetivos e volume de recursos para a gestão dos serviços de água e esgoto, de cada município, que foram tomados como parâmetros de políticas de governo para a análise dos resultados.

Em relação aos municípios de São José dos Campos e Santos, que são operados pela SABESP, buscou-se conhecer também os Planos Plurianuais de Investimentos dessa Companhia, visando identificar o volume de recursos direcionados à gestão dos serviços de água e esgoto para esses municípios. No entanto, como esse instrumento não foi disponibilizado e como essa Companhia está submetida à política do governo estadual e também recebe recursos desse governo, buscou-se identificar as políticas, para o saneamento básico, junto aos Planos Plurianuais do Governo Estadual, nas Leis de Diretrizes Orçamentárias e nas Leis Orçamentárias Anuais. Verificou-se que nesses instrumentos as diretrizes, metas e recursos não são estabelecidos de 
forma desagregada por município, como se esperava, para cobrir a lacunas de informações não alcançadas.

Assim, observa-se que foi realizado um amplo estudo dos planos plurianuais, das leis de diretrizes orçamentárias, das leis orçamentárias anuais e dos orçamentos anuais, para os municípios de Campinas, Santo André, São José dos Campos e Santos e para o Estado de São Paulo, relativos ao período de 1996 - 2000. No caso de Santos, efetuou-se a investigação na Secretaria Municipal de Economia e Finanças. Em relação a São José dos Campos, na Secretaria Municipal da Fazenda. No que tange a Santo André, a investigação foi realizada na Câmara Municipal, na assessoria do Prefeito e, no caso de Campinas, na biblioteca jurídica da Prefeitura.

Quanto à investigação desses instrumentos, para o Estado de São Paulo, foi realizada na internet no site da Secretaria de Planejamento do Estado e com profissionais dessa Secretaria. Obteve-se no site as Leis de Diretrizes Orçamentárias, as Leis Orçamentárias Anuais, os Orçamentos Anuais Consolidados e o Plano Plurianual do período 2000 a 2003. Quanto ao Plano Plurianual do período de 1996-1999, a informação obtida foi: "O Plano Plurianual do período que engloba os anos de 1996 a 1999 foi encaminhado à Assembléia Legislativa, porém o governador solicitou a retirada daquele plano e não retornou mais". Diante disto, o Plano Plurianual estudado foi apenas o do período de 2000 a 2003, que contemplou o ano 2000 para a pesquisa.

Finalmente, em relação à opção pela investigação do planejamento estratégico, deveu-se ao fato de ser uma ferramenta utilizada na maioria das instituições, a qual retrata a política daquele governante, definindo objetivos estratégicos, metas e mostrando os resultados atingidos. Foi detectada a existência de planejamento estratégico para a SANASA, em Campinas, e para - SEMASA, em Santo André. Já em relação ao planejamento estratégico da SABESP para São José dos Campos e Santos, as informações foram disponibilizadas apenas em relação à Companhia como um todo e não de forma desagregada para os municípios, o que impossibilitou a análise sobre eficiência e eficácia na gestão do órgão estadual da forma como foi feita para 
os Municípios de São José dos Campos e Santos. Os parâmetros para análise de políticas de governo da gestão estadual foram apenas os resultados quantitativos obtidos via questionário e banco de dados do SNIS.

Ainda em relação ao planejamento estratégico da SANASA e do SEMASA, estes foram disponibilizados de forma parcial, pois não foram encontrados os arquivos naquelas instituições para o período da pesquisa. Nos planejamentos estratégicos estudados, buscou-se identificar as metas de curto prazo que geralmente são de 4 anos e ainda verificar os resultados alcançados por esse planejamento, conforme podem ser observados no item 4.

Diante de tudo isso, foram identificados para o período 1996-2000, programas, projetos, metas, atividades e obras para o saneamento básico água e esgoto - estabelecidos pelos executivos e aprovados pelos legislativos, elencando-se desse modo as políticas de governo para cada município, conforme apresentadas no item 4. As diretrizes, objetivos, metas, projetos, atividades, volume de recursos para o saneamento extraídos dos Planos Plurianuais, Leis de Diretrizes Orçamentárias, Leis Orçamentárias Anuais, Orçamentos Anuais e do Planejamento Estratégico e também dos questionários respondidos pelos órgãos gestores dos serviços como índice de esgoto tratado, índice de cobertura de água e perdas físicas no sistema de abastecimento de água foram tomados como parâmetros qualitativos e quantitativos para medir a eficiência e eficácia da gestão municipal e estadual.

\subsection{Aplicação dos questionários}

Em relação aos questionários estes foram aplicados aos órgãos gestores dos serviços de água e esgoto nos 4 municípios, e foram aplicados em paralelo ao desenvolvimento da pesquisa bibliográfica e documental.

A opção por aplicar questionários nos órgãos gestores dos serviços de água e esgoto deveu-se ao fato de que: $1^{\circ}$ ) as informações quantitativas disponibilizadas nas publicações não cobriam o período de 5 anos da pesquisa, quando esta foi iniciada, como exemplo, investimentos direcionados para os 
sistemas de abastecimento de água e esgoto naquele período. $2^{\circ}$ ) por necessitar de informações qualitativas, que também não estavam disponíveis na literatura, como exemplo, relação e integração entre estado e municípios para o estabelecimento de políticas públicas, dentre outras.

As informações constantes das respostas dos questionários, como atendimento da população com água tratada, atendimento da população com coleta de esgoto, índice de esgoto tratado, entre outros, foram tomadas como parâmetros para a análise das diferenças de eficácia da gestão estadual e municipal dos serviços.

Assim, para o município de Campinas, aplicou-se o questionário na SANASA. Para o município de Santo André, no SEMASA. Nos municípios de São José dos Campos e Santos, em suas respectivas unidades da SABESP, passando pelo crivo da SABESP holding.

Antes de aplicar os questionários, foram feitos contatos com as diretorias dos órgãos responsáveis em cada município e que promoveram a apresentação dos dirigentes de cada um dos setores que auxiliaram com o preenchimento dos questionários e com o fornecimento de documentos que não estavam disponibilizados nas bibliotecas.

\subsection{Indicadores para avaliação dos serviços de água e esgoto no âmbito nacional e no âmbito do Estado de São Paulo}

Para a elaboração dos questionários, buscou-se conhecer os indicadores utilizados para avaliação dos serviços de água e esgoto no Brasil e no Estado de São Paulo, de que forma eles estão disponibilizados e, ainda, se cabiam para complementar a pesquisa.

Após levantamento e estudo sobre indicadores utilizados para a avaliação do serviços de água e esgoto no âmbito nacional e do Estado de São Paulo, foram encontrados os indicadores do Sistema Nacional de Informações em Saneamento - SNIS, da Caixa Econômica Federal - CEF, do Prêmio 
Nacional de Qualidade em Saneamento - PNQS e do Indicador de Salubridade Ambiental do Estado de São Paulo elaborado pelo Conselho Estadual de Saneamento - CONESAN. O que são e o que contemplam estes indicadores?

Em relação ao SNIS:

"O SNIS apoia-se em um banco de dados administrado na esfera federal e contém informações sobre a prestação de serviços de água e esgotos, de caráter operacional, gerencial e financeiro - inclusive dados de balanço $e$, ainda, informações sobre a qualidade dos serviços, atualizados anualmente desde 1995, para uma amostra extraída do universo de prestadores de serviços de todo o Brasil" (SNIS 2000).

"No âmbito federal, os dados destinam-se ao planejamento e à execução das políticas públicas, visando a orientar a aplicação de investimentos, a construção de estratégias de ação e o acompanhamento de programas, bem como a avaliação do desempenho dos serviços. Nas esferas estadual e municipal, esses dados contribuem para a regulação e o controle da prestação dos serviços e para a elevação dos níveis de eficiência e eficácia na gestão das entidades prestadoras dos serviços, por meio do conhecimento de sua realidade, orientando investimentos, custos e tarifas, bem como incentivando a participação da sociedade no controle da qualidade, monitorando e avaliando os efeitos das políticas públicas" (SNIS 2000).

Os diagnósticos resultantes do SNIS estão disponíveis na página [www.snis.gov.br]. Esse Sistema foi concebido pelo Governo Federal em 1995, no âmbito do Programa de Modernização do Setor Saneamento - PMSS comentado no item 1 Introdução.

O SNIS apresenta um conjunto de indicadores financeiros, operacionais e de gestão dos prestadores de serviços. Os indicadores financeiros contemplam: receita operacional, despesas totais, tarifas praticadas, investimentos nos sistemas de água e esgoto, índice de perdas de faturamento, dentre outros. Já os indicadores operacionais contemplam índice de atendimento de água, índice de atendimento de esgoto, quantidade de ligações de água, quantidade de ligações de esgoto, índice de hidrometração, índice de tratamento de esgotos, volume de água tratada, volume de esgoto tratado, dentre outros. Quanto aos indicadores de gestão têm-se: índice de produtividade, economias atingidas por paralisação, duração média das paralisações, dentre outros. 
Em relação aos da CEF:

Os indicadores da CEF foram elaborados em decorrência do Programa de Fomento à Parceria Público-Privada na Prestação de Serviços de Abastecimento de Água e de Esgotamento Sanitário, convênio entre a Caixa Econômica Federal e o Banco Nacional de Desenvolvimento Econômico e Social. Estes indicadores avaliam se os serviços atendem aos requisitos contidos na Lei de Concessões 8.987, de 1995. Esses indicadores estão divididos em duas categorias, a saber: indicadores técnicos e indicadores gerenciais (CEF s.d.p).

Os indicadores técnicos para o sistema de abastecimento de água são: qualidade de água distribuída; cobertura do sistema de abastecimento de água; regularidade do abastecimento de água e índice de perdas no sistema de distribuição. Já os indicadores técnicos para o sistema de esgotos sanitários são: cobertura do sistema de esgotos sanitários; eficiência do sistema de coleta de esgotos sanitários e índice de tratamento de esgotos.

Em relação aos indicadores estabelecidos como gerenciais, têm-se: índice de eficiência na prestação de serviços e no atendimento ao público; índice de adequação do sistema de comercialização dos serviços e indicador do nível de cortesia e de qualidade percebida pelos usuários na prestação dos serviços.

Em relação aos indicadores do PNQS:

O Prêmio Nacional de Qualidade em Saneamento - PNQS. "é um instrumento de referência na avaliação da gestão de serviços de saneamento ambiental, nas organizações sediadas no Brasil. Tem como missão estimular a prática de modelos gerenciais compatíveis com melhores exemplos mundiais, através da promoção e do reconhecimento dos casos de sucesso que auxiliem no aprimoramento de setor de saneamento ambiental e no aumento da qualidade de vida da população". Para tanto, tem um rol de indicadores que avaliam o desempenho dessas organizações. Foi uma iniciativa da Associação 
Brasileira de Engenharia Sanitária e Ambiental e instituído por meio do Comitê Nacional da Qualidade (PNQS 2001). Esses indicadores estão divididos em seis categorias, a saber: indicadores relativos aos clientes e mercado; indicadores financeiros; indicadores relativos às pessoas; indicadores relativos aos fornecedores e parceiros, indicadores relativos ao meio ambiente e indicadores relativos aos processo de apoio e organizacionais.

Em relação ao ISA:

O "Indicador de Salubridade Ambiental - ISA abrange a caracterização qualitativa e quantitativa dos serviços de abastecimento de água, esgotos sanitários e limpeza pública, drenagem, controle de vetores, situação dos mananciais e um indicador sócio-econômico dos municípios e visa balizar ações compatíveis com as realidades regionais e locais". Foi elaborado para avaliar a eficácia do Plano Estadual de Saneamento de São Paulo (SÃO PAULO 1999). O ISA a ser obtido para todos os municípios do Estado de São Paulo é calculado pela média ponderada de indicadores específicos, a saber: indicador de abastecimento de água, indicador de esgotos sanitários, indicador de resíduos sólidos, indicador de controle de vetores, indicador de recursos hídricos e indicador sócio-econômico. Abrangem diferentes variáveis e subindicadores. A cada um deles correspondem o símbolo respectivo e a razão ou finalidade de sua utilização.

De posse desse levantamento, foram escolhidos alguns dos indicadores do SNIS para cada município estudado, pois é o único que traz os indicadores já calculados em forma de banco de dados e que cobriram algumas lacunas existentes em relação às informações enviadas pelos gestores através dos questionários, conforme pode ser observado nas tabelas 12, 18, 25 e 29 do item 4 Resultados da Pesquisa. Os indicadores da CEF, do ISA e do PNQS teriam que ser calculados esbarrando da mesma forma na ausência de dados para gerá-los; além do mais, isso não fazia parte do escopo da tese. Em relação aos indicadores da CEF, ressalta-se que esses são utilizados para verificar se a concessionária atende aos requisitos estabelecidos na lei de 
concessões, sendo bastante direcionado para a questão da concessão, mas não sendo também objetivo da tese, eles foram descartados.

Após conhecimento adquirido pela pesquisa bibliográfica, documental, resultados depreendidos dos questionários, bem como daqueles observados nas políticas públicas e nas políticas de governo, pode-se finalmente partir para a fase de investigação explicativa para analisar eficiência e eficácia da gestão municipal e estadual dos serviços de água e esgoto.

\subsection{Investigação explicativa}

A "Investigação explicativa é aquela cujo principal objetivo é tornar inteligível, é justificar os motivos de alguma coisa. Visa, portanto, esclarecer quais fatores contribuem, de alguma forma, para a ocorrência de determinado fenômeno. Pressupõe pesquisa descritiva, como base para suas explicações" (VERGARA 1990). Então, para essa investigação, foram adotados indicadores que possibilitaram mostrar eficiência e eficácia da gestão dos serviços de água e esgoto, em cada um dos quatro municípios, como cobertura de água e esgoto, investimentos nos sistemas de água e esgoto, índices de esgoto tratado, programas, projetos, metas e diretrizes voltadas para saneamento básico.

Por outro lado, para o desenvolvimento das interpretações, comparações, análises e discussões das principais questões levantadas e abordadas em relação às esferas de governo estadual e municipal, referentes à gestão dos serviços de água e esgoto, foi necessário compreender fatos escondidos por trás das aparências, como aqueles ligados às políticas de governo, muitas vezes envolvendo questões político-partidárias, pois, conforme diz KOCHE (1999), é necessário compreender a cadeia de relações que se esconde por trás das aparências sensíveis dos fatos.

Assim sendo, percebe-se que as análises necessárias à demonstração da hipótese inicialmente colocada caracterizaram-se como qualitativa e quantitativa. 
Diante dessas ferramentas, explanadas até o momento, é que aponta-se a seguir, a forma de análise dos resultados da pesquisa.

\subsection{Forma de Análise dos Resultados da Pesquisa}

Construída a lógica da pesquisa e definidos os parâmetros qualitativos e quantitativos para a análise dos resultados, buscou-se fazer os cruzamentos desses parâmetros que permitiram analisar diferenças na eficiência e na eficácia da gestão sob responsabilidade municipal e estadual dos serviços de água e esgoto. Os parâmetros são aqueles citados nos itens 3.2, 3.3 e 3.4. Para adentrar a discussão da forma de análise desses parâmetros, é importante ressaltar aqui os conceitos definidos para a eficiência e eficácia na gestão.

Portanto para os efeitos deste trabalho, eficiência na gestão dos serviços de água e esgoto se dá quando o responsável por esses serviços e(ou) os governantes dos municípios estabelecem programas, projetos, obras e atividades para que recursos sejam aplicados, no sentido de levar água de boa qualidade e em quantidade suficiente à população, e coletar e tratar os efluentes, minimizando a poluição dos recursos hídricos. Desse modo definiuse como parâmetros para medir a eficiência as diretrizes destacadas nos artigos das leis municipais cruzando - as com programas, projetos, atividades, obras e metas destacados nos Planos Plurianuais, Leis de Diretrizes Orçamentárias, Leis Orçamentárias Anuais, Orçamentos Anuais e Planejamentos Estratégicos.

Observa-se, assim, que a análise realiza-se comparando políticas públicas com políticas de governo, identificando o que foi declarado em leis e o que foi praticado pelos governantes das prefeituras e dos gestores dos serviços de água e esgoto e resultados alcançados.

Já a eficácia na gestão dos serviços de água e esgoto se dá quando se tem resultados sociais, ou seja, quando a população usufrui da água e dos serviços de esgoto, como nítida conseqüência de abrangência dos serviços, 
incluindo cada vez mais, maior número de habitantes, tanto em termos de cobertura de água, como coleta e tratamento de esgoto. Assim, definiu-se como parâmetros para medir eficácia, as informações originadas dos questionários e da pesquisa documental como: evolução da população atendida por coleta de esgoto em função da evolução da população urbana do município; evolução do volume de esgoto coletado em função da evolução do volume de esgoto tratado; evolução do investimento em sistema de esgoto em função da evolução da população urbana; evolução do número de economias de esgoto em função da evolução da população urbana; evolução da população atendida por água em função da evolução da população do município; evolução do número de economias ativas de água em função da evolução da população; e evolução do volume de água faturado em função da evolução da população urbana, cruzando-os com diretrizes destacadas nos artigos das leis orgânicas e dos planos diretores com programas, projetos, atividades obras e metas estabelecidas nos Planos Plurianuais, Leis de Diretrizes Orçamentárias, Leis Orçamentárias Anuais, Orçamentos Anuais e Planejamentos Estratégicos.

Finalmente as diretrizes destacadas das leis federal e estadual foram tomadas como parâmetros norteadores para a identificação das políticas públicas municipais e estadual.

Essa forma de análise dos resultados da pesquisa permitiu discutir as diferenças na eficiência e na eficácia dos serviços de água e esgoto em relação às esferas de governo estadual ou municipal e também quanto às políticas públicas e políticas de governo. E, diante dos procedimentos metodológicos ora descritos, apresentam-se, no item 4, os resultados alcançados por essa pesquisa. 


\section{Resultados da Pesquisa}

Tudo que você tem não é seu, tudo que você guardar pertence ao tempo que tudo transformará (Lampirônicos).

Os resultados apresentados neste item retratam os métodos anteriormente descritos e adotados para o desenvolvimento dessa tese, quais sejam, pesquisa bibliográfica, documental, explicativa e aplicação dos questionários. Merecem ser destacadas algumas limitações encontradas para os métodos de pesquisa documental e aplicação dos questionários.

Quanto à limitação do método de pesquisa documental em relação aos órgãos gestores dos serviços de água e esgoto e em relação aos gestores dos municípios destaca-se que :

> Os documentos como o Planejamento Estratégico dos órgãos gestores dos serviços de água e esgoto de Campinas e Santo André, para o período da pesquisa, 1996-2000, não foram arquivados de forma completa, ou seja, não havia memória suficiente sobre eles, impossibilitando as devidas consultas. Esse documento possibilitaria o conhecimento de importantes resultados operacionais, técnicos e gerenciais numa série histórica pertinente à pesquisa. Em relação aos resultados desse planejamento para o órgão gestor desses serviços, foram encontrados apenas o do ano de 1996. Já para Santo André, nenhum resultado foi encontrado. Quanto aos Municípios de São José dos Campos e Santos, o planejamento estratégico não foi disponibilizado de forma desagregada por município e, sim, para a Companhia como um todo, dificultando a análise dos resultados de forma individualizada nesses municípios.

Os documentos de base histórica - estruturação da gestão dos serviços de água e esgoto - nos Municípios de Santos e São José dos Campos não foram encontradas no órgão gestor desses serviços.

> Os Planos Plurianuais, Leis de Diretrizes Orçamentárias e Orçamentos da prefeitura, como no caso de Santo André, não estavam arquivados na 
respectiva Secretaria que cuida do orçamento, tendo-se recorrido à Câmara Municipal da cidade.

> Em relação ao Plano Plurianual de Investimentos dos órgãos gestores dos serviços de água e esgoto dos municípios de São José dos Campos e Santos, estes não foram disponibilizados para consulta, o que dificultou sensivelmente o trabalho.

Pôde ser observado durante a pesquisa documental que grande parte do material que é produzido pelos órgãos gestores dos municípios, como dos órgãos gestores dos serviços de água e esgoto, não são publicados e disponibilizados ao público, dificultando um conhecimento mais apurado dos programas que são desenvolvidos nos municípios.

Em relação às limitações do método de aplicação de questionários, destacam-se:

Dificuldade de retorno das respostas em tempo hábil, de forma a compatibilizá-las com o cronograma da tese. O tempo de respostas variou de 5 a 2 meses, mesmo a pesquisadora insistindo de forma sistemática. O período mais longo dessas respostas foi o do órgão gestor estadual dos serviços de água e esgoto. Esse tempo de demora relativo aos 4 municípios pode ser atribuído ao fato de a série histórica da pesquisa ser longa, abrangendo 5 anos de coleta de dados, e de que nem todos os órgãos gestores daqueles municípios possuem sistemas de informações digitais, de modo a permitir agilidade na disposição; por outro lado, à limitação de funcionários para responder essa demanda; à falta de articulação entre Universidade, governos municipais e estaduais que permitam retroalimentar o sistema; ou, ainda, a questões puramente políticas, ou à falta nas instituições da cultura de tornar públicas as informações.

> Nem todos os órgãos gestores responderam os questionários de forma satisfatória, indo desde perguntas não respondidas até perguntas respondidas somente para um ano, sendo que o período de pesquisa abrange 5 anos (1996 a 2000). 
Isto posto, e salientando que a gestão enquanto ato de gerir e administrar precisa integrar tanto as políticas públicas quanto as políticas de governo, como a eficiência e eficácia programadas, é que apresentam-se neste item os resultados obtidos na pesquisa para a análise da gestão dos serviços de água e esgoto nos Municípios de Campinas, Santo André, São José dos Campos e Santos. Para tanto, buscou-se identificar políticas públicas relacionadas ao saneamento básico - água e esgoto - nos âmbitos nacional, estadual (São Paulo) e municipal dessas cidades. Buscou-se também identificar as políticas de governo em cada um desses municípios, o que demandou ainda caracterizar cada um deles com dados como localização geográfica, população e estruturação da gestão dos serviços de água e esgoto.

\subsection{Políticas públicas}

Assim, nessa seqüência, é que apresentam-se as políticas públicas relacionadas ao saneamento básico - água e esgoto - e aquelas com estreita ligação com os serviços de água e esgoto, contemplando legislações federal, estadual e municipal, conforme segue.

Para o estudo da legislação de âmbito nacional, foram selecionadas a: Constituição Federal de 1988, a Política Nacional de Meio Ambiente, instituída pela Lei 6.938, de 31/08/1981, a Política Nacional de Saúde, instituída pela Lei 8.080, de 19/09/1990, e a Política Nacional de Recursos Hídricos, instituída pela Lei 9.433 , de 08/01/1997. Foram identificadas nos artigos dessas leis, diretrizes relacionadas ao saneamento básico -água e esgoto - e também aquelas direcionadas às responsabilidades dos estados e municípios, no sentido de estarem promovendo sua autonomia em relação ao saneamento básico.

Em relação ao âmbito Estadual (São Paulo), as leis selecionadas foram: Constituição do Estado de 1989, Política Estadual de Saneamento, instituída pela Lei 7.750, de 31/03/1992, e Política de Recursos Hídricos, instituída pela Lei 7.663, de 30/12/1991. Da mesma forma que as nacionais, foram identificadas nos artigos dessas leis, diretrizes relacionadas ao saneamento 
básico -água e esgoto - e também aquelas direcionadas às responsabilidades afetas ao Estado de São Paulo e aos municípios paulistas.

Já quanto à legislação de âmbito Municipal, selecionaram-se: Leis Orgânicas e Planos Diretores dos 4 municípios.

As diretrizes destacadas nas leis em relação à responsabilidade municipal, estadual e federal apresentam-se da seguinte forma:

Letra normal $=$ entendida como de aspectos nacionais

Letra em negrito $=$ entendida como de responsabilidade do estado.

Letra em itálico = entendida como de responsabilidade do município.

Letra em itálico e em negrito = entendida como de responsabilidade tanto do estado quanto do município.

Posto isto, tem-se a exposição dos artigos das legislações para os três níveis de governo julgados pertinentes como parâmetros para a análise das políticas públicas no contexto dessa pesquisa.

A) Com relação à legislação de âmbito nacional:

A1) Diretrizes da Constituição Federal de 1988 (BRASIL 1999):

O município deve ser regido pela Lei Orgânica (art.29).

Compete aos municípios legislar sobre assuntos de interesse local; organizar e prestar, diretamente ou sob regime de concessão ou permissão, os serviços públicos de interesse local. (art. 30, inciso V).

Leis de iniciativa do Poder Executivo estabelecerão: 0 plano plurianual; as diretrizes orçamentárias e os orçamentos anuais (art.165, incisos de I a III).

O plano diretor, aprovado pela Câmara Municipal, é obrigatório para cidades com mais de vinte mil habitantes; é o instrumento básico da política de desenvolvimento e de expansão urbana (art. 182, parágrafo 1). 
Ao sistema único de saúde compete participar da formulação da política e da execução das ações de saneamento básico e colaborar na proteção do meio ambiente (art. 200, inciso IV, e VIII).

Todos têm direito ao meio ambiente ecologicamente equilibrado, bem de uso comum do povo e essencial à sadia qualidade de vida, impondo-se ao Poder Público e à coletividade o dever de defendê-lo e preservá-lo para as presentes e futuras gerações (art. 225).

A2) Política Nacional de Meio Ambiente de 1981 (BRASIL 2000) - em relação às diretrizes voltadas ao saneamento básico, os destaques são:

A Política Nacional do Meio Ambiente, visará à compatibilização do desenvolvimento econômico-social com a preservação da qualidade do meio ambiente e do equilíbrio ecológico; à definição de áreas prioritárias de ação governamental relativa à qualidade e ao equilíbrio ecológico, atendendo aos interesses da União, dos Estados, do Distrito Federal, dos Territórios e dos Municípios (art.4 incisos I e II).

As diretrizes da Política Nacional do Meio Ambiente serão formuladas em normas e planos, destinados a orientar a ação dos governos da União, dos Estados, do Distrito Federal, dos Territórios e dos Municípios no que se relaciona com a preservação da qualidade ambiental e manutenção do equilíbrio ecológico (art. 5).

A3) Política Nacional de Saúde de 1990 (BRASIL 2002), - em relação às diretrizes voltadas ao saneamento básico, têm-se:

Estão incluídas no campo de atuação do Sistema Único de Saúde (SUS) a participação na formulação da política e na execução de ações de saneamento básico (art. 6, inciso II).

A articulação das políticas e programas a cargo das comissões intersetoriais, abrangerá: saneamento e meio ambiente (art. 13, inciso II). 
A União, os Estados, o Distrito Federal e os Municípios exercerão, em seu âmbito administrativo: a participação de formulação da política e da execução das ações de saneamento básico e colaborarão na proteção e recuperação do meio ambiente e proporão a celebração de convênios, acordos e protocolos internacionais relativos à saúde, saneamento e meio ambiente (art. 15, incisos VII e XV).

À direção nacional do Sistema Único da Saúde (SUS) compete participar na formulação e na implementação das políticas de saneamento básico e participar da definição de normas e mecanismos de controle, com órgãos afins, de agravo sobre o meio ambiente ou dele decorrentes, que tenham repercussão na saúde humana (art.16, inciso II e IV).

À direção estadual do Sistema Único de Saúde (SUS) compete participar, junto com os órgãos afins, do controle dos agravos do meio ambiente que tenham repercussão na saúde humana e participar da formulação da política e da execução de ações de saneamento básico (art.17, incisos V e VI).

À direção municipal do Sistema de Saúde (SUS) compete executar serviços de saneamento básico e colaborar na fiscalização das agressões ao meio ambiente que tenham repercussão sobre a saúde humana e atuar, junto aos órgãos municipais, estaduais e federais competentes, para controlá-las. (art. 18, incisos $(V$ e $V I)$.

As ações de saneamento que venham a ser executadas supletivamente pelo Sistema Único de Saúde (SUS) serão financiadas por recursos tarifários específicos e outros da União, Estados, Distrito Federal, Municípios e, em particular, do Sistema Financeiro da Habitação (SFH) (art. 32, parágrafo 3).

A saúde é direito de todos e dever do Estado, garantido mediante políticas sociais e econômicas que visem à redução do risco de doença e de outros agravos e ao acesso universal e igualitário às ações e serviços para sua promoção, proteção e recuperação ( art.196). 
A4) Política Nacional de Recursos Hídricos de 1997 (BRASIL 2000) - em relação às diretrizes voltadas ao saneamento básico, têm-se:

São objetivos da política nacional de recursos hídricos assegurar à atual e às futuras gerações a necessária disponibilidade de água, em padrões de qualidade adequados aos respectivos usos (art. 2).

A gestão sistemática dos recursos hídricos, sem dissociação dos aspectos de quantidade e qualidade, e a integração da gestão de recursos hídricos com a gestão ambiental constituem diretrizes para a implementação da política nacional de recursos hídricos (art. 3, incisos I e III).

Os planos de recursos hídricos são instrumentos da política nacional de recursos hídricos (art. 5, inciso I).

Os planos de recursos hídricos são planos diretores que visam fundamentar e orientar a implementação da política nacional de recursos hídricos e o gerenciamento dos recursos hídricos (art.6).

Os planos de recursos hídricos serão elaborados por bacia hidrográfica, por Estado e para o país (art. 8).

B) Com relação à legislação do Estado de São Paulo:

B1) Constituição Paulista de 1989 (SÃO PAULO 2001) - têm-se as seguintes diretrizes:

O território estadual poderá ser dividido, total ou parcialmente, em unidades regionais constituídas por agrupamento de Municípios limítrofes, mediante lei complementar, para integrar a organização, 0 planejamento e a execução de funções públicas de interesse comum, atendidas as respectivas peculiaridades.(art.153).

Os Municípios deverão compatibilizar, no que couber, seus planos, programas, orçamentos, investimentos e ações às metas, diretrizes e objetivos estabelecidos nos planos e programas estaduais, regionais e 
setoriais de desenvolvimento econômico-social e de ordenação territorial, quando expressamente estabelecidos pelo conselho a que se refere o art. 154, que estabelece que o Estado criará, mediante lei complementar, para cada unidade regional, um conselho de caráter normativo e deliberativo, bem como disporá a organização, a articulação, a coordenação e, conforme o caso, a fusão de entidades ou órgãos públicos atuantes na região, assegurada, nestes e naquele, a participação paritária do conjunto dos municípios, com relação ao Estado.

O Estado, no que couber, compatibilizará os planos e programas estaduais, regionais e setoriais de desenvolvimento, com o plano diretor dos Municípios e as prioridades da população local (parágrafo único, art. 155).

Os planos plurianuais do Estado estabelecerão, de forma regionalizada, as diretrizes, objetivos e metas da Administração Estadual (art. 156).

O Estado e os Municípios destinarão recursos financeiros específicos, nos respectivos planos plurianuais e orçamentos, para 0 desenvolvimento de funções públicas de interesse comum, observado o disposto no art. 174 desta Constituição (art. 157).

Incumbe ao Estado e aos Municípios promover programas de construção de moradias populares, de melhoria das condições habitacionais e de saneamento básico (art.182).

Ao Estado, em consonância com seus objetivos de desenvolvimento econômico e social, cabe estabelecer, mediante lei, diretrizes para localização e integração das atividades industriais, considerando os aspectos ambientais, locacionais, sociais, econômicos e estratégicos, e atendendo ao melhor aproveitamento das condições naturais urbanas e de organização especial (art. 183).

- Estado e os Municípios providenciarão, com a participação da coletividade, a preservação, conservação, defesa, recuperação e melhoria 
do meio ambiente natural, artificial e do trabalho, atendidas as peculiaridades regionais e locais e em harmonia com o desenvolvimento social e econômico (art. 191).

- Estado apoiará a formação de consórcios entre os Municípios, objetivando a solução de problemas comuns relativos à proteção ambiental, em particular à preservação dos recursos hídricos e ao uso equilibrado dos recursos naturais (art. 201).

O Estado instituirá, por lei, sistema integrado de gerenciamento dos recursos hídricos, congregando órgãos estaduais e municipais e a sociedade civil, e assegurará meios financeiros e institucionais, para: a utilização racional das águas superficiais e subterrâneas e sua prioridade para abastecimento às populações; o aproveitamento múltiplo dos recursos hídricos e o rateio dos custos das respectivas obras, na forma da lei; a proteção das águas contra ações que possam comprometer o seu uso atual e futuro; a defesa contra eventos críticos, que ofereçam riscos à saúde e segurança públicas e prejuízos econômicos ou sociais; a celebração de convênios com os Municípios, para a gestão, por estes, das águas de interesse exclusivamente local; a gestão descentralizada, participativa e integrada em relação aos demais recursos naturais e às peculiaridades da respectiva bacia hidrográfica (art. 205, incisos de I a VI).

O Poder Público, mediante mecanismos próprios, definidos em lei, contribuirá para o desenvolvimento dos Municípios em cujos territórios se localizarem reservatórios hídricos e naqueles que recebam o impacto deles (art. 207).

A lei estabelecerá a política das ações e obras de saneamento básico no Estado, respeitando os seguintes princípios: criação e desenvolvimento de mecanismos institucionais e financeiros, destinados a assegurar os benefícios do saneamento à totalidade da população; prestação de assistência técnica e financeira aos Municípios, para o desenvolvimento dos seus serviços; orientação técnica para os programas visando ao 
tratamento de despejos urbanos e industriais e de resíduos sólidos, e fomento à implantação de soluções comuns, mediante planos regionais de ação integrada (art. 215, incisos de I a III).

O Estado instituirá, por lei, plano plurianual de saneamento estabelecendo as diretrizes e os programas para as ações nesse campo; o plano, objeto deste artigo, deverá respeitar as peculiaridades regionais e locais e as características das bacias hidrográficas e dos respectivos recursos hídricos. O Estado assegurará condições para a correta operação, necessária ampliação e eficiente administração dos serviços de saneamento básico prestados por concessionária sob seu controle acionário. As ações de saneamento deverão prever a utilização racional da água, do solo e do ar, de modo compatível com a preservação e melhoria da qualidade da saúde pública e do meio ambiente e com a eficiência dos serviços públicos de saneamento (art. 216 parágrafos 1 a $3)$.

Compete ao Sistema Único de Saúde, nos termos da lei; a participação na formulação da política e na execução das ações de saneamento básico e a revisão do Código Sanitário Estadual a cada cinco anos (art. 223, incisos IV $\mathrm{XI}$ ).

B2) Política Estadual de Saneamento de 1992 (SÃO PAULO 1992) - têm-se as seguintes diretrizes:

A política estadual de saneamento tem por finalidade disciplinar 0 planejamento e a execução das ações, obras e serviços de saneamento no Estado de São Paulo, respeitada a autonomia dos municípios (art.1).

As ações decorrentes da Política Estadual de Saneamento serão executadas por meio dos seguintes instrumentos:

Plano Estadual de Saneamento, definido como "o conjunto de elementos de informação, diagnóstico, definição de objetivos, metas e instrumentos, programas, execução, avaliação e controle que consubstanciam, organizam e integram o planejamento e a execução das ações de 
saneamento no Estado de São Paulo". Sistema Estadual de Saneamento SESAN, definido como "o conjunto de agentes institucionais que, no âmbito das respectivas competências, atribuições, prerrogativas e funções, interagem de modo articulado, integrado e cooperativo para a formulação, execução e atualização do Plano Estadual de Saneamento de acordo com os conceitos, os princípios, os objetivos, as diretrizes e os instrumentos da Política Estadual de Saneamento". Fundo Estadual de Saneamento - FESAN, caracterizado como " o instrumento institucional de caráter financeiro, destinado a reunir e canalizar recursos financeiros para a execução dos programas do Plano Estadual de Saneamento". (art. 3, incisos de I a III)

O Plano Estadual de Saneamento deve ser elaborado com base em Planos Regionais de Saneamento Ambiental, deve ser quadrienal e encaminhado à Assembléia Legislativa até 30 de junho do primeiro ano de mandato do Governador, do qual deverão constar, obrigatoriamente, a revisão, atualização e consolidação do Plano anteriormente vigente (art. 8).

As necessidades financeiras para elaboração, implantação e revisão do Plano Estadual de Saneamento deverão constar das leis sobre o plano plurianual, diretrizes orçamentárias e orçamento anual do Estado (parágrafo 1, art. 8).

Plano Estadual de Saneamento deverá ser elaborado de forma articulada com o Plano Estadual de Recursos Hídricos e com as políticas estaduais de saúde pública e de meio ambiente (parágrafo 2, art. 8).

Para avaliação da eficácia do Plano Estadual de Saneamento, o Conselho Estadual de Saneamento - CONESAN fará publicar, até 30 de abril de cada ano, os relatórios sobre a "Situação da Salubridade Ambiental na Região", de cada região ou sub-região em que o Estado será dividido, objetivando dar transparência à administração pública e subsídios às 
ações dos Poderes Executivos e Legislativo de âmbito municipal, estadual e federal (art. 9).

O Plano Estadual de Saneamento incluirá, entre outros, um programa permanente destinado a promover o desenvolvimento institucional dos serviços públicos de saneamento, para o alcance de níveis crescentes de desenvolvimento técnico, gerencial, econômico e financeiro e melhor aproveitamento das instalações existentes (parágrafo 1, art.10).

Nas regiões metropolitanas, aglomerações urbanas e microrregiões, definidas na forma do artigo 153 da Constituição Estadual, os planos deverão considerar o desenvolvimento, a organização e a execução de ações, serviços e obras de interesse comum para o saneamento ambiental, respeitada a autonomia municipal ( parágrafo 2, art.10).

Sistema Estadual de Saneamento é composto, direta ou indiretamente, entre outros, dos seguintes agentes: Os usuários dos serviços públicos de saneamento; As concessionárias, as permissionárias e os órgãos municipais e estaduais prestadores de serviços públicos de saneamento; As Secretarias Estaduais e Municipais envolvidas direta ou indiretamente no saneamento e na saúde pública do Estado e dos Municípios; As entidades de pesquisa, ensino e desenvolvimento tecnológico e gerencial do saneamento; Os órgãos gestores dos recursos hídricos e demais recursos ambientais pertinentes ao campo de atuação do saneamento; Os órgãos responsáveis pelo planejamento estratégico e pela gestão financeira do Estado; As empresas consultoras, construtoras, fabricantes, fornecedoras de materiais, equipamentos e serviços de saneamento e outras organizações não governamentais; os órgãos responsáveis pela Saúde Pública do Estado; as associações profissionais que militam no saneamento e outras organizações não governamentais; os órgãos estaduais responsáveis pela promoção do desenvolvimento dos municípios; os consórcios intermunicipais por bacias hidrográficas (art. 11, incisos de I a XI). 
O SESAN, como instrumento catalizador, articulador e integrador dos agentes institucionais, referidos no artigo 11, para a realização da Política Estadual de Saneamento, será concebido, estruturado e operacionalizado, com base nas seguintes premissas: os serviços públicos de saneamento de âmbito municipal serão prestados pelo Poder Executivo Municipal, diretamente ou sob regime de concessão ou permissão; os serviços públicos de saneamento de âmbito regional serão geridos mediante articulação e integração intermunicipal ou entre 0 Estado e os municípios; a conformação do SESAN se ampara no preceito constitucional que obriga o Estado a desenvolver mecanismos institucionais e financeiros que assegurem os benefícios do saneamento à totalidade da população (art.12, incisos de I a III ).

A conjugação das premissas estabelecidas nos incisos I a III deste artigo far-se-à por meio da formulação e implantação de mecanismos de articulação e integração entre o Estado e os Municípios, para que os respectivos compromissos constitucionais possam ser cumpridos harmonicamente em benefício da população.

Qualquer que seja a modalidade de prestação do serviço público de saneamento, a entidade responsável obrigar-se-à ao cumprimento da legislação sanitária e ambiental em vigor, que determina os níveis de desempenho técnico e gerencial que nortearão o processo de articulação e integração entre o município e o Estado, na promoção da saúde da população, por meio do saneamento.

A atuação da União nas ações de saneamento no Estado será potencializada e racionalizada pela interação com o SESAN.

O órgão concessionário ou permissionário de serviços públicos de saneamento, nos termos do inciso I deste artigo, criará canais de interlocução com o Poder Executivo Municipal, ao qual será assegurada a participação e o acompanhamento das ações, serviços e obras de seu interesse (art. 12 parágrafos de 1 a 4). 
Para assegurar os benefícios do saneamento à totalidade da população, 0 SESAN deverá contar com mecanismos institucionais e financeiros que permitam a ação articulada e integrada entre o Estado e os Municípios, cabendo: ao Estado ou à entidade intermunicipal, na forma da lei estadual, a gestão das questões intermunicipais, visando racionalizar ações de interesse comum dos municípios; aos Municípios, o gerenciamento das instalações e serviços de saneamento essencialmente municipais, coordenando as ações pertinentes com os serviços e obras de expansão urbana horizontal e vertical, pavimentação, disposição de resíduos, drenagem de águas pluviais, uso e ocupação do solo e demais atividades de natureza tipicamente local. 0 Estado assegurará condições para a correta operação, necessária ampliação e eficiente administração dos serviços de saneamento básico prestados por concessionárias sob seu controle acionário (art. 14, incisos I e II e parágrafo único).

Ficam criados, como órgãos colegiados consultivos e deliberativos, de nível estratégico: Conselho Estadual de Saneamento - CONESAN, de nível central; comissões regionais de saneamento ambiental - CRESAN, de nível regional (art. 15, incisos I e II).

A área geográfica de atuação das Comissões Regionais de Saneamento Ambiental - CRESAN deverá ser delimitada com base na Unidade Hidrográfica estabelecida no âmbito do sistema integrado de gerenciamento de recursos hídricos e harmonizada com o Plano Estadual de Saneamento (art. 15, parágrafo único). No entanto, como o CONESAN foi instalado em 1997, após cinco anos decorridos da aprovação desta Lei n. 7750/1992 e, que nesse momento já existia o Sistema Estadual de Recursos Hídricos houve a integração das estruturas de âmbito regional dos Sistemas Estaduais de Saneamento com o de Recursos Hídricos. Essa integração fez com que as atribuições das Comissões Regionais de Saneamento (CRESANs), previstas pela Lei n. 7750/1992 fossem transferidas para os Comitês de Bacias Hidrográficas criando-se Câmaras Técnicas de Saneamento, no âmbito de cada Comitê de Bacia Hidrográfica (SÃO PAULO 2002). 
O Plano Estadual de Saneamento é o único instrumento hábil para orientar a aplicação dos recursos financeiros do Fundo Estadual de Saneamento - FESAN (art. 25, parágrafo único).

B3) Política de Recursos Hídricos de 1991 (SÃO PAULO 2002) - em relação às diretrizes identificadas para as políticas estaduais têm-se para a

O Estado instituirá por lei, com atualizações periódicas, o Plano Estadual de Recursos Hídricos - PERH tomando por base os planos de bacias hidrográficas, nas normas relativas à proteção do meio ambiente, as diretrizes do planejamento e gerenciamento ambientais e conterá, dentre outros, os seguintes elementos: objetivos e diretrizes gerais, em níveis estadual e inter-regional, definidos mediante processo de planejamento iterativo que considere outros planos, gerais, regionais e setoriais, devidamente compatibilizado com as propostas de recuperação, proteção e conservação dos recursos hídricos do Estado (art. 16, inciso l).

Os planos de bacias hidrográficas conterão, dentre outros, os seguintes elementos: I - diretrizes gerais, a nível regional, capazes de orientar os planos diretores municipais, notadamente nos setores de crescimento urbano, localização industrial, proteção dos mananciais, exploração mineral, irrigação e saneamento, segundo as necessidades de recuperação, proteção e conservação dos recursos hídricos das bacias hidrográficas correspondentes; II - metas de curto, médio e longo prazos para se atingir índices progressivos de recuperação, proteção e conservação dos recursos hídricos da bacia (art.17 - incisos I e II).

O Estado poderá delegar aos municípios, que se organizarem técnica e administrativamente, o gerenciamento de recursos hídricos de interesse exclusivamente local, compreendendo, dentre outros, os de bacias hidrográficas que se situem exclusivamente no território do município e os aquíferos subterrâneos situados em áreas urbanizadas (art. 32). 
O Plano Estadual de Recursos Hídricos será aprovado por lei cujo projeto será encaminhado à Assembléia Legislativa até o final do primeiro ano do mandato do Governador do Estado, com prazo de vigência de quatro anos (art. 18).

As diretrizes e necessidades financeiras para elaboração e implantação do Plano Estadual de Recursos Hídricos deverão constar das leis sobre o plano plurianual, diretrizes orçamentárias e orçamento anual do Estado (art. 18, parágrafo único).

C) Com relação à legislação de âmbito Municipal.

Findados os aspectos das políticas estaduais, buscou-se identificar as diretrizes mais relevantes das Leis Orgânicas e dos Planos Diretores dos Municípios de Campinas, Santo André, São José dos Campos e Santos, como segue:

C1) Município de Campinas

Em relação à Lei Orgânica de Campinas (CAMPINAS 2001), os seguintes aspectos foram destacados:

Compete ao Município, no exercício de sua autonomia, legislar sobre tudo quanto respeite ao interesse local tendo como objetivo o pleno desenvolvimento de suas funções sociais e garantir o bem estar de seus habitantes, cabendo-Ihe privativamente, entre outras, atribuições: elaborar o plano plurianual, as diretrizes orçamentarias e os orçamentos anuais; organizar e prestar os serviços públicos de forma centralizada ou descentralizada, sendo neste caso: a) prioritariamente, por outorga, às suas autarquias ou entidades paraestatais; b) por delegação, a particulares, mediante concessão, permissão ou autorização; participar e integrar, através de consórcio ou outra forma de organização, com outros municípios, para o estudo e a solução de problemas comuns (art. 4, incisos I, IV, XXII). 
Compete ao Município, concorrentemente com a União e o Estado, proteger o meio ambiente e combater a poluição em qualquer de suas formas (artigo 5, inciso VI).

O Município assegurará, anualmente, recursos necessários, para no prazo de 10 anos, a partir da promulgação desta lei, promover o tratamento de todo $o$ esgoto da cidade (art. 8, disposições transitórias).

Leis de iniciativa do Executivo estabelecerão, com observância dos preceitos correspondentes da Constituição Federal: o plano plurianual; as diretrizes orçamentárias; os orçamentos anuais (art. 166, incisos de I a III).

A lei que instituir o plano plurianual estabelecerá as diretrizes, objetivos e metas da Administração Pública para as despesas de capital e outras dela decorrentes e as relativas aos programas de duração continuada, em consonância com o Plano Diretor (art. 166, parágrafo 1).

A lei de diretrizes orçamentárias compreenderá as metas e prioridades da administração pública, incluindo as despesas de capital para o exercício financeiro subsequente, orientará a elaboração da lei orçamentária anual e disporá sobre as alterações na legislação tributária e estabelecerá a política de fomento (art. 166, parágrafo 2).

A lei orçamentária anual compreenderá: o orçamento de investimentos das empresas em que o Município, direta ou indiretamente, detenha a maioria do capital social com direito a voto (art. 166, parágrafo 3).

O Plano Diretor, aprovado pela Câmara Municipal, é o instrumento básico da política de desenvolvimento e expansão urbana e deverá considerar a totalidade do território municipal (art. 172).

São atribuições e finalidades do sistema de administração: elaborar um Plano Municipal de Meio Ambiente e Recursos Naturais; manifestar-se sobre a participação do Município no sistema integrado de gerenciamento de recursos 
hídricos previstos no artigo 205 da Constituição do Estado de São Paulo (art. 188, incisos ( e XVI).

O Município instituirá um plano municipal de saneamento em consonância com o Plano Diretor, visando a: assegurar os benefícios do saneamento à totalidade da população; estabelecer a política tarifária; ações de saneamento que deverão ser compatíveis com a proteção ambiental (art. 203, incisos de I a III).

A política tarifária definirá uma parcela específica, contabilizada em carteira própria destinada aos investimentos para o tratamento do esgoto (art. 203, parágrafo 2).

Subsídio ou redução de tarifa somente poderão ser concedidos mediante autorização legislativa (art. 203, parágrafo 3).

A saúde, entendida como a condição plena de bem estar bio-psico-social, é direito fundamental do ser humano e dever do Poder Público, assegurado através do desenvolvimento de: I - políticas sociais, econômicas e ambientais, que visem à eliminação do risco de doenças e de outros agravos à saúde; II acesso universal e igualitário de todos os munícipes às ações e serviços de promoção, proteção e recuperação da saúde, sem qualquer discriminação (art. 205, incisos ( e II).

A partir de 1991, a Lei de Diretrizes Orçamentárias, o Código Tributário, o Código de Obras, o Plano Plurianual e o Orçamento anual deverão subordinarse ao Plano Diretor do Município (art. 268).

Quanto às diretrizes voltadas ao saneamento básico identificadas no Plano Diretor de Campinas (PMC 1995), aprovado pela Lei Complementar de 17/01/1996, têm-se:

O Plano Diretor da cidade teve sua última revisão em 1996 e incorporou para a sua formulação o Plano Diretor de Água de 1993 e Plano Diretor de Esgotos de 1994 como "elementos importantes na definição das potencialidades e 
restrições à ocupação urbana das diferentes regiões do município" (CAMPINAS 1996).

As diretrizes básicas identificadas na formulação das políticas de infra-estrutura do setor de saneamento, especificamente as relacionadas com a gestão dos serviços de água esgoto, foram as seguintes:

Considerar a abrangência metropolitana na questão do abastecimento de água e de esgotamento sanitário;

Adotar uma política permanente de conservação da água de abastecimento;

Definir critérios de cobrança das despesas com a prestação dos serviços de esgotamento sanitário, produção e distribuição da água potável fluorada, mediante a imposição de tarifas e taxas diferenciadas, observados os aspectos técnicos, custos, a destinação social dos serviços e o poder aquisitivo da população beneficiada;

Priorizar obras de saneamento em áreas com maior concentração de população, notadamente nos bairros de baixa renda;

Não executar obras de saneamento nas áreas ocupadas consideradas de risco ou impróprias à ocupação urbana, salvo aquelas consideradas emergenciais e indispensáveis à segurança da população, até sua remoção do local;

Procurar alternativas tecnológicas de saneamento para áreas distantes da malha urbana e para áreas onde haja interesse em conter a ocupação urbana.

C2) Município de Santo André

Passando à identificação das diretrizes voltadas ao saneamento básico - água e esgoto - do Município de Santo André, em sua Lei Orgânica (SANTO ANDRÉ 2001), tem-se o seguinte:

Cabe ao Município, concorrentemente à ação do Estado e da União, conforme preceitos constitucionais, resguardar os direitos dos munícipes com respeito à 
qualidade de vida, fiscalizando e controlando as atividades que, de maneira direta ou indireta, alterem o meio ambiente (art. 190).

O Município, dentro de sua competência, administrará o saneamento básico, conforme o plano diretor, através da administração direta ou indireta, ou através de concessão às empresas públicas ou privadas, fiscalizando e cumprindo os interesses da coletividade no que diz respeito à qualidade de vida (art. 205).

O tratamento de água para consumo, o tratamento de esgoto, assim como o transporte intermunicipal, são assuntos a serem estudados é planejados em conjunto com os municípios limítrofes que exijam planejamento integrado e ação conjunta permanente (art. 206).

Em atendimento aos incisos II e III do Artigo 215 da Constituição Estadual, caracterizando a sua responsabilidade nas soluções do tratamento e destinação final dos despejos urbanos e industriais e de resíduos sólidos, competirá ao Município, em cooperação técnica e financeira com o Estado, estabelecer solução integrada mediante consórcio, resguardadas as suas peculiaridades (art. 207).

Fica proibido o lançamento de efluentes e esgotos urbanos e industriais, sem o devido tratamento, em qualquer corpo de água (art. 208).

Os serviços de abastecimento de água e esgotamento sanitário só poderão ser executados pela administração descentralizada, através de autarquias ou entidades paraestatais (art. 209).

O planejamento, controle e avaliação das ações de saneamento contarão com a participação dos usuários domiciliares, comerciais e industriais, de representantes dos trabalhadores, do Poder Legislativo e do sistema único de saúde, a nível municipal (art. 210).

Compete ao Município, com relação aos serviços públicos de saneamento básico: formular e implantar a política municipal de saneamento básico, bem 
como controlar, fiscalizar e avaliar seu cumprimento; participar da formulação da política estadual de saneamento básico; planejar, projetar, executar, operar e manter os serviços de abastecimento de água e esgotamento sanitário; estabelecer áreas de preservação das águas utilizáveis para o abastecimento da população, nos termos da Constituição Estadual; implantar sistemas de alerta e defesa civil para garantir a segurança e a saúde pública quando de eventos hidrológicos indesejáveis; instituir programas permanentes de racionalização do uso das águas destinadas ao abastecimento público e industrial e de irrigação, assim como de combate às inundações e à erosão; planejar, projetar, executar, operar e manter a limpeza dos logradouros públicos, remoção, tratamento e destinação do lixo domiciliar e de outros resíduos; regulamentar e fiscalizar a geração, acondicionamento, armazenamento, coleta, transporte, tratamento e destino final de resíduos de qualquer natureza; estabelecer formas de cooperação com os outros municípios da Região Metropolitana de São Paulo, com o Estado ou demais entidades de governo para o planejamento, execução e operação das ações relativas à produção de água potável, tratamento de esgotos sanitários, drenagem das águas pluviais e tratamento e destinação de resíduos sólidos, tendo em vista as características de função de interesse comum de que tais ações se revestem na Região Metropolitana (art. 212, incisos de I a IX)).

O abastecimento de água, coleta e disposição adequada de esgotos e resíduos sólidos, e drenagem das águas pluviais, deverão ser executados observandose, entre outros, os seguintes preceitos: prioridade para as ações que visem à proteção e promoção da saúde pública; no abastecimento de água, prioridade para o atendimento do consumo domiciliar, assegurando-se a todos os munícipes quantidade suficiente para a adequada higiene com qualidade compatível com os padrões de potabilidade; preservação do equilíbrio ecológico; melhor aproveitamento da estrutura físico-territorial das bacias hidrográficas e dos respectivos recursos hídricos e a promoção do uso racional da água, visando à sua conservação; incentivo ao desenvolvimento econômico; necessidade de planejamento das ações de saneamento básico de modo integrado ao planejamento do desenvolvimento municipal e das ações de 
saúde e de proteção ao meio ambiente; reaproveitamento de resíduos de qualquer natureza, visando à conservação dos recursos naturais e energéticos (art. 213, incisos de I a VII).

Os serviços de abastecimento de água e de coleta e disposição de esgotos sanitários, prestados aos usuários ou postos à sua disposição, de modo específico e divisível, serão remunerados mediante: taxa instituída em razão da utilização efetiva ou potencial da infra-estrutura e do serviço público necessários à sua prestação; tarifa cobrada pelos serviços, efetivamente prestados, a qual poderá ser diferenciada em função do consumo e da capacidade econômica do usuário, definidos em lei (art. 214, incisos de I e II).

O Município, em conjunto com os demais do Grande $A B C$, articular-se-á no prazo máximo de três meses para, junto ao Governo do Estado, solucionar de forma integrada o abastecimento de água na região que, sendo da sua responsabilidade, deverá promover a captação, adução, tratamento e armazenamento de água para atender, em volume suficiente e qualidade, à demanda da população local (art. 17, das disposições transitórias).

Ainda no Município de Santo André, com relação ao Plano Diretor aprovado pela Lei 7.333 , de $26 / 12 / 1995$, as seguintes diretrizes foram identificadas para o saneamento básico:

O Plano Diretor de Santo André tem um capítulo específico para o saneamento, englobando o conjunto dos sistemas de abastecimento de água, coleta de esgoto, drenagem, limpeza urbana e prevenção de zoonozes. Serão destacados aqui somente os artigos referentes aos sistemas de água e esgoto.

O Abastecimento de água da malha urbana do Município integrado ao Sistema Adutor Metropolitano terá diretrizes contemplando: o atendimento pleno da população através de sistema público, com prioridade à demanda de água residencial, e o atendimento da parcela do consumo aos usos essenciais relativos á saúde e higiene da população; a promoção do uso racional da água e o combate às perdas, desperdício e usos suntuários, utilizando para tanto 
instrumentos tarifários e educativos para a comunidade; a distribuição de água de modo regular e contínuo, dentro dos padrões de potabilidade; o estudo e distribuição de água bruta para empresas (art. 31, incisos de I a IV).

O poder executivo, através do órgão competente, definirá o Plano Municipal de Abastecimento de Água (PMAA) nos moldes do Plano Diretor, contendo diretrizes gerais que permitam o atendimento da evolução da demanda.

Em função da integração com o Sistema Adutor Metropolitano, o poder executivo, através do órgão competente, poderá contratar a Companhia Estadual de Saneamento para o fornecimento de água potável, estabelecendo as condições de quantidade, regularidade e qualidade.

O poder executivo, através do órgão competente, atuará em cooperação no planejamento e operação do Sistema Adutor Metropolitano.

Nas Áreas de Proteção Ambiental (APM), será dada prioridade ao abastecimento através de sistemas individuais, exceto nos locais onde, em função da ocupação consolidada, a solução coletiva seja a mais indicada, obedecidas as prescrições dos órgãos de proteção ambiental (art. 32).

Fica a cargo do poder executivo adotar medidas para: manter o manancial do Parque do Pedroso como fonte de água para abastecimento público; manter em operação a Estação de Tratamento de Água do Guarará; viabilizar novas formas de captação, tratamento e distribuição de água (art. 33, incisos de I a III).

Na medida do decréscimo relativo de importância para o abastecimento do Município, em termos quantitativos, será realizado um processo de valorização do manancial e da ETA como instrumentos de educação ambiental e sanitária (art. 33, parágrafo único).

Haverá compatibilidade entre o Plano Municipal de Abastecimento de Água e a Lei de Uso e Ocupação do Solo (art. 34). 
A coleta e interceptação dos esgotos sanitários e industriais nas áreas pertencentes à Bacia do Alto Tamanduateí terão diretrizes contemplando: a melhoria e a otimização da coleta de esgotos, através da rede pública separadora absoluta, em consonância com o Plano Municipal de Drenagem; o condicionamento prévio ao lançamento, na rede pública, dos despejos provenientes de atividades industriais e comerciais que tenham características prejudiciais ao sistema de coleta, destinação e tratamento, compatibilizando o escoamento individualizado de águas pluviais; os efluentes hospitalares e afins deverão ser previamente compatibilizados para despejo na rede pública; o encaminhamento para a Estação de Tratamento de Esgotos no $A B C$ dos esgotos gerados na Bacia do Alto Tamanduateí, ou para ela exportados, conforme previsto no Plano Diretor de esgotos da Região Metropolitana de São Paulo; os coletores - tronco e as interligações necessárias ao encaminhamento dos esgotos à ETE ABC projetados, construídos e operados em colaboração com a Companhia Estadual responsável pelo tratamento dos esgotos na Região Metropolitana de São Paulo, conforme convênio firmado pela mesma; o projeto e a implantação de coletores-tronco serão executados em compatibilidade com os respectivos projetos e obras de drenagem e tratamento dos fundos de vale, para minimizar custos e maximizar benefícios ambientais, paisagísticos e sanitários nas sub-bacias correspondentes; o Município elaborará Plano Municipal de Esgotos Sanitários, com horizonte de 20 anos, compatibilizando com o Plano Municipal de Drenagem, nos moldes do Plano Diretor, prevendo faixas "non aedificandi" para escoamento de esgotos e águas pluviais em laterais e fundos de lotes (art. 35, incisos de I a V).

Na Zona de Expansão Urbana o Poder Executivo tratará da implantação de sistemas individuais de tratamento e disposição dos esgotos sanitários, utilizando-se da infiltração no solo, exceto nos locais onde, em função da ocupação consolidada, a solução coletiva com a reversão dos esgotos para a bacia do Tamanduateí seja a mais indicada (art.36).

Finalmente, para o Município de Santo André, foi encontrada a Política Municipal de Gestão e Saneamento Ambiental (SANTO ANDRÉ 1999), 
instituída pela Lei 7.733, de 14/10/1998. Assim sendo, nessa Política foram identificadas as diretrizes mais estreitamente ligadas aos serviços de água e esgoto, conforme segue:

Para o cumprimento do disposto no Artigo 30 da Constituição Federal, no que concerne ao Saneamento Ambiental, considera-se como de interesse local: a melhoria constante da qualidade do ar, da água, do solo, da paisagem e dos níveis de ruído e vibrações, mantendo-os dentro dos padrões técnicos estabelecidos pelas legislações de controle de poluição ambiental federal, estadual e municipal no que couber; a captação, o tratamento e a distribuição de água, assim como o monitoramento de sua qualidade; a coleta, a disposição e o tratamento de esgotos; o reaproveitamento de efluentes destinados a quaisquer atividades (art. 3, incisos VIII, X, XI, XII).

Ao Município, cabe mobilizar e coordenar ações, recursos humanos, financeiros, materiais técnicos e científicos e a participação da população na execução dos objetivos e interesses estabelecidos nessa lei, devendo para tanto: elaborar e implementar programas, planos e projetos de saneamento básico e de conservação e proteção ao meio ambiente; regulamentar e fiscalizar os serviços de saneamento ambiental prestados diretamente pelo Município ou através de concessões; planejar, projetar, executar, operar e manter os serviços de abastecimento de água para quaisquer finalidades, esgotamento sanitário, drenagem de águas e coleta, transporte, tratamento e disposição final de resíduos sólidos domiciliares; elaborar e coordenar a implementação de programas de educação ambiental; editar normas e padrões de controle ambiental e de saneamento básico, buscando compatibilizar qualidade e salubridade ambientais e desenvolvimento econômico; exercer o controle da poluição ambiental nas suas diferentes formas; definir áreas prioritárias de ação governamental visando à melhoria da qualidade e salubridade ambientais; estabelecer diretrizes específicas para a proteção de recursos hídricos, através de planos de uso e ocupação de áreas de drenagem de bacias e sub-bacias hidrográficas; estabelecer formas de cooperação com outros municípios da Região Metropolitana de São Paulo, com o Estado ou 
demais entidades do governo para o planejamento, execução e operação de ações em saneamento ambiental de interesse comum a essas esferas (artigo 24, incisos III a XII).

A execução de medidas de saneamento básico residencial, comercial e industrial, essenciais à salubridade ambiental, constitui obrigação do Poder Público, da coletividade e do indivíduo, que para tanto, no uso da propriedade, no manejo dos meios de produção e no exercício de qualquer atividade, ficam obrigados ao cumprimento das determinações legais, regulamentares, recomendações e interdições ditadas pelas autoridades ambientais, sanitárias e outras competentes (art. 25).

Os esgotos sanitários deverão ser coletados, tratados e receber destinação adequada, de forma a evitar-se contaminação dos recursos naturais (art. 26).

Os volumes de água consumida, esgotos coletados e águas drenadas serão mensurados através de equipamentos próprios, tecnicamente aprovados pelo SEMASA, para efeito de controle e cobrança pelos serviços prestados (artigo 27).

Compete ao SEMASA o estabelecimento de normas, regras e padrões de uso e cobrança relativos à exploração comercial de água, oriunda de mananciais superficiais ou subterrâneos cujas origens estejam ou não nos limites do município, efetuada por quaisquer estabelecimentos e distribuídos por rede ou caminhões-pipa (artigo 31).

C3) Município de São José dos Campos

Finalizados os destaques das políticas de Santo André, passa-se para o Município de São José dos Campos. Primeiro, em relação à Lei Orgânica e posteriormente ao Plano Diretor. Desse modo, as diretrizes mais relevantes destacadas da Lei Orgânica do Município (SÃO JOSÉ DOS CAMPOS 2001) foram: 
Ao Município compete, concorrentemente com a União ou o Estado, ou supletivamente: proteger o meio ambiente e combater a poluição em qualquer de suas formas; preservar as florestas, a fauna , a flora e o solo; - registrar, acompanhar e fiscalizar as concessões de direitos de pesquisa e exploração de recursos hídricos e minerais; promover diretamente, em convênios ou em colaboração com a União, Estado e outras instituições, programas de construção de moradias e a melhoria das condições habitacionais e de saneamento básico ( art. 22, incisos V, VI, IX, X).

O Poder Público Municipal, em colaboração com o Estado, assumirá, com a participação da comunidade, através de suas entidades representativas, os seguintes cuidados: proteção, preservação e recuperação do meio ambiente, em suas mais variadas formas (art. 230, inciso I).

O Poder Público Municipal deverá dar adequado tratamento e destino final aos resíduos sólidos e aos efluentes dos esgotos de origem doméstica, exigindo o mesmo procedimento aos responsáveis pela produção de resíduos sólidos e efluentes industriais, diretamente ou por concessão (art.232).

No campo dos recursos hídricos cabe ao Município: proibir o lançamento de efluentes urbanos e industriais em qualquer corpo d'água, nos termos da Constituição Estadual e iniciar as ações previstas em suas Disposições Transitórias, isoladamente ou em conjunto com o Estado ou outros Municípios da bacia ou região hidrográfica (art.239, inciso II).

Direito à saúde implica nos seguintes direitos fundamentais: condições dignas de trabalho, saneamento, moradia, alimentação, educação, transporte e lazer ( art.272, inciso l).

É de competência do Município, exercida pela Secretaria Municipal de Saúde: planejar e executar as ações de controle do meio ambiente e de saneamento básico, no âmbito do Município, em articulação com os demais órgãos governamentais (art.277, XIV). 
Compete ao Sistema Único de Saúde: a participação na formulação da política e na execução das ações de saneamento básico (art.27, inciso III).

O Município poderá criar e organizar seus serviços autônomos de água e esgoto (art.353).

Quanto às diretrizes mais relevantes extraídas do Plano Diretor do Município (SÃO JOSÉ DOS CAMPOS 2001), aprovado pela Lei Complementar n. ${ }^{\circ}$ 121/1995, têm-se:

As diretrizes referentes ao saneamento básico estão contempladas no capitulo do Planejamento Territorial, na seção das diretrizes específicas do Meio Ambiente e na subseção dos programas e projetos.

A Política de Meio Ambiente Municipal respeitará as seguintes diretrizes: participar do planejamento da racionalização do uso do solo, subsolo, da água, do ar, cobertura vegetal e fauna: participação do planejamento e fiscalização do uso dos recursos naturais e ambientais; participação do monitoramento da qualidade ambiental (art. 38, incisos II, III e VII).

São programas e projetos prioritários da Política Municipal do Meio Ambiente: Programa de controle e tratamento de esgotos domésticos do Município; cadastramento das ligações clandestinas de esgoto; estudo sobre as alternativas de controle e tratamento de esgotos domésticos para o Município; elaboração de campanhas educativas sobre os cuidados com o saneamento básico; programa de controle da qualidade das águas (art. 39, incisos Ve VI).

A política de infra-estrutura do Município observará as seguintes diretrizes: instituir e regulamentar o Conselho Municipal de Saneamento Básico com o objetivo de fomentar uma política municipal de saneamento autônoma e peculiar às necessidades locais e regionais; Rever o contrato de concessão dos serviços com a SABESP, visando melhorar as condições de saneamento básico do Município (art. 40, incisos IV, V). 
O sistema institucional prevê Criação do Conselho Municipal de Saneamento Básico que deverá ser detalhado e encaminhado em propositura de legislação (art. 69).

C4) Município de Santos

No que tange à Lei Orgânica (SANTOS 2001), as diretrizes encontradas para o saneamento básico foram:

Compete ao município: legislar sobre assuntos de interesse local; elaborar e executar o plano diretor, como instrumento básico da política de desenvolvimento e de expansão urbana (art. 6, incisos I e XI).

O município consignará, anualmente, no orçamento, percentual para preservação e recuperação do meio ambiente (art. 156).

O município direcionará esforços para compatibilizar a sua linha de desenvolvimento aos princípios de metropolização estabelecidos no artigo 153 da Constituição Estadual, em busca de uma ação integrada com os demais municípios definidos na legislação estadual (art. 167).

Para vinculação ao processo e desenvolvimento integrado, o município destinará recursos específicos, nos respectivos planos plurianuais e orçamentos, para desempenho das funções públicas de interesse comum (art.169).

Dentro do princípio de integração desenvolvimentista, o município atuará no Conselho de caráter normativo e deliberativo a ser criado pelo Estado, mediante lei complementar, na forma do art. 154 inciso 10, da Constituição Estadual (art. 170).

O município participará do sistema integrado de gerenciamento dos recursos hídricos, através do qual se assegurará meios financeiros e institucionais para: a utilização racional das águas superficiais e subterrâneas e sua prioridade para abastecimento da população; aproveitamento múltiplo dos recursos 
hídricos e o rateio dos custos das respectivas obras, na forma da lei; a gestão das águas de interesse exclusivamente local (art. 172, incisos I, II e V).

As ações do saneamento executadas em consonância com o Estado, devem prever a utilização racional da água, do solo e do ar, de modo compatível com a preservação e melhoria da qualidade da saúde pública e do meio ambiente (art. 175).

A lei estabelecerá política de ações visando a impedir que loteamentos e conjuntos habitacionais sejam construídos e ocupados sem o funcionamento adequado das redes de água potável e dos sistemas coletores de esgotos, com seus respectivos tratamentos e drenagem (art.176).

Na seção que trata da Saúde em seu artigo 188 diz que compete ao município: a participação na formulação das ações de proteção ao meio ambiente e de saneamento básico no âmbito do município.

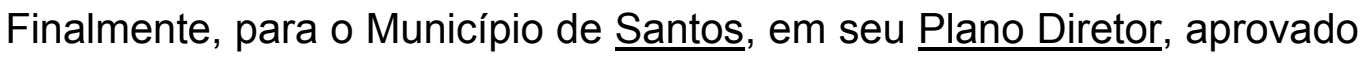
pela Lei Complementar n. ${ }^{\circ} 311$, de 23 de novembro de 1998, foram encontradas para o saneamento básico as seguintes diretrizes:

Promover a extensão da rede de saneamento básico nas áreas urbana e de expansão urbana (artigo 15).

Esse Plano Diretor é extremamente resumido, pois a reestruturação dos Planos Diretores do Município de Santos ocorre por meio de Leis Complementares, deixando de ser realizado nos moldes tradicionais de Plano substitutivo.

Como se vê, foram identificadas diretrizes das políticas públicas nacionais, estaduais e municipais voltadas ao saneamento básico, as quais foram comparadas com as políticas de governo estabelecidas para os 4 municípios no período de 1996-2000. Portanto, as políticas públicas e as políticas de governo foram tomadas como parâmetros de análise, conforme descrito anteriormente no item 3. Desse modo, para identificar as políticas de 
governo desse período, foram estudados os seguintes instrumentos: Plano Plurianual, Lei de Diretrizes Orçamentárias, Leis Orçamentárias Anuais, Orçamentos Anuais e Planejamentos Estratégicos.

\subsection{Políticas de governo}

Antes de adentrar as políticas de governo de cada município, coube situá-los dentro do contexto desta tese, destacando características como localização geográfica, população urbana, estruturação da gestão dos serviços, dentre outras. Inicia-se dessa forma, por ordem de grandeza de população, com os Municípios de Campinas e Santo André, cuja gestão dos serviços de água e esgoto se dá no âmbito do município.

\subsubsection{Campinas - gestão dos serviços de água e esgoto no âmbito do município}

Campinas conta com uma população de 968.172 habitantes, numa área de $796 \mathrm{Km}^{2}$, o que resulta numa densidade demográfica de aproximadamente 1.217 hab. $/ \mathrm{Km}^{2}$. Dessa população, 952.075 habitantes vivem em área urbana e 16.097 habitantes em área rural (IBGE 2002).

Observa-se na tabela 5 que a população vem crescendo significativamente e, segundo dados do SEADE (1999), a uma taxa geométrica de crescimento de 1,53\% a.a., durante o período 1991 - 2000. Nota-se ainda que a população rural vem diminuindo ao longo dos anos e que provavelmente está migrando para os grandes centros urbanos.

Tabela 5. Crescimento Populacional do Município de Campinas.

\begin{tabular}{|c|c|c|c|c|c|}
\hline Ano & $\mathbf{1 9 9 6}$ & $\mathbf{1 9 9 7}$ & $\mathbf{1 9 9 8}$ & $\mathbf{1 9 9 9}$ & $\mathbf{2 0 0 0}$ \\
\hline $\begin{array}{c}\text { População } \\
\text { Total }\end{array}$ & 910.975 & 924.617 & 938.670 & 952.758 & 966.700 \\
\hline $\begin{array}{c}\text { População } \\
\text { Urbana }\end{array}$ & 891.670 & 906.054 & 920.873 & 935.758 & 950.533 \\
\hline População rural & 19.305 & 18.563 & 17.797 & 17.000 & 16.167 \\
\hline $\begin{array}{c}\text { Taxa de } \\
\text { Urbanização }\end{array}$ & 97,88 & 97,99 & 98,10 & 98,22 & 98,33 \\
\hline
\end{tabular}

Fonte: SEADE 1999; IBGE 2000, 2001, 2002 
Campinas está a 680 metros de altitude, apresentando temperatura média de outubro a março de 22 a $24^{\circ} \mathrm{C}$ e de abril a setembro de 18 a $22^{\circ} \mathrm{C}$, sendo que a umidade relativa do ar no período de outubro a março é em torno de $77 \%$ e de abril a setembro em torno de $65 \%$. Dista $100 \mathrm{Km}$ de São Paulo (capital) e tem como cidades limítrofes: ao Norte Jaguariúna, ao Leste Pedreira, Morungaba e Valinhos, ao Sul Itapeva e Indaiatuba, a Oeste Monte Mor, ao Noroeste Sumaré, Hortolândia e Paulínia. Tem como distritos Nova Aparecida, Barão Geraldo, Sousas e Joaquim Egídio (CAMPINAS 2001 e SANASA 2001). É polo de uma Região Metropolitana formada por 19 municípios, somando uma população de 2,2 milhões de habitantes; é a mais nova Região Metropolitana do Estado de São Paulo, que foi criada pela Lei n. ${ }^{\circ}$ 870 de 29/06/2000. Os municípios que compõem essa Região Metropolitana são: Americana, Artur Nogueira, Campinas, Cosmópolis, Engenheiro Coelho, Holambra, Hortolândia, Indaiatuba, Itatiba, Jaguariúna, Monte-Mor, NovaOdessa, Paulínia, Pedreira, Santa Bárbara do Oeste, Santo Antônio da Posse, Sumaré, Valinhos e Vinhedo. 9\% Produto Interno Bruto (PIB) saem da região de Campinas, que também é responsável por $17 \%$ da produção industrial do Estado de São Paulo (EMPLASA 2001).

Campinas abriga o segundo maior aeroporto do país, o de Viracopos, com um fluxo anual de cargas embarcadas e desembarcadas de 154 mil toneladas. Tem notório destaque na área da ciência e da tecnologia, abrigando renomadas Universidades, como Universidade Estadual de Campinas UNICAMP, Pontifícia Universidade Católica de Campinas - PUCCAMP e Universidade Paulista - UNIP (EMPLASA 2001).

Em relação ao sistema de abastecimento de água, no que tange aos mananciais que abastecem a cidade, tem-se que o Rio Atibaia é responsável por $92 \%$ da produção e Rio Capivari responsável por $8 \%$ da produção, com uma captação que gira em torno de 4.500 litros de água por segundo. $O$ município conta com cinco Estações de Tratamento de Água, variando de 360 a 2.400 litros por segundo. O volume de água tratada por mês é de aproximadamente $8.036 .269 \mathrm{~m}^{3}$. O tratamento de água é o convencional 
parcialmente avançado e atende a aproximadamente $96 \%$ da população, por redes. O restante da população é abastecida com caminhões-pipa e torneiras coletivas. O sistema de abastecimento de água existente hoje é capaz de suprir, além da população atendida, mais de 150 mil habitantes (SANASA 2001).

Já em relação ao sistema de esgotamento sanitário, tem-se que o volume de esgoto coletado por mês é de $3.998 .584 \mathrm{~m}^{3}$, representando quase 90\% do esgoto gerado. O município conta com doze Estações de Tratamento de Esgoto - ETE, variando de 1,5 a 150 litros por segundo, perfazendo uma capacidade total de tratamento de aproximadamente 237 litros por segundo, no entanto, apenas $8,75 \%$ de seus esgotos são tratados. Parte dessas ETE's realiza tratamento primário e parte tratamento secundário. Os tipos de tratamento utilizados são: tanques Inhoff, fossa séptica, lagoas de estabilização, lodo ativado, aeração prolongada por batedores e lodo ativado convencional por lagoas aeradas. As bacias de esgotamento são: Bacia do Quilombo, Bacia do Atibaia e Bacia do Capivari.

No que tange à estruturação da gestão dos serviços de água e esgoto, a partir da criação da cidade em 1842, consta que teve seu primeiro abastecimento de água em 1875, através de chafarizes construídos no centro da cidade. Passados 4 anos, 1879, um grupo de cidadãos fundou a Companhia Campineira de Águas e Esgotos, a qual, em 1881, recebeu direito de exploração dos serviços por 60 anos, porém quando chegou em 1892 esse prazo foi aumentado por mais 90 anos (SANASA s.d.p.).

O abastecimento de água nas residências começou em 1891. Nesse tempo, Campinas era considerada modelo em relação ao sistema de abastecimento de água no pais, porém, em menos de 30 anos, o sistema de abastecimento tornou-se insuficiente, o que levou a concessionária a pedir ao poder público aumento de tarifas, as quais eram cobradas sem aferição de hidrômetros domiciliares. A proposta de aumento nas tarifas foi tida como descabida, sendo então essa companhia encampada pela Prefeitura em dezembro de 1923, nascendo portanto, em 1924, a Repartição de Águas e 
Esgotos-RAE, de responsabilidade da Prefeitura Municipal. Dez anos mais tarde, em 1934, a RAE passou a ser denominada de Diretoria de Águas e Esgotos - DAE. Assim é que essa Diretoria de Águas e Esgotos permaneceu até 1952 quando passou a Departamento de Água e Esgotos - DAE (SANASA 2001; s.d.p. ).

Em 1966, o DAE transforma-se em autarquia municipal e em 1974, em uma empresa de economia mista de capital aberto, a SANASA - Sociedade de Abastecimento de Água e Saneamento S.A., com 99,9\% das ações pertencentes à Prefeitura Municipal. Portanto, Campinas tem uma administração indireta, de direito privado, sendo a SANASA responsável pela produção, tratamento, e a distribuição de água, bem como pela coleta, tratamento e disposição do esgoto (SANASA 2000, 2001).

Campinas foi uma das primeiras cidades brasileiras a contar com coleta de esgotos. Por outro lado, é conhecida atualmente (ano 2001) como a cidade com os cursos d'água entre os mais poluídos do Estado de São Paulo e do Brasil, devido o seu baixo índice de tratamento de esgotos (SANASA s.d.p., 2000, 2001).

Assim, dando prosseguimento aos procedimentos metodológicos, destacam-se as políticas de governo voltadas ao saneamento básico para o período 1996-2000, sendo que a análise dos dados encontra-se no item 5.

As políticas de governo da prefeitura de Campinas, voltadas ao saneamento básico - água e esgoto, foram identificadas nos Planos Plurianuais, Leis de Diretrizes Orçamentárias e Orçamentos Anuais. Quanto às políticas de governo do órgão gestor dos serviços de água e esgoto, estas foram identificadas nos Orçamentos de Investimentos Anuais publicados junto ao orçamento da Prefeitura, no Planejamento Estratégico e nas respostas dos questionários aplicados a esse órgão.

Dessa forma, nos Planos Plurianuais da Prefeitura foram identificados programas, projetos e obras estabelecidos pela SANASA, uma vez que a Lei 
Orgânica de Campinas preconiza, em seu artigo 166, que: "a lei orçamentária anual compreenderá o orçamento de investimentos das empresas em que o município, direta ou indiretamente, detenha a maioria do capital social com direito a voto" (CAMPINAS 2001). Assim sendo, no Plano Plurianual, para o quadriênio de 1994 a 1997, pôde-se identificar os principais projetos para os serviços de água e esgoto.

Tabela 6. Projetos para 1994-1997, Campinas.

\begin{tabular}{|l|}
\hline Adutoras e Sub-adutoras; Reservatórios. \\
\hline Abastecimento e Esgotamento de Bairros e Favelas. \\
\hline Tratamento de Esgoto da Microbacia de Barão Geraldo e das Sub-bacias \\
\hline Samambaia e Costa e Silva; despoluição da Lagoa do Taquaral \\
\hline Estação de Tratamento de Esgoto Costa e Silva. \\
\hline
\end{tabular}

Fonte: CAMPINAS 1993, 1995a, 1996a.

Em resumo, as políticas de governo deste período, refletidas nas prioridades estabelecidas para o quadriênio 1994-1997, foram: Expansão e Manutenção do Sistema de Abastecimento de Água e do Sistema de Esgotamento Sanitário e Despoluição de Corpos D'água.

Já em relação ao Plano Plurianual do quadriênio 1998 - 2001, pôde-se identificar os seguintes programas, projetos e metas para os serviços de água e esgoto, constantes na tabela 7 . 
Tabela 7. Programa, Projetos e Metas para 1998-2001, Campinas

\begin{tabular}{|c|c|c|}
\hline Programas & $\begin{array}{l}\text { Projetos } \\
\end{array}$ & \begin{tabular}{|l} 
Metas \\
\end{tabular} \\
\hline $\begin{array}{l}\text { Manutenção e } \\
\text { Expansão do Sistema } \\
\text { de Abastecimento }\end{array}$ & $\begin{array}{l}\text { Captação e tratamento } \\
\text { Adução } \\
\text { Reservação } \\
\text { Subadução } \\
\text { Distribuição de água em bairros e favelas }\end{array}$ & 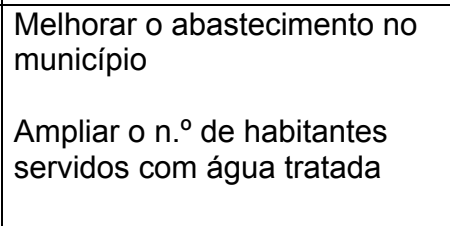 \\
\hline Otimização do Sistema & Desenvolvimento operacional & Redução e controle de perdas \\
\hline $\begin{array}{l}\text { Manutenção e } \\
\text { Expansão do Sistema } \\
\text { de Esgoto }\end{array}$ & $\begin{array}{l}\text { Interceptação e bombeamento } \\
\text { Coleta de esgoto em bairros e favelas } \\
\text { Tratamento de esgoto da bacia do Rio } \\
\text { Atibaia, do Rio Quilombo e do Rio } \\
\text { Capivari }\end{array}$ & $\begin{array}{l}\text { Ampliar o } n^{\circ} \text { de habitantes com } \\
\text { coleta e afastamento de esgoto } \\
\text { Ampliar a quantidade de esgoto } \\
\text { tratado }\end{array}$ \\
\hline
\end{tabular}

Fonte: Campinas 1997a, 1997b, 1998a, 1998b, 1999a.

Neste período, 1998 a 2001, percebe-se que, além daquelas prioridades estabelecidas para o período de 1994 a 1997, apareceu a preocupação com a otimização do sistema, visando o controle de perdas.

Assim, as políticas de governo identificadas para o período 1996 a 2000 foram: Manutenção e Expansão do Sistema de Abastecimento de Água e do Sistema de Esgotamento Sanitário, o Controle da Poluição Ambiental dos Corpos D’água e o Controle de Perdas do Sistema.

Ao estudar os orçamentos anuais da prefeitura e os orçamentos anuais do órgão gestor dos serviços de água e esgoto - SANASA, pôde-se identificar programas e projetos com estreitas relações entre a SANASA e a Prefeitura. Observou-se, por outro lado, se a Prefeitura estabelecia programas e projetos para o saneamento e qual Secretaria Municipal relacionava-se com esses programas e projetos. Identificou-se ainda o volume de recursos que esses programas e projetos representavam em relação ao orçamento dessa Secretaria, conforme segue na tabela 8. 
Tabela 8. Despesa da Secretaria Municipal com programas de saneamento básico, Campinas

\begin{tabular}{|c|c|c|c|c|c|}
\hline $\begin{array}{c}\text { Programa e/ou } \\
\text { Projeto }\end{array}$ & $\begin{array}{c}\text { Secretaria } \\
\text { responsável } \\
\text { pelo programa }\end{array}$ & $\begin{array}{l}\text { Orçamento } \\
\text { da Secretaria } \\
\text { (R\$) }\end{array}$ & $\begin{array}{l}\text { (\%) em relação } \\
\text { ao orçamento } \\
\text { total da } \\
\text { administração } \\
\text { direta }\end{array}$ & \multicolumn{2}{|c|}{$\begin{array}{c}\text { Orçamento do programa } \\
\text { em relação ao orçamento } \\
\text { da Secretaria }\end{array}$} \\
\hline \multicolumn{6}{|c|}{ ANO 1996 - Total Geral da Administração Direta $=489.364 .410,00$} \\
\hline $\begin{array}{l}\text { Saneamento da } \\
\text { Bacia do Anhumas }\end{array}$ & $\begin{array}{l}\text { Secretaria de } \\
\text { Obras }\end{array}$ & 65.151 .341 & 13,3135 & $15.168 .200,00$ & 23,2815 \\
\hline $\begin{array}{l}\text { Abastecimento de } \\
\text { Água }\end{array}$ & & & & $3.240 .000,00$ & \\
\hline \multicolumn{6}{|c|}{ ANO 1997 - Total Geral da Administração Direta $=567.032 .000,00$} \\
\hline \multicolumn{6}{|l|}{ Nada consta } \\
\hline \multicolumn{6}{|c|}{ ANO 1998 - Total Geral da Administração Direta $=659.819 .000,00$} \\
\hline \multicolumn{6}{|l|}{ Nada consta } \\
\hline \multicolumn{6}{|c|}{ ANO 1999 - Total Geral da Administração Direta $=685.112 .300,00$} \\
\hline \multicolumn{6}{|l|}{ Nada consta } \\
\hline \multicolumn{6}{|c|}{ ANO 2000 - Total Geral da Administração Direta $=678.838 .560,00$} \\
\hline Nada c & & & & & \\
\hline
\end{tabular}

Fonte: CAMPINAS 1995b, 1996b, 1997c, 1998b, 1999b.

Assim sendo, identificou-se que a Secretaria Municipal de Obras estabelecia, para o ano de 1996, o programa de saneamento do Anhumas. Os recursos para esse programa representavam cerca de $23 \%$ do volume de recursos dessa Secretaria. No entanto, para os anos de 1997 a 2000, não foram encontrados recursos para esse programa.

Ainda em relação ao estudo dos orçamentos anuais, buscou-se verificar a representatividade em termos percentuais do volume de recursos disponíveis pelo órgão gestor dos serviços de água e esgoto em relação ao orçamento da Prefeitura, conforme observa-se na tabela 9. Nota-se que esse percentual gira em torno de $15 \%$, exceto para os anos de 1997 e 2000 , considerado um valor bastante razoável se comparado como o percentual direcionado para Secretarias Municipais como é o caso da Secretaria de Serviços de Obras. 
Observado na tabela 8. Secretarias essas que geralmente têm atribuições diversas, que oneram o orçamento em percentuais elevados.

Tabela 9. Orçamento da Prefeitura e da SANASA, Campinas.

\begin{tabular}{|c|c|c|c|}
\hline Ano & $\begin{array}{c}\text { Total Geral da } \\
\text { Administração Direta }\end{array}$ & $\begin{array}{c}\text { Recursos disponíveis } \\
\text { para investimentos } \\
\mathbf{( R \$ )}\end{array}$ & $\begin{array}{c}\text { \% de recursos da } \\
\text { SANASA em relação } \\
\text { ao total geral da } \\
\text { administração }\end{array}$ \\
\hline 1996 & $489.364 .410,00$ & $65.701 .126,00$ & 13,43 \\
\hline 1997 & $567.032 .000,00$ & $31.897 .248,00$ & 5,63 \\
\hline 1998 & $659.819 .000,00$ & $94.704 .329,00$ & 14,35 \\
\hline 1999 & $685.112 .300,00$ & $104.414 .826,00$ & 15,24 \\
\hline 2000 & $678.838 .560,00$ & $50.000 .000,00$ & 7,37 \\
\hline
\end{tabular}

Fonte: CAMPINAS 1995b, 1996b, 1997c, 1998b, 1999b; SANASA 1997 a 2001.

Desse modo, pôde-se analisar a importância atribuída aos serviços de água e esgoto para a cidade por parte dos governantes, conforme descrito no item 5 Discussão dos Resultados.

Como mencionado anteriormente, o Planejamento Estratégico foi um instrumento utilizado também na identificação das políticas de governo dos órgãos gestores dos serviços de água e esgoto e, para tanto, buscou-se metas, diretrizes por ele estabelecidas, as quais serviram para a análise dessas políticas. Essas diretrizes e metas podem ser observadas na tabela 10. 
Tabela 10. Planejamento Estratégico - Metas para 1994 a 1996, Campinas.

\begin{tabular}{|c|c|}
\hline $\begin{array}{c}\text { OBJETIVOS / DIRETRIZES } \\
(1994-2004)\end{array}$ & $\begin{array}{c}\text { METAS } \\
(1994 \text { a 1996) }\end{array}$ \\
\hline $\begin{array}{l}\text { 1.Ter excelência na qualidade } \\
\text { dos serviços }\end{array}$ & Depende do alcance das demais metas \\
\hline $\begin{array}{l}\text { 2.Qualidade no atendimento, } \\
\text { cliente satisfeito }\end{array}$ & $\begin{array}{l}\text { 1. Redução dos prazos médios de atendimento aos clientes em } \\
30 \% \text {. } \\
\text { 2. Melhorar a qualidade dos serviços prestados a comunidade. } \\
\text { Ampliar o atendimento de água e esgoto. }\end{array}$ \\
\hline $\begin{array}{l}\text { 3.Obter resultados econômicos } \\
\text { para remuneração do capital, } \\
\text { expansão dos serviços e } \\
\text { valorização dos funcionários }\end{array}$ & $\begin{array}{l}\text { 1. Aumento de receita tarifária de } \mathrm{R} \$ 58,2 \text { milhões para } \mathrm{R} \$ 64 \\
\text { milhões, sem aumento real da tarifa. } \\
\text { 2. Aumento do volume faturado de } 71,4 \text { milhões de } \mathrm{m}^{3} \text { para } 75,8 \\
\text { milhões de } \mathrm{m}^{3} \text {. } \\
\text { 3. Geração e disponibilização de recursos tarifários na ordem de } \\
\text { U\$ } 4 \text { milhões/ano em } 1996 \text { e } 1997 \text {, para novos investimentos. } \\
\text { 4. Diminuir a inadimplência para } 10 \% \text { do faturamento e reduzir o } \\
\text { número de ligações inadimplentes de } 28.0000 \text { para } 14.000 \\
\text { ligações. } \\
\text { 5. Reduzir perdas no fornecimento. } \\
\text { 6. Reduzir custos e despesas operacionais de } \mathrm{R} \$ 51 \text { milhões para } \\
\text { R\$ } 46 \text { milhões. } \\
\text { 7. Faturar serviços de esgotos em } 100 \% \text { dos clientes com } \\
\text { captação própria de água, ligadas à rede de esgotos. } \\
\text { Implantação de um sistema de controle e eliminação das } \\
\text { ligações clandestinas da água e esgoto. }\end{array}$ \\
\hline $\begin{array}{l}\text { 4. Contribuir para a qualidade do } \\
\text { meio ambiente e preservação } \\
\text { dos recursos hídricos da região, } \\
\text { promovendo cooperação } \\
\text { regional }\end{array}$ & $\begin{array}{l}\text { 1. Tratar os esgotos dos setores Bosque de Barão Geraldo, Costa } \\
\text { e Silva e Amaraes, pertencentes à Bacia do Quilombo, } \\
\text { atendendo uma população de } 31.500 \text { habitantes, com coleta, } \\
\text { afastamento e tratamento. } \\
\text { 2. Contribuir para a redução da poluição orgânica dos municípios } \\
\text { de Valinhos e Vinhedo na Bacia do Ribeirão dos Pinheiros, } \\
\text { atuando nesses municípios no sentido de incentivar e cobrar } \\
\text { uma ação integrada para o tratamento de seus esgotos. } \\
\text { 3. Tratar os esgotos das Bacias do Samambaia, Chácaras } \\
\text { Primavera, Parque Jambeiro, bem como de sistemas } \\
\text { individuais, correspondendo ao atendimento de } 82.000 \\
\text { habitantes. } \\
\text { Fazer cumprir a legislação de controle ambiental das empresas } \\
\text { poluidoras. } \\
\text { Implantar legislação de tratamento de esgotos, em loteamento e } \\
\text { grandes empreendimentos. }\end{array}$ \\
\hline $\begin{array}{l}\text { 5. Ser empresa eficiente: baixo } \\
\text { custo, modernização } \\
\text { operacional, administrativo, } \\
\text { técnico, financeiro e comercial }\end{array}$ & $\begin{array}{l}\text { 1. Reduzir em } 10 \% \text { o peso de gastos com o pessoal próprio e } \\
\text { contratado, sobre o faturamento (situação atual pessoal próprio } \\
47,19 \% \text {, contratado } 2,55 \% \text { ). } \\
\text { 2. Reduzir o tempo entre a leitura do hidrômetro e o pagamento } \\
\text { em } 3 \text { dias. } \\
\text { 3. Cadastrar } 1.280 \mathrm{Km} \text { de rede de água; } 440 \mathrm{Km} \text { de rede de } \\
\text { esgoto; } 118 \mathrm{Km} \text { de adutoras; } 157 \mathrm{Km} \text { de rede emissários. } \\
\text { 4. Ter } 40 \% \text { do quadro funcional atuando em atividades meio e } \\
60 \% \text { em atividades fim. (situação atual } 52 \% \text { em atividade meio e } \\
48 \% \text { em atividade fim). } \\
\text { 5. Ter relatórios gerenciais contendo todos indicadores de } \\
\text { desempenho, com divulgação ampla e periódica. } \\
\text { 6. Automatizar } 12 \text { centros de reservação. } \\
\text { Determinar e implantar tempo padrão para todos os serviços } \\
\text { internos. }\end{array}$ \\
\hline $\begin{array}{l}\text { 6. Promover a conservação no } \\
\text { uso da água com baixos níveis } \\
\text { de perdas e desperdícios }\end{array}$ & $\begin{array}{l}\text { 1. Não ter vazamentos em reservatórios da empresa. } \\
\text { 2. Implantar sistema para mensurar perdas gerais de água na } \\
\text { Sanasa, instalando } 26 \text { estações pitométricas e } 30 \\
\text { macromedidores, } \\
\text { 3. Ter um programa de educação e esclarecimento do consumidor } \\
\text { com relação à conservação de água. }\end{array}$ \\
\hline
\end{tabular}




\begin{tabular}{|c|c|}
\hline $\begin{array}{l}\text { 7. Defender interesse } \\
\text { comunitário com a participação } \\
\text { da prefeitura, organizações } \\
\text { comunitárias e consumidores }\end{array}$ & \multirow{5}{*}{$\begin{array}{l}\text { "elementos de } 7 \text { a } 11 \text { não foram especificadas metas por serem } \\
\text { essencialmente qualitativos, não passíveis de quantificação" } \\
\text { Fonte: O Planejamento Estratégico na Sanasa, } 1996\end{array}$} \\
\hline $\begin{array}{l}\text { 8. Ter uma administração eficaz, } \\
\text { integrada, participativa com } \\
\text { controle efetivo }\end{array}$ & \\
\hline $\begin{array}{l}\text { 9. Administrar por objetivos e } \\
\text { metas consistentes com as } \\
\text { expectativas da comunidade }\end{array}$ & \\
\hline $\begin{array}{l}\text { 10. Deter e desenvolver } \\
\text { tecnologia }\end{array}$ & \\
\hline $\begin{array}{l}\text { 11. Ser uma empresa } \\
\text { informatizada, administrativa e } \\
\text { operacionalmente }\end{array}$ & \\
\hline $\begin{array}{l}\text { 12. Ter funcionários motivados, } \\
\text { capacitados e em número } \\
\text { compatível com a necessidade }\end{array}$ & $\begin{array}{l}\text { 1. Toda estrutura organizacional, processos e métodos de } \\
\text { trabalho, adequados as necessidades. } \\
\text { 2. Atingir toda empresa com o "Programa de Desenvolvimento } \\
\text { Profissional". } \\
\text { 3. Implantar o "Plano de Cargos, Salários e Benefícios". } \\
\text { 4. Implantar o "Sistema de Avaliação de Desempenho } \\
\text { Profissional", enfatizando indicadores de produtividade. } \\
\text { 5. Dimensionar quadro de pessoal da empresa. }\end{array}$ \\
\hline $\begin{array}{l}\text { 13. Ter acesso a recursos } \\
\text { financeiros para investimentos } \\
\text { na expansão e modernização }\end{array}$ & \\
\hline
\end{tabular}

Fonte: SANASA 1994.

Ainda em relação à identificação das políticas de governo, buscou-se os resultados obtidos por esse Planejamento Estratégico da SANASA, e que podem ser observados na tabela 11 a seguir. 
Tabela 11. Resultados do Planejamento Estratégico - ano 1996, Campinas.

Redução do tempo médio de atendimento à ligações de água: de 59 dias para 20 dias Redução do tempo médio de atendimento à ligações de esgoto: de 70 dias para 16 dias Crescimento no número de ligações novas faturadas no ano:

água de 3.179 para 5.333 e esgoto de 1.750 para 7.402

Diminuição no tempo entre leitura e pagamento da conta, de 24 dias para 21 dias

Criação de mais dois distritos de manutenção: Souzas e Parque Valença

Recuperação da capacidade de abastecimento dos bairros Vila Industrial e Vila Nogueira, que apresentavam problemas crônicos de desabastecimento

Redução de perdas físicas de água em dois bairros da cidade, de $55 \%$ para $32 \%$ e o outro de $43 \%$ para $32 \%$.

Redução de perdas físicas totais, de $41,2 \%$ para $35,7 \%$

Recuperação de perdas de faturamento com atuação em ligações clandestinas de água e esgotos, da ordem de $70 \%$

Recuperação de receita com programa de poços tubulares da ordem de $\mathrm{R} \$ 180.000$ por mês

Cadastro de $197 \mathrm{Km}$ de redes de água, $404 \mathrm{Km}$ de redes de esgoto, $103 \mathrm{Km}$ de adutoras e $159 \mathrm{Km}$ de emissários

Garantia de Abastecimento para os bairros Campo Grande, Londres, Eulina, Bonfim, Vila Teixeira, Chapadão, Taquaral, Barão Geraldo e Unicamp, a partir da execução do anel de macroadução

Diminuição no número de reclamações de por falta de água, de 41 reclamações por dia para 0, na região do Castelo, Bonfim, Chapadão e Cidade Universitária

Aumento da capacidade de captação no Atibaia em 500 litros por segundo, significando uma folga de abastecimento para mais 200 habitantes

Melhoria na qualidade da água com substituição do sulfato de alumínio por cloreto férrico no processo de tratamento

Existência de cadastro de acompanhamento de todas as obras realizadas por terceiros neste período

Resolução de diretoria, aprovada e implantada acerca da obrigatoriedade de tratamento de esgotos para novos empreendimentos. (projeto de lei aprovado na Câmara Municipal)

Aumento do faturamento anual de U\$ 53.510,95 para U\$ 106.153,61

Redução no índice de inadimplência de $20 \%$ para $13 \%$

Redução do fator mão de obra / receita total de $49,68 \%$ para $32,45 \%$

Criação de veículos de comunicação interna: Jornal Gota d'água, Comunicador e Sanasa informa

Valorização da empresa frente à população de Campinas, à partir de inserções em rádio e televisão; programas de preventiva junto aos bairros que recebem rede de água e esgoto

Divulgação das obras informando dos benefícios e também orientando quanto às interferências na região

Realização de treinamentos de funcionários: Treinamento de Encanadores; Treinamento em Comunicação; Atendentes Comerciais; Seminário Gerencial fora da empresa

Cursos desde a $1^{\text {a }}$ até a $8^{\mathrm{a}}$ série, para 115 funcionários por meio de convênio com o SESI.

Fonte: SANASA 1994, 1996

Em relação aos resultados alcançados para o período de 1997 a 2000, estes não estavam disponibilizados para consulta, pois o acompanhamento do Planejamento Estratégico da empresa, durante a gestão 1997-2000, foi paralisado. 
Dando continuidade aos procedimentos metodológicos, buscou-se finalmente, identificar os resultados das políticas de governo, período 1996 2000, em função das respostas do questionário aplicado na SANASA, como seguem na tabela 12.

Tabela 12. Informações sobre Água, Esgoto e População de Campinas, 1996-2000.

\begin{tabular}{|c|c|c|c|c|c|}
\hline \multirow[t]{2}{*}{ Informações } & \multicolumn{5}{|c|}{ ANO } \\
\hline & 1996 & 1997 & 1998 & 1999 & 2000 \\
\hline $\begin{array}{l}\text { População } \\
\text { urbana } \\
\text { município do } \\
\text { (hab.) }\end{array}$ & 891.670 & 906.054 & 920.873 & 935.758 & 950.533 \\
\hline $\begin{array}{l}\text { Acréscimo } \\
\text { populacional } \\
\text { urbano no ano } \\
\text { (hab.) }\end{array}$ & & 14.384 & 14.819 & 14.885 & 14.775 \\
\hline $\begin{array}{l}\text { Acréscimo da } \\
\text { população } \\
\text { atendida com } \\
\text { água tratada no } \\
\text { período (hab.) } \\
\text { (1) }\end{array}$ & & 32.880 & 8.062 & 8.385 & 9.243 \\
\hline $\begin{array}{lr}\text { Índice } & \text { de } \\
\text { Atendimento de } \\
\text { Água (\%) }\end{array}$ & 97,6 & 97,8 & 98,0 & 98,0 & 98,0 \\
\hline $\begin{array}{l}\text { Índice de } \\
\text { Hidrometração } \\
(\%)\end{array}$ & & 100,0 & 100,0 & 97,0 & 100,0 \\
\hline $\begin{array}{l}\text { líndice de } \\
\text { Perdas Físicas } \\
\text { (\%) }\end{array}$ & 33,8 & 34,7 & 31,4 & 27,7 & 26,7 \\
\hline $\begin{array}{l}\text { Consumo per } \\
\text { capita } \\
\text { L /hab. dia }\end{array}$ & 239,3 & 231,7 & 225,8 & 228,4 & 230,5 \\
\hline $\begin{array}{lr}\text { Extensão de } & \text { de } \\
\text { rede de água } \\
(\mathrm{Km}) & (\mathbf{1}) \\
\end{array}$ & 2870 & 2978 & 3081 & 3133 & 3164 \\
\hline $\begin{array}{l}\text { Implantação de } \\
\text { rede de água } \\
\text { no ano }(\mathrm{Km}) \\
\text { (1) }\end{array}$ & 69,1 & 89,9 & 20,2 & 20,9 & 23,1 \\
\hline $\begin{array}{l}\text { Volume de } \\
\text { água tratada } \\
\text { produzido } \\
\left(\mathrm{m}^{3} / \text { ano }\right) \quad(1)\end{array}$ & 112.164.362 & 114.615 .745 & 111.146.252 & 107.270.719 & 107.520 .307 \\
\hline $\begin{array}{l}\text { Volume de } \\
\text { água faturado } \\
\left(\mathrm{m}^{3} / \text { ano) (1) }\right.\end{array}$ & 78.257 .132 & 79.005 .622 & 79.145 .731 & 80.381 .466 & 81.213 .550 \\
\hline $\begin{array}{l}\text { Quantidades de } \\
\text { ligações ativas } \\
\text { de água (un.) } \\
\text { (2) }\end{array}$ & 183.165 & 189.885 & 193.954 & 199.702 & 205.175 \\
\hline
\end{tabular}




\begin{tabular}{|c|c|c|c|c|c|}
\hline $\begin{array}{l}\text { Quantidade de } \\
\text { economias } \\
\text { ativas } \\
\text { micromedidas } \\
\text { (un.) (2) }\end{array}$ & 296.596 & 306.625 & 321.184 & 337.260 & 348.150 \\
\hline $\begin{array}{lr}\text { Acréscimo da } \\
\text { população } \\
\text { atendida com } \\
\text { esgoto no ano } \\
\text { (hab.) }\end{array}$ & & 28.745 & 12.080 & 8.666 & 8.225 \\
\hline $\begin{array}{l}\text { Indice de } \\
\text { atendimento de } \\
\text { esgoto (\%) (1) }\end{array}$ & 86 & 86 & 89 & 89 & 88 \\
\hline $\begin{array}{l}\text { Indice de } \\
\text { esgoto tratado } \\
\text { (\%) }\end{array}$ & 1,68 & 2,08 & 2,34 & 4,80 & 5,63 \\
\hline $\begin{array}{l}\text { Extensão de } \\
\text { rede de esgoto } \\
(\mathrm{Km})\end{array}$ & 2.566 & 2.615 & 2.741 & 2802 & 2823 \\
\hline $\begin{array}{l}\text { Implantação de } \\
\text { rede esgoto no } \\
\text { ano }(\mathrm{Km}) \quad(1)\end{array}$ & 106,4 & 83,6 & 30,2 & 21,7 & 20,6 \\
\hline $\begin{array}{lr}\text { Volume } & \text { de } \\
\text { esgoto coletado } \\
\left(\mathrm{m}^{3} / \text { ano }\right) & (1) \\
\end{array}$ & 66.786 .758 & 67.340 .750 & 66.177.596 & 52.773 .514 & 51.694 .874 \\
\hline $\begin{array}{l}\text { Volume de } \\
\text { esgoto tratado } \\
\left(\mathrm{m}^{3} / \text { ano }\right)\end{array}$ & 1.124 .099 & 1.401 .235 & 1.545 .869 & 2.530 .932 & 2.910 .090 \\
\hline $\begin{array}{l}\text { Quantidades de } \\
\text { ligações de } \\
\text { esgoto (un.) (2) }\end{array}$ & 164.773 & 170.683 & 174.097 & 178.708 & 182.678 \\
\hline $\begin{array}{l}\text { Quantidades de } \\
\text { economias } \\
\text { ativas de } \\
\text { esgoto (un.) (2) }\end{array}$ & 263.763 & 272.471 & 279.646 & 291.369 & 298.342 \\
\hline $\begin{array}{l}\text { Investimento } \\
\text { em água } \\
\text { (R\$ / ano) (2) }\end{array}$ & $11.508 .542,00$ & $7.153 .076,00$ & 1.691 .366 & $1.542 .515,00$ & $1.309 .020,00$ \\
\hline $\begin{array}{l}\text { Receita } \\
\text { operacional dos } \\
\text { serviços de } \\
\text { água (R\$/ano) } \\
\text { (1) }\end{array}$ & $69.581 .000,00$ & $73.548 .000,00$ & $75.824 .000,00$ & $80.784 .000,00$ & $83.865 .000,00$ \\
\hline $\begin{array}{l}\text { Receita } \\
\text { operacional dos } \\
\text { serviços de } \\
\text { esgoto } \\
\text { (R\$/ano) (1) } \\
\end{array}$ & $56.654 .000,00$ & $57.506 .000,00$ & $59.819 .000,00$ & $66.391 .000,00$ & $74.880 .000,00$ \\
\hline $\begin{array}{l}\text { Total da receita } \\
\text { (água + esgoto) }\end{array}$ & $126.235 .000,00$ & $131.054 .000,00$ & $135.643 .000,00$ & $147.175 .000,00$ & $158.745 .000,00$ \\
\hline $\begin{array}{l}\text { Despesa } \\
\text { operacional dos } \\
\text { serviços de } \\
\text { água }(R \$ / a n o) \\
\text { (1) }\end{array}$ & $104.523 .000,00$ & $76.136 .000,00$ & $74.057 .000,00$ & $73.205 .000,00$ & $75.525 .000,00$ \\
\hline $\begin{array}{ll}\text { Despesa } & \\
\text { operacional } & \text { dos } \\
\text { serviços } & \text { de } \\
\text { esgoto } & \\
\text { (R\$/ano) } & \text { (1) } \\
\end{array}$ & $85.105 .000,00$ & $59.530 .000,00$ & $58.424 .000,00$ & $60.161 .000,00$ & $67.434 .000,00$ \\
\hline $\begin{array}{l}\text { Total da } \\
\text { despesa (água } \\
+ \text { esgoto) } \\
(\mathrm{R} \$ \text { /ano) (1) }\end{array}$ & $189.628 .000,00$ & $135.666 .000,00$ & $132.481 .000,00$ & $133.366 .000,00$ & $142.959 .000,00$ \\
\hline
\end{tabular}




\begin{tabular}{|l|c|c|c|c|c|}
\hline $\begin{array}{l}\text { Investimento } \\
\text { em } \\
\text { esgoto } \\
\text { (R\$/ ano) (2) }\end{array}$ & $14.182 .318,00$ & $6.836 .064,00$ & $17.452 .060,00$ & $19.334 .953,00$ & $4.662 .356,00$ \\
\hline $\begin{array}{l}\text { Investimento } \\
\text { disponível } \\
\text { apontado no } \\
\text { oçamento } \\
\text { anual (R\$) (4) }\end{array}$ & $65.701 .126,00$ & $31.897 .248,00$ & $94.704 .329,00$ & 104.414 .826 & $50.000 .000,00$ \\
\hline $\begin{array}{l}\text { Empregados } \\
\text { próprios (1) }\end{array}$ & 1.817 & 1.888 & 2.027 & 1.646 & 1.568 \\
\hline $\begin{array}{l}\text { Investimentos } \\
\text { em capacitação } \\
\text { de pessoal } \\
\text { (R\$/ano) (1) }\end{array}$ & $563.104,37$ & $484.677,74$ & $440.461,58$ & $336.089,36$ & $256.369,82$ \\
\hline
\end{tabular}

Fonte: (1) SANASA; (2) SNIS 1996 a 2000; (3) IBGE 2001, SEADE 1999; (4) DOM 1995 a 2000.

Observa-se nessa tabela que as informações não obtidas naquele órgão gestor foram levantadas em outras fontes, como o Sistema Nacional de Informações em Saneamento - SNIS, IBGE, SEADE e Prefeitura de Campinas, na Secretaria de Assuntos Jurídicos. As lacunas existentes justificam-se pela inexistência de informações no SNIS. É importante salientar que, ao pesquisar algumas informações do SNIS e confrontá-las com as obtidas dos gestores dos serviços de água e esgoto, diversas delas revelaram-se divergentes, levando a interpretações frágeis para a sua utilização.

Apresentados os resultados das políticas públicas, bem como das políticas de governo voltadas ao saneamento básico - água e esgoto - para o Município de Campinas, passa-se então, para os resultados alcançados para o Município de Santo André.

\subsubsection{Santo André - gestão dos serviços de água e esgoto no âmbito do município}

Santo André conta com uma população de 625.564 habitantes em seus $175 \mathrm{Km}^{2}$, resultando numa densidade demográfica de aproximadamente de 3.709 hab./Km² (IBGE 2002).

Segundo dados do SEADE (1999), a taxa de crescimento anual da população de Santo André, para o período 1991 - 2000, foi de 0,60\% a.a.. 
Como pode ser observado na tabela 13, Santo André é um município com população predominantemente urbana.

Tabela 13. Evolução da População do Município de Santo André.

\begin{tabular}{|c|c|c|c|c|c|}
\hline Ano & $\mathbf{1 9 9 6}$ & $\mathbf{1 9 9 7}$ & $\mathbf{1 9 9 8}$ & $\mathbf{1 9 9 9}$ & $\mathbf{2 0 0 0}$ \\
\hline $\begin{array}{c}\text { População } \\
\text { Total }\end{array}$ & 632.493 & 636.091 & 639.949 & 644.135 & 648.121 \\
\hline $\begin{array}{c}\text { População } \\
\text { Urbana }\end{array}$ & 632.493 & 636.091 & 639.949 & 644.135 & 648.121 \\
\hline $\begin{array}{c}\text { População } \\
\text { Rural }\end{array}$ & 0 & 0 & 0 & 0 & 0 \\
\hline $\begin{array}{c}\text { Taxa de } \\
\text { Urbanização }\end{array}$ & 100,00 & 100,00 & 100,00 & 100,00 & 100,00 \\
\hline
\end{tabular}

Fonte: SEADE 1999; IBGE 2000, 2001, 2002.

Santo André dista $18 \mathrm{Km}$ de São Paulo (capital) e faz parte da Região Metropolitana de São Paulo, tendo como municípios limítrofes: São Paulo, São Caetano, São Bernardo do Campo, Mauá, Ribeirão Pires, Rio Grande da Serra e Mogi das Cruzes. Mais da metade de seu território encontra-se em área de proteção de mananciais, abrigando parte das bacias formadoras do Rio Tamanduateí e da Represa Billings. Os mananciais de abastecimento do município são: os da região do Piracicaba - Sistema Cantareira, representando 64\%, o Rio Grande - Sistema Rio Grande, representando 32\%, e do Pedroso Bacia Biliings, representando 4\% (SEMASA, s.d.p.).

O município de Santo André conta com uma Estação de Tratamento de Água - ETA Guarará, cujo tratamento é cloração e fluoretação. O volume de água tratada fornecida por mês pelo município, atualmente, é de $4.650 .000 \mathrm{~m} 3$, sendo que $95 \%$ são tratados pela SABESP e 5\% pelo SEMASA. Em torno de 98\% da população urbana são atendidos com água tratada. O SEMASA compra a água por atacado da SABESP e distribui para o município.

Em relação ao esgoto, o município não conta com Estação de Tratamento de Esgotos. Os esgotos são tratados na ETE do $A B C$ região em São Paulo, na divisa com o município de São Caetano. A população atendida com rede coletora é de $96 \%$. O volume de esgoto coletado por ano no município, atualmente, é de aproximadamente $3.720 .000 \mathrm{~m}^{3}$. 
No que tange à estruturação dos serviços de água e esgoto, pode-se dizer que começou com a inauguração da estação férrea São Bernardo, em 1897, quando foi implantada a primeira adutora para servir às máquinas. $A$ partir do povoado que se formou ao redor dessa estação, é que nasceu o atual centro histórico da cidade. Surgiram então as primeiras instalações como a caixa d'água e o chafariz, no centro da cidade. Em 1910, o prefeito assinou o primeiro empréstimo para realizar obras de rede de água na cidade. Dois anos mais tarde foi criada uma seção na prefeitura para cuidar dos serviços de água e esgoto Em 1954, foi criado o Departamento de Água e Esgoto - DAE, da Prefeitura, para cuidar desses serviços de água e esgoto da cidade. Em 1969, com a modernização do DAE, nasceu o Serviço Municipal de Saneamento Ambiental - SEMASA. (PMSA 1996, 1990; SEMASA 2001).

O SEMASA é uma autarquia e, como órgão autônomo, não é subordinado à administração direta, no entanto está sujeito à coordenação, supervisão e controle dos seus atos por parte da administração municipal. Até 1997, o SEMASA cuidava apenas dos serviços relacionados ao abastecimento de água e coleta de esgotos. A partir desta data, encampou a responsabilidade de tratar das questões de drenagem urbana e vem, ao longo dos anos, aprimorando sua atuação, tendo, a partir de 1998, a atribuição de cuidar da gestão ambiental da cidade e, em 1999, das questões dos resíduos sólidos. Nesse ano, o SEMASA passa a ser conhecido como a primeira instituição do Brasil a cuidar do saneamento ambiental em todas as suas áreas: água, esgoto, drenagem, meio ambiente e resíduos sólidos. Em 2001, assume, também, a responsabilidade pela defesa civil do município. Assim, o SEMASA tem como funções planejar, projetar e executar os serviços referentes ao sistema de abastecimento de água, coleta de esgoto, ao trabalho de drenagem das águas pluviais, à proteção dos mananciais, à promoção da educação ambiental e ao cumprimento da legislação ambiental. É responsável ainda pelo licenciamento ambiental no âmbito do município (SEMASA 2001). 
Este caminho fez com que o município gradualmente atingisse uma forma pioneira no Brasil de gerir o saneamento ambiental, um modelo de gestão integrada.

Então, dando prosseguimento às questões metodológicas, passa-se a destacar as políticas de governo voltadas ao saneamento básico no período de 1996 a 2000.

As políticas de governo da Prefeitura de Santo André, voltadas ao saneamento básico - água e esgoto, foram identificadas nos Planos Plurianuais, Leis de Diretrizes Orçamentárias, Orçamentos Anuais e Planejamento Estratégico. Já para o órgão gestor dos serviços de água e esgoto, foram identificadas nos Orçamentos Anuais e no Planejamento Estratégico.

Procedendo conforme os mesmos passos descritos anteriormente para Campinas, têm-se para Santo André, nos Planos Plurianuais, as diretrizes que identificam as políticas de governo voltadas ao saneamento básico, como a seguir se descreve.

Do Plano Plurianual para o quadriênio de 1994 a 1997, o qual apresentou-se bastante sintético, puderam ser extraídos objetivos e metas para o saneamento básico conforme mostra a tabela13.

Tabela 13. Metas e Objetivos o Plano Plurianual, para 1994 a 1997, Santo André.

\begin{tabular}{|c|c|}
\hline OBJETIVOS & METAS \\
\hline $\begin{array}{l}\text { Melhoria e complementação do sistema } \\
\text { de abastecimento de água e coleta de } \\
\text { esgoto }\end{array}$ & $\begin{array}{l}\text { Construção de estação de recuperação } \\
\text { de água abrangendo serviços de esgotos } \\
\text { domésticos para produção de água } \\
\text { industrial, incluindo equipamentos. } \\
\text { Construção de estação de tratamento de } \\
\text { água ou ampliação da Estação de } \\
\text { Tratamento de Água - Guarará. }\end{array}$ \\
\hline
\end{tabular}

Fonte: SANTO ANDRÉ 1993.

Já no Plano Plurianual do período 1998 a 2001, pôde-se identificar os objetivos e metas para os serviços de água e esgoto, estabelecidos por parte do SEMASA, conforme observa-se na tabela 14. 
Tabela 14 . Metas e Objetivos do Plano Plurianual, para 1998 a 2001, Santo André.

\begin{tabular}{|l|l|}
\hline \multicolumn{1}{|c|}{ OBJETIVOS } & \multicolumn{1}{|c|}{ METAS } \\
\hline Melhoria e complementação do sistema de projetos e obras para implantação \\
da ETA $500 \mathrm{I} / \mathrm{s} ;$ \\
abastecimento de água; & $\begin{array}{l}\text { Executar obras de rede de água e esgoto em } \\
\text { Paranapiacaba; } \\
\text { Executar as obras de rede de água esgoto e } \\
\text { drenagem urbana no empreendimento da } \\
\text { CDHU no jardim Santo André, em } \\
\text { atendimento a convênio firmado entre a } \\
\text { coleta de esgotos. }\end{array}$ \\
$\begin{array}{l}\text { Exefeitura e o Governo do Estado; } \\
\text { Executar os projetos e obras de saneamento } \\
\text { integrado para as favelas do município; } \\
\text { Elaboração de projetos e execução de } \\
\text { extensão de redes de água, esgoto e } \\
\text { drenagem urbana nas áreas ainda não } \\
\text { atendidas pelo Semasa; } \\
\text { Elaboração de estudos de viabilidade, } \\
\text { projeto e obra de sistemas de reuso de água } \\
\text { para fins industriais; } \\
\text { Elaborar os projetos dos coletores-tronco } \\
\text { definidos no Plano Diretor de esgotos } \\
\text { sanitários }\end{array}$ \\
\hline
\end{tabular}

Fonte: SANTO ANDRÉ 2001.

Quanto às Leis de Diretrizes Orçamentárias de Santo André, estas apresentam-se de forma muito sucinta, trazendo apenas a palavra saneamento básico como uma das prioridades da administração municipal, para os anos de 1996 e 1997. Já para os anos de 1998 a 2000, traz a seguinte diretriz: Desenvolvimento de Políticas na Área de Saneamento Básico.

Ao estudar os orçamentos anuais da prefeitura e os orçamentos anuais do órgão gestor dos serviços de água e esgoto - SEMASA, pôde-se identificar programas e projetos com estreitas relações entre a SEMASA e a Prefeitura. Observou-se, por outro lado, se a Prefeitura estabelecia programas e projetos para o saneamento básico, cuja Secretaria Municipal relacionava-se com esses 
programas e projetos. Identificou-se ainda o volume de recursos que esses programas e projetos representavam em relação ao orçamento da Prefeitura, conforme segue na tabela 15.

Tabela 15. Despesa da Secretaria Municipal com Programas para o Saneamento Básico, Santo André.

\begin{tabular}{|c|c|c|c|c|c|}
\hline $\begin{array}{l}\text { Programa e/ou } \\
\text { Projeto }\end{array}$ & $\begin{array}{c}\text { Secretaria } \\
\text { responsável pelo } \\
\text { programa }\end{array}$ & $\begin{array}{l}\text { Orçamento da } \\
\text { Secretaria }\end{array}$ & $\begin{array}{c}\text { (\%) em relação } \\
\text { ao orçamento } \\
\text { total da } \\
\text { administração } \\
\text { direta }\end{array}$ & \multicolumn{2}{|c|}{$\begin{array}{c}\text { Orçamento do } \\
\text { programa e (\%) } \\
\text { em relação ao } \\
\text { orçamento da } \\
\text { Secretaria } \\
(\%)\end{array}$} \\
\hline \multicolumn{6}{|c|}{ ANO 1996 - Total Geral da Administração Direta $=274.141 .880,00$} \\
\hline $\begin{array}{l}\text { Sistemas de } \\
\text { Esgotos }\end{array}$ & $\begin{array}{l}\text { Secretaria de } \\
\text { Obras e serviços } \\
\text { Urbanos }\end{array}$ & $60.169 .670,00$ & 21,9484 & $9.000,00$ & 0,0150 \\
\hline \multicolumn{6}{|c|}{ ANO 1997 - Total Geral da Administração Direta = 339.742.290,00 } \\
\hline \multicolumn{6}{|l|}{ Não consta } \\
\hline \multicolumn{6}{|c|}{ ANO 1998 - Total Geral da Administração Direta = 356.039.530,00 } \\
\hline \multicolumn{6}{|l|}{ Não consta } \\
\hline \multicolumn{6}{|c|}{ ANO 1999 - Total Geral da Administração Direta = 419.669.800,00 } \\
\hline \multicolumn{6}{|l|}{ Não consta } \\
\hline \multicolumn{6}{|c|}{ ANO 2000 - Total Geral da Administração Direta $=406.740 .520,00$} \\
\hline Não consta & & & & & \\
\hline
\end{tabular}

Fonte: SANTO ANDRÉ 1995 a 1999.

Portanto observa-se na tabela 15 que a Secretaria Municipal de Obras e Serviços Urbanos estabelecia para o ano de 1996 o programa - Sistemas de Esgoto para a cidade de Santo André. No entanto, um valor bastante pequeno $(0,015 \%)$, dos recursos dessa Secretaria.

Ainda em relação ao estudo dos orçamentos anuais, buscou-se verificar a representatividade em termos percentuais do volume de recursos disponíveis pelo órgão gestor dos serviços de água e esgoto em relação ao orçamento da prefeitura, conforme observa-se na tabela 16. Nota-se que esse percentual gira em torno de $22 \%$ e que, conforme já mencionado, é um valor bastante razoável se comparado como o percentual direcionado para Secretarias Municipais, que 
geralmente têm diversas atribuições que oneram o orçamento em elevados percentuais.

Tabela 16. Orçamento da Prefeitura e do SEMASA, Santo André.

\begin{tabular}{|l|c|c|c|}
\hline Ano & $\begin{array}{c}\text { Total Geral da } \\
\end{array}$ & $\begin{array}{c}\text { Administração Direta } \\
\text { (R\$) }\end{array}$ & \multicolumn{2}{|c|}{ Recursos Próprios do SEMASA (R\$) } \\
\cline { 3 - 4 } & $274.141 .880,00$ & $60.873 .871,61$ & $\begin{array}{l}\text { Total em relação ao } \\
\text { total da } \\
\text { Administração }\end{array}$ \\
\hline 1996 & $339.742 .290,00$ & $66.323 .190,00$ & 19,5 \\
\hline 1997 & $356.039 .530,00$ & $94.586 .000,00$ & 26,6 \\
\hline 1998 & $419.669 .800,00$ & $89.800 .000,00$ & 21,4 \\
\hline 1999 & $406.740 .520,00$ & $76.430 .000,00$ & 18,8 \\
\hline 2000 & & & \\
\hline
\end{tabular}

Fonte: SANTO ANDRÉ 1995 a 1999; SEMASA 1997 a 2000.

No orçamento de investimentos do SEMASA, estabelecido no orçamento anual de 1996 e 1997 da Prefeitura, não aparece o detalhamento dos projetos de serviços de água e esgoto para o município, trazendo somente o montante da despesa fixada para o Semasa.

Buscou-se, ainda, identificar as políticas de governo no planejamento estratégico que, tanto a Prefeitura como o SEMASA, vêm utilizando. Em relação ao Planejamento Estratégico do SEMASA, resgatou-se somente o material de 1997 intitulado "Seminário de Implantação do Planejamento Estratégico" onde constavam as ações prioritárias por departamento, não constando de forma explícita metas e resultados (SEMASA 1997). Os documentos sobre o planejamento estratégico que contemplam o período 1996-2000 não estavam disponíveis, pois não foram arquivados, inviabilizando o levantamento sobre os objetivos, metas e resultados do período de estudo.

Quanto ao planejamento estratégico da prefeitura, este vem sendo implementado por meio do projeto Cidade Futuro, no qual o SEMASA compartilha objetivos, diretrizes estratégicas e metas. A elaboração do projeto Cidade Futuro iniciou-se em 1999, tendo-se construído cenários para um futuro desejado, que para tal foram divididos em grupos temáticos: desenvolvimento econômico, desenvolvimento urbano; qualidade ambiental; inclusão social; 
educação; identidade cultural; reforma do Estado. "Buscar a universalização do serviço de distribuição de água e coleta de esgoto. Preservar a água potável para fins de abastecimento humano, estimulando usos alternativos aos demais setores" (PMSA 2001). Esse projeto estava em pleno vapor, na ocasião da coleta de dados dessa pesquisa, não tendo alcançado por essa pesquisa a fase de resultados das ações (PMSA 2001a, 2001c). Desta forma, na tabela 17, apresentam-se metas e ações em andamento, relacionadas ao sistema de abastecimento de água e esgotamento sanitário.

Tabela 17. Metas e Ações para o Saneamento - Projeto Cidade Futuro, Santo André.

\begin{tabular}{|c|c|c|}
\hline METAS & AÇÕES EM ANDAMENTO & $\begin{array}{l}\text { AÇÕES A CURTO E MÉDIO PRAZOS } \\
\text { Curto = até } 2 \text { anos; Médio= de } 5 \text { a } 10 \\
\text { anos }\end{array}$ \\
\hline $\begin{array}{l}\text { Melhorar a qualidade dos } \\
\text { rios e córregos }\end{array}$ & $\begin{array}{l}\text { Estudo para determinar a qualidade das } \\
\text { águas dos rios de Santo André, base } \\
\text { para diagnóstico e estabelecimentos de } \\
\text { indicadores. }\end{array}$ & $\begin{array}{l}\text { Complementação dos coletores troncos } \\
\text { implantados pela SABESP no município } \\
\text { e início de operação do sistema, } \\
\text { incluindo o tratamento pela ETE ABC. }\end{array}$ \\
\hline $\begin{array}{l}\text { Reduzir } 100 \% \text { as doenças } \\
\text { de veiculação hídrica }\end{array}$ & 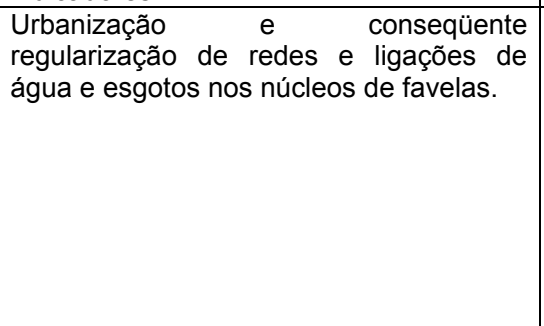 & $\begin{array}{l}\text { Revisão das leis de mananciais com } \\
\text { implantação da lei específica para a } \\
\text { Billings. } \\
\text { Quando autorizados, implantar, nas } \\
\text { áreas de proteção aos mananciais, } \\
\text { sistemas de saneamento adequados, } \\
\text { água e esgotos, e, caso contrário, } \\
\text { ampliar a orientação à população usuária } \\
\text { de sistemas alternativos de tratamento de } \\
\text { esgotos. }\end{array}$ \\
\hline $\begin{array}{l}\text { Recuperar e preservar a } \\
\text { qualidade das águas da } \\
\text { bacia Billings }\end{array}$ & $\begin{array}{l}\text { Proposta de remanejamento das redes } \\
\text { de esgotos danificadas do Parque Miami } \\
\text { e Jardim Riviera, fiscalização e educação } \\
\text { ambiental. }\end{array}$ & $\begin{array}{l}\text { Quando autorizados, implantar, nas } \\
\text { áreas de proteção aos mananciais, } \\
\text { sistemas de saneamento adequados, } \\
\text { água e esgotos, e, caso contrário, } \\
\text { ampliar a orientação à população usuária } \\
\text { de sistemas alternativos de tratamento de } \\
\text { esgotos. }\end{array}$ \\
\hline $\begin{array}{l}\text { Adequar os hábitos da } \\
\text { população à disponibilidade } \\
\text { hídrica }\end{array}$ & Campanha de redução de desperdício & $\begin{array}{l}\text { Promover ações e/ou campanhas } \\
\text { educativas, tanto na mídia quanto nos } \\
\text { fóruns já existentes. }\end{array}$ \\
\hline $\begin{array}{l}\text { Adequar a capacidade } \\
\text { física das instalações, } \\
\text { otimizando investimentos }\end{array}$ & $\begin{array}{l}\text { Fase final de implantação o sistema de } \\
\text { telemetria e telecomando de todo o } \\
\text { sistema de abastecimento. }\end{array}$ & $\begin{array}{l}\text { Substituir as redes antigas, continuar a } \\
\text { implantação do plano diretor de } \\
\text { abastecimento de água, bem como a } \\
\text { revisão do mesmo para demais } \\
\text { intervenções. }\end{array}$ \\
\hline $\begin{array}{l}\text { Aumentar o volume de } \\
\text { esgotos tratados, buscando } \\
\text { a universalização do } \\
\text { tratamento }\end{array}$ & $\begin{array}{l}\text { Será reiniciada a obra de coletores- } \\
\text { tronco pela SABESP. }\end{array}$ & $\begin{array}{l}\text { Complementação dos coletores troncos } \\
\text { implantados pela Sabesp no município. }\end{array}$ \\
\hline 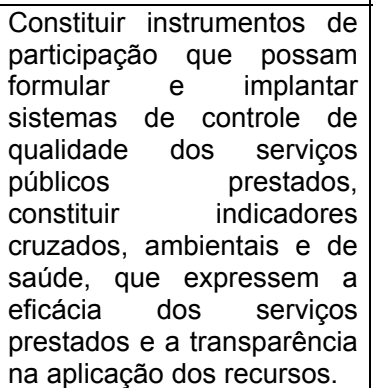 & $\begin{array}{l}\text { Elaboração do Plano Municipal de } \\
\text { Gestão e Saneamento Ambiental. }\end{array}$ & \\
\hline
\end{tabular}

Fonte: PMSA 2001b. 
Dando continuidade aos procedimentos metodológicos, buscou-se, finalmente, identificar os resultados das políticas de governo, período 1996 2000, em função das respostas do questionário aplicado no SEMASA, como seguem na tabela 18.

Tabela 18. Informações sobre Água, Esgoto e População de Santo André, 19962000.

\begin{tabular}{|c|c|c|c|c|c|}
\hline \multirow[t]{2}{*}{ Informações } & \multicolumn{5}{|c|}{ ANO } \\
\hline & 1996 & 1997 & 1998 & 1999 & $2000 \quad(2)$ \\
\hline $\begin{array}{l}\text { População do } \\
\text { município } \\
\text { (hab.) }\end{array}$ & 632.493 & 636.091 & 639.949 & 644.135 & 625.564 \\
\hline $\begin{array}{l}\text { Acréscimo } \\
\text { populacional no } \\
\text { ano (hab.) }\end{array}$ & & 3598 & 3858 & 4186 & -18571 \\
\hline $\begin{array}{l}\text { Acréscimo da } \\
\text { população } \\
\text { atendida com } \\
\text { água tratada no } \\
\text { período (hab.) } \\
\qquad \begin{array}{c}\text { (2) } \\
\end{array}\end{array}$ & & 5574 & 14819 & 11319 & 0 \\
\hline $\begin{array}{l}\text { Índice de } \\
\text { Atendimento de } \\
\text { Água (\%) } \\
\qquad \text { (2) }\end{array}$ & 99 & 99 & 98 & 96 & 96 \\
\hline $\begin{array}{l}\text { Índice de } \\
\text { Hidrometração } \\
(\%) \quad(2)\end{array}$ & - & 96 & 96 & 96 & 97 \\
\hline $\begin{array}{l}\text { Consumo per } \\
\text { capita } \\
\text { L /hab. dia } \\
\qquad\end{array}$ & 67,3 & 173,8 & 181,4 & 181,3 & 178,1 \\
\hline $\begin{array}{l}\text { Tarifa média } \\
\text { praticada (R\$/ } \\
\text { m3) }\end{array}$ & - & 0,82 & 0,85 & 0,93 & 0,99 \\
\hline $\begin{array}{l}\text { Extensão de } \\
\text { rede de água } \\
(\mathrm{Km}) \quad(\mathbf{1})\end{array}$ & 1.652 & 1.665 & 1680 & 1.696 & 1710 \\
\hline $\begin{array}{l}\text { Implantação de } \\
\text { rede de água } \\
\text { no ano }(\mathrm{Km}) \\
(1) \text { e (2) }\end{array}$ & 4,1 & 13,6 & 14,6 & 15,3 & 14,0 \\
\hline $\begin{array}{l}\text { Volume de } \\
\text { água tratada } \\
\text { aduzida } \\
\left(\mathrm{m}^{3} / \text { ano) }\right.\end{array}$ & & 57.315 .581 & 59.032 .146 & 57.394 .740 & 55.672 .100 \\
\hline $\begin{array}{l}\text { Volume de } \\
\text { água faturado } \\
\left(\mathrm{m}^{3} / \text { ano }\right)(1) \mathrm{e} \\
(2)\end{array}$ & 17.731 .500 & 43.070 .000 & 39.978 .800 & 39.514 .6000 & 38.113 .100 \\
\hline $\begin{array}{l}\text { Quantidades de } \\
\text { ligações ativas } \\
\text { de água (un.) } \\
\text { (2) }\end{array}$ & 144.000 & 144.949 & 147.082 & 148.820 & 149.395 \\
\hline $\begin{array}{l}\text { Quantidade de } \\
\text { economias } \\
\text { ativas } \\
\text { micromedidas } \\
\text { (un.) (2) }\end{array}$ & 182.330 & 218.596 & 224.282 & 226.907 & 236.972 \\
\hline $\begin{array}{l}\text { Acréscimo da } \\
\text { população } \\
\text { atendida com } \\
\text { esgoto no ano } \\
\text { (hab.) (2) }\end{array}$ & & 717 & 541 & 2888 & \\
\hline
\end{tabular}




\begin{tabular}{|c|c|c|c|c|c|}
\hline $\begin{array}{l}\text { Índice de } \\
\text { atendimento de } \\
\text { esgoto (\%) } \\
\text { (2) }\end{array}$ & 96 & 97 & 96 & 96 & 93 \\
\hline $\begin{array}{l}\text { Índice de } \\
\text { esgoto tratado } \\
(\%)\end{array}$ & 0 & 0 & 0 & 0 & 0 \\
\hline $\begin{array}{l}\text { Extensão de } \\
\text { rede de esgoto } \\
(\mathrm{Km}) \quad(1)\end{array}$ & 1014 & 1020 & 1.025 & 1.031 & 1.034 \\
\hline $\begin{array}{l}\text { Implantação de } \\
\text { rede esgoto no } \\
\text { ano }(\mathrm{Km}) \quad(1)\end{array}$ & 4,8 & 5,9 & 5,8 & 5,5 & \\
\hline $\begin{array}{l}\text { Volume de } \\
\text { esgoto coletado } \\
\left(\mathrm{m}^{3} / \text { ano }\right)\end{array}$ & 41.756 .000 & 39.529 .500 & 52.264 .000 & 38.701 .200 & 32.083 .900 \\
\hline $\begin{array}{l}\text { Volume de } \\
\text { esgoto faturado } \\
\left(\mathrm{m}^{3} / \text { ano }\right)\end{array}$ & 41.756 .000 & 39.529 .500 & 35.350 .100 & 38.701 .200 & 31.769 .600 \\
\hline $\begin{array}{l}\text { Volume de } \\
\text { esgoto tratado } \\
\left(\mathrm{m}^{3} / \text { ano }\right)\end{array}$ & & & 0 & 0 & 0 \\
\hline $\begin{array}{l}\text { Quantidades de } \\
\text { ligações de } \\
\text { esgoto (un.) (2) }\end{array}$ & 139.000 & 140.558 & 143.344 & 145.658 & 148.049 \\
\hline $\begin{array}{l}\text { Quantidades de } \\
\text { economias } \\
\text { ativas de } \\
\text { esgoto (un.) (2) }\end{array}$ & 175.890 & 211.802 & 217.733 & 225.793 & 230.013 \\
\hline $\begin{array}{l}\text { Receita } \\
\text { operacional dos } \\
\text { serviços de } \\
\text { água ( } \mathrm{R} \$ \text { / } \\
\text { ano) }\end{array}$ & & & $26.826 .853,20$ & $29.586 .085,75$ & $28.381 .010,42$ \\
\hline $\begin{array}{l}\text { Receita } \\
\text { operacional dos } \\
\text { serviços de } \\
\text { esgoto } \\
\text { (R\$/ano) (1) }\end{array}$ & & & $30.149 .389,37$ & $33.793 .041,64$ & $32.749 .913,99$ \\
\hline $\begin{array}{l}\text { Despesa } \\
\text { operacional dos } \\
\text { serviços de } \\
\text { esgoto }(\mathrm{R} \$ \text { / } \\
\text { ano) }\end{array}$ & & & $108.947 .142,32$ & $69.386 .835,69$ & $80.530 .110,03$ \\
\hline $\begin{array}{l}\text { Investimento } \\
\text { em esgoto } \\
(\mathrm{R} \$ \text { / ano) }\end{array}$ & 4.278 .000 & 6.099 .000 & 303.077 & 356.283 & 451.583 \\
\hline $\begin{array}{l}\text { Investimento } \\
\text { em água } \\
\text { (R\$ / ano) }\end{array}$ & 29.397.000 & 918.000 & 3.245 .216 & 2.137 .750 & 786.935 \\
\hline $\begin{array}{l}\text { Investimento } \\
\text { disponível } \\
\text { apontado no } \\
\text { orçamento } \\
\text { anual (R\$) (4) }\end{array}$ & $60.873 .871,61$ & $66.323 .190,00$ & $94.586 .000,00$ & $89.800 .000,00$ & $76.430 .000,00$ \\
\hline $\begin{array}{l}\text { Empregados } \\
\text { próprios }\end{array}$ & 985 & 987 & 1078 & 1361 & 1367 \\
\hline
\end{tabular}

Fonte: (1) SEMASA; (2) SNIS 1996 a 2000; (3) IBGE 2001; (4) Diário Oficial 1995 a 2000.

Observa-se nessa tabela 18 que as informações não obtidas naquele órgão gestor foram levantadas em outras fontes, como o Sistema Nacional de Informações em Saneamento - SNIS, IBGE, e no Diário Oficial do Município Câmara Municipal. As lacunas existentes, nessa tabela, justificam-se pela 
inexistência também das informações no SNIS. É importante salientar que, ao pesquisar algumas informações do SNIS e confrontá-las com as obtidas dos gestores dos serviços de água e esgoto, diversas delas revelaram-se divergentes, levando a interpretações frágeis para a sua utilização.

Como se vê, foram identificados os resultados gerados em função das políticas públicas e de governo para os Municípios de Campinas e Santo André, cuja responsabilidade da gestão dos serviços de água e esgoto é de âmbito municipal.

Dando prosseguimento à apresentação dos resultados, destacam-se a seguir, aqueles alcançados para os municípios de São José dos Campos e Santos.

\subsubsection{São José dos Campos e Santos - gestão dos serviços de água e esgoto no âmbito do Estado}

Neste item, serão apresentados os resultados das políticas de governo para os Municípios de São José dos Campos e Santos, cuja responsabilidade pela gestão dos serviços de água e esgoto é da Companhia de Saneamento Básico do Estado de São Paulo - SABESP, portanto de âmbito estadual. Assim, antes de adentrar os resultados das políticas de governo desses dois municípios, apresentam-se dados gerais sobre essa Companhia, no contexto dessa pesquisa.

\subsubsection{1. Órgão gestor dos serviços de água e esgoto do Estado de São Paulo - SABESP}

A SABESP foi criada em junho de 1973, com a fusão da Companhia Metropolitana de Água de São Paulo - COMASP (responsável pelo sistema de abastecimento de água das cidades da Região Metropolitana), da Companhia Metropolitana de Esgoto - SANESP (responsável pelo sistema de tratamento e disposição dos esgotos da Grande São Paulo), da absorção da totalidade do patrimônio da Superintendência de Água e Esgotos da Capital - SAEC 
(responsável pelos serviços de distribuição de água e coleta de esgotos da capital paulista) e parte do patrimônio da Companhia de Saneamento da Baixada Santista - SBS, da Companhia Regional do Vale do Ribeira SANEVALE, e do Fomento Estadual do Saneamento Básico - FESB (PEGORARO 1986).

A SABESP nasceu com a missão de planejar, executar e operar os serviços de saneamento básico de todo o território do Estado de São Paulo. Este fato deveu-se ao advento do Plano Nacional de Saneamento - PLANASA, instituído pelo governo federal, em 1971. É uma empresa de economia mista, de capital aberto, sendo seu principal acionista o governo do Estado de São Paulo - Concessionária de Serviços Municipais. Como empresa de economia mista, recebe atribuições estatais por delegação. Em 1994, por decorrência de uma crise financeira, essa Companhia elabora um novo modelo de gestão, almejando maior proximidade com os municípios que são os poderes concedentes. Esse novo modelo de gestão, adotado pela Companhia a partir de 1995, foi o de regionalização por Bacia Hidrográfica, tendo sido criadas então as Unidades de Negócios - UN, descentralizando as decisões para a aplicação dos recursos, de acordo com as diretrizes da SABESP central (SABESP 2001). Desse modo, conta com quatorze Unidades de Negócios gerenciadas por meio de três Vice-Presidências distribuídas da seguinte forma: Vice-Presidência da Região Metropolitana, que controla as Unidades de Negócios: Centro, Norte, Sul, Leste e Oeste, as quais atendem 37 municípios. Vice-Presidência Litoral, que controla as Unidades de Negócios: da Baixada Santista, do Vale do Ribeira e do Litoral Norte, as quais atendem 31 municípios.

Vice-Presidência Interior, que controla as Unidades de Negócios: do Vale do Paraíba, do Médio Tietê, do Baixo Tietê e Grande, do Alto Paranapanema, do Baixo Paranapanema e do Pardo e Grande, as quais atendem 298 municípios.

A SABESP atende, atualmente, 366 municípios do Estado de São Paulo, variando entre pequeno e grande porte. 
Este novo modelo de gestão conta com um Sistema de Gestão Regional constituído por meio de uma Assembléia de Municípios, uma Comissão de Gestão Regional e uma Unidade de Negócio, visando a proximidade com o poder concedente nas discussões da empresa. A Assembléia dos Municípios é composta pelos prefeitos dos municípios concedentes pertencentes à Unidade de Negócio e a Comissão de Gestão Regional por cinco representantes dos municípios concedentes, eleitos pela Assembléia, e cinco representantes da SABESP. Cabe à Assembléia dos Municípios eleger seus representantes na Comissão de Gestão Regional; decidir sobre balancetes, planos de investimentos, orçamentos, aprovar estatuto e o regimento do Sistema de Gestão Regional, dentre outras. À Comissão de Gestão Regional cabe: discutir balancetes regionais, plano de investimentos, orçamentos, acompanhar o desempenho operacional da Unidade de Negócio Regional, elaborar e propor estatuto e regimento do Sistema de Gestão Regional. Esta forma de participação dos municípios está sendo formalizado por novos modelos de contrato de concessão (SIMÕES 1998).

Para desenvolver suas atividades, a SABESP vem utilizando o planejamento estratégico, instrumento para estabelecer sua missão, diretrizes estratégicas e metas empresariais orientando, assim, os planejamentos táticos e operacional. O processo de planejamento é realizado e revisado anualmente para um horizonte de cinco anos. As metas são divididas em três blocos: atendimento ao cliente, eficiência operacional e econômico-financeira. São desagregadas até o nível regional por unidades de negócios (SIMÕES 1998). As metas estabelecidas e resultados alcançados pela SABESP, bem como alguns indicadores de desempenho da Companhia, englobam o período de estudo, 1996 a 2000 (SABESP 2002).

Dando continuidade aos procedimentos metodológicos, passa-se à apresentação dos resultados alcançados na identificação das políticas de governo do período de 1996 - 2000, do órgão gestor dos serviços de água e esgoto - SABESP. Uma vez que os Municípios de São José dos Campos e Santos são operados pela mesma Companhia, a descrição dos fatos a seguir, 
em relação à identificação dessas políticas nos Planos Plurianuais, Leis de Diretrizes Orçamentárias, Leis Orçamentarias Anuais vale para esses dois municípios.

Assim, as políticas de governo do órgão gestor desses serviços foram identificadas apenas nas respostas dos questionários, pois o ao Plano Plurianual de Investimentos desse órgão gestor não foi disponibilizado. Por outro lado, como a SABESP está submetida ao controle do Governo do Estado e que, conforme preconiza a Constituição Paulista de 1989, os orçamentos de investimentos das sociedades em que o Estado detenha, direta ou indiretamente, a maioria do capital social com direito a voto devem orientar-se pelas disposições das Leis de Diretrizes Orçamentárias, buscou-se então estudar os Planos Plurianual, Leis de Diretrizes Orçamentárias, Leis Orçamentárias Anuais e Orçamentos Anuais do Governo do Estado, no sentido de identificar políticas voltadas ao saneamento básico para cada município. Ao efetuar o levantamento desses instrumentos para o Estado de São Paulo, constatou-se que foram elaborados os Projetos de Lei dos Planos Plurianuais referentes ao período de 1992-1995, 1996-1999 e 2000-2003. No entanto, somente o Plano Plurianual referente a 2000-2003 transformou-se em Lei (SÃO PAULO 2001a, 2001b, 2001c 2001d). Como contemplava somente o último ano da pesquisa esse instrumento foi desconsiderado.

Quanto às Leis de Diretrizes Orçamentárias do Estado de São Paulo, as prioridades e metas para cada ano não foram encontradas de forma desagregada por município, e trazem informação do tipo - ampliar de 25\% para $30 \%$ o percentual da população atendida pela coleta de esgotos nos municípios operados pela SABESP. O mesmo pode-se dizer em relação aos orçamentos anuais onde os investimentos para esses municípios não foram publicados, trazendo informação do tipo: expansão dos serviços de abastecimento de água, com obras de captação, tratamento e elevação. No que tange ao volume de recursos para o saneamento básico, os orçamentos anuais do Estado demonstram o montante para a Companhia de forma global e não explicitando qual município será beneficiado. O que é publicado é o volume de recursos do 
Tesouro do Estado destinado à SABESP. Observa-se portanto que não foi possível identificar as políticas de governo do órgão gestor dos serviços de água e esgoto nesses instrumentos.

Findadas essas apresentações, passa-se então a discorrer sobre o Município de São José dos Campos, cuja gestão dos serviços de água e esgoto é de responsabilidade da SABESP, gerenciado pela Vice-Presidência Interior e coordenado pela UN - Vale do Paraíba, a qual atende 24 municípios daquela região (SABESP 2001). Porém, antes de adentrar as questões de gestão desses serviços, são apresentadas as características gerais de São José dos Campos.

\subsubsection{São José dos Campos - gestão dos serviços de água e esgoto no âmbito do Estado}

São José dos Campos conta com uma população de 538.909 habitantes em seus $1.101 \mathrm{Km}^{2}$, sendo que 532.403 pessoas encontram-se na área urbana e 6.506 na área rural. Sua densidade demográfica é de aproximadamente 490 hab./Km² (IBGE 2002). Essa densidade é relativamente baixa quando comparada à do Município de Santo André, que é de 3708 hab. $/ \mathrm{Km}^{2}$ e com Campinas, que é de $1.217 \mathrm{hab} . / \mathrm{Km}^{2}$.

Segundo dados do SEADE (1999), a taxa geométrica de crescimento anual da população no período de $1991-2000$ foi de 2,28\% a.a.. Na tabela 20 , pode ser observada a evolução da população para o período de estudo.

Como pode ser observado na tabela 21, São José dos Campos tem uma pequena parcela da população vivendo na área rural e que vem decrescendo ao longo desses anos. 
Tabela 21. Evolução da População no Município de São José dos Campos.

\begin{tabular}{|c|c|c|c|c|c|}
\hline Ano & $\mathbf{1 9 9 6}$ & $\mathbf{1 9 9 7}$ & $\mathbf{1 9 9 8}$ & $\mathbf{1 9 9 9}$ & $\mathbf{2 0 0 0}$ \\
\hline $\begin{array}{c}\text { População } \\
\text { Total }\end{array}$ & 493.029 & 503.867 & 515.198 & 526.651 & 537.899 \\
\hline $\begin{array}{c}\text { População } \\
\text { Urbana }\end{array}$ & 481.265 & 493.293 & 505.871 & 518.639 & 531.275 \\
\hline $\begin{array}{c}\text { População } \\
\text { Rural }\end{array}$ & 11.764 & 10.574 & 9.327 & 8.012 & 6.624 \\
\hline $\begin{array}{c}\text { Taxa de } \\
\text { Urbanização }\end{array}$ & 97,61 & 97,90 & 98,19 & 98,48 & 98,77 \\
\hline
\end{tabular}

Fonte: SEADE 1999; IBGE 2000, 2001, 2002.

São José dos Campos dista $84 \mathrm{Km}$ de São Paulo (capital) e tem como municípios limítrofes: ao Norte, Camanducaia, Sapucaí Mirim-MG, ao Sul, Jacareí e Jambeiro, ao Leste, Monteiro Lobato e Caçapava e a Oeste, Igaratá, Joanópilis e Piracaia. A altitude da cidade varia entre $550 \mathrm{~m}$ a $690 \mathrm{~m}$. Em relação à temperatura, tem-se que no verão a média das temperaturas máximas é de $29,6{ }^{\circ} \mathrm{C}$ e, no inverno, a média das temperaturas mínimas é de $12^{\circ} \mathrm{C}$. O Município está inserido na Bacia Hidrográfica do Rio Paraíba do Sul e tem como afluentes o Rio Jaguari, o Rio Buquira, o Rio Comprido, o Rio Pararangaba e o Rio Alambari (PMSJC 2001).

No que tange à estruturação dos serviços de água e esgoto, pode-se dizer que o eixo central tem relações estreitas com o período conhecido como "período sanatorial", no qual foram criadas as Prefeituras Sanitárias. como conta a história. São José dos Campos foi elevada à categoria de cidade em 1864, quando era conhecida com "Vila de São José do Paraíba". Recebeu a denominação de "São José dos Campos", em 1871, em função da extensão de campinas em seu território. Já ano de 1872, cria-se a comarca. No período de 1925 a 1930, a cidade passa por uma forte epidemia de tuberculose, levando o governo federal a criar no Estado de São Paulo as Prefeituras Sanitárias. Como o clima da cidade era tido como favorável ao tratamento da dessa doença, o "município joanense é transformado em 1935 em Estância Climatérica e Estância Hidromineral, recebendo doentes de diversas localidades. Esse período ficou conhecido então como período sanatorial. Durante essa fase, a Prefeitura da Estância Climatérica e Hidromineral de São José dos Campos é gerida pelos "Prefeitos Sanitaristas" (de 1935 a 1962). A 
condição de prefeitura sanitária permanece até 1977, quando São José dos Campos recupera sua autonomia administrativa, elegendo o prefeito do município através do voto direto" (PMSJC 2001).

Por outro lado, em 1976, a prefeitura concede à SABESP a gestão dos serviços de água e esgoto do município por um período de 30 anos. Em relação ao sistema de abastecimento de água, tem-se que a população atendida atualmente com água tratada é de $100 \%$; possui 4 Estações de Tratamento de Água - ETA, variando de 4 litros por segundo a 1300 litros por segundo, e trata em média $4.500 .000 \mathrm{~m}^{3} / \mathrm{mês}$. Dessas ETAs, 3 possuem tratamento do tipo convencional e 1 com decantação, filtro lento, desinfecção e a fluoretação. Possui, também, 71 poços artesianos, sendo que o tratamento de suas águas se dá por meio de desinfecção e fluoretação.

Já em relação ao sistema de esgoto, tem-se que $99 \%$ da população são atendidos com rede. Conta com 06 Estações de Tratamento de Esgotos, variando de 04 litros por segundo a 600 litros por segundo, perfazendo um total de 674 litros por segundo de esgoto tratado. O tipo de tratamento utilizado é: lodo ativado (4 ETEs), lagoa aerada com duas lagoas facultativas (1 ETE) e decanto-digestor (1 ETE). São José dos Campos têm $42 \%$ de seus esgotos tratados.

Assim, findada a caracterização do município, passa-se neste momento à apresentação das políticas de governo da Prefeitura de São José dos Campos, voltadas ao saneamento básico - água e esgoto, as quais foram identificadas no Plano Plurianual, Leis de Diretrizes Orçamentárias, Leis Orçamentárias Anuais e Orçamentos Anuais. Desse modo, destacam-se a seguir as diretrizes identificadas nos Planos Plurianuais.

As políticas de governo identificadas para o quadriênio 1994 - 1997 podem ser observadas na tabela 22. 
Tabela 22. Projetos para 1994-1997, São José dos Campos.

Democratização do saneamento básico, estendendo a todas as parcelas da população o abastecimento de água e a coleta de esgotos.

Implantação de programas-piloto de saneamento básico, utilizando-se técnicas alternativas.

Implantação, adequação e ampliação de redes coletoras e de afastamento de esgotos (convênios e/ou contratação de obras).

Fonte: SÃO JOSÉ DOS CAMPOS 1993, 1995a, 1995b.

$\mathrm{Na}$ tabela 23 podem ser observados as políticas de governo identificadas para o quadriênio 1998 - 2001.

\section{Tabela 23. Projetos para 1998-2001, São José dos Campos.}

Implantação de rede de água e esgoto, reservatórios, emissários, estações elevatórias em vários bairros, mediante convênio com a SABESP.

Expansão do sistema de abastecimento de água e do sistema de esgoto.

Implantação e reforma das Estações de Tratamento de Esgoto.

Assistência aos bairros que não possuem rede de esgoto.

Implantação de programas-piloto de saneamento básico, utilizando-se de técnicas alternativas.

Manutenção em redes de esgoto.

Fonte: SÃO JOSÉ DOS CAMPOS 1997a, 1997c, 1998a ,1999b.

Como pode ser observado, as políticas prioritárias de governo, expressas nas diretrizes orçamentárias, período 1996 a 2000, foram: expansão do sistema de abastecimento de água e do sistema de esgoto, reforma das Estações de Tratamento de Esgoto e manutenção em redes de esgoto.

Quanto às leis orçamentárias anuais e respectivos orçamentos da prefeitura, pôde-se identificar dados quantitativos em relação à despesa do município que indiretamente demostraram a importância das questões de saneamento básico atribuídas à cidade, em cada administração. Dessa forma, apresentam-se na tabela 24 as despesas da Prefeitura de São José dos Campos e das Secretarias Municipais que têm ações voltadas ao saneamento básico no município. 
Tabela 24. Despesa da Secretaria Municipal com Programa para o Saneamento Básico.

\begin{tabular}{|c|c|c|c|c|c|}
\hline $\begin{array}{c}\text { Programa e/ou } \\
\text { Projeto }\end{array}$ & $\begin{array}{c}\text { Secretaria } \\
\text { responsável pelo } \\
\text { programa }\end{array}$ & $\begin{array}{l}\text { Orçamento da } \\
\text { Secretaria }\end{array}$ & $\begin{array}{l}\text { (\%) em } \\
\text { relação ao } \\
\text { orç. Total } \\
\text { da adm. } \\
\text { Direta }\end{array}$ & \multicolumn{2}{|c|}{$\begin{array}{c}\text { Orçamento do } \\
\text { programa e (\%) } \\
\text { em relação ao } \\
\text { orçamento da } \\
\text { Secretaria } \\
(\%) \\
\end{array}$} \\
\hline \multicolumn{6}{|c|}{ ANO 1996 - Total Geral da Administração Direta = 312.000.000,00 } \\
\hline Saneamento $\left(^{*}\right)$ & $\begin{array}{l}\text { Secretaria de Obras e } \\
\text { Habitação }\end{array}$ & 12.081.531,00 & 3,87 & $3.308 .500,00$ & 27,4 \\
\hline Saneamento $\left(^{*}\right)$ & $\begin{array}{l}\text { Secretaria de serviços } \\
\text { Municipais }\end{array}$ & $30.329 .215,00$ & 9,72 & $200.000,00$ & 0,7 \\
\hline \multicolumn{6}{|c|}{ ANO 1997 - Total Geral da Administração Direta = 314.500.000,00 } \\
\hline Saneamento $\left({ }^{*}\right)$ & $\begin{array}{l}\text { Secretaria de Obras e } \\
\text { Habitação }\end{array}$ & $16.565 .656,00$ & 5,27 & $6.357 .000,00$ & 38,3 \\
\hline \multicolumn{6}{|c|}{ ANO 1998 - Total Geral da Administração Direta $=355.200 .000,00$} \\
\hline Saneamento $\left({ }^{*}\right)$ & $\begin{array}{l}\text { Secretaria de Obras e } \\
\text { Habitação }\end{array}$ & $4.562 .657,00$ & 1,29 & $2.101 .858,00$ & 46,1 \\
\hline \multicolumn{6}{|c|}{ ANO 1999 - Total Geral da Administração Direta = 385.535.290,00 } \\
\hline Saneamento $\left({ }^{*}\right)$ & $\begin{array}{l}\text { Secretaria de Obras e } \\
\text { Habitação }\end{array}$ & $14.019 .000,00$ & 3,63 & $4.080 .244,00$ & 29,1 \\
\hline \multicolumn{6}{|c|}{ ANO 2000 - Total Geral da Administração Direta $=441.202 .000,00$} \\
\hline Saneamento $\left({ }^{*}\right)$ & $\begin{array}{l}\text { Secretaria de Obras e } \\
\text { Habitação }\end{array}$ & $11.826 .000,00$ & 2,68 & $414.000,00$ & 3,5 \\
\hline
\end{tabular}

Fonte: SÃO JOSÉ DOS CAMPOS 1996a , 1996b., 1997b ,1998a , 1999a.

${ }^{*}$ ) O programa Saneamento no orçamento incluiu: água, esgoto e drenagem.

Nota-se que a Secretaria que tem relação com o saneamento é a Secretaria de Obras e Habitação e que o percentual do volume de recursos para aqueles programas de saneamento destacados dos Planos Plurianuais e das Leis orçamentárias nos anos de 1996-1999 foi em média 35\% do valor da Secretaria. Esse percentual é bastante razoável sob o ponto de vista das diversas atribuições que tem essa Secretaria, como questões habitacionais e infra-estrutura para toda a cidade.

Dando continuidade aos procedimentos metodológicos, buscou-se identificar os resultados das políticas de governo, período 1996-2000, nas respostas do questionários aplicados na SABESP de São José dos Campos 
(UN - Vale do Paraíba), como seguem na tabela 25. Observa-se nessa tabelas que as informações não obtidas naquele órgão gestor foram levantadas em outras fontes, como o SNIS e IBGE. É importante salientar que, ao pesquisar algumas informações do SNIS e confrontá-las com as obtidas dos gestores dos serviços de água e esgoto, diversas delas revelaram-se divergentes, levando a interpretações frágeis para a sua utilização.

Tabela 25. Informações sobre Água, Esgoto e População - São José dos Campos, 1996-2000.

\begin{tabular}{|c|c|c|c|c|c|}
\hline \multirow[b]{2}{*}{ Informações } & \multicolumn{5}{|c|}{ ANO } \\
\hline & 1996 & 1997 & 1998 & 1999 & 2000 \\
\hline $\begin{array}{l}\text { População } \\
\text { urbana do } \\
\text { município } \\
\text { (hab.) }\end{array}$ & 481.265 & 493.293 & 505.871 & 518.639 & 538.909 \\
\hline $\begin{array}{l}\text { Acréscimo } \\
\text { populacional } \\
\text { urbano no ano } \\
\text { (hab.) }\end{array}$ & - & 12.028 & 12.578 & 12.678 & 20.270 \\
\hline $\begin{array}{l}\text { Acréscimo da } \\
\text { população } \\
\text { atendida com } \\
\text { água tratada no } \\
\text { período (hab.) } \\
\text { (2) }\end{array}$ & & 9.326 & 8.562 & 3.920 & 44.251 \\
\hline $\begin{array}{l}\text { Índice de } \\
\text { Atendimento de } \\
\text { Água (\%) } \\
\text { (1) }\end{array}$ & - & 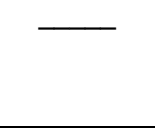 & - & 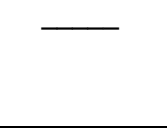 & 100 \\
\hline $\begin{array}{l}\text { Indice de } \\
\text { Hidrometração } \\
\text { (\%) (2) }\end{array}$ & L & - & 98 & 99 & - \\
\hline $\begin{array}{l}\text { Índice de } \\
\text { Perdas de } \\
\text { Faturamento } \\
\text { (\%) (2) }\end{array}$ & 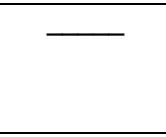 & 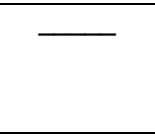 & 36 & 38 & L \\
\hline $\begin{array}{l}\text { Indice de } \\
\text { perdas Físicas } \\
(\%)\end{array}$ & - & 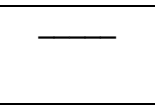 & - & 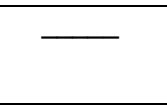 & - \\
\hline $\begin{array}{l}\text { Consumo per } \\
\text { capita } \\
\text { L /hab. dia } \\
\text { (2) }\end{array}$ & 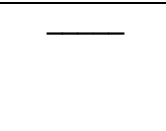 & 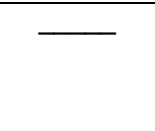 & - & - & - \\
\hline $\begin{array}{l}\text { Tarifa média } \\
\text { praticada (R\$/ } \\
\text { m3) }\end{array}$ & 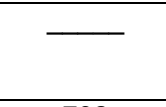 & 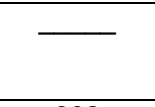 & - & - & - \\
\hline $\begin{array}{l}\text { Extensão de } \\
\text { rede de água } \\
(\mathrm{Km}) \quad(1)\end{array}$ & 792 & 802 & 824 & 853 & 871 \\
\hline $\begin{array}{l}\text { Implantação de } \\
\text { rede de água } \\
\text { no ano }(\mathrm{Km}) \\
\text { (1) }\end{array}$ & 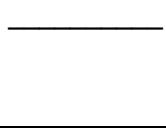 & 10 & 22 & 29 & 18 \\
\hline $\begin{array}{l}\text { Volume de } \\
\text { água tratada } \\
\text { produzido } \\
\left(\mathrm{m}^{3} / \text { ano }\right)\end{array}$ & 36.098 .500 & 50.479 .500 & 52.805 .000 & 54.972 .000 & 55.966 .000 \\
\hline $\begin{array}{l}\text { Volume de } \\
\text { água faturado } \\
\left(\mathrm{m}^{3} / \text { ano) }\right.\end{array}$ & 24.199 .500 & 33.142 .000 & 33.637 .000 & 34.360 .000 & 33.028 .000 \\
\hline
\end{tabular}




\begin{tabular}{|c|c|c|c|c|c|}
\hline $\begin{array}{l}\text { Quantidades de } \\
\text { ligações ativas } \\
\text { de água (un.) } \\
\text { (2) }\end{array}$ & 111.397 & 117.013 & 123.069 & 124.874 & 128.860 \\
\hline $\begin{array}{l}\text { Quantidade de } \\
\text { economias } \\
\text { ativas } \\
\text { micromedidas } \\
\text { (un.) (2) }\end{array}$ & 135.267 & 140.936 & 147.601 & 148.577 & 153.136 \\
\hline $\begin{array}{l}\text { Acréscimo da } \\
\text { população } \\
\text { atendida com } \\
\text { esgoto no ano } \\
\text { (hab.) (2) }\end{array}$ & & & 26.301 & 3.351 & 47.747 \\
\hline $\begin{array}{l}\text { Índice de } \\
\text { atendimento de } \\
\text { esgoto (\%) } \\
\text { (1) }\end{array}$ & & & - & ـ & 99 \\
\hline $\begin{array}{l}\text { Índice de } \\
\text { esgoto tratado } \\
(\%) \\
(1)\end{array}$ & & - & 41 & 41 & 41 \\
\hline $\begin{array}{l}\text { Extensão de } \\
\text { rede de esgoto } \\
(\mathrm{Km})(\mathbf{1})\end{array}$ & 700 & 703 & 709 & 712 & 715 \\
\hline $\begin{array}{l}\text { Implantação de } \\
\text { rede esgoto no } \\
\text { ano }(\mathrm{Km}) \quad(1)\end{array}$ & & 3 & 6 & 3 & 3 \\
\hline $\begin{array}{l}\text { Volume de } \\
\text { esgoto coletado } \\
\left(\mathrm{m}^{3} / \text { ano }\right) \quad(2)\end{array}$ & & 21.644 .500 & 22.358 .000 & 21.908 .000 & 22.199 .000 \\
\hline $\begin{array}{l}\text { Volume de } \\
\text { esgoto tratado } \\
\left(\mathrm{m}^{3} / \text { ano }\right) \quad(2)\end{array}$ & & & 9.167 .000 & 8.982 .000 & 9.102 .000 \\
\hline $\begin{array}{l}\text { Quantidades de } \\
\text { ligações de } \\
\text { esgoto (un.) (2) }\end{array}$ & & 103.774 & 109.581 & 115.351 & 118.192 \\
\hline $\begin{array}{l}\text { Quantidades de } \\
\text { economias } \\
\text { ativas de } \\
\text { esgoto (un.) (2) }\end{array}$ & & 126.574 & 132.651 & 139.229 & 142.819 \\
\hline $\begin{array}{l}\text { Receita } \\
\text { operacional dos } \\
\text { serviços de } \\
\text { água (R\$ / } \\
\text { ano) }\end{array}$ & 24.179 .176 & 27.882 .676 & 32.061 .904 & 32.899 .069 & 35.662 .926 \\
\hline $\begin{array}{l}\text { Despesa } \\
\text { operacional dos } \\
\text { serviços de } \\
\text { água ( } R \$ \text { / ano) } \\
\text { (1) }\end{array}$ & 5.273 .081 & 5.332 .007 & 5.822 .136 & 5.441 .506 & 5.161 .046 \\
\hline $\begin{array}{l}\text { Despesa + } \\
\text { custeio dos } \\
\text { serviços de } \\
\text { água }(R \$)(1) \\
\end{array}$ & 20.204 .701 & 23.296 .804 & 26.557 .494 & 26.177 .961 & 26.752 .658 \\
\hline $\begin{array}{l}\text { Investimento } \\
\text { em água } \\
\text { (R\$ / ano) (1) }\end{array}$ & 27.111 .900 & 27.049 .800 & 31.358 .600 & 28.906 .600 & 30.822 .500 \\
\hline $\begin{array}{l}\text { Receita } \\
\text { operacional dos } \\
\text { serviços de } \\
\text { esgoto } \\
\text { (R\$/ano) (1) }\end{array}$ & 16.346 .466 & 20.826 .673 & 23.350 .856 & 24.923 .333 & 27.066 .304 \\
\hline $\begin{array}{l}\text { Despesa } \\
\text { operacional dos } \\
\text { serviços de } \\
\text { esgoto }(\mathrm{R} \$ \text { / } \\
\text { ano) }\end{array}$ & 2.447 .725 & 2.118 .643 & 2.291 .213 & 2.378 .037 & 2.432 .066 \\
\hline
\end{tabular}




\begin{tabular}{|l|c|c|c|c|c|}
\hline $\begin{array}{l}\text { Despesa + } \\
\text { custeio dos } \\
\text { serviços de } \\
\text { esgoto (R\$)(1) }\end{array}$ & 10.325 .627 & 10.398 .213 & 11.454 .456 & 12.593 .064 & 13.660 .768 \\
\hline $\begin{array}{l}\text { Investimentos } \\
\text { no sistema de } \\
\text { esgoto } \\
\text { (custo + } \\
\text { investimento) } \\
\text { (1) }\end{array}$ & 29.603 .700 & 29.123 .000 & 15.592 .800 & 13.667 .600 & 15.879 .600 \\
\hline $\begin{array}{l}\text { Investimento } \\
\text { em esgoto } \\
\text { (R\$ / ano) (1) }\end{array}$ & 29.603 .700 & 29.123 .000 & 15.592 .800 & 13.667 .800 & 15.879 .600 \\
\hline $\begin{array}{l}\text { Empregados } \\
\text { próprios (2) }\end{array}$ & & & 323 & 295 & 281 \\
\hline
\end{tabular}

Fonte: (1) SABESP; (2) SNIS 1996 a 2000; (3) IBGE 2001.

Observa-se nessa tabela que as informações não obtidas naquele órgão gestor foram levantadas em outras fontes, como o SNIS e IBGE. As lacunas existentes, nessa tabela, justificam-se pela inexistência de dados no SNIS.

Findada a identificação das políticas de governo voltadas ao saneamento básico de São José dos Campos, período de 1996-2000, passa-se então a discorrer sobre o Município de Santos, cuja gestão dos serviços de água e esgoto é também de responsabilidade da SABESP, gerenciada pela Vice-Presidência Litoral e coordenada pela UN - Baixada Santista que, por sua vez, atende 9 municípios da Região Metropolitana da Baixada (SABESP 2001).

Porém, antes de adentrar as questões de gestão desses serviços, apresentam-se a seguir as características gerais de Santos.

\subsubsection{Santos - gestão dos serviços de água e esgoto no âmbito do Estado}

Santos é uma cidade litorânea que conta com uma população total de 417.777 habitantes, distribuída em seus $280 \mathrm{Km}^{2}$, sendo que 415.543 pessoas encontram-se em área urbana e $2.234 \mathrm{em}$ área rural. Tem uma densidade demográfica em torno de 1.491 hab./ $\mathrm{Km}^{2}$ e conta ainda com uma população flutuante em torno de 77.577 habitantes (IBGE 2002).

Segundo dados da SEADE (1999), a taxa geométrica de crescimento anual da população do município no período de 1991 - 2000 foi de $0,02 \%$ a.a.. Nota-se que o crescimento é bem pequeno, configurando-se como apenas o 
vegetativo. Como pode ser verificado na tabela 26 , a população vem crescendo de maneira insignificante.

Tabela 26. Evolução da População no Município de Santos.

\begin{tabular}{|c|c|c|c|c|c|}
\hline Ano & $\mathbf{1 9 9 6}$ & $\mathbf{1 9 9 7}$ & $\mathbf{1 9 9 8}$ & $\mathbf{1 9 9 9}$ & $\mathbf{2 0 0 0}$ \\
\hline $\begin{array}{c}\text { População } \\
\text { Total }\end{array}$ & 417.479 & 417.552 & 417.625 & 417.698 & 417.771 \\
\hline $\begin{array}{c}\text { População } \\
\text { Urbana }\end{array}$ & 415.579 & 415.570 & 415.561 & 415.553 & 415.543 \\
\hline $\begin{array}{c}\text { População } \\
\text { rural }\end{array}$ & 1.900 & 1.982 & 2.064 & 2.145 & 2.234 \\
\hline $\begin{array}{c}\text { Taxa de } \\
\text { Urbanização }\end{array}$ & 99,54 & 99,53 & 99,51 & 99,49 & 99,47 \\
\hline
\end{tabular}

Fonte: SEADE 1999; IBGE 2000, 2001, 2002.

Santos dista $72 \mathrm{Km}$ de São Paulo (capital) e está inserida na Região Metropolitana da Baixada Santista, formada por 9 cidades e composta por 1,3 milhões de habitantes. Essa Região foi criada em 30 de julho de 1993, através da Lei Complementar nº 815/96. Os municípios que a compõem são: Bertioga, Cubatão, Guarujá, Itanhaém, Mongaguá, Peruíbe, Praia Grande, Santos e São Vicente. A busca de soluções, por parte dos prefeitos, para os problemas comuns dessas cidades culminou com a criação, no âmbito do município de Santos, da Secretaria de Assuntos Metropolitanos. Fruto desse movimento é a criação da Região Metropolitana que conta com um Conselho de Desenvolvimento da Baixada Santista - Condesb, deliberativo, parte integrante da Agência Metropolitana da Baixada Santista - AGEM, autarquia, criada em 1998. Essa Agência tem por finalidade integrar a organização, o planejamento e a execução das funções públicas de interesse comum na Região Metropolitana da Baixada Santista, e é vinculada à Secretaria dos Transportes Metropolitanos. Como o Condesb foi formado somente de prefeitos e de representantes do governo estadual, houve um movimento por parte de vereadores reivindicando tal composição, criando então a Câmara Comum Metropolitana da Baixada Santista, em julho de 1999 (SANTOS 2001b).

Nota-se que a Região Metropolitana da Baixada Santista tem diversas instâncias de discussão dos problemas existentes em suas cidades, ficando portanto o desafio de articulá-las e integrá-las para as tomadas de decisão. 
No que diz respeito à estruturação da gestão dos serviços de água e esgoto pode-se dizer que, quando a cidade de Santos foi criada, em 1839, encontrava-se bastante movimentada por ser uma cidade portuária recebendo embarcações de diversos países. As condições sanitárias eram precárias, levando à ocorrência de diversas epidemias de doenças, como a peste bubônica, febre amarela, tifo e malária, dentre outras, fatos esses marcados por longos anos (antes de 1890 até 1905). Criaram-se nessa ocasião diversas comissões e repartições públicas, visando sanear a região, culminando em 1897 com a outorga, por parte do Governo do Estado de São Paulo, dos serviços de abastecimento de água da cidade de Santos e seus arredores à The City of Santos Improvements Co. Ltda., a responsabilidade pelos serviços de abastecimento de água da cidade de Santos e seus arredores em 1897. Em 1902, nasce a Comissão de Saneamento de Santos com a responsabilidade de cuidar dos serviços de construção e conservação da rede de esgotos da cidade de Santos e da fiscalização do serviço de abastecimento de água da The City of Santos Improvements Co.Ltda.. Em 1915, é extinta a Comissão de Saneamento de Santos, dando lugar à Repartição de Saneamento de Santos, subordinada à Secretária da Agricultura do Estado de São Paulo até maio de 1929. Em janeiro de 1950, é criado o Departamento de Obras Sanitárias, sob responsabilidade da Secretária de Viação e Obras Públicas, assumindo o patrimônio da Repartição de Saneamento de Santos. Nesse mesmo ano, os serviços de água e esgoto de Guarujá também ficam subordinados ao Departamento de Obras Sanitárias. Já em 1951, a Repartição de Saneamento de Santos volta a existir, tendo como atribuições, os estudos, projetos, fiscalização, construção, conservação e operacionalização dos sistemas de abastecimento de água, dos sistemas de esgoto sanitários, dos sistemas de drenagem, sistemas de coleta, transporte e disposição de lixo. Em 1953, é constituído o Serviço de Água de Santos e Cubatão, também subordinados ao Departamento de Obras Sanitárias. É criada em novembro de 1968 a Superintendência de Saneamento da Baixada Santista. Após um ano da existência da Superintendência de Saneamento da Baixada Santista, nasce a Companhia de Saneamento Básico da Baixada Santista, responsável pelos 
serviços de água e esgoto dos municípios de Santos, Guarujá, Cubatão, São Vicente e Praia Grande (SANTOS s.d.p.).

De forma gradativa a Companhia de Saneamento Básico da Baixada Santista vai tendo a concessão dos serviços de água e esgoto de outros municípios como: Mongaguá, Ilha Bela, Ubatuba, São Sebastião e Caraguatatuba, sendo repassados à concessionária os bens, diretos e obrigações dos municípios concedentes. Nasce em 1973 a Companhia de Saneamento Básico do Estado de São Paulo - SABESP, tendo como atribuições planejar, executar e operar os serviços de saneamento básico em todo o território do Estado de São Paulo, e que no ano de 1975 incorpora a Companhia da Baixada Santista (SANTOS s.d.p.).

No que concerne ao sistema de abastecimento de água, Santos conta atualmente com $100 \%$ da população abastecida com água tratada, a qual é importada da Estação de Tratamento de Água de Cubatão, pois o Sistema é Integrado com outros municípios. Em relação ao sistema de esgotos, apresenta-se com $95 \%$ dos seus esgotos coletados e tratados. O restante $(5 \%)$ sem tratamento é referente a loteamentos clandestinos, favelas e demais tipos de moradia considerado ilegal para que a Companhia de Saneamento proporcione infra-estrutura. Conta com uma Estação de Tratamento de Esgoto, com capacidade para tratar 2.000 litros/segundo. A Estação de Tratamento é de pré-condicionamento com disposição oceânica.

Assim, concluída a caracterização do município, passa-se neste momento à apresentação das políticas de governo da Prefeitura de Santos período de 1996-2000, voltadas ao saneamento básico - água e esgoto - as quais foram identificadas no Plano Plurianual, Leis de Diretrizes Orçamentárias, Leis Orçamentárias Anuais e Orçamentos Anuais. Desse modo, destacam-se a seguir as diretrizes identificadas nos Planos Plurianuais.

No Plano Plurianual, quadriênio 1994 a 1997, pôde-se identificar os seguintes programas para os serviços de água e esgoto: Municipalização do saneamento e Obras de esgotamento sanitário nos morros de Santos 
(SANTOS 1993). É importante destacar que para este quadriênio não foram detalhados os objetivos de cada programa, apresentando-se de forma bem geral. Já para o quadriênio 1998 a 2001, pôde-se identificar as metas e objetivos para os serviços de água e esgoto, conforme mostra a tabela 27.

Tabela 27. Metas e Objetivos do Plurianual para 1998 - 2001, Santos.

\begin{tabular}{|l|l|l|}
\hline \multicolumn{2}{|c|}{ METAS } & \multicolumn{1}{|c|}{ OBJETIVOS } \\
\hline Municipalização do saneamento básico & $\begin{array}{l}\text { Controle das ações do saneamento } \\
\text { básico no âmbito municipal }\end{array}$ \\
\hline $\begin{array}{l}\text { Redes emergenciais de afastamento de } \\
\text { esgoto }\end{array}$ & $\begin{array}{l}\text { Melhoria da qualidade de vida da } \\
\text { população dos morros e diminuição do } \\
\text { risco geológico }\end{array}$ \\
\hline $\begin{array}{l}\text { Implantação do sistema de captação, } \\
\text { tratamento de esgotos na Área } \\
\text { Continental }\end{array}$ & $\begin{array}{l}\text { Dotar a área continental de } \\
\text { saneamento básico necessário ao seu } \\
\text { desenvolvimento }\end{array}$ \\
\hline $\begin{array}{l}\text { Detecção e identificação de ligações } \\
\text { clandestinas de esgoto }\end{array}$ & $\begin{array}{l}\text { letectar e corrigir no sistema de } \\
\text { drenagem do município as ligações } \\
\text { clandestinas de esgoto }\end{array}$ \\
\hline
\end{tabular}

Fonte: SANTOS 1997a.

De acordo com (SANTOS 1996a, 1996c, 1997c, 1998c, 1999b) nas diretrizes orçamentárias para o período do 1996 a 2000, pôde-se depreender das seguintes metas e prioridades: Implantação de rede coletora de esgotos na zona noroeste e nos morros; Implantação de programas de identificação de ligações clandestinas de esgoto; Municipalização do saneamento; Ações de coordenação junto às secretarias municipais em atividades relacionadas ao saneamento básico na Baixada Santista; Universalização do saneamento; Coordenar as ações municipais relativas à implantação de infra-estrutura de água e esgoto; Implantação de mini-estações de tratamento de água das bicas; Desenvolver projetos para implantação de tratamento de esgotos em áreas não atingidas pela SABESP; Instalação, ampliação e manutenção de redes coletoras de esgotos.

Portanto, as políticas de governo refletidas nas diretrizes orçamentárias e nos planos plurianuais foram: municipalização e universalização do saneamento; expansão e manutenção de redes coletoras na zona noroeste e nos morros; implantação do sistema de coleta e tratamento de esgotos na área 
continental de Santos; e desenvolvimento de projetos para implantação de tratamento de esgotos em áreas não atingidas pela SABESP.

Quanto às leis orçamentárias anuais e respectivos orçamentos da prefeitura, pôde-se identificar dados quantitativos em relação à despesa do município que indiretamente demostraram a importância das questões de saneamento básico atribuídas à cidade, em cada administração. Dessa forma, apresentam-se na tabela 28 as despesas da Prefeitura de Santos e das Secretarias Municipais que têm ações voltadas ao saneamento básico no município. 
Tabela 28. Despesa das Secretarias Municipais com Programas de Saneamento Básico, Santos.

\begin{tabular}{|c|c|c|c|c|c|}
\hline $\begin{array}{c}\text { Programa e/ou } \\
\text { Projeto }\end{array}$ & $\begin{array}{c}\text { Secretaria } \\
\text { responsável } \\
\text { pelo programa }\end{array}$ & $\begin{array}{l}\text { Orçamento da } \\
\text { Secretaria }\end{array}$ & $\begin{array}{l}\text { (\%) em relação } \\
\text { ao orçamento } \\
\text { total da } \\
\text { administração } \\
\text { direta }\end{array}$ & $\begin{array}{r}\text { Orçamer } \\
\text { program } \\
\text { em relaç } \\
\text { orçamer } \\
\text { Secret } \\
(\%) \\
\end{array}$ & $\begin{array}{l}\text { to do } \\
\text { e (\%) } \\
\text { ao ao } \\
\text { to da } \\
\text { aria } \\
\end{array}$ \\
\hline ANO 1996 - Total & Geral da Adminis & ação Direta $=265$ & $5.000 .000,00$ & & \\
\hline $\begin{array}{l}\text { Municipalização } \\
\text { do saneamento }\end{array}$ & $\begin{array}{l}\text { Secretaria do Meio } \\
\text { Ambiente }\end{array}$ & $33.900 .600,00$ & 12,7927 & 1000,00 & 0,0030 \\
\hline $\begin{array}{l}\text { Implantação de } \\
\text { rede coletora de } \\
\text { esgoto nos } \\
\text { morros de Santos } \\
\end{array}$ & $\begin{array}{l}\text { Administração } \\
\text { Regional dos } \\
\text { Morros }\end{array}$ & $2.293 .590,00$ & 0,8655 & $65.000,00$ & 2,8333 \\
\hline ANO 1997 - Total & Geral da Adminis & ação Direta $=35$ & $4.000 .000,00$ & & \\
\hline $\begin{array}{l}\text { Municipalização } \\
\text { do saneamento }\end{array}$ & $\begin{array}{l}\text { Secretaria do Meio } \\
\text { Ambiente }\end{array}$ & $50.580 .450,00$ & 14,2883 & $10.000,00$ & 0,0198 \\
\hline $\begin{array}{l}\text { Implantação de } \\
\text { rede coletora de } \\
\text { esgoto nos } \\
\text { morros de Santos }\end{array}$ & $\begin{array}{l}\text { Administração } \\
\text { Regional dos } \\
\text { Morros }\end{array}$ & $3.667 .350,46$ & 1,0360 & $66.300,00$ & 1,8078 \\
\hline ANO 1998 - Total & Geral da Adminis & ação Direta $=403$ & $3.000 .000,00$ & & \\
\hline $\begin{array}{l}\text { Municipalização } \\
\text { do saneamento }\end{array}$ & $\begin{array}{l}\text { Secretaria do Meio } \\
\text { Ambiente }\end{array}$ & $44.952 .653,55$ & 11,1545 & $10.000,00$ & (0,0222 \\
\hline $\begin{array}{l}\text { Implantação de } \\
\text { rede coletora de } \\
\text { esgoto nos } \\
\text { morros de Santos }\end{array}$ & $\begin{array}{l}\text { Administração } \\
\text { Regional dos } \\
\text { Morros }\end{array}$ & $4.016 .916,94$ & 0,9968 & $80.000,00$ & 1,9916 \\
\hline ANO 1999 - Total & Geral da Adminis & ação Direta $=410$ & $0.000 .000,00$ & & \\
\hline $\begin{array}{l}\text { Municipalização } \\
\text { do saneamento } \\
\text { Implantação de } \\
\text { rede coletora de } \\
\text { esgoto nos } \\
\text { morros de Santos }\end{array}$ & $\begin{array}{l}\text { Secretaria do } \\
\text { Desenvolvimento } \\
\text { Urbano e } \\
\text { Ambiental }\end{array}$ & $75.791 .575,35$ & 18,4856 & $500.000,00$ & 0,6597 \\
\hline $\begin{array}{l}\text { morros de Santos } \\
\text { Identificação de } \\
\text { ligações } \\
\text { clandestinas de } \\
\text { esgotos }\end{array}$ & & & & $\begin{array}{r}20.000,00 \\
200.000,00\end{array}$ & $\begin{array}{r}0,02638 \\
0,2638\end{array}$ \\
\hline ANO 2000 - Total & Geral da Adminis & ção Direta $=41 \mathrm{c}$ & $0.000 .000,00$ & & \\
\hline $\begin{array}{l}\text { Municipalização } \\
\text { do saneamento } \\
\text { Identificação de } \\
\text { ligações } \\
\text { clandestinas de } \\
\text { esgotos }\end{array}$ & $\begin{array}{l}\text { Secretaria do } \\
\text { Desenvolvimento } \\
\text { Urbano e } \\
\text { Ambiental }\end{array}$ & $76.578 .655,43$ & 18,6778 & $\begin{array}{r}60.000,00 \\
350.000,00\end{array}$ & $\begin{array}{l}0,0784 \\
0,4571\end{array}$ \\
\hline
\end{tabular}

Fonte: SANTOS 1995 a 1999.

Observa-se nessa tabela 28 que as Secretarias responsáveis pela implementação daqueles programas identificados nos Planos Plurianuais, Leis de Diretrizes Orçamentárias são as Secretarias Municipais de Meio Ambiente e Administração dos Morros que posteriormente ficaram a cargo da Secretaria do 
Desenvolvimento Urbano e Ambiental. Nota-se ainda que o programa Municipalização do Saneamento, aparece em todos ao anos nos orçamentos, indicando que é um desejo da Prefeitura.

Quanto ao programa de implantação de rede coletora de esgotos nos Morros de Santos, observa-se quão baixos são os percentuais do volume de recursos direcionados à Secretaria responsável pela execução (em torno de $1 \%$ do orçamento da Prefeitura).

Dando prosseguimento aos procedimentos metodológicos, buscou-se identificar os resultados das políticas de governo voltadas ao saneamento básico água e esgoto - período 1996-2000, nas respostas do questionários aplicados na SABESP de Santos (UN - Litoral). Esses resultados apresentamse na tabela 29. 
Tabela 29.Informações sobre Água, Esgoto e População de Santos, 1996-2000.

\begin{tabular}{|c|c|c|c|c|c|}
\hline \multirow{2}{*}{ Informações } & \multicolumn{5}{|c|}{ ANO } \\
\hline & 1996 & 1997 & 1998 & 1999 & 2000 \\
\hline $\begin{array}{l}\text { População } \\
\text { urbana do } \\
\text { município (hab.) } \\
\text { (3) }\end{array}$ & 415.579 & 415.570 & 415.561 & 415.553 & 415.543 \\
\hline $\begin{array}{l}\text { Acréscimo } \\
\text { populacional } \\
\text { urbano no ano } \\
\text { (hab.) }\end{array}$ & & -9 & -9 & -8 & -10 \\
\hline $\begin{array}{l}\text { Indice de } \\
\text { Atendimento de } \\
\text { Água (\%) } \\
\text { (1) }\end{array}$ & 100 & 100 & 100 & 100 & 100 \\
\hline $\begin{array}{l}\text { Indice de } \\
\text { Hidrometração } \\
(\%) \\
(2)\end{array}$ & & & 99,8 & 99,8 & 100 \\
\hline $\begin{array}{l}\text { Indice de Perdas } \\
\text { de Faturamento } \\
(\%)\end{array}$ & & & - & 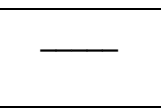 & - \\
\hline $\begin{array}{l}\text { Consumo } \\
\text { percapita } \\
\text { l/hab./dia } \\
\text { (2) }\end{array}$ & & 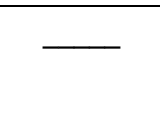 & 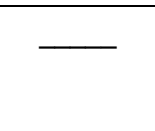 & 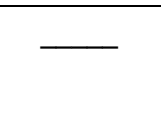 & 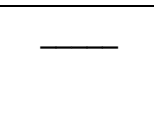 \\
\hline $\begin{array}{l}\text { Tarifa Média } \\
\text { Praticada }\left(\mathrm{R} \$ / \mathrm{m}^{3}\right) \\
\text { (2) }\end{array}$ & & & & 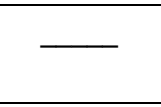 & 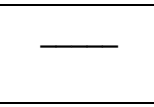 \\
\hline $\begin{array}{l}\text { Extensão de rede } \\
\text { de água }(\mathrm{Km}) \\
\text { (1) }\end{array}$ & 982 & 984 & 986 & 988 & 988 \\
\hline $\begin{array}{l}\text { Implantação de } \\
\text { rede de água no } \\
\text { ano } \\
\text { (1) }\end{array}$ & & 2,7 & 1,3 & 1,8 & 0 \\
\hline $\begin{array}{l}\text { Volume de água } \\
\text { tratada produzido } \\
\left(\mathrm{m}^{3} / \mathrm{ano}\right)(\mathbf{1})\end{array}$ & 75.217 .000 & 76.488 .000 & 68.171 .000 & 79.237 .000 & 79.075 .000 \\
\hline $\begin{array}{l}\text { Volume de água } \\
\text { faturado }\left(\mathrm{m}^{3} /\right. \\
\text { ano) (2) }\end{array}$ & 31.901 .000 & 42.413 .000 & 44.401 .000 & 41.106 .000 & 41.250 .000 \\
\hline $\begin{array}{l}\text { Quantidades de } \\
\text { ligações ativas de } \\
\text { água (un.) (2) }\end{array}$ & 58.508 & 59.239 & 58.508 & 59.384 & 60.001 \\
\hline $\begin{array}{l}\text { Quantidade de } \\
\text { economias de } \\
\text { água ativas } \\
\text { micromedidas } \\
\text { (un.) (2) }\end{array}$ & 176.580 & 178.323 & 179.575 & 174.431 & 175.971 \\
\hline $\begin{array}{l}\text { População } \\
\text { atendida com } \\
\text { rede de esgoto } \\
\text { (2) }\end{array}$ & 382.839 & 381.593 & 386.515 & 384.370 & 394.766 \\
\hline $\begin{array}{l}\text { Acréscimo da } \\
\text { população } \\
\text { atendida com } \\
\text { esgoto no ano } \\
\text { (hab.) (2) }\end{array}$ & & -1246 & 4922 & -2145 & 10.396 \\
\hline $\begin{array}{l}\text { Índice de } \\
\text { Atendimento de } \\
\text { Esgoto (\%) } \\
\text { (1) }\end{array}$ & 91 & 93 & 94 & 95 & 95 \\
\hline
\end{tabular}




\begin{tabular}{|c|c|c|c|c|c|}
\hline $\begin{array}{l}\text { Índice de Esgoto } \\
\text { Tratado (\%) } \\
\text { (1) }\end{array}$ & 91 & 93 & 94 & 95 & 95 \\
\hline $\begin{array}{l}\text { Extensão de rede } \\
\text { de esgoto }(\mathrm{Km})\end{array}$ & 342,9 & 342,9 & 342,9 & 343,5 & 343,5 \\
\hline $\begin{array}{l}\text { Implantação de } \\
\text { rede esgoto no } \\
\text { ano }(\mathrm{Km})(\mathbf{1})\end{array}$ & 0 & 0 & 0 & 0,6 & 0 \\
\hline $\begin{array}{l}\text { Volume de } \\
\text { esgoto coletado } \\
\text { ( } \mathrm{m}^{3} / \text { ano) } \\
\text { (1) }\end{array}$ & 28.537 .000 & 29.032 .000 & 30.170 .000 & 28.156 .000 & 28.332 .000 \\
\hline $\begin{array}{l}\text { Volume de } \\
\text { esgoto tratado } \\
\left(\mathrm{m}^{3} / \text { ano) (1) }\right.\end{array}$ & 28.537 .000 & 29.032 .000 & 30.170 .000 & 28.156 .000 & 28.332 .000 \\
\hline $\begin{array}{l}\text { Quantidades de } \\
\text { ligações de } \\
\text { esgoto (un.) } \\
\text { (2) }\end{array}$ & 47.165 & 48.704 & 50.180 & 50.597 & 51.253 \\
\hline $\begin{array}{l}\text { Quantidades de } \\
\text { economias ativas } \\
\text { de esgoto (un.) } \\
\text { (2) }\end{array}$ & 162.874 & 165.704 & 168.438 & 163.693 & 165.469 \\
\hline $\begin{array}{l}\text { Receita } \\
\text { operacional dos } \\
\text { serviços de água } \\
\text { (R\$ / ano) } \\
\text { (2) }\end{array}$ & 39.690 .779 & 50.538 .200 & 448.634 .119 & 46.057 .699 & 49.894 .280 \\
\hline $\begin{array}{l}\text { Receita } \\
\text { operacional dos } \\
\text { serviços de } \\
\text { esgoto (R\$/ano) } \\
\text { (2) }\end{array}$ & 32.525 .445 & 37.176 .701 & 41.035 .571 & 40.881 .431 & 44.297 .484 \\
\hline $\begin{array}{l}\text { Despesa } \\
\text { operacional dos } \\
\text { serviços de } \\
\text { esgoto ( } R \$ \text { / ano) } \\
\text { (2) }\end{array}$ & & 5.471 .913 & 3.060 .817 & 1.703 .319 & 5.085 .349 \\
\hline $\begin{array}{l}\text { Despesa } \\
\text { operacional dos } \\
\text { serviços de água } \\
\text { (R\$ / ano) } \\
\text { (2) }\end{array}$ & & 3.961 .406 & 1.575 .079 & 1.482 .807 & 1.249 .787 \\
\hline $\begin{array}{l}\text { Investimento em } \\
\text { esgoto } \\
\text { (R\$ / ano) (2) }\end{array}$ & & 5.471 .913 & 3.060 .817 & 1.703 .319 & 5.085 .349 \\
\hline $\begin{array}{l}\text { Investimento em } \\
\text { água } \\
\text { (R\$ / ano) (2) }\end{array}$ & & 3.961 .406 & 1.575 .079 & 1.482 .807 & 1.246 .787 \\
\hline $\begin{array}{l}\text { Investimento } \\
\text { disponível } \\
\text { apontado no } \\
\text { orçamento anual } \\
\text { (R\$) }\end{array}$ & & & & & \\
\hline $\begin{array}{l}\text { Empregados } \\
\text { próprios (1) }\end{array}$ & & 281 & 295 & 667 & 651 \\
\hline $\begin{array}{l}\text { Investimentos em } \\
\text { capacitação de } \\
\text { pessoal } \\
\text { (R\$ / ano) (1) }\end{array}$ & $102.177,8$ & $131.194,2$ & $93.738,3$ & $46.734,1$ & $62.799,6$ \\
\hline
\end{tabular}

Fonte: (1) SABESP; (2) SNIS 1996 a 2000; (3) IBGE 2000.

Observa-se nessa tabela que as informações não obtidas naquele órgão gestor foram levantadas em outras fontes como o SNIS e IBGE. As lacunas existentes, nessa tabela, justificam-se pela inexistência também de 
informações no SNIS. É importante salientar que, ao pesquisar algumas informações do SNIS e confrontá-las com as obtidas dos gestores dos serviços de água e esgoto, diversas delas revelaram-se divergentes, levando a interpretações frágeis para a sua utilização.

Assim, foram identificadas as políticas de governo para o saneamento básico - água e esgoto, no Município de Santos para o período de 1996 2000.

Como se vê, neste item 4, apresentaram-se os Resultados da Pesquisa em relação à identificação das políticas públicas nacional, estadual e municipais, relacionadas num primeiro momento ao saneamento básico e num segundo momento aos serviços de água e esgoto. Tais políticas foram identificadas nas diretrizes contidas nos artigos da Constituição Federal de 1988, Política Nacional de Meio Ambiente, instituída pela Lei 6.938 , de 31/08/1981, Política Nacional de Saúde, instituída pela Lei 8.080 , de 19/09/1990, e a Política Nacional de Recursos Hídricos, instituída pela Lei 9.433, de 08/01/1997, na Constituição do Estado de São Paulo 1989, na Política de Saneamento do Estado São Paulo, instituída pela Lei 7.750 , de 31/03/1992, na Política de Recursos Hídricos do Estado de São Paulo, instituída pela Lei 7.663, de 30/12/1991, e, finalmente, nas Leis Orgânicas Municipais e nos Planos Diretores dos quatro municípios.

As diretrizes identificadas nessas leis foram tomadas como parâmetros para analisar as diferenças na eficiência e na eficácia da gestão municipal e estadual dos serviços de água e esgoto.

Esse item apresentou ainda as políticas de governo voltadas ao saneamento básico - água e esgoto - nos Municípios de Campinas, Santo André, São José dos Campos e Santos, no período de 1996 a 2000, caracterizando-as no contexto desse trabalho.

Tais políticas de governo foram identificadas nos órgãos gestores das prefeituras, bem como nos órgãos gestores dos serviços de água e esgoto. Para tanto, foram utilizados os seguintes instrumentos tomados como 
parâmetros para analisar diferenças na eficiência e eficácia da gestão municipal e estadual: Planos Plurianuais, Leis de Diretrizes Orçamentárias, Leis Orçamentárias Anuais, Orçamentos Anuais, Planejamento Estratégicos e os resultados dos questionários respondidos. Dessa forma, a comparação desses parâmetros de políticas publicas com parâmetros de políticas de governo possibilitou a discussão sobre as diferenças na eficiência e na eficácia da gestão com comando municipal e estadual desses serviços, conforme segue. 


\section{Discussão dos Resultados}

\footnotetext{
"Todo ponto de vista é a vista de um ponto. Para entender como alguém lê, é necessário saber como são seus olhos e qual é sua visão de mundo" (Leonardo Boff).
}

Neste item serão discutidos e analisados os resultados da pesquisa ora apresentados. Assim, os parâmetros para análise da gestão municipal e estadual dos serviços de água e esgoto foram as políticas públicas e políticas de governo, conforme já apresentados no item 3. Assim sendo, para analisar a eficiência na gestão municipal e estadual desses serviços, nos municípios de Campinas, Santo André, São José dos Campos e Santos, foram destacadas as diretrizes contidas nos artigos das leis orgânicas e dos planos diretores, cruzando-as com programas, projetos, atividades, obras e metas estabelecidas nos Planos Plurianuais, Leis de Diretrizes Orçamentárias, Orçamentos Anuais e Planejamentos Estratégicos. Quanto à análise na eficácia da gestão municipal e estadual, foram tomados como parâmetros os resultados qualitativos e quantitativos obtidos via questionários e pesquisa documental, cruzando-os com as diretrizes destacadas nos artigos das leis orgânicas e dos planos diretores e com os programas, projetos, atividades, obras e metas estabelecidas nos Planos Plurianuais, Leis de Diretrizes Orçamentárias, Orçamentos Anuais e Planejamentos Estratégicos. Assim, foram destacados os aspectos de água e esgoto de cada município e tomados como parâmetros de conclusões sobre diferenças na eficiência e na eficácia da gestão municipal e estadual. Desse modo, apresentam-se na seqüência os Municípios de Campinas, Santo André, São José dos Campos e Santos.

\section{- Campinas}

Na Lei Orgânica de Campinas, um ponto a ser destacado é o fato de deixar bem clara a priorização quanto à forma de organização e prestação dos serviços públicos, sendo que prioritariamente será por outorga às suas autarquias ou entidades paraestatais e, em seguida, por delegação a particulares, mediante concessão, permissão ou autorização, nos dois casos podendo ser centralizada ou descentralizada. 
Esta amarração na lei orgânica sobre a forma de prestação dos serviços públicos é um fator favorável para o município, na medida em que o setor privado vem de maneira gradativa atuando nos serviços de natureza pública.

O artigo 5 da Lei Orgânica diz respeito ao controle da poluição e à proteção ao meio ambiente e o artigo 8 coloca que o município assegurará recursos para, no prazo de 10 anos da promulgação da lei orgânica de 1990, promover o tratamento de todo esgoto da cidade. Pois bem, comparando isso com os resultados identificados nas políticas de governos, Campinas apresenta uma evolução no índice de tratamento muito insignificante perante o volume de esgoto coletado, como pode ser observado na tabela 30 a seguir.

Ao destacar as diretrizes contidas na Lei Orgânica e no Plano Diretor de Campinas, e cruzando-as com os programas, projetos, atividades, obras e metas, das políticas de governo do município, puderam ser identificados pontos na eficiência e na eficácia da gestão em relação aos aspectos de esgoto e de água, conforme apresentados nas tabelas 30 e 31 . 
Tabela 30. CAMPINAS - Aspecto Esgoto.

LeI ORgÂnica e Plano Diretor X PRogramas e Projetos X Resultados

Pop. Urbana em 1996: 891.670 hab.

Pop. Urbana em 2000: 950.533 hab.

\begin{tabular}{|c|c|c|}
\hline $\begin{array}{c}\text { DIRETRIZES DA LEI ORGÂNICA } \\
\text { de } 1990\end{array}$ & $\begin{array}{l}\text { PROGRAMAS / PROJETOS / ATIVIDADES / OBRAS } \\
\text { IDENTIFICADAS NAS POLÍTICAS DE GOVERNO } \\
\text { MUNICIPAL PARA O PERÍODO } 1996 \text { - } 2000\end{array}$ & $\begin{array}{c}\text { RESULTADOS DAS POLÍTICAS DOS } \\
\text { GOVERNOS DO ÓRGÃO GESTOR DOS } \\
\text { SERVIÇOS } \\
\text { PERIOODO } 1996 \text { a } 2000\end{array}$ \\
\hline $\begin{array}{l}\text { O Município assegurará, anualmente, recursos } \\
\text { necessários, para no prazo de } 10 \text { anos, a partir } \\
\text { da promulgação desta lei, promover o } \\
\text { tratamento de todo o esgoto da cidade (art. 8). } \\
\text { Compete ao Município, concorrentemente com a } \\
\text { União e o Estado, proteger o meio ambiente e } \\
\text { combater a poluição em qualquer de suas } \\
\text { formas (artigo } 5 \text {, inciso VI). } \\
\text { Acesso universal e igualitário de todos os } \\
\text { munícipes às ações e serviços de promoção, } \\
\text { proteção e recuperação da saúde, sem qualquer } \\
\text { discriminação (art. } 205 \text {, incisos I e II). }\end{array}$ & $\begin{array}{l}\text { Tratamento de Esgoto da Microbacia de Barão Geraldo e das } \\
\text { Sub-bacias Samambaia e Costa e Silva. } \\
\text { Despoluição da Lagoa do Taquaral. } \\
\text { Estação de Tratamento de Esgoto Costa e Silva. } \\
\text { Interceptação e bombeamento. } \\
\text { Coleta de esgoto em bairros e favelas. } \\
\text { Tratamento de esgoto da bacia do Rio Atibaia, do Rio Quilombo e } \\
\text { do Rio Capivari (Mananciais da cidade). } \\
\text { Saneamento da Bacia do Anhumas. }\end{array}$ & $\begin{array}{l}\text { Índice de atendimento de esgoto passou de } 86 \text { a } \\
88,0 \% \text {. } \\
\text { Índice de esgoto tratado passou de } 1,7 \% \text { para } \\
5,6 \% \text {. } \\
\text { Volume de esgoto tratado passou de } 66.786 .758 \\
\text { m3/ano para } 51.694 .874 \text { m3/ano. } \\
\text { Investimento de esgoto passou de } \mathrm{R} \$ \\
14.182 .318,00 \text { para } R \$ 4.662 .356,00 \text {. } \\
\text { Quantidade de economias ativas passou de } \\
263.763 \text { para } 298.342 \text {. } \\
\text { Recuperação de perdas de faturamento com } \\
\text { atuação em ligações clandestinas de esgotos, da } \\
\text { ordem de } 70 \% \text {. } \\
\text { Redução do tempo médio de atendimento à } \\
\text { ligaçóes de esgoto: de } 70 \text { dias para } 16 \text { dias. } \\
\text { Obrigatoriedade de tratamento de esgotos para } \\
\text { novos empreendimentos. (projeto de lei aprovado } \\
\text { na Câmara Municipal). }\end{array}$ \\
\hline DIRETRIZES PLANO DIRETOR & $\begin{array}{c}\text { PROGRAMAS / PROJETOS / ATIVIDADES / METAS E OBRAS } \\
\text { IDENTIFICADAS NAS POLÍTICAS DE GOVERNO MUNICIPAL } \\
\text { PARA O PERÍODO } 1996-2000\end{array}$ & $\begin{array}{c}\text { RESULTADOS DE POLÍTICAS DE GOVERNO DO } \\
\text { ÓRGÃO GESTOR DOS SERVIÇOS } \\
\text { PERÍODO } 1996 \text { a } 2000\end{array}$ \\
\hline $\begin{array}{l}\text { Definir critérios de cobrança das despesas com } \\
\text { a prestação dos serviços de esgotamento } \\
\text { sanitário mediante a imposição de tarifas e taxas } \\
\text { diferenciadas observados os aspectos } \\
\text { técnicos, custos, a destinação social dos } \\
\text { serviços e o poder aquisitivo da população } \\
\text { beneficiada. }\end{array}$ & $\begin{array}{l}\text { Não foi encontrado de forma explícita um programa para a } \\
\text { discussão do sistema tarifário porém, foram encontradas as } \\
\text { tarifas dos serviços. }\end{array}$ & $\begin{array}{l}\text { Há tarifas diferenciadas classificadas em } \\
\text { residencial padrão, residencial social, residencial } \\
\text { com ligação coletiva, residencial com pequeno } \\
\text { comércio, comercial, comercial em núcleos não } \\
\text { urbanizados e pública }\end{array}$ \\
\hline
\end{tabular}


Tabela 31. CAMPINAS - Aspecto Água.

\section{Lei Orgânica e Plano Diretor X Programas e Projetos X Resultados}

\begin{tabular}{|c|c|c|}
\hline $\begin{array}{c}\text { DIRETRIZES DA LEI ORGÂNICA } \\
\text { de } 1990\end{array}$ & $\begin{array}{c}\text { PROGRAMAS / PROJETOS / ATIVIDADES / OBRAS } \\
\text { IDENTIFICADAS NAS POLÍTICAS DE GOVERNO MUNICIPAL } \\
\text { PARA O PERÍODO } 1996-2000\end{array}$ & $\begin{array}{c}\text { RESULTADOS DE POLÍTICAS DE GOVERNO DO } \\
\text { ÓRGÃO GESTOR DOS SERVIÇOS } \\
\text { PERÍODO } 1996 \text { A } 2000\end{array}$ \\
\hline $\begin{array}{l}\text { Acesso universal e igualitário de todos os } \\
\text { munícipes às ações e serviços de promoção, } \\
\text { proteção e recuperação da saúde, sem } \\
\text { Qualquer discriminação (art. 205). }\end{array}$ & $\begin{array}{l}\text { Captação, adutoras e sub-adutoras, reservatórios, tratamento, } \\
\text { abastecimento de bairros e favelas. Otimização do Sistema } \\
\text { (controle de perdas). }\end{array}$ & $\begin{array}{l}\text { Índice de atendimento de água passou de } 97,6 \text { a } \\
98,0 \% \text {. } \\
\text { Volume de água faturado passou de } 78.257 .132 \\
\mathrm{~m}^{3} / \text { ano para } 81.213 .550 \mathrm{~m}^{3} / \text { ano. } \\
\text { Quantidade de economias ativas passou de } \\
296.596 \text { para } 348.150 \text {. } \\
\text { Îndice de perdas passou de } 33,8 \% \text { para } 26,7 \% \text {. } \\
\text { Investimento no sistema passou de } \mathrm{R} \$ \\
11.508 .542,00 \text { para } \$ \$ 1.309 .020,00 \\
\text { Recuperação de perdas de faturamento com } \\
\text { atuação em ligações clandestinas de água da } \\
\text { ordem de } 70 \% \text {. } \\
\text { Redução do tempo médio de atendimento à } \\
\text { ligações de água: de } 59 \text { dias para } 20 \text { dias } \\
\text { Recuperação da capacidade de abastecimento de } \\
\text { alguns bairros que apresentavam problemas } \\
\text { crônicos de desabastecimento. } \\
\text { Diminuição no número de reclamações de por falta } \\
\text { de água, de } 41 \text { reclamações por dia para } 0 \text {, em } \\
\text { alguns bairros. } \\
\text { Aumento da capacidade de captação no Atibaia em } \\
500 \text { litros por segundo, significando uma folga de } \\
\text { abastecimento para mais } 200 \text { habitantes. }\end{array}$ \\
\hline DIRETRIZES PLANO DIRETOR & $\begin{array}{c}\text { PROGRAMAS / PROJETOS / ATIVIDADES / OBRAS } \\
\text { IDENTIFICADAS NAS POLÍTICAS DE GOVERNO MUNICIPAL } \\
\text { PARA O PERÍODO } 1996-2000 \\
\end{array}$ & $\begin{array}{c}\text { RESULTADOS DE POLÍTICAS DE GOVERNO DO } \\
\text { ÓRGÃO GESTOR DOS SERVIÇOS } \\
\text { PERÍODO } 1996 \text { a } 2000 \\
\end{array}$ \\
\hline $\begin{array}{l}\text { Adotar uma política permanente de conservação } \\
\text { da água de abastecimento. } \\
\text { Definir critérios de cobrança das despesas com } \\
\text { a prestação dos serviços de produção e } \\
\text { distribuiçãã da água potável fluorada, mediante } \\
\text { a imposição de tarifas e taxas diferenciadas, } \\
\text { observados os aspectos técnicos, custos, a } \\
\text { destinação social dos serviços e o poder } \\
\text { aquisitivo da população beneficiada. }\end{array}$ & $\begin{array}{l}\text { Não ter vazamentos em reservatórios da empresa. } \\
\text { Implantar sistema para mensurar perdas gerais de água na } \\
\text { Sanasa, instalando } 26 \text { estações pitométricas e } 30 \\
\text { macromedidores; } \\
\text { Ter um programa de educação e esclarecimento do consumidor } \\
\text { com relação à conservação de água. }\end{array}$ & $\begin{array}{l}\text { Índice de perdas passou de } 33,8 \% \text { para } 26,7 \% \text {. } \\
\text { Recuperação de receita com programa de poços } \\
\text { tubulares da ordem de R\$ } 180.000 \text { por mês. } \\
\text { Há tarifas diferenciadas classificadas em } \\
\text { residencial padrão, residencial social, residencial } \\
\text { com ligação coletiva, residencial com pequeno } \\
\text { comércio, comercial, comercial em núcleos não } \\
\text { urbanizados e pública }\end{array}$ \\
\hline
\end{tabular}

Pop. Urbana em 1996: 891.670 hab.

Pop. Urbana em 2000: 950.533 hab.

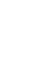

(1)

$\$$

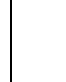

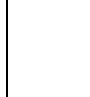


Assim, com relação ao aspecto esgoto para Campinas, tem-se que: a gestão municipal desse serviço mostra-se eficiente na medida em que os órgãos gestores vêm estabelecendo e implementando programas, projetos e obras em consonância com a Lei Orgânica da cidade e o Plano Diretor, como se observa na tabela 30 .

No entanto, mostra-se ineficaz quanto aos resultados no aspecto tratamento de esgotos, pois, de acordo com a Lei Orgânica, o município deveria ter no ano 2000 a totalidade de seus esgotos tratada e, como pode ser observado na tabela 30, o índice desse tratamento ao longo dos anos vem crescendo de forma muito lenta, não atingindo nem $10 \%$ do que é coletado, ou seja, no ano de 1996 apenas $1,7 \%$ dos esgotos coletados foram tratados, chegando no ano de 2000 com 5,6\% de tratamento, o que ainda é muito baixo, considerando-se principalmente que o número de economias ativas de esgoto aumentou em torno de $12 \%$, entre os anos de 1996 e 2000 , passando de 263.763 economias ativas para 298.342 economias ativas no ano de 2000 (ver tabela 30). Outro fato a considerar é que a população da cidade vem crescendo a taxas de 1,5\% a.a., demandando infra-estrutura necessária à sustentabilidade da cidade.

Em relação ao índice de atendimento de esgoto, este passou de $86 \%$ no ano de 1996 para $88 \%$ no ano de 2000 , nesse sentido vem se mostrando eficaz, no entanto, $12 \%$ da população urbana de Campinas não atendida com rede coletora representam quase 100.000 habitantes desprovidos dessa instalação.

Então, esse é um aspecto que merece maior atenção e investimentos dos gestores da cidade, pois, como pode ser observado nos resultados da tabela 30 , os investimentos no sistema de esgoto vêm diminuindo drasticamente. E, se observado em função da população, verifica-se que no ano de 1996 investia-se em torno de $\mathrm{R} \$ 18,00$ por habitante, passando ao ano de 2000 para $R \$ 5,6$ por 
habitante. Assim sendo, pode-se dizer que a gestão nesse aspecto tem-se mostrado pouco eficaz.

Outro ponto a observar é que o volume de esgoto coletado na cidade diminuiu ao longo do período 1996-2000 e, como a população da cidade vem crescendo a taxas consideráveis, provavelmente muitas casas não estão ligadas à rede coletora, cabendo ao órgão gestor tomar providências no sentido de proteger a saúde da população, pois, como estabelecido no artigo 205 da Lei Orgânica Municipal: "A saúde, entendida como a condição plena de bem-estar bio-psicosocial, é direito fundamental do ser humano e dever do Poder Público, assegurado através do desenvolvimento de: I - políticas sociais, econômicas e ambientais, que visem à eliminação do risco de doenças e de outros agravos à saúde; II - acesso universal e igualitário de todos os munícipes às ações e serviços de promoção, proteção e recuperação da saúde, sem qualquer discriminação" (CAMPINAS 2001).

Portanto, o gestor desse serviço deve ser mais eficaz no que tange a coleta e tratamento de esgoto, bem como ao monitoramento da quantidade de ligações e de economias ativas de esgoto. Para tanto, é necessário que esse órgão gestor realize maiores investimentos no sistema de esgoto e em medidas de educação ambiental, trabalhando a sociedade no sentido de mobilizá-la quanto à importância da disposição e tratamento adequados de seus efluentes, para a proteção da saúde e do meio ambiente. Assim, quanto ao tratamento, cabe ao órgão gestor tomar medidas mais eficazes no sentido de cumprir a lei orgânica da cidade, para que os esgotos gerados no município sejam $100 \%$ coletados e tratados, a fim de recuperar e conservar os mananciais da cidade os quais, por sua vez, são considerados os mais poluídos do Brasil e do Estado de São Paulo, protegendo e promovendo a saúde da população Campineira.

Com relação aos pontos de eficiência e eficácia da gestão destacados na tabela 31 , ao aspecto água, observa-se que: 
> Quanto à cobertura de água, $98 \%$ da população urbana é atendida, indo ao encontro das diretrizes da Lei Orgânica que diz respeito ao acesso universal de todos os munícipes às ações e serviços de promoção e proteção da saúde. A quantidade de economias ativas passou de 296.596 para 348.150 , ou seja, 51.554 economias ao longo de 5 anos. Se considerarmos que cada economia tem em média 3 pessoas, isso resulta em um atendimento em torno de 154.662 habitantes ao longo desses 5 anos, significando que o órgão gestor vem atendendo à demanda do crescimento populacional que girou em torno de 90.000 habitantes no período de 1996 a 2000. Observa-se também que, em relação a reclamações por falta de água, em alguns bairros diminuiu de 41 para 0 reclamações por dia.

Desse modo, com relação à eficiência e eficácia no aspecto de água, têmse que: a gestão municipal desse serviço mostra-se eficiente, à medida que os órgãos gestores estabelecem programas, projetos e obras em consonância com a Lei Orgânica da cidade, tendendo à universalização desse serviço, pois observase que $98 \%$ da cidade é atendida por esse serviço. Há que se comentar que, tendo o município 956.533 moradores na área urbana e que $98 \%$ dessa população é atendida com água, significa dizer que em torno de 19.000 habitantes são desprovidos de rede de água e que esse percentual vem se mantendo constante. O que pressupõe que o investimento tem sido para a manutenção e atendimento do crescimento vegetativo. Portanto, em relação à melhoria da eficácia desse serviço o órgão gestor deve investir na expansão do sistema, principalmente nas áreas que hoje são atendidas por torneiras coletivas e por caminhões-pipa, para que um maior número de pessoas se beneficie da água encanada. Para tanto, deve buscar maior articulação e integração com as diretrizes de expansão urbana constantes no Plano Diretor da cidade e, conforme já estabelecido pela Lei Orgânica, em seu artigo 203, instituir um plano de saneamento em consonância com esse Plano Diretor. 
Mostra-se também eficaz no que tange aos resultados alcançados em relação à evolução do volume faturado de água que, ao longo dos 5 anos ,cresceu em torno de $4 \%$, através de recuperação das perdas com atuação em ligações clandestinas e inadimplências de usuários. Merecem ser destacados também a redução dos índices de perdas físicas, que passou de $33,8 \%$ para $26,7 \%$, e a redução do tempo médio de atendimento à ligações de água, que passou de 59 dias para 20 dias.

\section{- Santo André}

Um dos aspectos importantes e relevantes a destacar na Lei Orgânica de Santo André é o tratamento especial dispensado ao saneamento básico, salientando em seus artigos 206 e 210 ações conjuntas e integradas com os municípios limítrofes e que o planejamento, controle e avaliação das ações de saneamento deverão contar com usuários domiciliares, comerciais e industriais, representantes dos trabalhadores, do Poder Legislativo e do Sistema Único de Saúde em nível municipal. Isso demonstra a abertura para a participação e também a visão de conjunto. Em seu artigo 212, coloca que compete ao Município participar da formulação da política estadual de saneamento básico. Mostra mais uma vez a importância atribuída à questão da articulação das políticas públicas.

Da mesma forma que a lei orgânica, o Plano Diretor reserva um capítulo especial para o saneamento, englobando o sistema de água, esgoto, drenagem, limpeza urbana e prevenção de zoonoses. No artigo 31, inciso 2, é salientado que, em função de o abastecimento de água e esgoto ser integrado ao sistema adutor metropolitano, o Poder Executivo poderá contratar a Companhia Estadual de Saneamento para o fornecimento de água potável, estabelecendo condições de quantidade, regularidade e qualidade. Nesse sentido, o SEMASA compra água por atacado da SABESP, a qual é produzida no Município de São Paulo. Esse é um 
diferencial que merece ser ponderado quando da análise sobre eficácia na gestão desses serviços.

Da mesma forma acontece com o sistema de esgoto, pois o SEMASA faz a coleta e a SABESP realiza o tratamento, porém, na zona de expansão urbana do município de Santo André, é previsto que o poder executivo tratará da implantação de sistemas individuais de tratamento de esgoto.

Ao destacar as diretrizes contidas na Lei Orgânica e no Plano Diretor de Santo André, e cruzando-as com os programas, projetos, atividades, obras e metas, contidas nas políticas de governo do município, foram identificados pontos na eficiência e na eficácia da gestão em relação aos aspectos de esgoto e de água, conforme apresentados nas tabelas 32 e 33. 
Tabela 32. Santo André - Aspecto Esgoto.

LeI ORgânica e Plano DiRetor X Programas e Projetos X Resultados

\begin{tabular}{|c|c|c|}
\hline $\begin{array}{c}\text { DIRETRIZES DA LEI ORGÂNICA } \\
\text { De } 1990\end{array}$ & $\begin{array}{c}\text { PROGRAMAS / PROJETOS / ATIVIDADES / OBRAS } \\
\text { IDENTIFICADAS NAS POLIITICAS DE GOVERNO MUNICIPAL } \\
\text { PARA O PERÍODO } 1996-2000\end{array}$ & $\begin{array}{c}\text { RESULTADOS DE POLÍTICAS DE GOVERNO DO } \\
\text { ÓRGÃO GESTOR DOS SERVIÇOS } \\
\text { PERÍODO } 1996 \text { a } 2000\end{array}$ \\
\hline $\begin{array}{l}\text { Formular e implantar a política municipal de } \\
\text { saneamento básico, bem como controlar, } \\
\text { fiscalizar e avaliar seu cumprimento; } \\
\text { participar da formulação da política estadual de } \\
\text { saneamento básico; planejar, projetar, executar, } \\
\text { operar e manter os serviços de abastecimento } \\
\text { de água e esgotamento sanitário; }\end{array}$ & $\begin{array}{l}\text { A Política Municipal de Gestão e Saneamento Ambiental foi } \\
\text { elaborada e aprovada em } 1998 \text { pela lei } 7.733 \text {. } \\
\text { Elaboração do Plano Municipal de Gestão e Saneamento } \\
\text { Ambiental. }\end{array}$ & $\begin{array}{l}\text { Índice de atendimento de esgoto passou de } 96 \% \text { a } \\
93 \% \text {. } \\
\text { Índice de esgoto tratado }(0 \%) \text { pois a SABESP é } \\
\text { quem trata. } \\
\text { Investimento de esgoto passou de } \mathrm{R} \$ 4.278 .000,00 \\
\text { para } \mathrm{R} \$ 451.583,00 \text {. } \\
\text { Índice de esgoto tratado pelo SEMASA }(0 \%) \text {. }\end{array}$ \\
\hline $\begin{array}{l}\text { Tarifa cobrada pelos serviços, efetivamente } \\
\text { prestados, a qual poderá ser diferenciada em } \\
\text { função do consumo e da capacidade econômica } \\
\text { do usuário, definidos em lei (art. 214) }\end{array}$ & $\begin{array}{l}\text { Não foi encontrado de forma explícita um programa para a } \\
\text { discussão do sistema tarifário porém, foram encontradas as } \\
\text { tarifas dos serviços. }\end{array}$ & $\begin{array}{l}\text { Há tarifas residencial, residencial social, comercial } \\
\text { e industrial. }\end{array}$ \\
\hline DIRETRIZES DO PLANO DIRETOR & $\begin{array}{c}\text { PROGRAMAS / PROJETOS / ATIVIDADES / OBRAS } \\
\text { IDENTIFICADAS NAS POLITIICAS DE GOVERNO MUNICIPAL } \\
\text { PARA O PERÍODO } 1996-2000 \\
\end{array}$ & $\begin{array}{c}\text { RESULTADOS DE POLÍTICAS DE GOVERNO DO } \\
\text { ÓRGÃO GESTOR DOS SERVIÇOS } \\
\text { PERÍODO } 1996 \text { a } 2000\end{array}$ \\
\hline $\begin{array}{l}\text { A coleta e interceptação dos esgotos sanitários } \\
\text { nas áreas pertencentes à Bacia do Alto } \\
\text { Tamanduateí terão diretrizes contemplando: a } \\
\text { melhoria e a otimização da coleta de esgotos, } \\
\text { através da rede pública separadora absoluta; } \\
\text { coletores - tronco e interligações necessárias ao } \\
\text { encaminhamento dos esgotos à ETE ABC } \\
\text { projetados, construídos e operados em } \\
\text { colaboração com a Companhia Estadual } \\
\text { responsável pelo tratamento dos esgotos na } \\
\text { Região Metropolitana de São Paulo, através de } \\
\text { convênio firmado pela mesma (art. 35). } \\
\text { Na Zona de Expansão Urbana o Poder } \\
\text { Executivo tratará da implantação de sistemas } \\
\text { individuais de tratamento e disposição dos } \\
\text { esgotos sanitários, utilizando-se da infiltração no } \\
\text { solo, exceto nos locais onde, em função da } \\
\text { ocupação consolidada, a solução coletiva com a } \\
\text { reversão dos esgotos para a bacia do } \\
\text { Tamanduateí seja a mais indicada (art.36). }\end{array}$ & $\begin{array}{l}\text { Construção de estação de recuperação de água abrangendo } \\
\text { serviços de esgotos domésticos para produção de água } \\
\text { industrial, incluindo equipamentos. } \\
\text { Executar os projetos e obras de saneamento integrado para as } \\
\text { favelas do município. } \\
\text { Elaboração de projetos e execução de extensão de redes de } \\
\text { esgoto urbana nas áreas ainda não atendidas pelo SEMASA. } \\
\text { Elaboração de estudos de viabilidade, projeto e obra de sistemas } \\
\text { de reuso de água para fins industriais. } \\
\text { Executar obras de rede de esgoto em Paranapiacaba. }\end{array}$ & $\begin{array}{l}\text { Urbanização e conseqüente regularização de redes } \\
\text { e ligações de água e esgotos nos núcleos de } \\
\text { favelas. } \\
\text { Complementação dos coletores troncos } \\
\text { implantados pela SABESP no município e início de } \\
\text { operação do sistema, incluindo o tratamento pela } \\
\text { ETE ABC. }\end{array}$ \\
\hline
\end{tabular}


Tabela 33. Santo André - Aspecto Água.

LeI Orgânica e Plano Diretor X Programas e Projetos X Resultados

\begin{tabular}{|c|c|c|}
\hline $\begin{array}{c}\text { DIRETRIZES DA LEI ORGÂNICA } \\
\text { de } 1990\end{array}$ & $\begin{array}{c}\text { PROGRAMAS / PROJETOS / ATIVIDADES / OBRAS } \\
\text { IDENTIFICADAS NAS POLITITICAS DE GOVERNO MUNICIPAL } \\
\text { PARA O PERÍODO } 1996-2000\end{array}$ & $\begin{array}{c}\text { RESULTADOS DE POLÍTICAS DE GOVERNO DO } \\
\text { ÓRGÃO GESTOR DOS SERVIÇOS } \\
\text { PERÍODO } 1996 \text { a } 2000\end{array}$ \\
\hline $\begin{array}{l}\text { Compete ao Município planejar, projetar, } \\
\text { executar, operar os serviços de abastecimento } \\
\text { de água }\end{array}$ & $\begin{array}{l}\text { Projetos e obras para implantação ETA } 500 \text { l/s. } \\
\text { Executar redes de água em Paranapiacaba. } \\
\text { Elaboração de projetos e execução de extensão de redes de } \\
\text { água nas áreas ainda não atendidas pelo SEMASA. }\end{array}$ & $\begin{array}{l}\text { Índice de atendimento de água passou de } 99 \% \\
\text { para } 96 \% \text {. } \\
\text { Volume de água faturado passou de } 17.731 .500 \\
\mathrm{~m}^{3} \text { /ano para } 38.113 .100 \mathrm{~m}^{3} / \mathrm{ano} \text {. } \\
\text { Investimento passou de } \mathrm{R} \$ 29.397 .000,00 \text { para } \mathrm{R} \$ \\
786.935,00 \text {. }\end{array}$ \\
\hline DIRETRIZES DO PLANO DIRETOR & $\begin{array}{c}\text { PROGRAMAS / PROJETOS / ATIVIDADES / OBRAS } \\
\text { IDENTIFICADAS NAS POLÍTICAS DE GOVERNO MUNICIPAL } \\
\text { PARA O PERÍODO } 1996 \text { - } 2000\end{array}$ & $\begin{array}{c}\text { RESULTADOS DE POLIITICAS DE GOVERNO DO } \\
\text { ÓRGÃO GESTOR DOS SERVIÇOS } \\
\text { PERÍODO } 1996 \text { a } 2000\end{array}$ \\
\hline $\begin{array}{l}\text { Em função da integração com o Sistema Adutor } \\
\text { Metropolitano, o Poder Executivo, através do } \\
\text { órgão competente, poderá contratar a } \\
\text { Companhia Estadual de Saneamento para o } \\
\text { fornecimento de água potável, estabelecendo as } \\
\text { condições de quantidade, regularidade e } \\
\text { qualidade. }\end{array}$ & A SABESP produz água e o SEMASA distribui & $\begin{array}{l}\text { Quantidade de economias ativas passou de } \\
182.330 \text { para } 236.972 \text {. }\end{array}$ \\
\hline
\end{tabular}


Assim, analisando a tabela 32, com relação à eficiência e eficácia da gestão de Santo André quanto ao aspecto esgoto, tem-se que: a gestão municipal desse serviço mostra-se eficiente, à medida que, os órgãos gestores vêm estabelecendo programas, projetos e atividades em consonância com a Lei Orgânica da Cidade e com o Plano Diretor.

Mostra-se eficaz em relação ao atendimento de esgoto, mesmo tendo apresentado uma variação nesse índice de cobertura, que passou de $96 \%$ para $93 \%$, pois é um índice alto de atendimento se comparado por exemplo com Campinas. No entanto, essa evolução negativa indica que o órgão gestor está deixando de priorizar as questões relacionadas a esse sistema, considerando principalmente que a evolução da população vem diminuindo. Isso pode ser notado também ao olhar a evolução negativa do volume de recursos que vem sendo aplicado no sistema de esgoto (ver tabela 32).

Outro ponto a ser destacado como indicador de queda na eficácia dessa gestão é que o número de economias de esgotos aumentou de 175.890 para 230.013 , enquanto o volume de esgoto coletado diminuiu de $41.756 .000 \mathrm{~m}^{3} / \mathrm{ano}$ para $32.083 .900 \mathrm{~m}^{3} / a n o$, significando que muitas casas não estão conectadas à rede coletora.

Quanto ao índice de tratamento de esgoto, não é possível dizer se o órgão gestor está sendo eficaz, pois o tratamento é realizado pela SABESP na ETE ABC, considerando para efeito deste trabalho como "sem aferição".

Portanto, o órgão gestor desse serviço precisa ser mais eficaz no que tange à questão da expansão do atendimento e principalmente à otimização da coleta do esgoto e monitoramento das ligações à rede coletora, visando à proteção do meio ambiente e sobretudo da saúde da população.

Quanto ao aspecto água, tem-se que essa gestão é eficaz, se considerada do ponto de vista do índice de atendimento, que é de $95 \%$. No entanto, esse 
índice passou de $99 \%$ para $96 \%$, e os investimentos no sistema de água também mostraram-se decrescentes. Esta é uma situação que merece ser destacada uma vez que em Santo André o crescimento populacional tem sido negativo, passou de 632.493 habitantes para 625.564 habitantes.

Assim, é preciso que nas políticas de governo desse órgão gestor, questões de abastecimento de água e de esgotamento sanitário, sejam consideradas com maior intensidade. Como o SEMASA realiza gestão integrada dessas questões com as de drenagem, resíduos sólidos, meio ambiente e defesa civil, provavelmente as prioridades de investimentos direcionadas nestas outras áreas, ou seja, utilizando-se de subsídios cruzados entre elas.

\section{- São José dos Campos}

Na Lei Orgânica de São José dos Campos, há que se destacar a importância atribuída à realização de ações integradas no que tange às questões do controle ambiental, da saúde e de saneamento, conforme diz seu artigo 277: "É de competência do Município, exercida pela Secretaria Municipal de Saúde, planejar e executar as ações de controle do meio ambiente e de saneamento básico, no âmbito do Município, em articulação com os demais órgãos governamentais" (art.277). Assim, quanto a essa integração, as investigações documentais mostraram que há um efetivo intercâmbio e participação da administração municipal no desenvolvimento dos programas de saneamento básico. Tal afirmação pode ser notada, ao observar as diretrizes apontadas nos planos plurianuais e nos orçamentos do Município, levando a crer que, quando os partidos políticos do gestor estadual dos serviços de água e esgoto e do gestor da cidade compartilham com os mesmos ideais, as diferenças na eficiência e na eficácia da gestão vêm à tona.

O Plano Diretor de São José dos Campos apresenta o saneamento básico no capítulo do Planejamento Territorial, o que é uma visão bastante peculiar e 
interessante, sob o ponto de vista de que o saneamento básico tem um papel fundamental no planejamento, pois é um elemento estruturador do crescimento da cidade, da saúde ambiental e da saúde humana. É peculiar também quanto à menção que faz em relação aos programas e projetos prioritários para a política municipal de meio ambiente, dentre eles: programa de controle e tratamento de esgotos domésticos, programa de controle da qualidade das águas. De fato a administração municipal vem trabalhando essas questões, as quais podem ser observadas na tabela 34 .

Ao destacar as diretrizes contidas na Lei Orgânica e no Plano Diretor, cruzando-as com programas, projetos, atividades, obras e metas, e analisando-as do ponto de vista da articulação e integração desses programas entre gestores municipal e estadual, é que foram destacados os pontos na eficiência e na eficácia da gestão em relação aos aspectos de esgoto e de água, conforme apresentados nas tabelas 34 e 35 . 
Tabela 34. São José dos Campos - Aspecto Esgoto.

LeI ORgânica e PLANo DiRETOR X PRogramas e PRoJetos

Pop. Urbana em 1996: 481.265 hab.

Pop. Urbana em 2000: 538.909 hab.

\begin{tabular}{|c|c|}
\hline $\begin{array}{l}\text { DIRETRIZES DA LEI ORGÂNICA } \\
\text { de } 1990\end{array}$ & $\begin{array}{c}\text { PROGRAMAS / PROJETOS / ATIVIDADES / OBRAS } \\
\text { IDENTIFICADOS NAS POLIITICAS DE GOVERNO MUNICIPAL } \\
\text { PARA O PERÍODO } 1996-2000\end{array}$ \\
\hline $\begin{array}{l}\text { Promover diretamente, em convênios ou em colaboração com a União, Estado e } \\
\text { outras instituições, programas para melhorias de saneamento básico (art. 22) }\end{array}$ & $\begin{array}{l}\text { Democratização do saneamento básico, estendendo a todas as parcelas da } \\
\text { população a coleta de esgotos. }\end{array}$ \\
\hline \multirow[t]{3}{*}{$\begin{array}{l}\text { O Poder Público Municipal deverá dar adequado tratamento e destino final aos } \\
\text { efluentes dos esgotos de origem doméstica, diretamente ou por concessão (art.232). }\end{array}$} & $\begin{array}{l}\text { Implantação de rede de esgoto, estações elevatórias em vários bairros, mediante } \\
\text { convênio com a SABESP. }\end{array}$ \\
\hline & $\begin{array}{l}\text { Expansão do sistema de esgoto; Implantação e reforma das Estações de } \\
\text { Tratamento de Esgoto; Assistência aos bairros que não possuem rede de esgoto. }\end{array}$ \\
\hline & $\begin{array}{l}\text { Implantação, adequação e ampliação de redes coletoras e de afastamento de } \\
\text { esgotos (convênios e/ou contratação de obras). }\end{array}$ \\
\hline DIRETRIZES DO PLANO DIRETOR & $\begin{array}{c}\text { PROGRAMAS / PROJETOS / ATIVIDADES / OBRAS } \\
\text { IDENTIFICADOS NAS POLÍTICAS DE GOVERNO MUNICIPAL } \\
\text { PARA O PERÍODO } 1996-2000\end{array}$ \\
\hline $\begin{array}{l}\text { São programas e projetos prioritários da Política Municipal do Meio Ambiente: } \\
\text { Programa de controle e tratamento de esgotos domésticos do Município; } \\
\text { cadastramento das ligações clandestinas de esgoto; estudo sobre as alternativas de } \\
\text { controle e tratamento de esgotos domésticos para o Município (art. 39). }\end{array}$ & $\begin{array}{l}\text { Implantação de rede de esgoto, estações elevatórias em vários bairros, mediante } \\
\text { convênio com a SABESP. }\end{array}$ \\
\hline
\end{tabular}

controle e tratamento de esgotos domésticos para o Município (art 39).

\begin{tabular}{|l|}
\hline \multicolumn{1}{|c|}{ RESULTADOS DE POLITICAS DE GOVERNO DO ÓRGÃO GESTOR DOS SERVIÇOS } \\
PERÍODO 1996 a 2000
\end{tabular}


Tabela 35. São José dos Campos - Aspecto Água.

Lei Orgânica e Plano Diretor X Programas e Projetos

\begin{tabular}{|c|c|}
\hline $\begin{array}{l}\text { DIRETRIZES DA LEI ORGÂNICA } \\
\text { de } 1990\end{array}$ & $\begin{array}{c}\text { PROGRAMAS / PROJETOS / ATIVIDADES / OBRAS } \\
\text { IDENTIFICADOS NAS POLÍTICAS DE GOVERNO MUNICIPAL } \\
\text { PARA O PERÍODO 1996 - } 2000\end{array}$ \\
\hline $\begin{array}{l}\text { Promover diretamente, em convênios ou em colaboração com a União, Estado e } \\
\text { outras instituições, programas para melhorias de saneamento básico (art. 22). }\end{array}$ & $\begin{array}{l}\text { Expansão do sistema de abastecimento de água. } \\
\text { Implantação de rede de água reservatórios, emissários, estações elevatórias em } \\
\text { vários bairros, mediante convênio com a SABESP. }\end{array}$ \\
\hline DIRETRIZES DO PLANO DIRETOR & $\begin{array}{c}\text { PROGRAMAS / PROJETOS / ATIVIDADES / OBRAS } \\
\text { IDENTIFICADOS NAS POLIITICAS DE GOVERNO MUNICIPAL } \\
\text { PARA O PERÍODO } 1996-2000\end{array}$ \\
\hline $\begin{array}{l}\text { A política de infra-estrutura do Município observará as seguintes diretrizes: instituir e } \\
\text { regulamentar o Conselho Municipal de Saneamento Básico com o objetivo de } \\
\text { fomentar uma política municipal de saneamento autônoma e peculiar às } \\
\text { necessidades locais e regionais; Rever o contrato de concessão dos serviços com a } \\
\text { SABESP, visando melhorar as condições de saneamento básico do Município (art. } \\
\text { 40). }\end{array}$ & $\begin{array}{l}\text { Democratização do saneamento básico, estendendo a todas as parcelas da } \\
\text { população o abastecimento de água. } \\
\text { O contrato de concessão vence em } 2006\end{array}$ \\
\hline
\end{tabular}

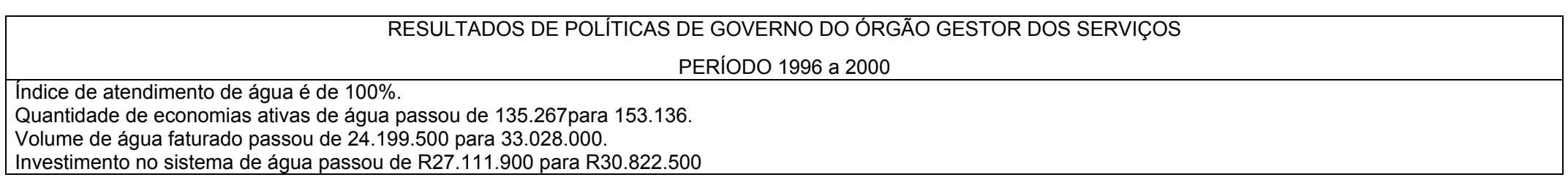


Com relação ao quesito eficiência na gestão estadual dos serviços de água e esgoto de São José dos Campos, a análise foi efetuada de forma um pouco diferente daquela realizada para a gestão municipal, uma vez que não foram disponibilizados Planos que permitissem a identificação de programas, projetos e atividades, provenientes das políticas de governo do órgão gestor desses serviços, que seriam comparados com as diretrizes da Lei Orgânica e do Plano Diretor. Assim, esse quesito foi analisado do ponto de vista da articulação e integração dos programas e projetos estabelecidos pelo gestor municipal (ver tabela 34 e 35 ) em parceria com o gestor dos serviços de água e esgoto, identificados nos orçamentos anuais de São José dos Campos e, também, em entrevistas informais com profissionais - chefe da Secretaria Municipal de Economia desse Município. Nesse contexto, a gestão estadual, no aspecto esgoto e água, mostra-se eficiente.

Quanto ao quesito eficácia, tanto no aspecto esgoto, quanto no aspecto água, a análise se deu de forma pontual, ou seja, somente focada nos resultados obtidos pelo questionário, não podendo considerar o cruzamento com programas, projetos, obras e metas que o órgão gestor dos serviços de água e esgoto estabelece em seus Planos de Investimentos, pelos motivos já expostos, o que causou um mascaramento em termos referenciais, no momento das conclusões finais aferidas. Desse modo, com relação à eficácia da gestão estadual, no aspecto esgoto, tem-se que: a gestão estadual desse serviço mostra-se eficaz quanto ao atendimento de esgoto por apresentar-se com índice de 99\%, significando que quase toda a população Joanense é atendida com rede coletora. Quanto ao índice de tratamento de esgoto, considera-se que a gestão estadual também é eficaz, pois este índice está em $41 \%$ do que é coletado. O referencial para esta afirmação foi o município de Campinas, que apresenta um índice de tratamento de $10 \%$. Porém, é necessário que esse órgão gestor realize maiores investimentos no sistema de esgoto, em conjunto com o órgão municipal no planejamento da cidade, pois, conforme se observa na tabela 34 , estes vêm 
decrescendo ao longo dos 5 anos e, por outro lado, o número de economias ativas de esgoto mostra-se crescente, assim como a população, demandando infraestruturas para sua sustentabilidade.

Com relação à eficácia no aspecto água, a gestão estadual mostra-se eficaz, na medida em que, seu atendimento é considerado pela Companhia como $100 \%$. Nesse sentido, os investimentos no sistema de água são para a manutenção do sistema, atendimento ao crescimento vegetativo da população e atendimento aos municípios pertencentes a Unidade de Negócios do Vale do Paraíba. Pode ser observado, também, que o número de economias de água passou de 135.267 para 153.136, ou seja, 17.869 economias atendidas ao longo de 5 anos. Se consideramos que cada economia tem 3 pessoas, isso representa um atendimento de 53.607 pessoas. Ao compararmos esse número com o crescimento da população urbana nesse mesmo período, ou seja, de 1996 a 2000, tem-se 50.000 habitantes, concluindo, então, que o órgão gestor desse serviço vem mantendo constante atendimento ao longo desses 5 anos, o que vem confirmar a eficácia nesse aspecto.

\section{- Santos}

A Lei Orgânica de Santos tem poucas diretrizes para o saneamento, entre as quais, destacam-se aquelas contidas no artigo 156, que diz que o município consignará, anualmente, no orçamento, percentual para preservação e recuperação do meio ambiente. Assim, foram identificados nos orçamentos anuais, período 1996-2000, programas e projetos voltados ao saneamento básico, mostrando a intenção do governo municipal na articulação e integração com políticas públicas locais. Destaca-se também o artigo 6 dessa Lei Orgânica, apontando que compete ao município legislar sobre assuntos de interesse local e, nesse sentido, foi identificada nos orçamentos anuais do município a intenção da 
municipalização do saneamento. Essa é uma discussão que ainda está em negociação entre os governos municipal e estadual.

Com relação ao Plano Diretor, as diretrizes estão bastante reduzidas, uma vez que em Santos a atualização do Plano é realizada por meio de Lei Complementar e não por Plano Substitutivo. Assim sendo, foi identificada na última Lei Complementar a seguinte diretriz "Promover a extensão da rede de saneamento básico nas áreas urbana e de expansão urbana". Desse modo, identificou-se nas políticas de governo, projetos para implantação do sistema de captação na Área Continental e para obras de esgotamento sanitário nos morros de Santos, conforme podem ser vistos na tabela 38.

Ao destacar as diretrizes contidas na Lei Orgânica e no Plano Diretor de Santos, e cruzando-as com programas, projetos, atividades, obras e metas identificados nos orçamentos anuais do município, percebeu-se a ausência de articulação e integração destes programas entre gestores municipal e estadual, conforme descrevem as tabelam 36 e 37 . Portanto ao destacar pontos na eficiência e na eficácia da gestão em relação aos aspectos de esgoto e de água, considerou-se "sem aferição", para este Município, como pode ser observado na tabelas 39 a 42 . 
Tabela 36. Santos - Aspecto Esgoto.

LeI ORgânica X PRogramas e PRojetos

Pop. Urbana em 1996: 415.579 hab.

Pop. Urbana em 2000: 415.543 hab.

\begin{tabular}{|l|l|}
\hline \multicolumn{1}{|c|}{\begin{tabular}{|l} 
DIRETRIZES DA LEI ORGÂNICA \\
de 1990
\end{tabular}} & \multicolumn{1}{|c|}{$\begin{array}{c}\text { PROGRAMAS / PROJETOS / ATIVIDADES / OBRAS } \\
\text { IDENTIFICADOS NAS POLÍTICAS DE GOVERNO MUNICIPAL } \\
\text { PARA O PERIODO 1996 - 2000 }\end{array}$} \\
\hline Compete ao município: legislar sobre assuntos de interesse local. (art. 6.) & $\begin{array}{l}\text { Municipalização do saneamento visando controle das ações do saneamento básico no } \\
\text { ambito municipal. } \\
\text { Instalação, ampliação e manutenção de redes coletoras de esgotos. }\end{array}$ \\
\hline $\begin{array}{l}\text { O município consignará, anualmente, no orçamento, percentual para } \\
\text { preservação e recuperação do meio ambiente (art. 156). }\end{array}$ & $\begin{array}{l}\text { Desenvolver projetos para implantação de tratamento de esgotos em áreas não } \\
\text { atingidas pela SABESP. } \\
\text { Identificação de ligações clandestinas de esgotos. } \\
\text { Implantação de rede coletora de esgoto nos morros de Santos. }\end{array}$ \\
\hline
\end{tabular}

RESULTADOS DE POLITICAS DE GOVERNO DO ÓRGÃO GESTOR DOS SERVIÇOS

Indice de atendimento de esgoto passou de $91 \%$ para $95 \%$

PERÍODO 1996 a 2000

Índice de esgoto tratado passou de $91 \%$ para $95 \%$.

Quantidade de economias de esgoto passou de 162.874 para 165.469

Quantidade de

Receita operacional passou R\$ $32.525 .445,00$ pa

Receita operacional passou
Despesa operacional (?) não disponibilizada 
Tabela 37. Santos - Aspecto - Água.

LEI ORgÂNICA -X PROGRAMAS E PROJETOS X RESULtAdos
DIRETRIZES DA LEI ORGÂNICA de 1990
PROGRAMAS / PROJETOS / ATIVIDADES / OBRAS IDENTIFICADOS NAS POLÍTICAS DE GOVERNO MUNICIPAL PARA O PERÍODO $1996-2000$

As ações do saneamento executadas em consonância com o Estado, devem prever a utilização racional da água, do solo e do ar, de modo compatível com a preservação e melhoria da qualidade da saúde pública e do meio ambiente (art. 175).

\section{RESULTADOS DE POLITICAS DE GOVERNO DO ÓRGÃO GESTOR DOS SERVIÇOS}

Índice de atendimento de água é de $100 \%$

Quantidade de economias ativas passou de 176.580 para 175.971

Investimento no sistema de água passou de $\mathrm{R} \$ 3.961 .406$ para $\mathrm{R} \$ 1.246 .787$

Receita operacional dos serviços de água passou de $\mathrm{R} \$ 39.690 .779,00$ para $\mathrm{R} \$ 49.894 .280,00$

Despesa operacional (?) não disponibilizada.

\section{Tabela 38. Santos - Aspecto -Água e Esgoto.}

Plano DiRETOR X PROgRamas E PROJetos

\begin{tabular}{|l|l|}
\hline \multicolumn{1}{|c|}{ DIRETRIZES DO PLANO DIRETOR } & $\begin{array}{c}\text { PROGRAMAS / PROJETOS / ATIVIDADES / OBRAS } \\
\text { IDENTIFICADOS NAS POLITICAS DE GOVERNO MUNICIPAL } \\
\text { PARA O PERIOODO 1996 - 2000 }\end{array}$ \\
\hline $\begin{array}{l}\text { Promover a extensão da rede de saneamento básico nas áreas urbana e de } \\
\text { expansão urbana (artigo 15). }\end{array}$ & $\begin{array}{l}\text { Obras de esgotamento sanitário nos morros de Santos. } \\
\text { Implantação do sistema de captação na Área Continental visando dotar essa de } \\
\text { saneamento básico necessário ao seu desenvolvimento }\end{array}$ \\
\hline
\end{tabular}

A diretriz encontrada no Plano Diretor de Santos em relação aos aspectos água e esgoto foi apenas uma. Assim, juntou-se o aspecto água e esgoto em uma única tabela. 
Com relação ao quesito eficiência da gestão estadual dos serviços de água e esgoto para o Município de Santos, não foi possível proceder a análise de forma similar àquelas realizadas para os Municípios de Campinas e Santo André, uma vez que não foram disponibilizados os Planos contendo programas, projetos e atividades, provenientes das políticas de governo do órgão gestor desses serviços, que seriam comparadas com as diretrizes da Lei Orgânica e do Plano Diretor. Não sendo possível também proceder da mesma forma que aquela realizada para o Município de São José dos Campos, que foi em relação à integração e articulação do gestor da cidade com o gestor dos serviços de água e esgoto, pois não foram encontrados nos orçamentos municipais programas, projetos ou atividades que demonstrassem tais evidências. Portanto, no aspecto esgoto e água, em relação a eficiência na gestão estadual desses serviços para Santos, não foi possível aferir. Assim sendo, nas tabelas 39 e 40, a eficiência tanto para o aspecto esgoto como o aspecto de água foi representada como "sem aferição".

Quanto ao quesito eficácia na gestão para os aspectos esgoto e água, a análise procedeu pontual, ou seja, somente focada nos resultados obtidos pelo questionário, não podendo considerar o cruzamento com programas, projetos, obras e metas que o órgão gestor dos serviços de água e esgoto estabelece em seus Planos de Investimentos, pelos motivos já expostos, o que causou um mascaramento em termos referenciais, no momento das conclusões finais aferidas. Assim sendo, foi analisada somente a eficácia da gestão estadual em função dos resultados quantitativos daquele órgão gestor.

Desse modo, com relação à eficácia da gestão estadual no aspecto esgoto, tem-se que: a gestão estadual desse serviço mostra-se eficaz quanto ao atendimento de esgoto por apresentar-se com índice de 95\%, significando que quase toda a população santista é atendida com rede coletora. No entanto, esse percentual de $5 \%$ sem atendimento representa em torno de 20.000 habitantes, os quais poderiam ser contemplados com esses serviços se assim 
for o planejamento do município, pois percebe-se que a receita operacional é alta se comparada com o investimento ao longo desses 5 anos.

Quanto ao índice de tratamento de esgoto, considera-se que a gestão estadual também é eficaz, pois este índice está em 95\% do que é coletado, no entanto para fins desta pesquisa foi considerado como "sem aferição", de forma similar ao dito anteriormente para o quesito eficiência.

Com relação à eficácia no aspecto água, a gestão estadual mostra-se eficaz, na medida em que, seu atendimento é considerado pela Companhia como $100 \%$. Assim, os investimentos no sistema de água são para a manutenção do sistema, atendimento ao crescimento vegetativo da população e atendimento a outros municípios da Região Metropolitana de Santos, pertencentes a Unidade de Negócios da Baixada Santista, conforme informação daquela Companhia. Se considerarmos, que a população de Santos manteve-se praticamente constante de 1996 a 2000; que a receita operacional desses serviços é alta em relação aos investimentos, logo, é possível que o gestor estadual atenda, também, áreas de interesse local, em conformidade com as diretrizes do Plano Diretor da cidade buscando assim ter uma cidade saudável.

As discussões realizadas para esses quatro municípios estão representadas esquematicamente nas tabelas 39 a 42. Assim sendo, passa-se, finalmente, para a conclusão deste trabalho, como segue no item 6. 


\section{QUESITO EFICIÊNCIA}

Tabela 39. Diretrizes da Lei Orgânica e do Plano Diretor X Programas e Projetos (1996-2000).

\begin{tabular}{|l|c|c|c|c|}
\hline \multicolumn{1}{|c|}{ ASPECTO - ESGOTO } & \multicolumn{2}{|c|}{ GESTÃO ESTADUAL } & \multicolumn{2}{c|}{ GESTÃO MUNICIPAL } \\
\cline { 2 - 5 } & $\begin{array}{c}\text { São José dos } \\
\text { Campos }\end{array}$ & Santos & Campinas & Santo André \\
\hline $\begin{array}{l}\text { Programas, Projetos, Atividades } \\
\text { Metas e Obras }\end{array}$ & Eficiente & Sem aferição* & Eficiente & Eficiente \\
\hline
\end{tabular}

*Ler explicação sobre a notificação "sem aferição" na página 152.

TABELA 40. Diretrizes da Lei Orgânica e do Plano Diretor x Programas e Projetos (1996-2000).

\begin{tabular}{|l|c|c|c|c|}
\hline \multicolumn{1}{|c|}{ ASPECTO - ÁGUA } & \multicolumn{2}{|c|}{ GESTÃO ESTADUAL } & GESTÃO MUNICIPAL \\
\cline { 2 - 5 } & $\begin{array}{c}\text { São José dos } \\
\text { Campos }\end{array}$ & Santos & Campinas & Santo André \\
\hline $\begin{array}{l}\text { Programas, Projetos, Atividades } \\
\text { Metas e Obras }\end{array}$ & Eficiente & Sem aferição* & Eficiente & Eficiente \\
\hline
\end{tabular}

Legenda

Eficiente

Sem aferição 


\section{QUESITO EFICÁCIA}

TABELA 41. Diretrizes da Lei Orgânica e do Plano Diretor x Programas e Projetos x Resultados Alcançados (1996-2000).

\begin{tabular}{|l|c|c|c|c|}
\hline \multirow{2}{*}{ ASPECTO - ESGOTO } & \multicolumn{2}{|c|}{ GESTÃO ESTADUAL } & \multicolumn{2}{c|}{ GESTÃO MUNICIPAL } \\
\cline { 2 - 5 } & $\begin{array}{c}\text { São José dos } \\
\text { Campos }\end{array}$ & Santos & Campinas & Santo André \\
\hline Índice de Cobertura de Esgoto & Eficaz & Sem aferição* & Sem aferição* \\
\hline Índice de Tratamento de Esgoto & Eficaz & Sem aferição* & Ineficaz & S \\
\hline
\end{tabular}

*Ler explicação sobre a notificação "sem aferição" nas páginas 152 e 153.

TABELA 42. Diretrizes da Lei Orgânica e do Plano Diretor x Programas e Projetos x Resultados Alcançados (1996-2000)

\begin{tabular}{|c|c|c|c|c|}
\hline \multirow{2}{*}{ ASPECTO - ÁGUA } & \multicolumn{2}{|c|}{ GESTÃO ESTADUAL } & \multicolumn{2}{c|}{ GESTÃO MUNICIPAL } \\
\cline { 2 - 5 } & $\begin{array}{c}\text { São José dos } \\
\text { Campos }\end{array}$ & Santos & \multicolumn{2}{c|}{ Campinas } \\
\hline Índice de Cobertura de Água & Eficaz & Sem aferição* & Eficaz & Eficaz \\
\hline
\end{tabular}

* Ler explicação sobre a notificação “sem aferição” nas páginas 152 e 153.

Legenda

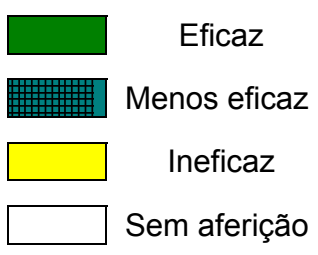




\section{Conclusão}

Ao se iniciar as conclusões deste trabalho, cabe relembrar as definições de políticas públicas, políticas de governo, eficiência e eficácia que nortearam o seu desenvolvimento. Como política de governo, aquela feita por e para determinada gestão governamental. Como política pública, aquela definida por lei, promulgada pelo poder legislativo e sancionada pelo executivo. Como eficiência, quando os gestores dos serviços estabelecem programas, projetos, obras e atividades, para que recursos sejam aplicados no sentido de levar água em qualidade e em quantidade suficiente à população, coletar e tratar os efluentes, minimizando a poluição dos recursos hídricos e aumentando a qualidade de vida. Como eficácia, quando se tem resultados sociais, ou seja, quando a população usufrui da água e dos serviços de esgoto, com nítida conseqüência em termos de abrangência dos serviços, incluindo um número cada vez maior de habitantes, tanto em termos de cobertura de água, como de coleta e tratamento de esgoto. Este foi o eixo para as discussões em relação a eficiência e eficácia nas gestões municipal e estadual dos serviços de água e esgoto nos Municípios de Campinas, Santo André, São José dos Campos e Santos. Por isso mesmo, não foram estabelecidos referenciais numéricos no sentido de medir quando uma gestão é mais eficaz que a outra, pois este não era o objetivo proposto; era, sim, o de analisar em que aspectos e em que âmbito de governo existem diferenças nessa eficiência e nessa eficácia da gestão daqueles serviços. Assim, a gestão enquanto ato de gerir e administrar, precisa integrar políticas públicas, políticas de governo bem como a eficiência e eficácia programadas.

Isto posto, necessário foi conhecer as formas de administração dos serviços públicos no Brasil, quais sejam: via direta, através dos próprios órgãos da administração pública ou, indiretamente, por meio de autarquias e entidades paraestatais, como sociedades de economia mista, empresas públicas e fundações. Assim, em relação aos serviços de abastecimento de água e esgotamento sanitário, estes vêm sendo administrados pelos Estados por meio 
de companhias, mediante concessões municipais; e pelos municípios, por meio de administração municipal direta, ou autarquias, ou empresas públicas ou ainda assistidos pela Fundação Nacional de Saúde. Desse modo, dos 5.507 municípios brasileiros (existentes até o ano de 2000) 1.700 administram esses serviços no âmbito municipal e os 3.807 municípios restantes são administrados pelas companhias estaduais.

Daí o desafio de conhecer e evidenciar as diferenças na eficiência e na eficácia da gestão desses serviços, no que se refere a esferas de governo e, no que se refere a existência de políticas públicas e políticas de governo, visando a contribuir para a área do saneamento e para o desenvolvimento da sociedade, através da saúde ambiental e da saúde humana. Para tanto, foram escolhidos municípios de grande porte pertencentes ao Estado de São Paulo, o qual tem 645 municípios, sendo que 366 têm a gestão dos serviços de água e esgoto no âmbito estadual e 279 no âmbito municipal. Com base em critérios pré-estabelecidos, foram selecionados dois municípios cuja responsabilidade da gestão é municipal e, dois municípios cuja responsabilidade da gestão é estadual, sendo respectivamente; Campinas e Santo André, São José dos Campos e Santos. Campinas conta com 966.700 habitantes e a gestão desses serviços é realizada pela SANASA - Sociedade de Abastecimento de Água e Saneamento S.A., empresa de economia mista, de capital aberto. Santo André conta com 648.121 habitantes tendo a gestão realizada pelo SEMASA Serviço Municipal de Saneamento Ambiental, autarquia municipal. São José dos Campos conta com 537.899 habitantes tendo a gestão de serviços sob a responsabilidade da SABESP - Companhia de Saneamento Básico do Estado de São Paulo, empresa de economia mista, capital aberto, concessionária de serviços municipais. Finalmente, Santos conta com uma população fixa de 417.771 habitantes e uma população flutuante em torno de 77.577 habitantes por ser uma cidade litorânea, tendo a gestão dos serviços de água e esgoto também, sob responsabilidade da SABESP.

Assim, ao discutir gestão do ponto de vista da integração das políticas publicas e de governo, partiu-se para o conhecimento de políticas públicas nos 
âmbitos nacional, estadual (São Paulo) e municipais, voltadas ao saneamento básico, num primeiro momento, e com estreita ligação aos serviços de água e esgoto num segundo momento. Quanto às políticas de governo, buscou-se conhecer naqueles municípios as políticas voltadas ao saneamento básico, ao longo do período de 1996 a 2000. Esta forma permitiu visualizar a integração dessas políticas públicas com as de governo, evidenciando aspectos na eficiência e na eficácia da gestão municipal e estadual.

Das políticas públicas estudadas, quais sejam, Constituição Federativa do Brasil de 1988, Política Nacional de Meio Ambiente de 1981, Política Nacional de Saúde de 1990, Política Nacional de Recursos Hídricos de 1997, Constituição do Estado de São Paulo de 1989, Política Estadual de Saneamento de 1992 e Política Estadual de Recursos Hídricos de 1991, depreenderam-se as observações abaixo.

Em relação a Constituição Federal há que se comentar o artigo 200, e em relação à Política Nacional da Saúde os artigos 6, 17 e 18, onde se indica que o Sistema Único de Saúde - SUS deverá participar da formulação da política e da execução das ações de saneamento básico. Pois bem, ao analisar os planos plurianuais e os orçamentos anuais dos 4 municípios pôde ser constatado que não existe uma integração das ações de saneamento básico com as de saúde, na medida em que nos orçamentos referentes às Secretarias Municipais de Saúde e daquelas com intervenções em saneamento básico não foram identificados programas e projetos integrados; pressupõe-se, então, que as ações entre saúde e saneamento ainda são tratadas de forma sensivelmente desarticulada, sendo que a área de saúde é bastante voltada às medidas preventivas e corretivas que contemplam a saúde do homem e muito menos as medidas preventivas voltadas ao saneamento do meio.

Já a Política Nacional de Meio Ambiente não traz uma diretriz específica ao saneamento básico; porém, contém diretrizes gerais visando à preservação da qualidade ambiental, que por sua vez estão intimamente ligadas às questões do saneamento e da saúde da população, cabendo aos gestores estabelecerem políticas de governo de forma a articulá-las e integrá-las. 
Quanto à Política Nacional de Recursos Hídricos, um dos pontos ressaltados é em relação ao instrumento - Planos de Recursos Hídricos que, segundo a lei, serão elaborados por bacia hidrográfica, por Estado e para o país. Eles têm como função básica orientar a implementação da Política Nacional de Recursos Hídricos. Os Planos Nacionais ainda não foram realizados. Por outro lado, a Política Estadual de Recursos Hídricos de São Paulo está bastante adiantada uma vez que o Plano Estadual foi implementado e já estão em andamento os Planos de Bacias Hidrográficas, que devem estabelecer diretrizes gerais, em nível regional, capazes de orientar os planos diretores municipais, notadamente o saneamento e a conservação dos recursos hídricos das bacias hidrográficas ou regiões hidrográficas correspondentes. Assim sendo, constatou-se que os municípios estudados vêm participando dos Comitês de Bacias buscando articulação e integração das políticas públicas e de governo, bem como lutando por investimentos para a gestão dos serviços de água e esgoto em suas respectivas Bacias Hidrográficas, por meio do Fundo Estadual de Recursos Hídricos.

No que tange a Constituição Estadual, artigo 216, fala-se que o Estado instituirá Plano Plurianual de Saneamento. A Companhia de Saneamento Básico realiza o seu Plano Plurianual de Investimentos, porém esse não foi disponibilizado para consulta, impossibilitando avançar as discussões sobre as diretrizes dos serviços de água e esgoto, referentes aos municípios de São José dos Campos e Santos, cuja responsabilidade da gestão é do governo estadual.

Em relação à Política de Saneamento Básico, Lei 7750 de 1992, fala-se do Plano Estadual de Saneamento que deve ser quadrienal, com base em Planos Regionais de Saneamento Ambiental, e encaminhado à Assembléia Legislativa para aprovação até o dia 30 de junho do primeiro ano de mandato do governador. Esse Plano é um instrumento necessário para o estabelecimento e implementação dos programas, projetos e atividades de saneamento, para dar visibilidade à gestão e auxiliar na integração das políticas públicas de recursos hídricos, meio ambiente e saúde. Desde a 
aprovação dessa lei, ou seja, dez anos, ainda não foi dado conhecimento do Plano Estadual de Saneamento, o que leva municípios a estabelecerem suas políticas públicas próprias que, muitas vezes, são desarticuladas das políticas públicas estaduais.

Percebe-se, então, que essas políticas públicas fazem menção de forma direta ou indireta ao Saneamento, cabendo aos gestores as articulações e integrações através de seus planos, programas e projetos, de forma a transformá-los em políticas públicas locais, integradas ao planejamento da cidade. Assim é que ao investigar os Planos Plurianuais, Leis de Diretrizes Orçamentárias, Leis Orçamentárias Anuais, Orçamentos Anuais e Planejamentos Estratégicos, e os resultados das políticas dos governos em cada município, foram evidenciadas questões como existência de integração entre o órgão gestor dos serviços de água e esgoto e o gestor da prefeitura como no caso de Campinas, Santo André e São José dos Campos, o que não foi evidenciado em Santos. Esse fato levou a concluir que, quando os gestores dos serviços de água e esgoto e os gestores da cidade compartilham dos mesmos ideais políticos, a eficiência e a eficácia em termos de gestão tendem a evoluir, pois contam com políticas públicas e políticas de governo articuladas visando dessa forma à universalização dos serviços. De forma contrária a esse exemplo, tem-se o Município de Santos, onde governo estadual e governo municipal não compartilham os mesmos ideais políticos, levando à políticas desarticuladas e com interesses difusos entre município e estado. Dentre os interesses difusos cita-se a prática de gestão desses serviços através de subsídios cruzados, que a Companhia Estadual estabelece, para subsidiar outros municípios atendidos pela Unidade de Negócios da Baixada Santista, considerados como deficitários. Esse é o interesse do gestor estadual pois, sendo o Município de Santos auto-suficiente em seus sistemas de água e esgoto, os investimentos nesse Município é somente para manutenção dos sistemas e atendimento ao crescimento vegetativo, sendo a maior parte dos investimentos direcionada para outros municípios. Este é um ponto de controvérsia entre governos estadual e local, na medida em que o gestor municipal tem interesse em investir em áreas ainda desprovidas desses 
sistemas. Portanto, quando o gestor da cidade e o gestor estadual dos serviços de água e esgoto compartilham com os mesmos ideais políticos a questão da eficiência e eficácia na gestão tendem a ações integradas no planejamento da cidade as diferenças fazem-se presentes positivamente, como é o caso de São José dos Campos.

Dentro desse contexto, e especialmente do cruzamento dos parâmetros adotados, quais sejam: Diretrizes das Leis Orgânicas e dos Planos Diretores com os Programas, Projetos, Atividades, Metas e Obras estabelecidos pelos governos, nos Planos Plurianuais, Leis de Diretrizes Orçamentárias, Leis Orçamentárias, Orçamentos Anuais e Planejamentos Estratégicos, é que se analisou cada um dos quatro municípios nos quesitos de eficiência e eficácia em relação aos aspectos de esgoto e de água.

No quesito eficiência, para o aspecto esgoto e água, a partir dos parâmetros cruzados, conclui-se que:

a gestão desses serviços em Campinas (municipal), Santo André (municipal) e São José dos Campos (estadual) mostrou-se eficiente. Já para o Município de Santos (estadual), a análise da eficiência mostrou-se comprometida. Por que? Primeiro, porque não foram encontradas, nos programas e projetos da Prefeitura de Santos, no período 1996-2000, evidências de articulação e integração nas políticas de governo entre gestores municipal e estadual. Segundo, porque os Planos Plurianuais do gestor estadual não foram disponibilizados, impossibilitando as conclusões para esse quesito. Portanto, sob este ponto de vista, o termo adotado pela pesquisadora para fins desta análise, foi: "sem aferição".

As tabelas 39 e 40 ilustram sinteticamente as conclusões aqui relatadas sobre o quesito eficiência para os aspectos de esgoto e de água, respectivamente.

Da análise realizada, conclui-se que as diferenças na eficiência da gestão estão calcadas na articulação e integração de políticas públicas e de políticas de governo; e não só, mas também na ausência de uma Política Nacional de Saneamento. 
Quanto ao quesito eficácia para os aspectos de esgoto e de água, a partir dos parâmetros cruzados, quais sejam; Diretrizes das Leis Orgânicas e dos Planos Diretores com os Programas, Projetos, Atividades, Metas e Obras estabelecidos pelos governos nos Planos Plurianuais, Leis de Diretrizes Orçamentárias, Leis Orçamentárias, Orçamentos Anuais e Planejamentos Estratégicos e com os Resultados alcançados de cada órgão gestor (dados quantitativos), conclui-se que:

No aspecto esgoto, para o índice de cobertura, os Municípios de Santo André (municipal) e São José dos Campos (estadual) mostraram-se eficazes. Campinas (municipal) mostrou-se menos eficaz e Santos (estadual), "sem aferição", pelos motivos expostos, ou seja: não foram encontradas evidências de articulação e integração nas políticas de governo entre gestores municipal e estadual, nos programas e projetos, no período 1996-2000; os Planos Plurianuais do gestor estadual não foram disponibilizados. Assim sendo, não foi possível fazer os cruzamentos a partir dos parâmetros adotados, pois uma análise pontual apenas com os resultados de políticas de governo de cada órgão gestor - dados quantitativos da tabela 29 - mascararia a metodologia adotada para esse trabalho.

Em relação ao índice de tratamento de esgoto, o Município de São José dos Campos também mostrou-se eficaz, enquanto o Município de Campinas mostrou-se ineficaz. Quanto ao Município de Santo André não foi aferido pois o tratamento é realizado pela SABESP; e por sua vez, em Santos, pelos motivos já expostos, também não foi possível aferir.

Para o aspecto esgoto no que tange à coleta, a gestão municipal mostrou-se eficaz para um município (Santo André) e ineficaz para outro (Campinas) e, a gestão estadual mostrou-se eficaz para um município (São José dos Campos) e "sem aferição" para outro (Santos). Já no aspecto esgoto, no que se refere ao índice de tratamento, a gestão estadual mostrou-se eficaz para um município (São José dos Campos) e "sem aferição" para outro (Santos); e a gestão municipal mostrou-se ineficaz para um municípios (Campinas) e "sem aferição" para o outro (Santo André). 
> Quanto ao aspecto água, a gestão municipal mostrou-se eficaz para os dois municípios (Campinas e Santo André) e a gestão estadual mostrou-se eficaz para um município (São José dos Campos) e "sem aferição" para o outro (Santos).

As tabelas 41 e 42 ilustram sinteticamente as conclusões aqui relatadas sobre o quesito eficácia para os aspectos de esgoto e de água, respectivamente.

Do estudo realizado, depreende-se que não basta ter somente políticas públicas e de governo articuladas e integradas, mas, também, que elas sejam avaliadas num processo contínuo para aferir a eficácia dos serviços prestados, mediante confrontação com indicadores sociais. Elementos necessários para aferir a eficácia são, ainda, a participação crescente da população nos mecanismos de implementação de políticas públicas.

Para os usuários não importa se a gestão é municipal ou estadual, se é pública ou até mesmo com a participação da iniciativa privada; interessa, sim, se essa gestão possibilita água com qualidade, quantidade e universalidade. Importa, sim, se essa gestão possibilita que seus esgotos sejam coletados, afastados e tratados garantindo saúde ambiental e humana. Importa também, e principalmente, se essa gestão oferece serviços capazes de atender às necessidades básicas da comunidade, em forma sustentável e de molde a impulsionar o processo de desenvolvimento econômico-social.

Por fim, um dos caminhos para solucionar essa questão institucional é a implementação de uma Política Nacional de Regulação desse serviços, definindo-se as responsabilidades de cada um dos níveis de governo de maneira que a regulação e o controle sejam atribuídos ao nível nacional, ficando a prestação dos serviços, a cargo do nível local, direta ou indiretamente, público ou público-privado, concedidas ou não. Assim sendo, a forma institucional é relativa, não importando se estadual ou municipal; o que importa é que toda essa política seja conduzida a luz dos princípios constitucionais e legais. Mas, não só; também é importante contextualizar todo 
este trabalho no quadro da gestão ambiental moderna, segundo a qual eficiência e eficácia se subordinarão aos três requisitos seguintes: que o processo seja economicamente viável; socialmente eqüitativo e ecologicamente prudente. 


\section{Referências}

\subsection{Citadas}

ALVES-MAZZOTTI E GEWANDSZNAJDE. O método nas Ciências naturais e Sociais. Pesquisa Quantitativa e Qualitativa. 2a ed. São Paulo (SP): Pioneira,1999.

ANONYMUS. Revista Brasileira de Saneamento e Meio Ambiente-BIO; 1990; n.9:34-35.

ASSEMAE-Associação Nacional dos Serviços Municipais de Saneamento Foco no Município. Disponível na página <URL: http://www.asbyte.com.br/assemae $>$ [2000a Abril14].

ASSEMAE-Associação Nacional dos Serviços Municipais de Saneamento. Relação dos municípios associados à Assemae na categoria de serviço municipal de água e esgoto. Jaboticabal: 2000 b.[material encaminhado via internet pela Associação].

Banco Mundial. A agenda ambiental marrom - Brasil: Gestão dos problemas da poluição - Relatório de Política. Brasil;1998.

Barros RLF. Mudanças na administração municipal (1988 - 1997): uma análise dos suportes institucionais de práticas locais selecionadas. São Paulo; 1999. [Dissertação de Mestrado - Fundação Getúlio Vargas].

Bau J A. Exceções a regra: os modelos inglês e francês. Revista Água e Vida. 1996 a; 6: 28-31.

Bau J A. Regra é o público e local. Revista Água e Vida. 1996 b; 6: 24-27.

BNDES-Banco Nacional de Desenvolvimento Social. Setor de saneamento Rumos adotados. Informe infra-estrutura. 1998; 20: Disponível na página <URL: http://www.bndes.gov.br>[2001 Ago 02].

BNH-Banco Nacional da Habitação. Relatório sobre o desenvolvimento do Planasa. São Paulo (SP): 1975.

Brasil. Constituição Federativa do Brasil. $3^{\mathrm{a}}$ ed. Rio de Janeiro: DP\&A; 1999.

Brasil. Mensagem nº4. Veta o Projeto de Lei 199 de 1993 que Dispõe sobre a Política Nacional de Saneamento, seus instrumentos e dá outras providências. D.O.U - Diário Oficial da República Federativa, Brasília, 05 jan 1995. Seção I, p.274.

Brasil. Lei n. 6.938, de 31 de agosto de 1981. Dispõe sobre a política nacional do meio ambiente. Disponível na página <URL: http://www.mma.gov.br>[2000].

Brasil. Lei n. 9.433, de 8 de janeiro de 1997. Institui a política nacional de recursos hídricos, cria o sistema nacional de recursos hídricos, Legislação sobre recursos hídricos. Governo do Estado de São Paulo / DAEEDepartamento de águas e energia elétrica. São Paulo, julho 2000. p.1-13. 
Brasil. Lei n. 9.984, de 17 de julho de 2000. Dispõe sobre a criação da agência nacional de água. Disponível na página <URL: http://www. www.aguaonline.com.br > [2001 Jun 19].

Brasil. Projeto de Lei 4.147 de 2001. Institui diretrizes nacionais para o saneamento básico. Disponível na página <URL: http://www.aguaonline.com.br> [2001].

Brasil. Lei n. 8.080, de 19 de setembro de 1990. Dispõe sobre condições para a promoção e proteção e recuperação da saúde, a organização e o funcionamento dos serviços correspondentes. Disponível na página <URL: http://www.saude.gov.br> [2002 Maio 14].

Campinas. Lei n.7.762, de 30 de dezembro de 1993. Estabelece o plano plurianual do município de Campinas para o quadriênio 94/97. DOM - Diário oficial municipal $31 \mathrm{dez} 1993$.

Campinas. Lei n.8.441, de 28 de julho de 1995. Dispõe sobre as diretrizes orçamentárias do exercício de 1996. DOM - Diário oficial municipal 29 julho 1995a.

Campinas. Lei n.8.730, de 29 de dezembro de 1995. Orçamento-programa do município de Campinas para o exercício de 1996. DOM - Diário oficial municipal 30 dez 1995b.

Campinas. Lei n. 8.905, de 29 de julho de 1996. Dispõe sobre as diretrizes orçamentárias do exercício de 1997. DOM - Diário oficial municipal 30 julho 1996a.

Campinas. Lei n. 9.201, de 30 de dezembro de 1996. Dispõe sobre o orçamento programa do município de Campinas para o exercício de 1997. DOM - Diário oficial municipal $31 \mathrm{dez} 1996 \mathrm{~b}$.

Campinas. Lei n. 9.341, de 01 de agosto de 1997. Dispõe sobre as diretrizes para a elaboração orçamentária do exercício de 1998. DOM - Diário oficial municipal 02 ago 1997a.

Campinas. Lei n. 9.583, de 23 de dezembro de 1997. Estabelece o plano plurianual do município de Campinas para o quadriênio 1998/2001. DOM Diário oficial municipal 24 dez 1997b.

Campinas. Lei n. 9.588, de 29 de dezembro de 1997. Dispõe sobre o orçamento programa do município de Campinas para o exercício de 1998. DOM - Diário oficial municipal 31 dez $1997 \mathrm{c}$.

Campinas. Lei n. 9.805, de 21 de julho de 1998. Dispõe sobre as diretrizes para a elaboração da lei orçamentária de 1999. DOM - Diário oficial municipal 22 julho 1998a.

Campinas. Lei n. 9.972, de 29 de dezembro de 1998. Dispõe sobre o orçamento programa do município de Campinas para o exercício de 1999. DOM - Diário oficial municipal 31 dez 1998b.

Campinas. Lei n. 10.186, de 28 de julho de 1999. Dispõe sobre as diretrizes para a elaboração da lei orçamentária de 2000. DOM - Diário oficial municipal 29 julho 1999a. 
Campinas. Lei n. 10.402, de 30 de dezembro de 1999. Dispõe sobre o orçamento programa do município de Campinas para o exercício de 2000. DOM - Diário oficial municipal 31 dez 1999b.

Campinas. Lei Orgânica. 1990. Disponível na página <URL: http://www.campinas.sp.gov.br] [2001].

Carneiro JMB. Responsabilidade local e desafio regional: relações intergovernamentais na gestão de recursos hídricos. São Paulo; 1994. [Dissertação de Mestrado - Fundação Getúlio Vargas].

Cavalcanti JC. A Reforma do sistema financeiro do saneamento elementos para uma discussão.[ mineo/ São Paulo].

CEF-Caixa Econômica Federal. Norma para estruturação de regulação da parceria público-privada na prestação de serviços de abastecimento de água e esgotamento sanitário. s.d.p..

CNS-Conferência Nacional de Saneamento -Comissão de Desenvolvimento Urbano e Interior da Câmara Federal - Subcomissão de Saneamento. Relatório síntese da conferência nacional de saneamento. Brasília (DF); 1999.

DAE-Departamento de Água e Esgotos de Campinas. Plano diretor de esgotos sanitários. Campinas (SP); 1972.

EMPLASA-Empresa metropolitana de planejamento da grande São Paulo. Região metropolitana de Campinas. Disponível na página <URL: http://www.emplasa.sp.gov.br $>$ [2001 Out 06].

Fernández - Giraldo D. La Intervencíon estatal en los servicios de agua potable y saneamiento. 1996; Bogotá (DC). p. 16-28.

Fischer T. Poder local: um tema em análise. In: Fischer T. Poder local: governo e cidadania. Rio de Janeiro:(RJ); 1993. p.10-20.

FUNASA - Fundação Nacional de Saúde; ASSEMAE - Associação Nacional dos Serviços Municipais de Saneamento - Diagnóstico Nacional dos serviços municipais de saneamento. Brasília - $2^{\mathrm{a}}$ ed. (DF); 1996.

Gazeta Mercantil. Análise setorial - saneamento básico. Panorama setorial; 1998. v.1.

GIL AC. Como elaborar projetos de pesquisa. $3^{a}$ ed. São Paulo (SP): Atlas, 1997.

GIL AC. Métodos e técnicas de pesquisa social. $4^{a}$ ed. São Paulo (SP): Atlas, 1995.

Hogan DJ, Cunha JMP da, Baeninger R, Carmo RL do (org.). Migração e ambiente em São Paulo-Aspectos relevantes da dinâmica recente. Campinas: NEPAM - UNICAMP; 2000.

IBAM - Instituto Brasileiro de Administração Municipal. Administração para os serviços de abastecimento d' agua. Rio de Janeiro (RJ): IBAM,1967. 
IBAM - Instituto Brasileiro de Administração Municipal. Consulta nacional sobre a gestão do saneamento e do meio ambiente urbano. Brasília (DF); 1994.

IBGE - Instituto Brasileiro de Geografia e Estatística. Contagem da população-1996. Disponível na página <URL: http://www.ibge.gov.br. >[2000 Abril 24].

IBGE - Instituto Brasileiro de Geografia e Estatística. Pesquisa de informações básicas municipais: 1999. São Paulo. Disponível na página <URL: http://www.ibge.gov.br >[2001 Ago 17].

IBGE - Instituto Brasileiro de Geografia e Estatística. Sinopse preliminar do Censo 2000. Disponível na página em <URL: http://www.ibge.gov.br. >[2002 ].

Idelovitch E, Ringskog K. Private Sector in Water Suply and Sanitation in Latin America. Washington, DC: World Bank; 1995.

Jorge W.E. A Política nacional de saneamento pós-64. São Paulo;1987. [Tese de Doutorado - Faculdade de Arquitetura e Urbanismo da USP].

KOCHE JC. Fundamentos de Metodologia Científica: Teoria da ciência e prática da pesquisa. 15a ed. São Paulo (SP): Vozes, 1999.

Lesouef A. Water Science Technology. Institutions and water management efficiency: the art of equilibrium. 1996; 34(12).

Levy E. O impacto da democratização nas organizações públicas locais. In: Tânia Fischer. O poder local. Rio de Janeiro (RJ): FGV; 1993, p. 89-93.

Lima F. Gestão Ambiental e Recursos Hídricos. In: Manual de Gestão do Seminário Técnico sobre a gestão de serviços de saneamento; 1999 agosto; Rio de Janeiro, Brasil. Rio de Janeiro: ABES-RJ; 2000. p.I-3 a I-47

Michaelis. Dicionário da língua portuguesa. Disponível na página <URL: http://www.uol.com.br/michaelis >[2002 ].

Ministério do Interior. Banco Nacional da Habitação. Relatório sobre o desenvolvimento do Planasa - Plano Nacional do Saneamento. São Paulo. (SP); 1975.

MPO-Ministério do Planejamento e Orçamento. Secretaria de Política Urbana. Série Modernização do Setor Saneamento. Fundamentos e proposta de ordenamento institucional - Volume 1. Brasília (DF); 1995.

MPO-Ministério do Planejamento e Orçamento. Secretaria de Política Urbana. Série Modernização do Setor Saneamento - Diagnóstico do setor: Saneamento: estudo. econômico e financeiro - volume 7: Brasília (DF); 1995.

MTE - Ministério do Trabalho e Emprego. Fundo de garantia do tempo de serviço. Disponível na página <URL: http://www.mte.gov.br >[2002].

Neder RT. O problema da regulação pública ambiental no Brasil - três casos. In: Ferreira LC, Viola E, Orgs. Incertezas da Sustentabilidade na Globalização. Editora UNICAMP: Campinas: São Paulo, 1996. p.217-239. 
Pegoraro LS. Origem e evolução do saneamento básico no Estado de São Paulo. Revista DAE. 1986; 46: 372-379.

Peixoto JB. O barulho da água - os municípios e a gestão dos serviços de saneamento. São Paulo (SP): Parma; 1994.

Petry J. The french approach of involving the private sector in water and waste water management - Water Suply 1997; 15 (1).

Philippi Jr. A, Bruna GC. Política e Gestão Ambiental. São Paulo. 2002. [Apostila do Curso de Especialização em Gestão Ambiental - Núcleo de Informações em Saúde Ambiental da Faculdade de Saúde Pública da USP].

PMC-Prefeitura Municipal de Campinas. Campinas novo século. Estratégias para o desenvolvimento. Campinas (SP); 1996.

PMC-Prefeitura Municipal de Campinas. Informações gerais sobre Campinas. Disponível na página <URL: http://www.campinet.spgov.br. $>$ [2001 Jul 11].

PMC-Prefeitura Municipal de Campinas. Plano Diretor. Campinas (SP); 1995.

PMSA-Prefeitura Municipal de Santo André. Cenário para um Futuro Desejado-Cidade Futuro - Semasa. 2001a.

PMSA-Prefeitura Municipal de Santo André. Cidade Futuro. Disponível na página <URL: http://www.santoandre.sp.gov.br [2001c Abril 20].

PMSA-Prefeitura Municipal de Santo André. Relatório geral de metas -cidade futuro/Semasa. $2001 \mathrm{~b}$.

PMSA-Prefeitura Municipal de Santo André. Sumário de Dados de Santo André. Santo André(SP); 1996.

PMSJC-Prefeitura Municipal de São José dos Campos. São José em Dados 2000. Disponível em <URL:http://www.sjc.sp.gov.br> [2001 Jun 26].

PNQS - Prêmio Nacional da Qualidade em Saneamento. Guia PNQS. ABES Associação Brasileira de Engenharia Sanitária e Ambiental. Disponível na página <URL:http://www.pnqs.com.br/indicadores>[2001].

PNSB - Pesquisa Nacional de Saneamento Básico 2000. IBGE/ Departamento de População e Indicadores Sociais. Rio de Janeiro; IBGE, 2002.

Rezende F. Possibilidades de descentralização e privatização de serviços de saneamento no Brasil. In: Seminário Internacional de Descentralização e Privatização do Serviço de Saneamento; 1994 jun 15-17. Brasília (DF). p.143-149.

Rudio FV. Introdução ao projeto de pesquisa científica. $25^{a}$ ed. Petrópolis (RJ): Vozes; 1999.

SABESP. Companhia de Saneamento Básico do Estado de São Paulo. Balanço Social 1995-1998. São Paulo (SP) 2002.

SABESP-Companhia de Saneamento Básico de São Paulo. Conferência Nacional de Saneamento - Relatório Síntese. São Paulo. Ligação 2000; n.7. 
SANASA-Sociedade de abastecimento de água e saneamento S/A histórico da sanasa e palácio dos azulejos. Campinas (SP); s.d.p.

SANASA-Sociedade de abastecimento de água e saneamento S/A Plano diretor de água de Campinas. Campinas (SP); 1992.

SANASA-Sociedade de abastecimento de água e saneamento S/A. Plano Estratégico da Sanasa (1994-2004). Relatório final. Campinas(SP); 1994.

SANASA-Sociedade de abastecimento de água e saneamento S/A. 0 planejamento estratégico da SANASA. Campinas (SP); 1996.

SANASA-Sociedade de abastecimento de água e saneamento S/A. Relatório da Administração. D.O.E-Diário Oficial do Estado; Empresarial. 23 de abril de 1997. Seção 107 (76) p.45-46.

SANASA-Sociedade de abastecimento de água e saneamento S/A. Relatório da Administração. D.O.E-Diário Oficial do Estado; Empresarial. 19 de março de 1998. Seção 108 (53), p.4-6.

SANASA-Sociedade de abastecimento de água e saneamento S/A. Relatório da Administração. D.O.E-Diário Oficial do Estado; Empresarial. 20 de março de 1999. Seção 109 (52), p.5-8.

SANASA-Sociedade de abastecimento de água e saneamento S/A. Relatório da Administração. D.O.E-Diário Oficial do Estado; Empresarial. 21 de março de 2000. Seção 110 (54), p.3-6.

SANASA-Sociedade de abastecimento de água e saneamento S/A. Relatório da Administração. D.O.E-Diário Oficial do Estado; Empresarial. 29 de março de 2001a. Seção 111 (59), p.97-99.

SANASA-Sociedade de abastecimento de água e saneamento S/A História e Sanasa hoje. Disponível na página <URL: http://www.sanasa.com.br. $>$ [2001b Jul 17].

Santo André. Lei n. 7.102, de 27 de dezembro de 1993. Dispõe sobre o plano plurianual do município de Santo André, para o período de 1994 a 1997. DOM - Diário oficial do Município 1993.

Santo André. Lei n. 7.268, de 07 de junho de 1995. Estabelece as diretrizes gerais para a elaboração da lei orçamentária do Município de Santo André, relativo ao exercício de 1996. DOM - Diário Oficial do Município 1995a.

Santo André. Lei n. 7.334, de 26 de dezembro de 1995. Estabelece o orçamento geral do município de Santo André, para o exercício de 1996. DOM - DOM - Diário oficial do município 1995b.

Santo André. Lei n. 7.390, de 26 de junho de 1996. Referente ao projeto de saneamento do plano plurianual 1994-1997. DOM - Diário oficial do município 1996a.

Santo André. Lei n. 7.382, de 11 de junho de 1996. Estabelece as diretrizes gerais para a elaboração da lei orçamentária do município de Santo André, relativa ao exercício de 1997. DOM - Diário oficial do município 1996b. 
Santo André. Lei n. 7.464, de 08 de dezembro de 1996. Estabelece o orçamento geral do município de Santo André, para o exercício de 1997. DOM - Diário oficial do município 1996c.

Santo André. Lei n. 7.482, de 03 de junho de 1997. Estabelece as diretrizes gerais para a elaboração da lei orçamentária do município de Santo André, relativa ao exercício de 1998. DOM - Diário oficial do município 1997a.

Santo André. Lei n. 7.584, de 10 de dezembro de 1997. Dispõe sobre o plano plurianual do município de Santo André, para o período de 1998 a 2001 . DOM - Diário oficial do município $1997 b$.

Santo André. Lei n. 7.589, de 15 de dezembro de 1997. Estabelece o orçamento geral do município de Santo André, para o exercício de 1998. DOM - Diário oficial do município 1997c.

Santo André. Lei n. 7.688, de 06 de julho de 1998. Estabelece diretrizes para a elaboração da lei orçamentária. DOM - Diário oficial do município 1998a.

Santo André. Lei n. 7.769, de 30 de dezembro de 1998. Dispõe sobre o orçamento geral do município de Santo André para o exercício de 1999. DOM Diário oficial do município 1998 b.

Santo André. Lei n. 7.870, de 20 de julho de 1999. Dispõe sobre diretrizes gerais para a elaboração da lei orçamentária do município de Santo André, para o exercício de 2000. DOM - Diário oficial do município 1999a.

Santo André. Lei n. 7.941, de 07 de dezembro de 1999. Dispõe sobre o orçamento geral do município de Santo André, para o exercício de 2000. DOM - Diário oficial do município $1999 b$.

Santo André. Lei n. 7.733, de 14 de outubro de 1998. Dispõe sobre a política municipal de gestão e saneamento ambiental. Disponível na página <URL: http://www.santoandre.sp.gov.br [2000].

Santo André. Lei Orgânica Municipal. 1990 Disponível na página <URL: http://www.cmsandre.sp.gov.br> [2001a Jun 18].

Santo André. Lei n. 7.333, de 26 de dezembro de 1995. Plano diretor. Disponível na página <URL: http://www.cmsandre.sp.gov.br> [2001b Nov 11].

Santos. Lei n. 1.282, de 01 de dezembro de 1993. Dispõe sobre o plano plurianual do município de Santos para o período de 1994 a 1997. Secretaria Municipal de Economia e Finanças.DOM-Diário oficial do município 1993.

Santos. Lei n. 1.439, de 01 de dezembro de 1995. Dispõe sobre a receita e fixa a despesa do município de Santos para o exercício financeiro de 1996. Secretaria Municipal de Economia e Finanças. DOM - Diário oficial do município 1995.

Santos. Dispõe sobre as diretrizes orçamentárias de 1996. Secretaria Municipal de Economia e Finanças. DOM - Diário oficial do município 1996a.

Santos. Lei n. 1.536, de 10 de dezembro de 1996. Dispõe sobre a receita e fixa a despesa do município de santos para o exercício financeiro de 1997. 
Secretaria Municipal de Economia e Finanças. DOM - Diário oficial do município $1996 b$.

Santos. Lei n. 1.508, de 15 de julho de 1996. Dispõe sobre as diretrizes orçamentárias para o exercício de 1997. Secretaria Municipal de Economia e Finanças. DOM - Diário oficial do município 1996c.

Santos. Lei n. 1.643, de 08 de dezembro de 1997. Dispõe sobre o plano plurianual do município de Santos para o exercício de 1998 a 2001. Secretaria Municipal de Economia e Finanças. DOM - Diário oficial do município 1997a.

Santos. Lei n. 1.642, de 08 de dezembro de 1997. Dispõe sobre a receita e fixa a despesa do município de Santos para o exercício financeiro de 1998 Secretaria Municipal de Economia e Finanças. DOM - Diário oficial do município 1997b.

Santos. Dispõe sobre as diretrizes orçamentárias de 1998 - Secretaria Municipal de Economia e Finanças. DOM - Diário oficial do município 1997c.

Santos. Lei Complementar n. 311, de 23 de novembro de 1998. Institui o plano diretor de desenvolvimento e expansão urbana do município de Santos. DOM Diário oficial do município 1998a.

Santos. Lei n. 1.710 de 11 de dezembro de 1998. Dispõe sobre a receita e fixa a despesa do município de Santos para o exercício financeiro de 1999. Secretaria Municipal de Economia e Finanças. DOM - Diário oficial do município 1998b.

Santos. Dispõe sobre as diretrizes orçamentárias de 1999. Secretaria Municipal de Economia e Finanças. DOM - Diário oficial do município 1998c.

Santos. Lei n. 1.827, de 20 de dezembro de 1999. Dispõe sobre a receita e fixa a despesa do município de Santos para o exercício de 2000. Secretaria Municipal de Economia e Finanças. DOM - Diário oficial do município 1999a.

Santos. Dispõe sobre as diretrizes orçamentárias de 2000. Secretaria Municipal de Economia e Finanças. DOM - Diário oficial do município $1999 \mathrm{~b}$.

Santos. Lei Orgânica. 1990. Disponível na página <URL: http://www.unisantos.br> [2001].

São José dos Campos. Lei n. 4.532, de 28 de dezembro de 1993. Dispõe sobre o plano plurianual do município de São José dos Campos para o período de 1994 a 1997. Secretaria Municipal de Economia e Finanças. DOM - Diário oficial do município 1993.

São José dos Campos. Lei n. 4.728, de 21 de julho de 1995. Dispõe sobre as diretrizes orçamentárias - exercício de 1996. Secretaria Municipal de Economia e Finanças. DOM - Diário oficial do município 1995a.

São José dos Campos. Lei n. 4.906, de 30 de julho de 1995. Dispõe sobre diretrizes orçamentárias - exercício 1997. Secretaria Municipal de Economia e Finanças. DOM - Diário oficial do município 1995b.

São José dos Campos. Lei n. 4.790, de 18 de janeiro de 1996. Dispõe sobre a receita e fixa a despesa do município de São José dos Campos, para o 
exercício de 1996. Secretaria Municipal de Economia e Finanças. DOM Diário oficial do município 1996a

São José dos Campos. Lei n. 5.003, de 27 de dezembro de 1996. Dispõe sobre a receita e fixa a despesa do município de São José dos Campos, para o exercício de 1997. Secretaria Municipal de Economia e Finanças. DOM Diário oficial do município 1996b.

São José dos Campos. Lei n. 5.070, de 11 de julho de 1997. Dispõe sobre diretrizes orçamentárias- exercício de 1998. Secretaria Municipal de Economia e Finanças. DOM - Diário oficial do município 1997a

São José dos Campos. Lei n. 5.137, de 29 de dezembro de 1997. Dispõe sobre a receita e fixa a despesa do município de São José dos Campos, para o exercício de 1998. Secretaria Municipal de Economia e Finanças. DOM Diário oficial do município 1997b.

São José dos Campos. Lei n. 5.138, de 29 de dezembro de 1997. Dispõe sobre o plano plurianual de investimentos do município de São José dos Campos para o período de 1998 a 2001. Secretaria Municipal de Economia e Finanças. DOM - Diário oficial do município 1997c.

São José dos Campos. Lei n. 5.249, de 23 de julho de 1998. Dispõe sobre diretrizes orçamentárias-exercício de 1999. Secretaria Municipal de Economia e Finanças. DOM - Diário oficial do município 1998a.

São José dos Campos. Lei n. 5.307, de 29 de dezembro de 1998. Dispõe sobre a receita e fixa a despesa do município de São José dos Campos, para o exercício de 1999. Secretaria Municipal de Economia e Finanças. DOM Diário oficial do município $1998 b$.

São José dos Campos. Lei n. 5.549, de 20 de dezembro de 1999. Altera a redação da Lei n. 5.538, de 08 de dezembro de 1999, que estima a receita e fixa a despesa do município de São José dos Campos, para o exercício de 2000. Secretaria Municipal de Economia e Finanças. DOM - Diário oficial do município 1999a.

São José dos Campos. Lei n. 5.413, de julho de 1999. Dispõe sobre as diretrizes orçamentárias para o exercício de 2000. Secretaria Municipal de Economia e Finanças. DOM - Diário oficial do município $1999 b$.

São José dos Campos. Lei Orgânica. 1990. Disponível na página <URL: http://wwwsjc.sp.gov.br> [2001].

São Paulo (Estado). Proposta de Projeto de Lei Federal. Instituindo a Política Federal de Saneamento. São Paulo, junho 1990. [Resultante do Seminário "Renovação e Desenvolvimento do Saneamento do País" - Instituto de Engenharia em maio de 1990].

São Paulo. Lei n. 7.750, de 31 de março de 1992. Dispõe sobre a política estadual de saneamento. Associação brasileira de engenharia sanitária e ambiental. A nova legislação do saneamento paulista, São Paulo, junho 1992. 
São Paulo (Estado). Manual Básico - Indicador de Salubridade Ambiental ISA. Secretaria de Recursos Hídricos, Saneamento e Obras. São Paulo; 1999.

São Paulo (Estado). Constituição do Estado de São Paulo. São Paulo: 1989 Disponível na página <URL: http://www.al.sp.gov.br>. [2001].

São Paulo (Estado). Lei n. 7.663, de 30 de dezembro de 1991. Estabelece normas de orientação à política estadual de recursos hídricos. Disponível na página <URL: http://www.recursoshidricos.sp.gov.br> [2002 Fev 17].

SEADE - Fundação Sistema Estadual de Análise de Dados. Informações Básicas Municipais. Disponível na página <URL: http://www.seade.gov.br> [1999].

Semasa-Serviço Municipal de Saneamento Ambiental. Relatório de Atividades do exercício de 1996. Santo André (SP); 1997a.

Semasa-Serviço Municipal de Saneamento Ambiental de Santo André. Seminário de implantação do planejamento estratégico. Santo André (SP); 1997b.

Semasa-Serviço Municipal de Saneamento Ambiental. Relatório de Atividades do exercício de 1997. Santo André (SP) ; 1998.

Semasa-Serviço Municipal de Saneamento Ambiental. Relatório de Atividades do exercício de 1998. Santo André (SP); 1999.

Semasa-Serviço Municipal de Saneamento Ambiental. Relatório de Atividades do exercício de 1999. Santo André (SP); 2000.

Senado Federal. PLS 266 de 05 de Dezembro de 1996. Disponível na página <URL: http://www.legis.senado.gov.br> [2002 Jul 22].

Serva M. Gestão urbana e qualidade de vida. In: Tânia Fischer. O poder local. Rio de Janeiro (RJ): FGV; 1993, p.203-208.

Severino AJ. Metodologia do trabalho científico. $20^{a}$ ed. São Paulo (SP): Cortez; 1999.

Simões NM. Um novo modelo de gestão do saneamento. A gestão participativa. São Paulo, 1998.

Singer P. O Brasil no contexto do capitalismo internacional: 1889 - 1930 in Revista Mexicana da Sociologia.1974; julho / setembro.

SNIS-Sistema Nacional de Informações em Saneamento. Diagnóstico nacional dos serviços de água e esgoto-1996. SEDU/ IPEA: Brasília (DF); 1997.

SNIS-Sistema Nacional de Informações em Saneamento. Diagnóstico nacional dos serviços de água e esgoto-1997. SEDU/ IPEA: Brasília (DF); 1998.

SNIS-Sistema Nacional de Informações em Saneamento. Diagnóstico nacional dos serviços de água e esgoto-1998. SEDU/ IPEA: Brasília (DF); 1999. 
SNIS-Sistema Nacional de Informações em Saneamento. Diagnóstico nacional dos serviços de água e esgoto-1999. SEDU/ IPEA: Brasília (DF); 2000.

Teixeira JC, Heller L. Modelo de priorização de investimentos em saneamento com ênfase em indicadores de saúde: desenvolvimento e aplicação em uma companhia estadual. Eng. Sanit. e Ambiental. 2001; 6:138-146.

Tenório FG (org.) Gestão de ONG's: principais funções gerenciais. Rio de Janeiro: FGV, 1997.

Thiollent M. Metodologia da pesquisa-ação. $6^{a}$ ed. São Paulo (SP): Cortez, 1994.

Vergara SC. Sugestão para estruturação de um projeto de pesquisa. Rio de Janeiro. (RJ). Fundação Getúlio Vargas. Escola Brasileira de Administração Pública. Departamento de Pesquisa e Publicações. 1990. (Cadernos de Pesquisa 02/91).

Wald A. PROMUDE - Programa Municipal de Desestatização - Prefeitura do Município de São Paulo - Secretaria dos Negócios Jurídicos. [Processo 20000.165.402-7 / parecer técnico a respeito do saneamento básico] 2000.

WHO-World Health Organization and United Nations Children's Fund. Water Suply and Sanitation Assesment. 2000.

\subsection{Consultadas}

Abreu MT. A escassez de água para o abastecimento público e a influência da degradação ambiental. estudo de caso: represas billings e guarapiranga. São Paulo; 1999. [Dissertação de Mestrado - Universidade Presbiteriana Mackenzie].

Aguas argentinas S.A. Marcha de la concesión de los servicios de agua y cloacas en el aglomerado bonaerense. Ingenieria Sanitaria y Ambiental. 1994; (17): 28-30.

Amaral e Silva CC. Importância do saneamento do meio ambiente no disciplinamento do uso e da ocupação do solo. São Paulo; 1987 [Tese de livre docência - FSP/USP].

Ancell M. Privatization of public facilities: panacea or pipe dream ? Enviromental Protection Agency. 1993. 4p.

Arner R. Privatization of municipal waste management services in Virgínia. Waste Age.1994; 25(7): 54-60.

Associação Nacional dos Serviços Municipais de Saneamento - Assemae. Saneamento e Municípios. Jornal da Assemae 2000; nº 87 e 88.

Bento AM, Ferreira MRD. A prática da pesquisa em ciência social: uma estratégia de decisão e ação. Rio de Janeiro; 1982. Relatório Técnico $\mathrm{n}^{\circ} .54$. COPPEAD/UFRJ. 
Brasil. Lei n. 5.318, de 26 de setembro de 1967. Institui a Política Nacional de Saneamento e cria o conselho nacional de saneamento.

Caetano JRG, Oliveira GP. A construção de uma política pública de gestão ambiental: o caso de Santo André. In: 20 ${ }^{\circ}$ Congresso Brasileiro de Engenharia Sanitária e Ambiental; 1999 maio; Rio de Janeiro (RJ); ABES;1999.

Caffé AA. Saneamento Básico: concessões, permissões e convênios. São Paulo (SP): EDIPRO, 1998.

Carmignani $A$. Presidente da Sabesp manda $A B C$ ir à justiça. Diário do grande $A B C, 2000,03,22$; Política ABC:04 (Notícias/Secretaria de Estado do Meio Ambiente-SISEMA).

CEPAM - Fundação Prefeito Faria Lima. O município no século XXI: cenários e perspectivas. São Paulo (SP): CEPAM, 1999.

Chaves APL. Temática ambiental e queixas: Uma cidadania do cotidiano. São Paulo; 1998. [Tese de Doutorado - Faculdade de Saúde Pública da USP].

Coimbra JAA. O outro lado do meio ambiente. Campinas (SP): Millennium, 2002.

Conforto G. Descentralização e regulação da gestão de serviços públicos. Revista de Administração Pública. 1998; 32(1): 27-40.

Cunha JA. Sustentabilidade e poder local: a experiência política ambiental em São Sebastião; São Paulo; 1996. [Tese de Doutorado- Faculdade de Saúde Pública da USP].

Dawbor L, Ianni O, Resende PEA, Orgs. Desafios da Globalização. $2^{a}$ ed. São Paulo: Vozes; 1997.

Empresa Metropolitana de Planejamento da Grande São Paulo - EMPLASA. Criação e implantação de um sistema de indicadores ambientais e de qualidade de vida. São Paulo (SP); 1993.

Ferraz ARG. Modelo decisório para a outorga de direito ao uso da água no estado de São Paulo. São Paulo, 1996. [Dissertação de Mestrado. Escola Politécnica da USP].

Ferreira LC. A busca de alternativas de sustentabilidade no poder local. In: Ferreira LC, Viola E, Orgs. Incertezas da Sustentabilidade na Globalização. Editora UNICAMP. Campinas: São Paulo; 1996. p.133-160

Ferreira LC. A questão ambiental. Sustentabilidade e políticas públicas no Brasil. São Paulo (SP): Boitempo; 1998.

Fonseca JP. Poder local e municipalização. São Paulo; 1995. [Tese de livre docência - FE/USP].

Gabriel R. The Private provision of public services in developing countries. New York: Oxford University Press; 1987. 
Gandin D. A prática do planejamento participativo: na escola e em outras instituições, grupos e movimentos dos campos cultural, social, político, religioso e governamental. Petrópolis (RJ): Vozes; 1995. São Paulo.

Hervas Martin JL. Desempenõ de la empresa de aguas de Murcia: su transformación en una empresa de economía mixta. In: Ministerio de Desarrollo Económico; PNUD; Banco Mundial. Economía del y sector privado. Bogotá: Banco Mundial; 1996. p.199-207.

Huertas F. Entrevista com Carlos Matus: o Método PES. São Paulo: Fundap, 1996.

Jacobi P. Alcances e limites de governos locais progressistas no Brasil: as prefeituras petistas. Cadernos CEDEC, São Paulo, $n^{\circ} 34$.

Jacobi PR. A percepção dos problemas ambientais urbanos em São Paulo. In: Ferreira LC, Viola E, Orgs. Incertezas da Sustentabilidade na Globalização. Editora UNICAMP: Campinas: São Paulo, 1996. p.177-188.

Jacobi PR. Políticas públicas de saneamento básico e reivindicações sociais no município de São Paulo 1974-1984 v1 e v2. São Paulo; 1985 [Tese de Doutorado Faculdade de Filosofia, Letras e Ciências Humanas da USP].

Jordão EP. Gestão Ambiental e Recursos Hídricos. In: Manual de Gestão do Seminário Técnico sobre a gestão de serviços de saneamento; 1999 agosto; Rio de Janeiro, Brasil. Rio de Janeiro: ABES-RJ; 2000. P.III-1 a IV-45.

Judith TF. Estudo sobre o arranjo institucional existente - proposta de um arranjo institucional para o setor de saneamento: recuperação e análise crítica do passado recente e da situação atual. In: Projeto de Modernização do Setor Saneamento USP/Fundação de Apoio à Universidade de São Paulo, INFUB, Núcleo de Pesquisas em Informações Urbanas.

Lefévre F, et all. Recuperando a fala do social. São Paulo (SP); 1998.[Série monográfica, 9 - Faculdade de Saúde Pública].

Libhaber M. Diagnostico del desempeño del sector agua y alcantarillado en Colombia. In: Ministerio de Desarrollo Económico; PNUD; Banco Mundial. Economía del y sector privado. Colombia: Banco Mundial; 1996. p.219-29.

Luna SV. Planejamento de Pesquisa- Uma introdução. São Paulo (SP). Educ. 1998.

Marcon H. Privatização: polêmica. Revista Saneamento Ambiental. 1998; $n^{\circ}$ 51, maio/junho: p.48.

Marcondes MJA. Urbanização e meio ambiente: os mananciais da metrópole paulista. São Paulo;1995.[Tese de Doutorado - Faculdade de Arquitetura e Urbanismo da USP].

Mariano MT. Análise da participação da sociedade civil na gestão dos recursos hídricos no estado de São Paulo. São Carlos; 1996. [Dissertação de Mestrado - Escola Estadual de São Carlos da USP]. 
Martins Junior OP. Uma cidade ecologicamente correta. Goiânia (GO); AB Editora, 1996.

Matus RC. Política, planificacíon e gobierno. Washington; Organizacion Panam de La salud; 1987.

Mello KRC. Transporte urbano de passageiro: as contradições do poder público. São Paulo;1998. [Tese de Doutorado - Faculdade de Filosofia, Letras e Ciências Humanas].

Méndez Espino J. Transicíon de la empresa de aguas de Murcia de una empresa pública a una empresa de economía mixta. In: Ministerio de Desarrollo Económico; PNUD; Banco Mundial. Economía del y sector privado. Bogotá: Banco Mundial; 1996. p.185-98.

Menezes CL. Desenvolvimento urbano e meio ambiente: a experiência de Curitiba. Campinas (SP); Papirus, 1996.

Ministério do Meio Ambiente, dos Recursos Naturais e da Amazônia Legal. Secretaria dos Recursos Hídricos, Associação Brasileira de Ensino Agrícola Superior, UNICEF. Mobilização social. Brasília (DF); 1997.

MPO-Ministério do Planejamento e Orçamento. Secretaria de Política Urbana. Série Modernização do Setor Saneamento. Regulação da prestação de serviços de saneamento - Volume 6. Brasília (DF); 1995.

Mumford L. A cidade na história. São Paulo (SP); Martins Fontes, 1991.

Najar AL, Melamed C. Considerações para análise da política de saneamento no ciclo do Planasa e a formulação de novas diretrizes para o setor. Revista de Administração Municipal. 1990; 37(194):62-76.

Neder RT. Industrialismo e meio ambiente: atores sociais e responsabilidade na crise sócio-ambiental na metrópole de São Paulo. São Paulo; 1993. [Tese de Doutorado - Faculdade de Filosofia, Letras e Ciências Humanas da USP].

Nisman J. La Privatización de los servicios de saneamiento. In: Asociación Argentina de Ingeniería Sanitaria y ciencias del Ambiente: 1996 jun, Buenos Aires, Argentina. p. 128-42.

Oliveira AC. Políticas de meio ambiente no estado de São Paulo 1955/1970: o controle da poluição industrial. São Paulo; 1993. [Dissertação de Mestrado

- Faculdade de Filosofia, Letras e Ciências Humanas da USP].

Pavan RC. Prefeitura desiste da venda do sistema de água e esgoto. Diário Popular 2000 jan. 21.

Philippi Jr A, Maglio JC, Coimbra JAA, Franco RM (editores). Municípios e meio ambiente. Perspectivas para a municipalização da gestão ambiental no Brasil. São Paulo(SP): Associação Nacional de Municípios e Meio Ambiente. 1999.

Ribadeneira $P$. Modelos y politicas sobre el marco legal e institucional del sector agua y saneamiento en la region: Venezuela, Ecuador y Perú. In: 
Reunión Regional sobre Modernizacíon del sector de Agua y saneamiento en América Latina e, Santa Cruz de la Sierra; 1998 Feb 16-19.

Ribeiro CR. A construção de um município saudável: descentralização e intersetoralidade. Saúde e Sociedade. 1997; v.6, nº 2: p.47-53.

Ribeiro H. Do pau-brasil às cidades: considerações sobre as tendências das políticas ambientais no Brasil. Margem. 1997. n.6: p. 6-9.

Ribeiro MA, A crise ambiental urbana brasileira. Revista de Administração Pública. 1992; 26(4): 52-80.

Ruiz A.J. Metodologia científica. Guia para eficiência nos estudos. São Paulo (SP): Atlas, 1976.

SABESP. Companhia de Saneamento Básico do Estado de São Paulo. Revitalização do setor de saneamento. São Paulo (SP); s.d.p.

SABESP. Companhia de Saneamento Básico do Estado de São Paulo. Sabesp. 2000. São Paulo (SP); 2000.

Salvador NNB. Avaliação de impactos sobre a qualidade dos recursos hídricos. São Carlos;1990. [Tese de Doutorado - Escola Estadual de São Carlos da USP].

SANASA-Sociedade de abastecimento de água e saneamento S/A. A água de todo dia. Campinas (SP); 2002.

São Paulo (Estado). Lei n. 9.333, de 27 de dezembro de 1995. Orça a receita e fixa a despesa do Estado para o exercício de 1996. Disponível na página <URL: http://www.planejamento.sp.gov.br> [2001a]

São Paulo (Estado). Lei n. 9.467, de 27 de dezembro de 1996. Orça a receita e fixa a despesa do Estado para o exercício de 1997. Disponível na página <URL: http://www.planejamento.sp.gov.br> [2001b]

São Paulo (Estado). Lei n. 9.902, de 30 de dezembro de 1997. Orça a receita e fixa a despesa do Estado para o exercício de 1998. Disponível na página <URL: http://www.planejamento.sp.gov.br> [2001c]

São Paulo (Estado). Lei n. 10.151, de 29 de dezembro de 1998. Orça a receita e fixa a despesa do Estado para o exercício de 1999. Disponível na página <URL: http://www.planejamento.sp.gov.br> [2001d]

São Paulo (Estado). Lei n. 10.479, de 29 de dezembro de 1999. Orça a receita e fixa a despesa do Estado para o exercício de 2000. Disponível na página <URL: http://www.planejamento.sp.gov.br> [2001e]

Secretaria Estadual do Meio Ambiente. Secretaria Estadual de Recursos Hídricos, Saneamento e Obras. Gestão das Àguas - 6 anos de percurso. São Paulo (SP); 1997.

Semasa-Serviço Municipal de Saneamento Ambiental de Santo André. Semasa saneamento ambiental (caderno institucional) s.d.p. 
Silva ER, Oliveira, MLB. Alternativas de saneamento para pequenas comunidades e médias cidades. Debates Sócio-Ambientais - CEDEC. 1998; $\mathrm{n}^{\circ}$ 08: p.23-24.

Silva SS. Política de meio ambiente no Brasil no início dos anos 90: a construção da cidadania ambiental. São Paulo; 1996.[Dissertação de Mestrado - Faculdade de Filosofia, Letras e Ciências Humanas da USP].

Sobral HR, Silva CA. Balanço sobre a situação do meio ambiente na metrópole de São Paulo. Fundação - SEADE. São Paulo em Perspectiva 1989; 3(4): 7581.

Sobral HR. Do pau-brasil às cidades: considerações sobre as tendências das políticas ambientais no Brasil. Margem: 1997; nº 06: p.93-103.

Sobral HR. O meio ambiente e a cidade de São Paulo. São Paulo (SP); Makron Books, 1996.

Spozati A. Desejo de São Paulo. Novos Estudos - CEBRAP. 1996; 45:183208.

TCE - Tribunal de Contas do Estado de São Paulo. Dados gerais sobre Campinas. exercício de 1998. Disponível na página <URL: http://www.tce.sp.gov.br/siapnet> [2001 Jun 26].

Teixeira EC. Sociedade civil e participação cidadã no poder local; 1998. [Tese de Doutorado - Faculdade de Filosofia, Letras e Ciências Humanas da USP].

Thiollent M. Pesquisas em tempo de eleições In: Boletim Intercom:1982. $\mathrm{n}^{\circ}$ 39;p. 5-7.

Torres OA, Guarch JL. Agua de los andes: de organismo publico a sociedad anonima. In: $9^{\circ}$ Congreso Argentino de Saneamiento y Medio Ambiente. Cordoba, Argentina; 1996. p.208-28.

Vasconcellos, MPC. Os (des)caminhos da formação Sanitária e os direitos sociais: uma reflexão a partir da escola de saúde pública. São Paulo; 2000. [Tese de Doutorado - Faculdade de Saúde Pública da USP].

Wilson R. Cramer, R (1994). International workshop on good local government First Annual Proceedings. Lyndon B. Jonhnson School of Public Affars. UT. Aust. N. Press and Ford. Fountation. 
ANEXO

Modelo de Questionários 


\section{Questionário para os Municípios com Gestão Estadual}

Objetivo do questionário: Identificar a importância dada ao saneamento básico pelos prestadores de serviços de água e esgoto, em seus diversos aspectos sociais, econômicos, ambientais e políticos, bem como identificar as relações e interesses entre Estado e Município na gestão dos sistemas de água e de esgoto.

O período de pesquisa é do ano de 1996 a 2000.

Ano e Mês das respostas:

Nome do Município:

População total do município:

População urbana do município:

População rural do município:

\section{TEMA: ÁGUA}

1. População atendida com água tratada:

2. Extensão de rede de água $(\mathrm{Km})$ :

3. Em que ano foi concedido pelo município os serviços de água?

4. Qual é o prazo de concessão dos serviços de água?

5. No caso do seu município estar com o contrato vencido, qual é a formalização existente?

6. A água bruta a ser tratada para o abastecimento do município é:

( ) $100 \%$ do próprio município? Qual é o volume?

( ) $100 \%$ de outro município, qual? Qual é o volume de água importada?

$\%$ do próprio município, qual é o volume? $\%$ de outro município, qual? Qual é o volume?

7. A água tratada para o abastecimento do município é:

( ) $100 \%$ do próprio município? Qual é o volume?

( ) $100 \%$ de outro município, qual? Qual é o volume? $\%$ do próprio município, qual é o volume? $\%$ de outro município, qual? Qual é o volume?

8. Quantas estações de tratamento de água existem no município?

9. Qual a capacidade de tratamento de cada estação de tratamento?

10. Qual é o tipo de tratamento de água no município? 
11. Qual é o valor do orçamento aplicado anualmente na gestão dos serviços de água no município? Quanto este valor representa em termos percentuais do orçamento da SABESP? Quanto este valor representa em termos percentuais do orçamento da Unidade de Negocio?

12. Quem elege a prioridade para a aplicação dos recursos na gestão dos serviços de água? Quais são os critérios?

13. Qual é a origem dos recursos financeiros utilizados na gestão dos serviços de água no município? Indicar a percentagem de cada uma.

( ) União $\%$

( ) Estado $\%$

( ) Município $\%$

( ) Fonte internacional $\%$ Qual (is), especificar

( ) Outras $\%$ Qual (is), especificar

14. Qual é a percentagem dos recursos financeiros aplicado no sistema de abastecimento de água para:

operação $\%$

manutenção corretiva $\%$

manutenção preventiva $\%$

15. Tem capacitação de pessoal para a gestão dos serviços de água?
( ) $\operatorname{sim}$
( ) não

Se sim, qual é a percentagem dos recursos financeiros aplicado em treinamento? Para o pessoal:

operacional $\%$ administrativo $\%$

gerencial __ $\%$ técnico $\%$

16. O município tem atendimento para reclamações da população em relação aos serviços de água?

17. Quantas reclamações, por parte do usuário, são atendidas por mês?

18. Quais as três principais reclamações efetuadas?

19. Qual é o tempo médio para o atendimento e solução dos problemas reclamados?

20. Qual é a receita dos serviços de água no município?

21. Qual é a despesa operacional para gestão dos serviços de água no município?

22. Qual é o custeio para gestão dos serviços de água no município?

23. A receita proveniente dos serviços de água no município cobre as despesas operacionais e de custeio?
( ) $\operatorname{sim}$
( ) não.

Se não, de onde vem os recursos para cobrir?

24. O orçamento do estado é participativo ? 
( ) sim. ( ) não

Se sim, de que forma?

25. Como o município tem fiscalizado a gestão estadual dos serviços de água ?

26. Existe integração entre estado e município no estabelecimento das políticas públicas para a gestão dos serviços de água?

( ) $\operatorname{sim}$

( ) não

Se sim, de que forma?

27. Comentários e Sugestões

\section{TEMA: ESGOTO}

1. População atendida com rede de esgoto no município:

2. Extensão da rede de esgotos no município $(\mathrm{Km})$ :

3. Em que ano os serviços de esgoto foram concedidos?

4. Qual é o prazo de concessão dos serviços de esgoto?

5. No caso do seu município estar com o contrato vencido, qual é a formalização existente?

6. Qual é o volume de esgoto coletado no município?

7. O esgoto coletado no município é tratado?
( ) $\operatorname{sim}$
( ) não

Se sim, qual é o volume de esgoto tratado?

8. Quantas estações de tratamento de esgoto existem no município?

9. Qual a capacidade de cada estação de tratamento de esgoto?

10. Qual é o tipo de tratamento de esgoto no município?

11. Qual é o orçamento aplicado anualmente na gestão dos serviços de esgoto no município? Quanto este valor representa em termos percentuais do orçamento da SABESP? Quanto este valor representa em termos percentuais do orçamento da Unidade de Negocio?

12. Quem elege a prioridade para a aplicação dos recursos na gestão dos serviços de esgoto?. Quais são os critérios?

13. Qual é a origem dos recursos financeiros utilizados na gestão dos serviços de esgoto no município? Indicar a percentagem de cada uma.
( ) União
$\%$
( ) Estado
$\%$
( ) Município $\%$

( ) Fonte internacional $\%$ Qual (is), especificar

( ) Outras. Qual (is), especificar 
14. Qual é a percentagem dos recursos financeiros aplicados no sistema de esgoto sanitário para:

operação _ _ manutenção corretiva __ $\%$

manutenção preventiva $\%$

15. Tem capacitação de pessoal para a gestão dos serviços de esgoto?
( ) $\operatorname{sim}$
( ) não

16. Se sim, qual é a percentagem dos recursos financeiros aplicados em treinamento? Para o pessoal:

$\begin{array}{ll}\text { operacional } \_\% & \text { administrativo } \\ \text { gerencial } & \%\end{array} \%$

17. O município tem atendimento de ocorrências para população em relação aos serviços de esgoto?

18. Quantas reclamações, por parte do usuário, são atendidas por mês?

19. Quais as três principais reclamações efetuadas?

20. Qual é o tempo médio para o atendimento e solução dos problemas reclamados?

21. Qual é a receita dos serviços de esgoto no município?

22. Qual é a despesa operacional para gestão dos serviços de esgoto no município?

23. Qual é o custeio para gestão dos serviços de esgoto no município?

24. A receita proveniente dos serviços de esgoto no município cobre as despesas operacionais e de custeio?
( ) $\operatorname{sim}$
( ) não.

Se não, de onde vem os recursos para cobrir?

25. O orçamento do estado é participativo ?
( ) sim.
( ) não

Se sim, de que forma?

26. Como o município tem fiscalizado a gestão estadual dos serviços de esgoto?

27. Existe integração entre estado e município no estabelecimento das políticas públicas para a gestão dos serviços de esgoto ?
( ) $\operatorname{sim}$
( ) não

Se sim, de que forma?

28. Comentários e Sugestões 


\section{Questionário para os Municípios com Gestão Municipal}

Objetivo do questionário: Identificar a importância dada ao saneamento básico pelos prestadores de serviços de água, esgoto, em seus diversos aspectos sociais, econômicos, ambientais e políticos, bem como identificar as relações e interesses entre Estado e Município na gestão dos sistemas de água e de esgoto.

O período da pesquisa é do ano de 1996 a 2000.

Ano e Mês das respostas:

Nome do Município:

População total do município:

População urbana do município:

População rural do município:

\section{TEMA: ÁGUA}

1. População atendida com água tratada:

2. Extensão de rede de água $(\mathrm{Km})$ :

3. Qual é o tipo de administração dos serviços de água no município?
( ) adm. direta
( ) adm. indireta

4. Se for adm. direta, é através de:

( ) secretaria municipal ( ) coordenadoria ( ) outros, especificar

5. Se for adm. indireta, qual o tipo?

( ) autarquia ( ) empresa pública ( ) cia de economia mista

( ) fundação ( ) empresa privada ( ) outros, especificar

6. A água bruta a ser tratada para o abastecimento do município é:

( ) $100 \%$ do próprio município? Qual é o volume?

( )100\% de outro município, qual? Qual é o volume de água importada? $\%$ do próprio município. Qual é o volume? $\%$ de outro município, qual município? volume?

7. A água tratada para o abastecimento do município é:

( ) $100 \%$ do próprio município? Qual é o volume?

( )100\% de outro município, qual município?

Qual é o volume? 
\% do próprio município Qual é o volume?

$\%$ de outro município, qual município?

Qual é o volume?

8. Quantas estações de tratamento de água existem no município?

9. Qual a capacidade de cada estação de tratamento de água?

10. Qual é o tipo de tratamento de água utilizado no município?

11. Qual é o valor do orçamento aplicado anualmente na gestão dos serviços de água no município? Quanto este valor representa em termos percentuais do orçamento do município? Quanto este valor representa em termos percentuais do orçamento da Empresa?

12. Quem elege a prioridade para a aplicação dos recursos na gestão dos serviços de água? Quais são os critérios?

13. Qual é a origem dos recursos financeiros utilizados na gestão dos serviços de água no município? Indicar a percentagem de cada uma.
( ) União
( ) Estado $\%$
( ) Município $\%$
( ) Fonte internacional $\%$ Qual (is), especificar

( ) Outras $\%$, Qual (is), especificar

14. Qual é a percentagem dos recursos financeiros aplicados no sistema de abastecimento de água para:

operação $\%$

manutenção corretiva $\%$

manutenção preventiva $\%$

15. Tem capacitação de pessoal para a gestão dos serviços de água?
( ) $\operatorname{sim}$
( ) não

Se sim, qual é a percentagem dos recursos financeiros aplicado em treinamento? Para o pessoal:

$\begin{array}{lll}\text { operacional } & \% & \text { administrativo } \\ \text { gerencial } & \% & \text { técnico }\end{array}$

16. O município tem atendimento para reclamações da população em relação aos serviços de água?

17. Quantas reclamações, por parte do usuário, são atendidas por mês?

18. Quais as três principais reclamações efetuadas?

19. Qual é o tempo médio para o atendimento e solução dos problemas reclamados?

20. Qual é a receita dos serviços de água no município?

21. Qual é a despesa operacional para gestão dos serviços de água no município? 
22. Qual é o custeio para gestão dos serviços de água no município?

23. A receita proveniente dos serviços de água no município cobre as despesas operacionais e de custeio?
( ) $\operatorname{sim}$
( ) não

Se não, de onde vem os recursos para cobrir?

24. O orçamento do município é participativo?
( ) $\operatorname{sim}$
( ) não

Se sim, de que forma?

25. Como é realizado o orçamento participativo em relação a gestão dos serviços de água?

26. Existe integração entre estado e município no estabelecimento das políticas públicas para a gestão dos serviços de água?
( ) $\operatorname{sim}$
( ) não

Se sim, de que forma?

27. Comentários e Sugestões

\section{TEMA: ESGOTO}

1. População atendida com rede de esgoto no município:

2. Extensão da rede de esgotos no município $(\mathrm{Km})$ :

3. Qual a percentagem de esgoto tratado?

4. Qual é o tipo de administração dos serviços de esgoto no município?
( ) adm. direta
( ) adm. indireta

5. Se for adm. direta, é através de:

( ) secretaria municipal ( ) coordenadoria ( ) outros, especificar

6. Se for adm. indireta, qual o tipo?
( ) autarquia ( ) empresa pública ( ) cia de economia mista
( ) fundação ( ) empresa privada
7. Qual é o volume de esgoto coletado no município?
8. O esgoto coletado no município é tratado?
( ) $\operatorname{sim}$
( ) não

Se sim, qual é o volume de esgoto tratado?

9. Quantas estações de tratamento de esgoto existem no município?

10. Qual a capacidade de cada estação de tratamento de esgoto?

11. Qual é o tipo de tratamento de esgoto no município? 
12. Qual é o valor do orçamento aplicado anualmente na gestão dos serviços de esgoto no município? Quanto este valor representa em termos percentuais do orçamento do município? Quanto este valor representa em termos percentuais do orçamento da Empresa?

13. Quem elege a prioridade para a aplicação dos recursos na gestão dos serviços de esgoto? Quais são os critérios?

14. Qual é a origem dos recursos financeiros utilizados na gestão dos serviços de esgoto no município? Indicar a percentagem de cada uma.

( ) União $\%$

( ) Estado $\%$

( ) Município $\%$

( ) Fonte internacional $\%$ Qual (is), especificar

( ) Outras $\%$, Qual (is), especificar

15. Qual é a percentagem dos recursos financeiros aplicados no sistema de esgoto sanitário para:

operação $\%$ manutenção corretiva $\%$

manutenção preventiva $\%$

16. Tem capacitação de pessoal para a gestão dos serviços de esgoto?
( ) $\operatorname{sim}$
( ) não

Se sim, qual é a percentagem dos recursos financeiros aplicados em treinamento? Para o pessoal:

$\begin{array}{ll}\text { operacional __ } \% & \text { administrativo } \\ \text { gerencial __ } \% & \%\end{array}$

17. O município tem atendimento para reclamações da população em relação aos serviços de esgoto?

18. Quantas reclamações, por parte do usuário, são atendidas por mês?

19. Quais as três principais reclamações efetuadas?

20. Qual é o tempo médio para o atendimento e solução dos problemas reclamados?

21. Qual é a receita dos serviços de esgoto no município?

22. Qual é a despesa operacional para gestão dos serviços de esgoto no município?

23. Qual é o custeio para gestão dos serviços de esgoto no município?

24. A receita proveniente dos serviços de esgoto no município cobre as despesas operacionais e de custeio?
( ) $\operatorname{sim}$
( ) não.

Se não, de onde vêm os recursos para cobrir? 
25. O orçamento do município é participativo ?
( ) sim.
( ) não

Se sim, de que forma?

26. Como é realizado o orçamento participativo em relação a gestão dos serviços de esgoto?

27. Existe integração entre estado e município no estabelecimento das políticas públicas para a gestão dos serviços de esgoto ?
( ) $\operatorname{sim}$
( ) não

Se sim, de que forma?

28. Comentários e Sugestões 